\title{
Despre Arhiva veche a Tribunalului județului Lăpușna și despre cele 2345 de documente ale sale din secolele XV-XIX
}

\author{
Petronel Zahariuc ${ }^{\mathrm{A}}$ 욫 \\ Facultatea de Istorie, Universitatea „Alexandru Ioan Cuza”, Bd. Carol I 11, 700506 Iași, România
}

\author{
Despre articol \\ Istoric: \\ Primit 23 aprilie 2020 \\ Acceptat 2 mai 2020 \\ Publicat 10 iunie 2020 \\ Cuvinte-cheie: \\ Moldova \\ Basarabia \\ sate \\ documente medievale \\ documente premoderne
}

\begin{abstract}
Rezumat
La 10 iulie 1926, Prim-Președintele Tribunalului Lăpuşna, judecătorul Eugen Ionescu-Dârzeu, și directorul regional al Arhivelor României, L. T. Boga, au semnat actul de predare-primire a arhivei vechi a Tribunalului Lăpuşna, care cuprindea aproximativ 2345 de documente. La inventariere, L. T. Boga și arhiviștii de la Chișinău au întocmit un opis, care a fost dactilografiat în mai multe exemplare, dintre care unul (exemplarul 3), pe care îl publicăm acum, a ajuns în colecțiile Bibliotecii Academiei Române, probabil din arhiva judecătorului E. Ionescu-Dârzeu. Astăzi, această colecție a fost integrată în Fondul 220 de la Arhivele de la Chișinău. În urma unei priviri de ansamblu asupra documentelor publicate din această arhivă, pot opina că aproximativ un sfert (în jur de 500) au fost editate, mai ales de L.T. Boga și de editorii colecției Moldova în epoca feudalismului, rămînînd pe seama cercetătorilor de acum și din viitor editarea integrală sau în rezumat, tematic sau cronologic, a altor acte din această colecție.

Pînă la împlinirea acestui deziderat, prin editarea critică acestui opis sînt introduse în circuitul științific aproximativ 2000 de documente, chiar dacă sub formă de rezumat. Acest important instrument de lucru arhivistic, cuprinde informații inedite despre istoria Moldovei, mai ales a ținuturilor din stînga Prutului, de dinainte și de după 1812, atît privitoare la istoria politică și socială, cît și la istoria locală, la toponimie sau la genealogie.
\end{abstract}

\section{Introducere}

La 6 iunie 1926, Prim-Președintele Tribunalului Lăpuşna, judecătorul Eugen Ionescu-Dârzeu, a descoperit în podul Palatului de Justiție din Chișinău o comoară, ascunsă „în două lăzi și un geamantan”. Cînd le-a deschis, judecătorul nu a găsit „,cocoșei”, bijuterii sau veșminte prețioase, tăinuite aici de vechea administraţie basarabeană, ci cîteva teancuri de pergamente și hîrtii, bine păstrate, și a înţeles repede, fiind un funcționar diligent, un jurist reputat și un vrednic elev al lui A.D. Xenopol (Toader et al., 2008, p. 131), că a găsit ceva mult mai prețios decît orice alt odor: o parte importantă din arhiva veche a Basarabiei. Cu o indescriptibilă emoție, descoperitorul s-a adresat instituției îndrituite să-i prețuiască comoara: Direcția Regională a Arhivelor Naţionale ale României și directorului ei, L.T. Boga. Directorul Regional al Arhivelor Naționale ale României era, și el, un funcționar zelos, care dorea să pună în practică directivele instituției centrale privitoare la salvgardarea patrimoniului arhivistic din Basarabia, și un arhivist cu experiență, pentru că după unirea Basarabiei cu România se ocupase, cu frumoase rezultate, de organizarea Direcției de Arhivă de la Chișinău (Dascăl, 2017, p. 304-307). Astfel, într-o lună de zile, într-una din camerele Palatului de Justiție, L. T. Boga, ajutat de unul sau doi dintre paleografii de la Arhive, a inventariat conținutul celor două lăzi și a geamantanului, făcînd posibil ca la 10 iulie 1926 să se semneze actul de predare-primire a acestei impresionante colecții de documente istorice, care urma „a se păstra la Direcțiunea Regională a Arhivelor Statului din Chișinău”. Actul a fost dactilografiat în mai multe exemplare,

*Adresă de corespondență: zahariucp@yahoo.com. 
dintre care unul (exemplarul 3), nesemnat, a ajuns în colecțiile Bibliotecii Academiei Române, probabil din arhiva judecătorului E. Ionescu-Dârzeu, fără a putea ști în ce fel a fost achiziționat ${ }^{1}$.

Încă din primul moment, L. T. Boga a înțeles valoarea istorică excepțională a „comorii” și a priceput că i-a ieșit norocul istoriografic în cale! De aceea, vreme de doi ani, arhivistul L. T. Boga a muncit pe brînci pentru a valorifica cît mai mult din această colecție de documente istorice, perfecționîndu-și, în acest scop, cunoștințele de paleografie româno-chirlică, de paleografie slavă și de istorie a românilor, și însuşindu-și tehnica de editare a documentelor românești vechi, scrise în limba slavă sau în limba română cu caractere chirilice. Astfel, începînd cu 1928, în nou-născuta revistă „Arhivele Basarabiei”, dar și în mai bătrîna „Revistă a Societății Istorico-Arheologice Bisericești din Chișinău”, L. T. Boga a publicat, vreme de un deceniu, un șir foarte lung de articole, prin care a îmbrățișat întreaga comoară istoriografică cu care i-a fost dat să se întîlnească. Printre documentele din această colecție, L. T. Boga a presărat și acte scoase din alte colecții păstrate la Arhivele din Chișinău, fără să precizeze, din păcate (deși tehnica de editare de la acea vreme prevedea și acest lucru), fondul sau colecția din care a extrasă fiecare piesă documentară editată. Numai în primul articol (Boga, 1928a, p. I), editorul a făcut necesara mențiune: „o parte din materialul acesta este din bogata depunere făcută la Direcțiunea regională a Arhivelor Statului din Chișinău de dl. Eugen Ionescu-Darzău 〈Dârzeu〉, membru la Curtea de Apel din Chișinău, fericitul descoperitor al documentelor la Tribunalul Lăpușna. Țin, și cu acest prilej, să-i exprim mulțumiri adînci, pentru prețiosul dar făcut istoriei noastre naționale”. După care, doar în alte două rînduri editorul a dat o indicaţie generală: ,aceste documente se află în păstrare la Direcțiunea Regională a Arhivelor Statului Chișinău” (Boga, 1930a, p. 348) sau „mărturiile hotarnice, publicate în acest volum, se află în păstrare la Direcțiunea Regională a Arhivelor Statului din Chișinău, secția istorică” (Boga, 1938a, p. 291).

\section{Cîteva observații asupra editării documentelor din această colecție}

La inventarierea sumară din iunie-iulie 1926, arhiviștii de la Chișinău au înregistrat aproximativ 2345 de documente (mai multe numere se repetă, un document nu a mai fost rezumat, iar 13 numere lipsesc), care se întind din vremea lui Alexandru cel Bun pînă la mijlocul secolului al XIX-lea, cînd limba română a fost înlocuită deplin de limba rusă în administrația Basarabiei (Poștarencu, 2012, p. 113-130). Astfel, aceste acte ,juridice” au devenit documente „istorice”, iar din „vii” s-au transformat în „moarte”, find din fericire păstrate și așteptînd vremea cînd se vor întîlni cu cercetarea istorică. Vremea le-a venit în 1926, iar în prima ladă, L. T. Boga a găsit 1006 documente, iar în lada numărul doi și în geamantan, restul, pînă la 2345. Pe lîngă numerotare, comisia de inventariere a stabilit celelalte rubrici ale registrului („opisului”) inventar: data (anul, luna, ziua), „cuprinderea pe scurt a documentelor” și „observațiuni” (limba, felul actului <original, copie, traducere> și, uneori, numărul de file. Probabil că, într-o primă formă, „opisul” a fost scris de mînă, apoi a fost dactilografiat, astfel că o parte dintre greșelile de scriere, fie ale datei, fie ale unor nume, se datorează și dactilografului, care nu a înțeles scrisul arhivistului. Ca observație generală, pot spune că paleograful care a rezumat aceste documente își cunoștea bine meseria, avînd în vedere termenul foarte scurt, o lună de zile, în care a fost nevoit să prelucreze, chiar așa sumar, colecția de la Tribunalul Lăpușna. Totuși, textul „opisului” cuprinde un număr foarte mare de greșeli (unele datorate dactilografului, cum am presupus mai sus), atît la descifrarea datei și calcularea cronologiei de la Hristos, cît şi la citirea și transcrierea antroponimelor şi toponimelor din documente. Unele dintre aceste greșeli ar fi fost imposibil de corectat, dacă documentele integrale nu ar fi fost editate de L. T. Boga și de colectivele de editori ale colecției Moldova în epoca feudalismului (MEF, I-XII; volumele IX-XII, intitulate și Documente privitoare la istoria Țării Moldovei). În „opisul” pe care îl edităm acum, o parte dintre greșeli, cele mărunte și obișnuite, le-am îndreptat tacit, iar o parte le-am semnalat, punîndu-le între paranteze unghiulare $(\langle\ldots\rangle)$; tot între paranteze unghiulare am pus și completările, pe care le-am făcut pentru o mai bună înțelegere a rezumatului. Pentru identificarea numelor satelor și a ținuturilor din care

${ }^{1}$ BAR, A., nr. 2648. Registru, dactilografiat, 92 p. Pe coperta registrului a fost scris, cu creion albastru: numărul „3” și următorul titlu: „Documente depuse la Arhivele Statului de Tribunalul Lăpuşnei, în 1926. Darzeŭ <Dârzeu>”. 
au făcut parte am folosit o serie de instrumente de lucru, mai vechi (MEF, VII-1,2; Dmitriev, 1973 etc.) sau mai noi (Tomuleț, 2018; Ciobanu et al., 2019, etc.). Acolo unde nu am intuit forma corectă a numelui, fie de persoană, fie de localitate, am pus respectivul cuvînt între ghilimele (,...”), urmînd ca la o eventuală editare a documentului să poată fi corijat și respectivul nume. Arhiviștii au precizat și limba în care au fost redactate documentele; cea mai mare parte sînt scrise în limba română, cu grafie chirilică, apoi în limba slavă, de redacție românească, și în limba rusă, iar mai puține sînt scrise în limbile: greacă, ebraică (sau ivrit), germană, poloneză și franceză. De asemenea, L. T. Boga și colaboratorii săi au precizat felul actului și suportul pe care a fost scris; cea mai mare parte a actelor din această colecție sînt originale, însoțite de copii sau traduceri, însă sînt și multe acte păstrate doar în copie sau în traducere, iar în ceea ce privește materialul de suport a scrisului, colecția cuprinde și un număr însemnat de pergamente.

În aparatul critic am încercat să descopăr dacă documentele au fost publicate de L. T. Boga, A. V. Sava, T.G. Bulat etc., în MEF, în Doc. Ț. Mold. sau în alte ediții de documente. Pentru a nu încărca aparatul critic nu am mai făcut trimitere și la volumele din Documenta Romaniae Historica, seria A, Moldova (DRH), unde documentele cronologic corespunzătoare, însă nu toate, au fost republicate, uneori după documentul păstrat în arhivele de la Chișinău, însă de cele mai multe ori după edițiile oferite de L. T. Boga și de editorii MEF. În urma unei priviri de ansamblu asupra documentelor publicate pînă acum, pot opina că aproximativ un sfert (în jur de 500) au fost editate pînă acum, rămînînd pe seama cercetătorilor de acum și din viitor editarea integrală sau în rezumat, tematic sau cronologic, a altor acte din această colecție.

În Arhivele Statului de la Chișinău (pentru o prezentare generală, vezi Andrieș-Tabac, 2011), această colecție de documente se află astăzi integrată în Fondul 220 (o prezentare generală în Îndrumător, I, p. 235-236). Acest fapt reiese din descrierea arhivistică din MEF, dar mai ales din inventarele acestui Fond (7 inventare în limba rusă și un indice de localități în limba română), fără a fi urmărit dacă absolut toate documentele se regăsesc aici. Cea mai mare parte, însă, fac parte din acest fond. În colecția Achiziții Noi de la Arhivele Naţionale București, unde au ajuns multe documente privitoare la moșii din Basarabia, nu au ajuns și documente din colecția Tribunalului Lăpuşna, și nici în alte depozite arhivistice nu am identificat vreun document, dovadă că „depunerea” din 1926 s-a păstrat în instituția căreia i-a fost încredințată de depunător.

Acum, cîteva cuvinte despre utilitatea publicării „opisului” din 1926. L. T. Boga a editat documente din această colecție, tematic (foi de zestre, „scrisori și răvașe”, „testamente și danii”, mărturii de hotar) şi cronologic („hrisoave”, ispisoace, zapise etc. din secolul al XV-lea pînă la începutul secolului al XIXlea), încercînd și reușind să publice documentele mai interesante și mai răsunătoare din punct de vedere istoriografic. Numai că, în afară de secolul al XV-lea, din care s-au păstrat, oricum, foarte puține documente în această colecție (trei), în urma activității editoriale desfășurată de L. T. Boga, dar și de editorii colecției MEF, au rămas documente inedite din secolele următoare: mai puține din secolul al XVI-lea, dar din ce în ce mai multe, pe măsură ce ne îndreptăm spre 1800. Este adevărat că documentele din secolul al XVIII-lea, fiind mult mai multe decît cele din secolele anterioare, nu numai în această colecție, ci şi în istoria generală a Moldovei de la Carpaţi pînă la Nistru, nu se pot publica integral, ci cronologicselectiv sau tematic. Această observație este nu numai valabilă, dar și obligatorie, pentru documentele din prima jumătate a secolului al XIX-lea. Din această ultimă categorie, unele dintre documentele privitoare la familia Haşdeu și la Tadeu Hașdeu (destul de numeroase în această listă), cred că au fost folosite în studii întocmite de autori din Basarabia, însă descoperirea lor nu este o operațiune facilă, astfel că o las pe seama „viitorului”. Lăsînd la o parte această dificultate, o prezentare generală a acestei colecții, realizată prin editarea acestui „opis”, o consider folositoare, atît pentru întocmirea viitoarelor volume din colecția național-românească de documente interne (DRH), cît și pentru addenda la volumele publicate din DRH și din MEF. De asemenea, o altă observație se cuvine făcută, la care și eu am ajuns doar în urma prelucrării acestui „opis”: documentele publicate de L.T. Boga nu au fost preluate în totalitate în colecția MEF, aşa cum exista credința, ci selectiv (iar, la unele acte, trimiterea la ediția lui L. T. Boga nu a fost făcută), astfel că unele documente nu au mai ajuns în volumele din DRH, în care a existat dorința de a se strînge întreg patrimoniul documentar (intern) românesc din secolul al XIV-lea pînă la mijlocul secolului al XVII-lea. 
Acest fapt duce cu gîndul nu numai la necesitatea păstrării pe masa de lucru a articolelor lui L.T. Boga, ci și, eventual, la adunarea într-un volum a acestor texte, care au fost publicate destul de dezordonat, atît în reviste, cît și în extrase de sine stătătoare, însă cu titluri schimbate.

În ceea ce privește importanța istorică a acestor documente, rezumate în acest „opis”, nu voi insista aici, pentru că ele ar trebui integrate critic în studii privitoare la sate sau la familii boierești sau răzășești, astfel încît să-și poată aduce contribuția la lămurirea unor aspecte mai puțin cunoscute sau la umplerea unor locuri albe din istoria unui sat, a unei familii boierești sau a unui personaj istoric, individual sau colectiv („orheienii”, spre exemplu), etc. Marea majoritate a documentelor din această colecție este privitoare la satele și oamenii din ținuturile: Orhei, Hotin, Lăpuşna, Soroca și Iași (partea cea mai mare din ținutul Iași a fost în stînga Prutului și înainte de 1812). Mai puține documente sînt referitoare la orașele din Moldova (Iași, Chișinău, Hotin), la așezămintele eclesiastice (mănăstirea Căpriana și mănăstirile din Iași: Golia, Trei Ierarhi, Cetățuia), precum și la sate din ținuturile din dreapta Prutului (Dorohoi, Iași).

\section{Concluzii}

Prin publicarea acestui „opis” un număr impresionant de documente intră în circuitul științific, aproximativ două mii, chiar dacă sub formă de rezumat, urmînd ca, la un moment dat, ele să fie editate integral, mai ales acelea care fac parte din Fondul 220 de la Arhivele Statului din Chișinău. Totodată, aceste documente completează zestrea documentară cunoscută privitoare la istoria Moldovei, fiind necesar să fie cuprinse în volumele viitoare din colecția DRH, seria A, Moldova; în vreme ce, acest articol, avind în vedere și faptul că eu sînt unul dintre editorii acestei colecții, poate fi socotit și o addenda la volumele publicate, care conțin documente anterioare anului 1647. Documentele din următoarele două secole, de la mijlocul secolului al XVII-lea pînă la mijlocul secolului al XIX-lea, îmbogățesc numărul de mărturii istorice păstrate pentru aproape fiecare domnie din Moldova, iar cele de după ocuparea Moldovei dintre Prut și Nistru de către Imperiul rus arată, printre altele, păstrarea legăturilor dintre românii din stînga și din dreapta Prutului (vezi și Poștarencu, 2012, p. 248-255; Zahariuc, 2019) și după 1812. Apoi, pentru cercetările de istorie locală, de toponimie și de genealogie, bine reprezentate în ultimele decenii atît la Iași, cît și la Chișinău, cercetătorii pot găsi informații folositoare în „arhiva veche” a Tribunalului Lăpuşna, al cărei „opis”, întocmit în 1926, îl edităm critic acum.

\section{Bibliografie}

\section{A. Surse}

ANB, $A N=$ Arhivele Naționale București, Achiziții Noi.

ANI $D o c .=$ Arhivele Naţionale Iași, Documente.

BAR, $A$. = Biblioteca Academiei Române, Bucureşti, Arhiva.

BAR, Doc. ist. = Biblioteca Academiei Române, București, Documente istorice.

Bezviconi, Gh. (1940). Boierimea Moldovei dintre Prut și Nistru, Actele Comisiei pentru cercetarea documentelor nobilimii din Basarabia, la 1821, vol. I, Fundația Regele Carol I, București.

Bezviconi, Gh. (1943). = Boierimea Moldovei dintre Prut și Nistru. Actele Comisiei pentru cercetarea documentelor nobilimii din Basarabia, la 1821, vol. II, Editura „Fundația Regele Carol I”, București.

Boga, L. T. (1928a). Documente basarabene, I. Foi de zestre (1734-1844), Chișinău.

Boga, L. T. (1928b). Documente basarabene, II. Scrisori și răvaş̧e (1660-1860), Chișinău.

Boga, L. T. (1929a). Documente basarabene, III. Testamente și danii (1672-1858), Tipografia Eparhială „Cartea Românească”, Chișinău.

Boga, L. T. (1929b). Documente basarabene, IV. Hrisoave și cărți domnești (1420-1500), Tipografia Eparhială „Cartea Românească", Chişinău.

Boga, L. T. (1929c). Documente basarabene, V. Hrisoave și cărți domnești (1507-1594), Tipografia Eparhială „Cartea Românească", Chişinău.

Boga, L. T. (1929d). Documente basarabene, VII. Hrisoave și cărți domneşti (1604-1653), Tipografia Eparhială „Cartea Românească", Chișinău.

Boga, L. T. (1929e). Documente basarabene, VIII. Hrisoave și cărțti domnești (1636-16151), Tipografia Eparhială „Cartea Românească”, Chişinău [L.T. Boga, Documente din secolul al XVII-lea (1601-1651), în „Arhivele Basarabiei”, 1 (4)]. 
Boga, L.T. (1929f). Documente din secolul al XVII-lea (1601-1651), în „Arhivele Basarabiei”, 1 (3).

Boga, L. T. (1930a). Documente din secolul al XVIII-lea, în „Arhivele Basarabiei”, 2 (3).

Boga, L. T. (1930b). Documente din secolul al XVIII-lea, în „Arhivele Basarabiei”, 2 (4).

Boga, L. T. (1930c). Documente din secolul al XVII-lea, în „Revista Societății Istorico-Arheologice Bisericești”, 20.

Boga, L. T. (1931a). Documente din Arbivele Basarabiei (1607-1806), Tipografia Eparhială „Cartea Românească”, Chișinău.

Boga, L. T. (1931b). Documente din secolul al XVIII-lea, în „Arhivele Basarabiei”, 3 (2).

Boga, L. T. (1932a). Documente din secolele XVI-XVII, în „Arhivele Basarabiei”, 4 (2).

Boga, L.T. (1932b). Documente basarabene, în „Arhivele Basarabiei”, 4 (4).

Boga, L. T. (1932c). Documente din Basarabia. Zapise (1657-1660), în „Arhivele Basarabiei”, 5 (3).

Boga, L. T. (1933). Documente basarabene, în „Arhivele Basarabiei”, V, nr. 1.

Boga, L. T. (1937a). Documente basarabene, în „Arhivele Basarabiei”, IX, nr. 1.

Boga, L.T. (1937b). Documente basarabene (acte privitoare la moșiile Peresecina, Sămănanca, Camânca, Bezinul, Teleșeu și Cobâlca din județul Orhei), în „Arhivele Basarabiei”, 9 (1-4).

Boga, L. T. (1938a). Documente din Basarabia, II, Tipografia „Dreptatea”, Chișinău.

Boga, L.T. (1938b). Documente basarabene (acte privitoare la Peresecena, Sămănanca, Teleșeu și Cobâlca - județul Orhei), în „Arhivele Basarabiei”, 10 (1-4).

Ciobanu, T., Candu, T. \& Cernenchi, E. (eds) (2019). Populația Țării Moldovei la începutul secolului al XIX-lea. Izvoare fiscale și statistice din anul 1808, vol. I, Editura „Lexon-Prim”, Chişinău.

Doc. Mold. $=$ Documente privind istoria Moldovei sub ocupația militară rusă (1806-1812), vol. întocmit de A. Agachi, I. Varta, V. Constantinov, L. Svetlicinâi, T. Varta, Editura „Litera”, Chișinău, 2012.

Doc. T,.Mold. (2016) = Documente privitoare la istoria Țării Moldovei în perioada războiului ruso-turc din 1806-1812 (noiembrie 1806 - iulie 1808), vol. întocmit de D. Dragnev, L. Svetlicinâi, T. Candu, T. Ciobanu, V. Constantinov, Editura „Tehnica-Info", Chișinău.

Doc. T..Mold. $(2017)$ = Documente privitoare la istoria Țării Moldovei în perioada războiului ruso-turc (august 1808 - iunie 1809), vol. întocmit de D. Dragnev, L. Svetlicinâi, T. Candu, T. Ciobanu, Editura Academiei Române și Editura „Istros”, București/Brăila.

Doc. T,.Mold., IX = Documente privitoare la istoria Țärii Moldovei în secolul al XVIII-lea (1751-1774) [Moldova în epoca feudalismului, vol. IX], vol. întocmit de L. Svetlicinâi, D. Dragnev, E. Bociarov, Editura „Civitas”, Chișinău, 2004.

Doc. Ț.Mold., X = Documente privitoare la istoria Țării Moldovei în secolul al XVIII-lea (1775-1786) [Moldova în epoca feudalismului, vol. X], vol. întocmit de L. Svetlicinâi, D. Dragnev, E. Bociarov, Editura „Civitas”, Chișinău, 2005.

Doc. T,.Mold., XI = Documente privitoare la istoria Țării Moldovei în secolul al XVIII-lea (1787-1800) [Moldova în epoca feudalismului, vol. XI], vol. întocmit de L. Svetlicinâi, D. Dragnev, E. Bociarov, Editura „CEP USM”, Chișinău, 2008.

Doc. T,.Mold., XII = Documente privitoare la istoria Țării Moldovei în secolul al XVIII-lea (1801-1806) [Moldova în epoca feudalismului, vol. XII], vol. întocmit de Larisa Svetlicinâi, Demir Dragnev, Eugenia Bociarov, Chișinău, 2012.

Îndrumător, I = Îndrumător al Arbivelor Naționale a Republicii Moldova (partea 1, până la anul 1917, ediția a doua revăzută și completată), Chișinău, 2004.

MEF, I = Moldova în epoca feudalismului (veacul XVI-întâiul pătrar al veacului XVII), vol. întocmit de P. G. Dmitriev, D. M. Dragnev, E. M. Rusev, P. V. Sovetov, Editura „Știința”, Chișinău, 1961.

MEF, II = Moldova în epoca feudalismului (veacul XVI-întâiul pătrar al veacului XVII), vol. întocmit de D. M. Dragnev, A. N. Nichitici, L. I. Svetlicinaia, P. V. Sovetov, Editura „Știința”, Chișinău, 1978.

MEF, III = Moldova în epoca feudalismului (1601-1640), vol. întocmit de D. M. Dragnev, A. N. Nichitici, L. I. Svetlicinaia, P. V. Sovetov, Editura „Știința”, Chișinău, 1982.

MEF, IV = Moldova în epoca feudalismului (1641-1660), vol. întocmit de D. M. Dragnev, A. N. Nichitici, L. I. Svetlicinaia, P. V. Sovetov, Editura „Știința”, Chișinău, 1986.

MEF, V = Moldova în epoca feudalismului (1661-1670), vol. întocmit de D. M. Dragnev, A. N. Nichitici, L. I. Svetlicinaia, P. V. Sovetov, Editura „Știința”, Chișinău, 1987.

MEF, VI = Moldova în epoca feudalismului (1671-1710), vol. întocmit de A. N. Nichitici, D. M. Dragnev, L. I. Svetlicinaia, P. V. Sovetov, Editura „Știința”, Chișinău, 1992.

MEF, VII-1 = Moldova în epoca feudalismului. Recensămintele populaţiei Moldovei din anii 1772-1773 și 1774, vol. întocmit de P. G. Dmitriev, Editura „Știința”, Chișinău, 1987.

MEF, VII-2 = Moldova în epoca feudalismului. Recensămintele populației Moldovei din anii 1772-1773 și 1774, vol. întocmit de P. G. Dmitriev, Editura „Știința”, Chișinău, 1987.

MEF, VIII = Moldova în epoca feudalismului. Documente moldovenești din secolul al XVIII-lea (1711-1750), vol. întocmit de L. Svetlicinâi, D. Dragnev, E. Bociarov, Chișinău, 1998.

Sava, A. V. (1937). Documente privitoare la târgul și ținutul Lăpușnei, Editura „Fundația Carol I”, București.

Sava, A.V. (1944). Documente privitoare la târgul și ținutul Orheiului, București. 


\section{B. Lucrări de referință}

Andrieș-Tabac, S. (2011). Istoricul Arbivelor Republicii Moldova, în M. Taşcă (ed.), Ghidul Arbivelor din Republica Moldova, Editura „Pontos”, Chișinău, p. 12-19.

Arbore, Z. (1904). Dicționarul geografic al Basarabiei, București.

Bacalov, S. (2015). Neamul de boieri lăpușneni Cărăbăț/Darie: istorie și genealogie, în Lăpușna. Studii de istorie și genealogie, editori: G. Postică, T. Candu, Editura „Masterprint SRL”, Chișinău, p. 102-126.

Bacumenco, L. (2006). Ținutul Orheiului inn secolele XV-XVI, Editura Universităţii „Alexandru Ioan Cuza”, Iași.

Berechet, Șt. (1928). Mănăstirea Căpriana, Tipografia Eparhială "Cartea Românească”, Chișinău.

Bezviconi, G., (1992). Profiluri de ieri și de azi, în Fapte trecute și basarabeni uitați, Editura „Universitas”, Chișinău, p. 5-233.

Candu, T. (2014a). Văsieni, Manoileşti, Fânaru: file de istorie, Editura „ARC”, Chişinău.

Candu, T. (2014b). Considerații privind originea și evoluția familiei Plămădeală: ramura läpuşneană a lui Simion Plămădeală in secolele XVII-XVIII, în „Studii de arhondologie și genealogie”, 2, p. 194-200.

Candu, T. (2016). O „istorie” a satelor Bardar și Ruseștii Noi in secolele XVII-XVIII. Hotarnica moșiei Dulejeni de pe Botna de la 1803, în „Anuarul Institutului de Istorie”, p. 28-88.

Constantinov, V. (2014). Din istoria unei plastografii. Judecata lui Tadeu Hâjdeu cu Arghire Cuza și Iordache Millo pentru jumătate din satul Rujavența, ținutul Hotin, din anul 1820, în „Studii de arhondologie și genealogie”, 2, p. 208-220.

Constantinov, V. \& Ciobanu, T. (2017). O spiță de neam și noi documente cu privire la istoria neamului Hâjdeu, în „Studii de arhondologie și genealogie", 4, p. 43-59.

Costăchescu, M. (1930). Satul și târgul Telinești din județul Orhei. Schiță istorică, Editura „Institutului de Arte Grafice «Viața Românească»", Iaşi.

Dascăl, O (2017). Leonida Boga: arbivistul, „macedoneanul”, „voshopoleanlu”, în „Archiva Moldavix”, 9, p. 299-338.

Dmitriev, P. G. (1973). Народнонаселение Молдавии (по материалам переписей 1772-1773, 1774 и 1803 г2.), Chișinău.

Duminică, I. (2015). Incercarea boierilor Ciolacoglo de a obține noblețea în Basarabia, în „Studii de arhondologie și genealogie”, 3, p. 124-141.

Eremia, A. (2002-2003). Note de toponimie basarabeană, în „Dacoromania”, 7-8, p. 171-175.

Eșanu, A., Eșanu, V., Fuștei, N., Pelin, V. \& Negrei, I. (eds) (2003). Mănăstirea Căpriana (sec. XV-XX). Studiu istoric, documente, cărți, inscripții și alte materiale, Editura „Pontos”, Chişinău.

Gonța, A. (1990). Documente privind istoria României A. Moldova, veacurile XIV-XVII (1384-1625), Indicele numelor de locuri, ediție de I. Caproșu, Editura Academiei Române, București.

Grămadă, N. (1996). Toponimia minoră a Bucovinei, I-II, ediție de I. Popescu-Sireteanu și D. Vatamaniuc, Editura „Anima”, Centrul de Studii „Bucovina”.

Gumenâi, I. (2002). Istoria ținutului Hotin de la origini până la 1806, Editura „Civitas”, Chișinău.

Iorga, N. (1912). Din ținuturile pierdute. Boieri și răzeși în Bucovina și Basarabia în cele dintâi decenii după anexare, București. Iorga, N. (1920). Lucruri nouă găsite în Basarabia, în „Revista Istorică”, 6 (3-6), p. 69-95.

Lapedatu, Al. (1916). Documente și lămuriri istorice cu privire la desfacerea proprietăților moldovene de peste Prut după pierderea Basarabiei (16/28 mai 1812 - 2/14 ianuarie 1814), București.

Mutruc, V. (2003). Cu privire la evoluția proprietății funciare in Basarabia in prima jumătate a secolului al XIX-lea, în In memoriam professoris Mihail Muntean, editori: V. Tomuleț, I. Șarov, I. Ojog, A. Zanoci, Editura „Cartdidact”, Chișinău, p. 114-136.

Nicu, V. (1991). Localitățile Moldovei in documente și cărți vechi. Îndreptar bibliografic, I-II, Editura „Universitas”, Chișinău.

Onea, O. (1994). Genealogia familiei Hasdeu alcătuită de Tadeu Petriceicu Hasdeu, în „Arhiva Genealogică”, 6 (3-4), p. 83-101.

Poștarencu, D. (2012). Destinul românilor basarabeni sub ocupație țaristă, Chișinău.

Poștarencu, D. (2013). Neamul de nobili Demi din Basarabia, în S. Bacalov (coord.), Studii de arhondologie și genealogie, 1, p. 112-118.

Poștarencu, D. (2015). Neamul Donică-Iordăchescu. Ramura vel căpitanului Macarie, în „Studii de arhondologie și genealogie”, 3, p. 111-119.

Rosetti, R. (1909). Arbiva Senatorilor din Chișinău și ocupația rusească de la 1806 la 1812, III (Amănunte asupra Moldovei de la 1808 la 1812), București.

Toader, T., Mâț̆ă, D. C. \& Costea, I.M. (2008). Dicţionarul personalităților juridice românești, Editura „Hamangiu”, București.

Tomuleț, V. (2014), Basarabia în epoca modernă (1812-1918). Instituții, regulamente, termeni, ediția a II-a, revăzută și adăugită, Editura „Lexon-Prim”, Chişinău.

Tomuleț, V. (2018). Ținutul Hotin in surse statistice rusẹsti din prima jumătate a secolului al XIX-lea, Editura „Lexon-Prim”, Chișinău.

Zahariuc, P. (2019). Despre desfacerea proprietăților din Moldova după pacea de la București (1812). Cîteva adăugiri, în „Diacronia", 9, 7 mai, art. A130, Crossref.

Zahariuc, P. \& Marinescu, F. (2008). O manifestare neobservată a moștenirii bizantine in diplomatica medieval moldovenească și câteva note despre biserica mănăstirii Golia, în De la Iași la Muntele Athos, Studii și documente de istorie a Bisericii, Editura Universității „Alexandru Ioan Cuza”, Iași, p. 9-30. 


\section{Anexa A. BAR, $A$., nr. 2648. Registru, dactilografiat, 92 p.}

Opisul documentelor depuse spre păstrare la Direcțiunea Regională a Arhivelor Statului din Chișinău de Tribunalul județului Lăpușna

\begin{tabular}{|c|c|c|c|c|c|}
\hline No. & Anul & Luna & Ziua & Cuprinderea pe scurt a documentelor & Observațiuni \\
\hline 1 & 1772 & iulie & 4 & $\begin{array}{l}\text { Moșii ce are la ținutul Hotinului Ioniță Strâșca biv } \\
\text { vel căpitan }\end{array}$ & românesc \\
\hline 2 & 1819 & iunie & 30 & $\begin{array}{l}\text { Jalba lui Zaharia Bulat, Vasile Bulat etc. adresată } \\
\text { consulului rusesc, Andrei Pizani, de la Iași }\end{array}$ & ” \\
\hline 3 & 1836 & noiembrie & 9 & $\begin{array}{l}\text { Opis de documentele Bulateștilor pentru moșia } \\
\text { Pocșăști }\end{array}$ & $\begin{array}{l}\text { cuprinde } 16 \\
\text { (șasesprezece file) }\end{array}$ \\
\hline 4 & & & & $\begin{array}{l}\text { Caiet cu diverse documente, în traducere rusească, } \\
\text { privitoare la moșia Bulateștilor (Pocsăști). Între ele, } \\
\text { copia în românește a averii Bulateștilor adresată } \\
\text { Divanului (1810 iunie } 25)\end{array}$ & \\
\hline 5 & 1819 & octombrie & 2 & $\begin{array}{l}\text { Jalba răzeşilor moșiei Pocsăști, ținutul Orhei, către } \\
\text { Înaltul Sfat al Basarabiei }\end{array}$ & $\begin{array}{l}\text { românesc, cu o trad. } \\
\text { rusească }\end{array}$ \\
\hline 6 & 1775 & iunie & 20 & $\begin{array}{l}\text { Cartea lui Grigorie Ghica voievod în pricina de } \\
\text { judecată pentru moșia <Cobăești }{ }^{2}\end{array}$ & $\begin{array}{l}\text { copie românească, cu o } \\
\text { trad. rusească }\end{array}$ \\
\hline 7 & 1817 & martie & 20 & $\begin{array}{l}\text { Scrisoarea lui Ioan căminar către Teodor „,Tambali” } \\
\text { în diverse chestiuni negustorești }\end{array}$ & $\begin{array}{l}\text { orig. grecesc, cu o } \\
\text { traducere românească }\end{array}$ \\
\hline 8 & 1812 & ianuarie & 20 & $\begin{array}{l}\text { Carte de desfacere a tovărășiei negustorești între } \\
\text { Gheorghie Meleli și Anastasie Ciolac }\end{array}$ & $\begin{array}{l}\text { rusesc, cu traducere } \\
\text { românească }\end{array}$ \\
\hline 9 & - & - & - & $\begin{array}{l}\text { Opisul documentelor, aparținînd lui Anastasie } \\
\text { Ciolac }\end{array}$ & rusesc \\
\hline 10 & 1814 & ianuarie & 14 & Notiță de veniturile anului 1814 & $\begin{array}{l}\text { grecesc, cu trad. } \\
\text { românească }\end{array}$ \\
\hline 11 & 1821 & martie & 15 & $\begin{array}{l}\text { Scrisoarea lui Teodor „T, Tambali” către Anastasie } \\
\text { Ciolac }\end{array}$ & $\begin{array}{l}\text { grecesc, cu trad. } \\
\text { românească }\end{array}$ \\
\hline 12 & 1811 & martie & 20 & $\begin{array}{l}\text { Declarația lui Gheorghe Meleli privitoare la } \\
\text { veniturile moșiei Drăgănești }\end{array}$ & idem \\
\hline 13 & 1822 & iulie & 7 & Chitanța lui Dinu $<$ Rusu $\rangle^{3}$ pentru 3.250 ruble & românesc \\
\hline 14 & 1822 & iulie & 13 & Idem, pentru 8.325 ruble & ” \\
\hline 15 & 1822 & august & 11 & Idem, pentru 1.510 ruble & ” \\
\hline 16 & 1822 & septembrie & 20 & Idem, pentru 1.000 ruble & ” \\
\hline 17 & 1825 & aprilie & 10 & Idem, pentru 2.000 ruble & ” \\
\hline 18 & - & - & - & Opisul scrisorilor pameșcicului Enache Rusul & ” \\
\hline 19 & 1824 & iunie & 3 & $\begin{array}{l}\text { Chitanța de primire a } 4.500 \text { ruble de Judecătoria } \\
\text { ținutului }\end{array}$ & rusesc \\
\hline 20 & 1822 & iulie & 18 & Chitanța lui F. Rusu pentru 2.000 ruble & românesc \\
\hline 21 & 1822 & iulie & 21 & Idem, pentru 271 lei & " \\
\hline 22 & 1822 & iulie & 7 & Idem, pentru 7.000 ruble & ” \\
\hline 23 & 1822 & august & 9 & Chitanța lui F. Rusu pentru 1.000 lei & ” \\
\hline 24 & 1822 & septembrie & 1 & Idem, pentru 920 ruble & ” \\
\hline 25 & 1822 & iulie & 3 & $\begin{array}{l}\text { Chitanța lui F. Rusu de banii ce a primit de la Ioan } \\
\text { Pruncu }\end{array}$ & ” \\
\hline 26 & 1822 & iulie & 14 & $\begin{array}{l}\text { Chitanța lui F. Rusu de banii ce a primit de la Ioan } \\
\text { Pruncu }\end{array}$ & ” \\
\hline 27 & 1822 & mai & 15 & $\begin{array}{l}\text { Vechilimeaua dată de Enacachi Rusul lui Panait } \\
\text { Cazimir }\end{array}$ & ” \\
\hline 28 & 1826 & iunie & 2 & $\begin{array}{l}\text { Socoteala slujbei goștinii anului } 1822 \text { a țănuturilor } \\
\text { Orheiului și Hotinului }\end{array}$ & ” \\
\hline
\end{tabular}

2̂̂n text: „Cobușești”.

'În text: „Roni”. 


\begin{tabular}{|c|c|c|c|c|c|}
\hline 29 & - & - & - & Opisul seneturilor pameșcicului Enacachi Rusu & $"$ \\
\hline 30 & 1824 & mai & 13 & $\begin{array}{l}\text { Adresa Isprăvniciei ținutului Orhei către } \\
\text { caznaceistva }^{4} \text { ținutului }\end{array}$ & ” \\
\hline 31 & 1822 & iulie & 14 & Chitanța lui E.Rusu pentru 21.000 lei & 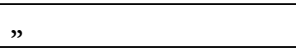 \\
\hline 32 & 1822 & iulie & 1 & Idem, pentru 14.000 lei & ” \\
\hline 33 & 1825 & noiembrie & 18 & Idem, pentru 7.630 & ” \\
\hline 34 & 1823 & februarie & 14 & Idem, pentru 500 lei & 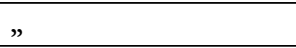 \\
\hline 35 & 1823 & ianuarie & 10 & Idem, pentru 500 lei & 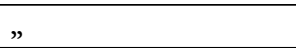 \\
\hline 36 & 1822 & septembrie & 20 & Idem, pentru 3.000 ruble & 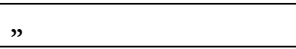 \\
\hline 37 & 1822 & iulie & 29 & Idem, pentru 4.325 ruble & 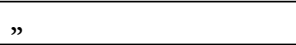 \\
\hline 38 & $\begin{array}{l}7258 \\
1749\end{array}$ & decembrie & 9 & 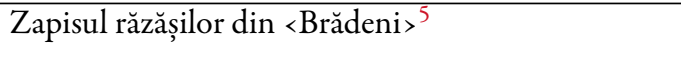 & " \\
\hline 39 & 1834 & noiembrie & 21 & Mărturia dată de boierii Sturzești & 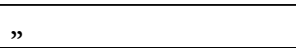 \\
\hline 40 & 1834 & octombrie & 30 & $\begin{array}{l}\text { Certificatul, dat de Sfatul Administrativ al } \\
\text { Moldovei, lui D. Sturdza }\end{array}$ & ” \\
\hline 41 & - & - & - & opisul documentelor Sturzești & rusesc \\
\hline 42 & 1836 & iunie & 15 & $\begin{array}{l}\text { Contract provizoriu de vînzarea moșiei Demideni, } \\
\text { din județul Hotin, a lui Clucerescul }\end{array}$ & ” \\
\hline 43 & 1792 & - & - & Dania părintelui protosinghel Venedict ${ }^{6}$ & $\begin{array}{l}\text { copie și traducerea } \\
\text { rusească }\end{array}$ \\
\hline 44 & 1817 & iulie & 13 & $\begin{array}{l}\text { Mărturia locuitorilor din satul „Mănceni” } \\
\text { privitoare la moșia „Mănceni”" }\end{array}$ & $\begin{array}{l}\text { românesc și traducere } \\
\text { rusească }\end{array}$ \\
\hline 45 & - & - & - & Spița neamului protosinghelului Venedict & românesc \\
\hline 46 & 1817 & decembrie & 14 & $\begin{array}{l}\text { Adeverința lui Alexandru Nicolau pentru venitul } \\
\text { moșiei Gura Buhotinului }\end{array}$ & românesc, copie \\
\hline 47 & 1823 & aprilie & 19 & $\begin{array}{l}\text { Cartea lui I. }<\text { Sturza }>^{8} \text { voievod, dată boierului } \\
\text { Răducanu Roseti, spre a merge în Bucovina }\end{array}$ & ” \\
\hline 48 & - & - & - & $\begin{array}{l}\text { Socoteală între boierii Ioan Balș și hatmanul } \\
\text { Răducanu Roseti }\end{array}$ & ” \\
\hline 49 & 1821 & ianuarie & 9 & Scrisoarea lui <Ion > Balș ${ }^{9}$ & 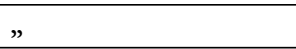 \\
\hline 50 & 1813 & decembrie & 2 & $\begin{array}{l}\text { Chitanța hatmanului Roseti pentru două mii } \\
\text { galbeni }\end{array}$ & $”$ \\
\hline 51 & 1828 & septembrie & 7 & $\begin{array}{l}\text { Izvod de păgubirile suferite de Răducanu Roset din } \\
\text { neplata datoriilor de către Ioan Balș }\end{array}$ & ” \\
\hline 52 & 1817 & noiembrie & 13 & $\begin{array}{l}\text { Contractul încheiat între Marcu jidovul și } \\
\text { Răducanu Roset }\end{array}$ & ” \\
\hline 53 & 1828 & septembrie & 19 & Idem & $\#$ \\
\hline 54 & 1817 & iulie & 3 & Scrisoarea lui Ioan Balș către $<$ hatmanul Roset $>^{10}$ & românesc \\
\hline 55 & 1822 & septembrie & 19 & Idem $^{11}$ & ” \\
\hline 56 & - & - & - & Idem $^{12}$ & 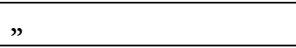 \\
\hline 57 & 1823 & februarie & 23 & Idem $^{13}$ & ” \\
\hline 58 & - & - & - & $\begin{array}{l}\text { Notița făcută de Vasile Danu privitoare la niște } \\
\text { datorii }\end{array}$ & ” \\
\hline
\end{tabular}

${ }^{4}$ "trezorerie”.

5în text: „Orădeni (?)” (MEF, VIII, p. 214-215, nr. 174).

${ }^{6}$ Boga (1929a), p. 23-24, nr. XV.

${ }^{7}$ Probabil: „Mănești”.

${ }^{8}$ În text, greșit: „Suțu”.

${ }^{9}$ Boga (1928b), p. 69, nr. LXXXV.

${ }^{10}$ Așa în text, însă numele destinatarului nu apare în text, ci doar numele soției sale, „cucoana Eufrosina”; Boga (1928b), p. 39, nr. XLV.

${ }^{11}$ Boga (1928b), p. 85, nr. CVIII (la fel, destinatarul nu este menționat, ci doar soția sa).

${ }^{12}$ Această scrisoare ar putea fi cea din 22 septembrie 1822, adresată de logofătul Balş lui Manolache Negruți; Boga (1928b), p. 85 , nr. CIX.

${ }^{13}$ Boga (1928b), p. 90-91, nr. CXVI. 


\begin{tabular}{|c|c|c|c|c|c|}
\hline 59 & 1817 & iulie & 17 & Scrisoarea lui Ioan Balș ${ }^{14}$ & ” \\
\hline 60 & 1829 & august & 8 & Scrisoarea lui Spiridon Pavlu & grecească \\
\hline 61 & 1829 & octombrie & 31 & Scrisoarea căminarului Spiridon Pavlu & $\begin{array}{l}\text { grecească cu trad. } \\
\text { românească }\end{array}$ \\
\hline 62 & 1816 & februarie & 1 & $\begin{array}{l}\text { Scrisoarea de vechilime, dată de Răducanu Roseti, } \\
\text { lui I. Săvescul }\end{array}$ & românesc \\
\hline 63 & 1827 & octombrie & 7 & $\begin{array}{l}\text { Scrisoarea lui Alexandru Balș < către tatăl său, } \\
\text { „babaca”> } 15\end{array}$ & ” \\
\hline 64 & 1818 & iunie & 5 & Chitanța lui Spiridon Pavli de 800 galbeni & grecească \\
\hline 65 & 1818 & aprilie & 24 & Idem, pentru 1.000 galbeni & ” \\
\hline 66 & 1819 & noiembrie & 10 & Idem, pentru 270 galbeni & " \\
\hline 67 & 1819 & mai & 17 & Idem, pentru 400 galbeni & ” \\
\hline 68 & 1819 & martie & 15 & Idem, pentru 750 galbeni & ” \\
\hline 69 & 1816 & noiembrie & 11 & Idem, pentru 1.000 galbeni & ” \\
\hline 70 & 1816 & decembrie & 15 & Idem, pentru 1.000 galbeni & ” \\
\hline 71 & 1818 & iulie & 6 & Idem, pentru 510 galbeni & ” \\
\hline 72 & 1818 & iunie & 21 & Idem, pentru 2.000 galbeni & ” \\
\hline 73 & 1819 & mai & 23 & Idem, pentru 200 galbeni & ” \\
\hline 74 & 1819 & iulie & 16 & Idem, pentru 120 galbeni & ” \\
\hline 75 & 1818 & august & 1 & Idem, pentru 600 galbeni & ” \\
\hline 76 & 1818 & august & 10 & Idem, pentru 185 galbeni & ” \\
\hline 77 & 1818 & noiembrie & 11 & Idem, pentru 500 galbeni & ” \\
\hline 78 & 1818 & noiembrie & 27 & Idem, pentru 500 galbeni & ” \\
\hline 79 & 1816 & decembrie & 29 & Idem, pentru 240 galbeni & ” \\
\hline 80 & 1828 & septembrie & 1 & $\begin{array}{l}\text { Contract încheiat către Ion Petrovici și Raducanu } \\
\text { Roset }\end{array}$ & românesc (copie) \\
\hline 81 & 1820 & mai & 1 & $\begin{array}{l}\text { Chitanța de lei } 60.000 \text { dată de Ecaterina Raducanu } \\
\text { Roseti }\end{array}$ & românesc \\
\hline 82 & 1816 & mai & 1 & Idem & ” \\
\hline 83 & 1817 & mai & 1 & Idem & 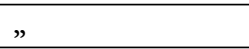 \\
\hline 84 & 1817 & septembrie & 18 & Idem, pentru 67.000 lei & ” \\
\hline 85 & 1815 & februarie & 12 & Idem, pentru 2,820 galbeni & " \\
\hline 86 & 1817 & noiembrie & 25 & Idem, pentru 240 galbeni & ” \\
\hline 87 & 1816 & ianuarie & 13 & Idem, pentru 240 galbeni & ” \\
\hline 88 & 1814 & decembrie & 2 & Idem, pentru 2.240 galbeni & \# \\
\hline 89 & - & - & - & Douăzeci chitanțe de la Răducanu Roset & ” \\
\hline 90 & 1811 & aprilie & 16 & Spița neamului Clucerescu & ” \\
\hline 91 & 1825 & ianuarie & 25 & Foaie de zestre dată $\left\langle\right.$ de $>{ }^{16}$ Grigoraș Istrate & ” \\
\hline 92 & 1816 & octombrie & 26 & $\begin{array}{l}\text { Foaie de zestre dotală a lui Grigoraș Istrate < pentru } \\
\text { fiica sa, Catrina }>17\end{array}$ & $"$ \\
\hline 93 & 1806 & iunie & 2 & $\begin{array}{l}\text { Cartea de judecată, dată de Divanul Moldovei, în } \\
\text { pricina dintre Ioan Volcinschi și Macarie Donică }{ }^{18}\end{array}$ & ” \\
\hline 94 & 1836 & martie & 3 & Declarația Marioarei Palade și a spătarului Milo & $\begin{array}{l}\text { românesc, cu trad. } \\
\text { rusească }\end{array}$ \\
\hline 95 & 1821 & martie & 21 & Mărturia răzeșilor din Durlești & românesc \\
\hline 96 & 1836 & martie & 14 & $\begin{array}{l}\text { Vechilimeaua dată de Maria Paladi și Grigore Milo } \\
\text { generalului Sterov }\end{array}$ & $\begin{array}{l}\text { românesc, cu trad. } \\
\text { rusească }\end{array}$ \\
\hline 97 & 1835 & octombrie & 7 & $\begin{array}{l}\text { Actul de }\left\langle\text { cesiune }>^{19} \text { a lui Constantin Râșcanu a }\right. \\
\text { unei bucăți de pămînt orașului Chișinău }\end{array}$ & rusesc \\
\hline
\end{tabular}

${ }^{14}$ Boga (1928b), p. 38, nr. XLIV (cu data de zi: „16”).

${ }^{15}$ Boga (1928b), p. 119, nr. CLVIII (cu data de zi: „7”).

${ }^{16}$ În text: „lui”.

${ }^{17}$ Boga (1928a), p. 25-26, nr. XVII.

${ }^{18}$ Doc. T. Mold., XII, p. 353-360, nr. 357 (text după original din „fondul personal Demir Dragnev”). Pentru Macarie Donică, vezi Poștarencu (2015, p. 111).

${ }^{19}$ În text: „oniune”. 


\begin{tabular}{|c|c|c|c|c|c|}
\hline 98 & 1859 & octombrie & & $\begin{array}{l}\text { Act cu diverse copii în pricina răzeșilor „Sușnală” } \\
\text { (în } 20 \text { file) }\end{array}$ & rusești \\
\hline 99 & 1834 & octombrie & 30 & $\begin{array}{l}\text { Copie după încheierea Tribunalului ținutului } \\
\text { Hotin în pricina lui I. Cazimir }\end{array}$ & rusesc \\
\hline 100 & 1821 & august & 2 & $\begin{array}{l}\text { Jalba lui Gheorghe Proca către pămînteasca } \\
\text { Isprăvnicie a Hotinului }\end{array}$ & românesc \\
\hline 101 & - & - & - & Spița neamului Vasilie vatavu & ” \\
\hline 102 & - & - & - & Spița neamului din moșia Tuzora & ” \\
\hline 103 & - & - & - & Spița neamului Drăgan & 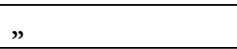 \\
\hline 104 & 1801 & februarie & 20 & Spița neamului Vlas & ” \\
\hline 105 & - & - & - & Spița neamului Tuzoreanu & ” \\
\hline 106 & - & - & - & Spița neamului „Frainşa” & 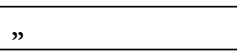 \\
\hline 107 & - & - & - & $\begin{array}{l}\text { Caiet cu mai multe acte românești și traduceri } \\
\text { rusești, în } 24 \text { foi }\end{array}$ & " \\
\hline 108 & 1811 & aprilie & 21 & $\begin{array}{l}\text { Ordin de la Părcalabia Hotinului pentru moșia } \\
\text { Volcinețul și altele }\end{array}$ & ” \\
\hline 109 & $\frac{7258}{1749}$ & decembrie & 9 & $\begin{array}{l}\text { Caiet de așezare a neamului Apapie, din ținutul } \\
\text { Iașilor }\end{array}$ & ” \\
\hline 110 & 1825 & iunie & 26 & Mărturia hotarnică a răzășilor din moșia „Tamile”20 & $"$ \\
\hline 111 & $\begin{array}{l}1731 \\
<7240>\end{array}$ & septembrie & 21 & $\begin{array}{l}\text { Cartea lui Grigorie Ghica voievod dată lui Bărgan } \\
\text { din Brădeni }\end{array}$ & " \\
\hline 112 & 1746 & iulie & 10 & $\begin{array}{l}\text { Cartea logofătului către aprodul Agapie } \\
<\text { Sapsafir }>22\end{array}$ & ” \\
\hline 113 & 1860 & mai & 23 & $\begin{array}{l}\text { Scrisoarea lui Ioan Emandi <și a lui A. Scorețescu > } \\
\text { către E. Soroceanu }\end{array}$ & " \\
\hline 114 & 1677 & octombrie & 20 & $\begin{array}{l}\text { Cartea pîrcălabului de Hotin în pricina lui } \\
<\text { Andronic Badiul }>24\end{array}$ & românesc, copie \\
\hline 115 & 1772 & septembrie & 13 & $\begin{array}{l}\text { Cartea de la Logofeția cea Mare în pricina lui } \\
\text { Grigorie vameșul }\end{array}$ & românesc \\
\hline 116 & 1811 & mai & 15 & $\begin{array}{l}\text { Cartea Divanului Moldovei către stolnicul Ioan } \\
\text { Cheșcu }\end{array}$ & românesc, copie \\
\hline 117 & $\frac{7258}{1749}$ & decembrie & 9 & $\begin{array}{l}\text { Zapisul lui <Enachie }>^{25} \text { Bărgan de vînzarea unor } \\
\text { părți din moșia Brădeni (Iași })^{26}\end{array}$ & " \\
\hline 118 & $\frac{7254}{1746}$ & martie & 18 & $\begin{array}{l}\text { Cartea lui Nicolae voievod dată feciorilor lui } \\
\text { Apostol Bărgan }\end{array}$ & " \\
\hline 119 & $\frac{7249}{1741}$ & martie & 18 & $\begin{array}{l}\text { Cartea lui Grigorie Ghica voievod, dată < Aniței, } \\
\text { fiica lui Lupu vistiernic, surorii ei, soția lui Enache } \\
\text { vistiernic, și fraților ei, Iordache căpitan și } \\
\text { Filipoțchie }{ }^{28}\end{array}$ & ” \\
\hline 120 & 1807 & august & 25 & $\begin{array}{l}\text { Zapisul răzeșilor din Ciuluc pentru vînzarea unor } \\
\text { părți din moșie }\end{array}$ & românesc (copie) \\
\hline 121 & 1802 & mai & 8 & $\begin{array}{l}\text { Cartea lui Alexandru Nicolae Suțul voievod pentru } \\
\text { cercetarea hotarelor moșiilor Dumbrăveni și } \\
<\text { Brădeni }{ }^{29}\end{array}$ & românesc \\
\hline 122 & 1815 & mai & 5 & $\begin{array}{l}\text { Contract de cumpărare de la Constantin Palade a } \\
\text { venitului moșiilor „Nicești” și „Cucoșii” }\end{array}$ & ” \\
\hline
\end{tabular}

\footnotetext{
${ }^{20}$ Poate „Tochile”.

${ }^{21}$ Boga (1930a), p. 362-363, nr. XVII.

${ }^{22}$ În text: „Saftafir”. Pentru acest nume, vezi MEF, VIII, p. 215, nr. 174.

${ }^{23}$ Boga (1928b), p. 148, nr. CCIV

${ }^{24}$ În text, greșit: „Andronică Radul”. Boga (1938b), p. 32-35, nr. XII (mărturie hotarnică).

${ }^{25}$ În text, greșit: „Gurachie”.

${ }^{26}$ MEF, VIII, p. 216-217, nr. 175 (zapsiul nu este de vînzare, ci de împărțire).

${ }^{27}$ Boga (1931b), p. 206-208, nr. XXX.

${ }^{28}$ În text, greșit: „familiei Filipoțchi”. Boga (1931b), p. 209, nr. XXVIII; MEF, VIII, p. 163-166, nr. 128.

${ }^{29}$ În text: „Rădoaia”.
} 


\begin{tabular}{|c|c|c|c|c|c|}
\hline 123 & 1811 & august & 9 & $\begin{array}{l}\text { Porunca Divanului Cnejiei Moldovei către } \\
\text { ispravnicii ținutului Soroca }\end{array}$ & " \\
\hline 124 & 1808 & iulie & 15 & $\begin{array}{l}\text { Porunca Divanului Cnejiei Moldovei, dată lui D. } \\
\text { Sturza, pentru moșia Cucoșii }\end{array}$ & $"$ \\
\hline 125 & 1801 & noiembrie & 11 & $\begin{array}{l}\text { Cartea lui Alexandru Nicoale Suțul voievod, dată } \\
\text { lui C. Paladi biv vel vornic, pentru moșia } \\
\text { Dumbrăveni }\end{array}$ & " \\
\hline 126 & 1800 & iunie & 20 & Hotărîrea moșeiei Brădeni & ” \\
\hline 127 & 1828 & februarie & 1 & $\begin{array}{l}\text { Întărirea domnească pe zapisul de vînzare al } \\
\text { „Trofimei” Micleasca }\end{array}$ & $"$ \\
\hline 128 & $\frac{7125}{1617}$ & ianuarie & 12 & $\begin{array}{l}\text { Cartea domnului Radu Mihnea voievod dată } \\
\text { mănăstirii Căpriana. Danie }{ }^{30}\end{array}$ & $\begin{array}{l}\text { slovenesc, pergament, și } \\
\text { suret moldovenesc }\end{array}$ \\
\hline 129 & $\frac{7136}{1627}$ & octombrie & 30 & $\begin{array}{l}\text { Cartea lui Miron Barnovschi Movilă voievod dată } \\
\text { mănăstirii Căpriana }\end{array}$ & $\begin{array}{l}\text { slovenesc pe hîrtie } \\
\text { deteriorată, cu suret } \\
\text { moldovenesc și trad. } \\
\text { rusească }\end{array}$ \\
\hline 130 & $\frac{7138}{1629}$ & decembrie & 5 & $\begin{array}{l}\text { Cartea lui Alexandru voievod dată mănăstrii } \\
\text { Capriana (deteriorată) }\end{array}$ & $\begin{array}{l}\text { slovenesc, deteriorat, } \\
\text { traducere } \\
\text { moldovenească şi } \\
\text { rusească }\end{array}$ \\
\hline 131 & $\frac{7258}{1750}$ & iunie & 25 & $\begin{array}{l}\text { Cartea lui Constantin Mihail Cehan Racoviță } \\
\text { voievod dată mănăstirii Căpriana }\end{array}$ & românesc, trad. rusească \\
\hline 132 & $\frac{7170}{1662}$ & ianuarie & 16 & $\begin{array}{l}\text { Cartea lui Istrate Dabija voievod dată mănăstirii } \\
\text { Capriana }^{31}\end{array}$ & $\begin{array}{l}\text { slovenesc, cu trad. } \\
\text { rusească }\end{array}$ \\
\hline 133 & 1783 & iunie & 16 & $\begin{array}{l}\text { Cartea lui Alexandru Constantin voievod, dată lui } \\
\text { Mihai Mutul din Pașcani }\end{array}$ & $\begin{array}{l}\text { românesc, cu trad. } \\
\text { rusească }\end{array}$ \\
\hline 134 & $\frac{7212}{1704}$ & ianuarie & 13 & $\begin{array}{l}\text { Cartea lui Mihai Racoviță voievod dată mănăstirii } \\
\text { Căpriana }\end{array}$ & $\begin{array}{l}\text { românesc, cu trad. } \\
\text { rusească }\end{array}$ \\
\hline 135 & $\frac{7142}{1634}$ & februarie & 3 & $\begin{array}{l}\text { Cartea lui Moise Movilă voievod dată lui Tăutul } \\
\text { logofăt }\end{array}$ & $\begin{array}{l}\text { slovenesc, cu trad. } \\
\text { moldovenească }\end{array}$ \\
\hline 136 & $\frac{7143}{1635}$ & august & 24 & Cartea lui Vasilie voievod dată lui Tăutul logofăt & $\begin{array}{l}\text { slovenesc, cu suret } \\
\text { moldovenesc }\end{array}$ \\
\hline 137 & $\frac{7154}{1646}$ & august & 12 & Cartea lui Vasile voievod dată lui Ștefan logofătul & românesc \\
\hline 138 & $\frac{7224}{1716}$ & - & - & $\begin{array}{l}\text { Zapisul lui Constantin, fiul lui Scarlat, pentru satul } \\
\text { Mihulenii }\end{array}$ & $\begin{array}{l}\text { românesc, deteriorat, } \\
\text { trad. rusească }\end{array}$ \\
\hline 139 & 1782 & iunie & 5 & $\begin{array}{l}\text { Carte de la boierii Cnejiei Moldovei, dată } \\
\text { praporcicului Ivașcu }<\text { Gugea }>^{32} \text { din satul } \\
<\text { Lipiceni, din ținutul Orhei }>^{33}\end{array}$ & $\begin{array}{l}\text { românesc, cu trad. } \\
\text { rusească }\end{array}$ \\
\hline 140 & 1788 & iunie & 24 & $\begin{array}{l}\text { Cartea lui Constantin Moruzi voievod, dată lui } \\
\text { Ivașcu }<\text { Gagea }>^{34} \text {, pentru moșia Lipcani }\end{array}$ & $\begin{array}{l}\text { românesc, cu trad. } \\
\text { rusească }\end{array}$ \\
\hline 141 & $\frac{7003}{1495}$ & februarie & 5 & $\begin{array}{l}\text { Hrisovul lui Ștefan voievod prin care întărește } \\
\text { vînzarea moșiei Rezina, făcută de <Donea, fiica }> \\
\text { Nastei }^{35}\end{array}$ & $\begin{array}{l}\text { slovenesc, pergament cu } \\
\text { pecete atîrnată, cu o } \\
\text { trad. rusească }\end{array}$ \\
\hline 142 & $\frac{7084}{1576}$ & - & - & $\begin{array}{l}\text { Hrisovul lui Petre voievod, dat lui <Bratco, Voanța } \\
\text { și altora }>^{36} \text {, prin care îi întărește o cumpărătură la } \\
\text { Rezina }^{37}\end{array}$ & $\begin{array}{l}\text { slovenesc, cu trad. } \\
\text { rusească }\end{array}$ \\
\hline
\end{tabular}

\footnotetext{
${ }^{30} \mathrm{MEF}, \mathrm{I}, \mathrm{p} .310-313$, nr. 138.

${ }^{31}$ Berechet (1928), p. 16-17, nr. III; Eșanu et al. (2003), p. 160-161, nr. 11 (text după Berechet, 1928).

${ }^{32}$ În text: „Gagea”.

${ }^{33}$ În text: „Lipcani”; pentru forma corectă a numelor, vezi Sava (1944), p. 185, nr. 192 (document din 15 aprilie 1724).

${ }^{34}$ În text: „Guge”. Nu știu care este forma corectă a numelui, nemaintâlnindu-l în documentele vremii.

${ }^{35}$ MEF, II, p. 207-212, nr. 66; și alte ediții după documentul din Arhiva de la Chișinău.

${ }^{36}$ În text: „Vratco, Ivanița”.

${ }^{37}$ Boga (1929c), p. 27-28, nr. XX.
} 


\begin{tabular}{|c|c|c|c|c|c|}
\hline 143 & $\frac{7126}{1618}$ & mai & 8 & $\begin{array}{l}\text { Cartea lui Radul voievod, dată lui Eremia Băseanul, } \\
\text { pentru moșia Rezina }\end{array}$ & $\begin{array}{l}\text { slovenesc, cu trad. } \\
\text { rusească }\end{array}$ \\
\hline 144 & $\frac{7127}{1619}$ & iunie & 8 & $\begin{array}{l}\text { Cartea lui Gaspar voievod, dată lui Băseanul, } \\
\text { pentru satul Rezina }\end{array}$ & $\begin{array}{l}\text { slovenesc, cu trad. } \\
\text { rusească }\end{array}$ \\
\hline 145 & $\frac{7177}{1669}$ & iulie & 20 & $\begin{array}{l}\text { Cartea lui Iliaș Alexandru voievod, dată lui Ilie și } \\
\text { surorii sale, Cerna, pentru satul Rezina }\end{array}$ & romănesc \\
\hline 146 & $\frac{7221}{1712}$ & decembrie & 7 & $\begin{array}{l}\text { Zapisul lui Ioniță, feciorul lui Gavril, pentru satul } \\
\text { Rezina }\end{array}$ & românesc, cu trad. rus. \\
\hline 147 & $\frac{7246}{1738}$ & iulie & 12 & $\begin{array}{l}\text { Cartea lui Grigorie Ghica voievod, dată lui Ion } \\
\text { „Cozin” } 38 \text {, pentru moșia „Sfapina” }\end{array}$ & ” \\
\hline 148 & $\frac{7259}{1751}$ & mai & 19 & $\begin{array}{l}\text { Zapisul lui Toader Cuza pentru vînzarea moșiei } \\
\text { „Șofrănești” }\end{array}$ & ” \\
\hline 149 & $\frac{7260}{1752}$ & ianuarie & 10 & $\begin{array}{l}\text { Zapisul Tofanei Botez pentru schimbul făcut cu } \\
\text { Dumitrașcu Cuze }\end{array}$ & ” \\
\hline 150 & $\frac{7260}{1752}$ & iulie & 1 & Însemnările, pe unde sînt hotarele moșiei Răzina & ", \\
\hline 151 & $\frac{7260}{1761}$ & noiembrie & 1 & $\begin{array}{l}\text { Zapisul lui Teodor Cuze prin care mărturisește că a } \\
\text { luat } 30 \text { lei de la Iordache Cantacuzino }\end{array}$ & ” \\
\hline 152 & $\frac{7274}{1766}$ & iulie & 2 & $\begin{array}{l}\text { Zapisul lui Andrei Cotruță prin care vinde moșia } \\
<\text { Stohnaia, din ținutul Orhei }{ }^{39} \text {, lui Iordache } \\
\text { Cantacuzino }\end{array}$ & ” \\
\hline 153 & - & - & - & $\begin{array}{l}\text { Zapisul lui Gheorghe din }<\text { Stohnaia }>\text { prin care } \\
\text { vinde partea lui din moșia }<\text { Stohnaia }>\text { lui Ion } \\
\text { Răuleț }\end{array}$ & ” \\
\hline 154 & - & - & - & $\begin{array}{l}\text { Zapisul Aftemiei prin care vinde moșia sa din } \\
\text { Stoicani, <din ținutul Soroca > }\end{array}$ & " \\
\hline 155 & - & - & - & $\begin{array}{l}\text { Zapisul lui „Caisău” }{ }^{40} \text { prin care vinde moșia sa din } \\
\text { Stoicani }\end{array}$ & " \\
\hline 156 & - & - & - & $\begin{array}{l}\text { Zapisul lui Tanase prin care vinde moșia sa din } \\
\text { Stoicani }\end{array}$ & ” \\
\hline 157 & $\frac{7127}{1619}$ & ianuarie & 9 & $\begin{array}{l}\text { Cartea lui Radu voievod, dată mănăstirii Galata, } \\
\text { prin care îi dăruește satul Udrinești, ținutul Orheiu }\end{array}$ & $\begin{array}{l}\text { slovenesc, cu trad. } \\
\text { românească și rusească } \\
\text { și un extras românesc }\end{array}$ \\
\hline 158 & $\frac{7217}{1709}$ & iunie & 12 & $\begin{array}{l}\text { Zapisul lui Constantin Scarlat prin care vinde 1/2 } \\
\text { din satul Udrești }\end{array}$ & $\begin{array}{l}\text { românesc, cu } \\
\text { trad.rusească }\end{array}$ \\
\hline 159 & $\frac{7224}{1716}$ & iulie & 18 & $\begin{array}{l}\text { Zapisul lui Constantin Scarlat prin care vinde 1/2 } \\
\text { din satul Udrești }\end{array}$ & " \\
\hline 160 & $\frac{7224}{1716}$ & iulie & 20 & $\begin{array}{l}\text { Cartea lui Ghedeon arhiepiscopul și mitropolitul } \\
\text { Sucevei prin care întărește vînzarea lui Scarlat }\end{array}$ & ” \\
\hline 161 & $\frac{7235}{1726}$ & septembrie & 27 & $\begin{array}{l}\text { Zapisul lui Toader Paladi vel paharnic prin care } \\
\text { vinde satul Viteleuca }\end{array}$ & " \\
\hline 162 & 1775 & noiembrie & 25 & $\begin{array}{l}\text { Cartea lui Grigorie Ghica voievod, cu hotărîrea în } \\
\text { pricina moșiei Ciorna, din ținutul Soroca }\end{array}$ & " \\
\hline 163 & 1786 & iulie & 10 & $\begin{array}{l}\text { Cartea lui Grigorie Ghica voievod, cu hotărîrea în } \\
\text { chestia vînzării moșiei Ciorna }\end{array}$ & ” \\
\hline 164 & 1807 & octombrie & 25 & $\begin{array}{l}\text { Ravaș de la Logofeția cea Mare în chestia moșiei } \\
\text { Ciorna }\end{array}$ & ” \\
\hline 165 & 1807 & iulie & 22 & $\begin{array}{l}\text { Zapisul lui Pavăl Filip prin care vinde o parte din } \\
\text { moșia Rezina }\end{array}$ & " \\
\hline 166 & 1807 & decembrie & 22 & $\begin{array}{l}\text { Zapisul lui Filip prin care vinde o parte din moșia } \\
\text { Rezina }\end{array}$ & " \\
\hline 167 & 1808 & - & - & Cartea Logofeției în pricina vînzării moșiei Rezina & $"$ \\
\hline
\end{tabular}

\footnotetext{
${ }^{38}$ Poate „Cuza”.

${ }^{39}$ În text: „Stobnaia”, iar în rezumatul următor: „Stocnaia/Stacnaia”.

${ }^{40}$ Poate „Caisin”.
} 


\begin{tabular}{|c|c|c|c|c|c|}
\hline 168 & 1776 & aprilie & 22 & $\begin{array}{l}\text { Cartea lui Grigorie Ghica voievod pentru moșia } \\
\text { Udrești, din ținutul Orheiu }\end{array}$ & $"$ \\
\hline 169 & 1864 & august & 25 & $\begin{array}{l}\text { Chitanța lui Gheorghe Rășcanu de primirea a } 25 \\
\text { lei, arvonă }\end{array}$ & $"$ \\
\hline 170 & 1868 & ianuarie & 24 & $\begin{array}{l}\text { Chitanța lui Vasile Canacrati pentru primirea unor } \\
\text { acte. }\end{array}$ & grecesc. \\
\hline 171 & 1867 & noiembrie & 23 & Zapisul de zestre a lui „Pahrovschi, dat fiicei sale. & rusesc \\
\hline 172 & 1813 & martie & 23 & $\begin{array}{l}\text { Hotărîrea Sărdăriei Orheiului în pricina lui } \\
\text { Alexandru Larion de la „Clupeneni” }\end{array}$ & românesc, cu trad. rus. \\
\hline 173 & 1837 & aprilie & 24 & $\begin{array}{l}\text { Hotărîrea răzeșilor de moșie din satul Peciștea, < din } \\
\text { ținutul Orhei>, cu privire la niște pămînturi din } \\
\text { acea moșie }^{41}\end{array}$ & românesc \\
\hline 174 & 1847 & aprilie & 23 & $\begin{array}{l}\text { Contract de vînzare a unei case din Folești, făcut de } \\
\text { Zeilic Rozenblut }\end{array}$ & rusesc \\
\hline 175 & 1864 & august & 5 & Șase scrisori poloneze ale lui Alexandru Hajdău & - \\
\hline 176 & 1858 & iunie & & Contract de arendare a moșiei Scumpia & rusesc \\
\hline 177 & 1857 & octombrie & 24 & Act de vînzare al moșiei Gorodiște & ” \\
\hline 178 & 1867 & februarie & 13 & Scrisoarea lui Rusanov către F. Stefanovici & ” \\
\hline 179 & 1865 & ianuarie & 30 & $\begin{array}{l}\text { Cinci scrisori ale lui Grigore Stavilă către cneazul } \\
\text { Mihail Alexandrovici }\end{array}$ & " \\
\hline 180 & 1867 & octombrie & 5 & Act de danie al lui Șmil Averbuch & $\begin{array}{l}\text { evreiesc, cu trad. } \\
\text { rusească }\end{array}$ \\
\hline 181 & 1864 & aprilie & 14 & Contract de cumpărare a satului $<$ Răzăleni ${ }^{42}$ & rusesc \\
\hline 182 & 1864 & iunie & 2 & $\begin{array}{l}\text { Chitanța de primire a } 1.000 \text { lei de către Elena } \\
\text { Antonovna de la Covaco }\end{array}$ & $"$ \\
\hline 183 & 1860 & iunie & 30 & Chitanța lui Andrei Gherș pentru 750 ruble & ” \\
\hline 184 & 1866 & mai & 30 & $\begin{array}{l}\text { Zapis de vînzare al răzășilor din comuna } \\
\text { „Schuluceni” } 43\end{array}$ & " \\
\hline 185 & 1857 & decembrie & 5 & $\begin{array}{l}\text { Chitanța de primire a } 4.500 \text { ruble de Gheorghe } \\
\text { Costachi }\end{array}$ & ” \\
\hline 186 & 1866 & septembrie & 20 & $\begin{array}{l}\text { Chitanța de primire a arvunei pentru vînzarea unei } \\
\text { bucăți de pămînt din Mitoc }\end{array}$ & ” \\
\hline 187 & 1850 & decembrie & 11 & $\begin{array}{l}\text { Contract de vînzare a } 100 \text { chile grîu de către } \\
\text { Pulcheria Mano }\end{array}$ & ” \\
\hline 188 & 1857 & - & - & Patru chitanțe iscălite de Pulcheria Mano & " \\
\hline 189 & 1858 & ianuarie & 1 & $\begin{array}{l}\text { Act de danie al lui Ilie Botezat pentru vărul său, } \\
\text { Dumitrache Lefter }{ }^{44}\end{array}$ & românesc, cu trad. rus. \\
\hline 190 & - & - & - & Două foi evreiești & \\
\hline 191 & 1829 & noiembrie & - & $\begin{array}{l}\text { Certificat dat de cetățenii din Cetatea-Albă văduvei } \\
\text { Cabascova }\end{array}$ & rusesc \\
\hline 192 & 1836 & februarie & 22 & $\begin{array}{l}\text { Contractul lui Ioan Cojevnicov pentru construirea } \\
\text { unei case la Cetatea-Albă }\end{array}$ & $”$ \\
\hline 193 & 1857 & mai & 17 & Contract de închiriere a unei case din Cetatea-Albă & ” \\
\hline 194 & 1880 & martie & - & Planul moșiei Salcea & ” \\
\hline 195 & 1854 & februarie & 3 & $\begin{array}{l}\text { Contract de arendare a cîtorva prăvălii din comuna } \\
\text { Alexandreni }\end{array}$ & " \\
\hline 196 & 1857 & - & - & $\begin{array}{l}\text { Caiet de opt acte, în copii, însoțite de notițe, ale lui } \\
\text { Alexandru Hajdău. }\end{array}$ & rusește \\
\hline 197 & 1822 & aprilie & 11 & $\begin{array}{l}\text { Izvod de zestre al lui Alexandru Șeptelici, dat fiicei } \\
\text { sale, Elena }\end{array}$ & în 3 copii \\
\hline 198 & 1827 & octombrie & 26 & $\begin{array}{l}\text { Copie după hotărîrea Judecătoriei ținutului Hotin } \\
\text { în pricina lui Tudorache Gheorghiu }\end{array}$ & rusesc \\
\hline
\end{tabular}

\footnotetext{
${ }^{41}$ Pentru toponimul „Peciște”, vezi Eremia (2002-2003), p. 173.

${ }^{42}$ În text: „Rezelina”.

${ }^{43}$ Poate „Suruceni”.

${ }^{44}$ Boga (1929a), p. 79-82, nr. XLIX.
} 


\begin{tabular}{|c|c|c|c|c|c|}
\hline 199 & 1827 & aprilie & 11 & Idem & ” \\
\hline 200 & 1774 & iulie & 4 & $\begin{array}{l}\text { Cartea arhiepiscopului Gavriil pentru găsirea } \\
\text { hotarelor moșiilor Petroasa, <Bocanii }{ }^{45} \text { și Socii, } \\
<\text { din ținutul Iași }{ }^{46}\end{array}$ & românesc \\
\hline 201 & 1775 & mai & 10 & $\begin{array}{l}\text { Cartea lui Grigorie Ghica voievod în pricina de } \\
\text { judecată pentru satul Măgura <a lui Vasile Carp } \\
\text { cu }>{ }^{47} \text { Andronache Doltul }{ }^{48}\end{array}$ & ” \\
\hline 202 & 1767 & august & 6 & $\begin{array}{l}\text { Cartea lui Grigorie Ghica voievod, dată lui Toader } \\
\text { Buhăescul, pentru satele Bocanii și Socii }\end{array}$ & " \\
\hline 203 & 1767 & mai & 27 & $\begin{array}{l}\text { Cartea de judecată a Divanului Moldovei în pricina } \\
\text { satului Măgura }\end{array}$ & " \\
\hline 204 & 1777 & mai & 31 & $\begin{array}{l}\text { Jalba răzăşilor moșiei Brădeni către Departamentul } \\
\text { al 2-lea al oblastiei Basarabia }\end{array}$ & ” \\
\hline 205 & 1773 & august & 3 & $\begin{array}{l}\text { Porunca lui < Alexandru Rimski-Korsakov> }>^{49} \text { în } \\
\text { pricina satelor din ținutul Hotinului, aparținînd lui } \\
\text { Ioniță Strâșca }\end{array}$ & în copie, românesc \\
\hline 206 & 1816 & septembrie & 13 & $\begin{array}{l}\text { Zapisul lui Erhan de vînzare a unei părți de moșie } \\
\text { din „Galați” }\end{array}$ & $\begin{array}{l}\text { românesc, cu trad. } \\
\text { rusească }\end{array}$ \\
\hline 207 & 1815 & mai & 28 & $\begin{array}{l}\text { Adeverință dată lui Silvestru că este răzeș al moșiei } \\
\text { Onișcani }\end{array}$ & ” \\
\hline 208 & 1817 & decembrie & - & Spița familiei < răzeșilor din> Brădeni & românesc \\
\hline 209 & - & - & - & Spița familiei < răzeșilor din> Sperja & " \\
\hline 210 & 1812 & aprilie & 12 & Spița neamului lui Ștefan clucer & ” \\
\hline 211 & 1858 & februarie & 2 & $\begin{array}{l}\text { Actul de danie al mitropolitului „Nicandru” pentru } \\
\text { sora sa }\end{array}$ & rusesc \\
\hline 212 & 1860 & iunie & 3 & Contracte de închiriere & ” \\
\hline 213 & 1865 & ianuarie & 7 & $\begin{array}{l}\text { Scrisoarea lui Bercu „Pitchis” către Feodor } \\
\text { Nicolaevici }\end{array}$ & " \\
\hline 214 & 1867 & martie & & $\begin{array}{l}\text { Act de vînzare al unei mori, făcut de Gherș Meer } \\
\text { Leib }\end{array}$ & ” \\
\hline 215 & 1868 & ianuarie & 11 & Chitanța arhimadritului Sofronie pentru 258 ruble & " \\
\hline 216 & 1866 & octombrie & 13 & $\begin{array}{l}\text { Adeverință dată de orășenii din Cetatea-Albă lui } \\
\text { Uscaduros }\end{array}$ & " \\
\hline 217 & 1867 & februarie & 26 & $\begin{array}{l}\text { Scrisoarea lui Bogoliubov către Constantin } \\
\text { Franțovici. }\end{array}$ & ” \\
\hline 218 & 1869 & iunie & 3 & $\begin{array}{l}\text { Certificat dat de orășenii din orașul Bălți lui Meer } \\
\text { „Bronzan” }\end{array}$ & ” \\
\hline 219 & 1869 & ianuarie & 8 & Copia jurnalului Judecătoriei ținutului Orhei & " \\
\hline 220 & 1860 & decembrie & 17 & $\begin{array}{l}\text { Contract dat de Zahar Achimov pentru serviciul ce } \\
\text { se obligă a-l face lui Socolov }\end{array}$ & ” \\
\hline 221 & 1861 & iulie & 9 & Scrisoarea lui Albotă către Mih. Livovici & ” \\
\hline 222 & 1853 & septembrie & 28 & Socoteala dijmei de la viile din Purcari & ” \\
\hline 223 & - & - & - & $\begin{array}{l}\text { Actul încheiat de arbitrii lui Iosif „Morucovici” }{ }^{0} \\
\text { cu Feiga „Martcovei” }\end{array}$ & evreiesc \\
\hline 224 & 1855 & iulie & 4 & $\begin{array}{l}\text { Copie după hotărîrea Judecătoriei ținutului } \\
\text { Chișinău în chestia lui Olșevschi }\end{array}$ & rusesc \\
\hline 225 & 1835 & august & 28 & Copie după recensămîntul lui Ioan Soroceanu & ” \\
\hline 226 & 1855 & decembrie & 21 & Scrisoarea lui Olșevschi către Nicolae Vichentievici & " \\
\hline 227 & 1868 & aprilie & 8 & Jalba lui Soroceanu către Judecătoria ținutală & ” \\
\hline
\end{tabular}

\footnotetext{
${ }^{45}$ În text: „Socanii”.

${ }^{46}$ Doc. T. Mold., IX, p. 242, nr. 212.

${ }^{47}$ În text: „Nicu”.

${ }^{48}$ Doc. T. Mold., X, p. 25-26, nr. 5.

${ }^{49}$ În text: „Alex. Biruschi Cersalov”.

${ }^{50}$ Probabil: „Moscovici”.
} 


\begin{tabular}{|c|c|c|c|c|c|}
\hline 228 & 1858 & august & 18 & $\begin{array}{l}\text { Vichilemeaua data de ieromonahul Feofan lui } \\
\text { Chiril Pavlovici }\end{array}$ & $"$ \\
\hline 229 & 1858 & septembrie & 12 & Extras din cartea notarului din Iampol & 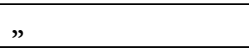 \\
\hline 230 & 1819 & ianuarieie & 11 & Contract încheiat de Dobrințov pentru casă & ” \\
\hline 231 & 1859 & februarie & 20 & Scrisoarea Varvarei Starova către Groisman & ” \\
\hline 232 & 1791 & iulie & 14 & $\begin{array}{l}\text { Zapisul de vînzare al Bărgăneștilor pentru moșia } \\
\text { Brădeni }\end{array}$ & românesc \\
\hline 233 & - & august & 2 & $\begin{array}{l}\text { Zapisul părcălabului de Hotin, Gheorghe, pentru } \\
\text { vînzarea unei părți de moșie din Dumeni }\end{array}$ & $\begin{array}{l}\text { slovenesc, cu trad. } \\
\text { românească }\end{array}$ \\
\hline 234 & $\frac{1711}{1636}$ & mai & 21 & $\begin{array}{l}\text { Mărturia lui Dumitrașco șoltuzul pentru vînzarea } \\
\text { unui loc în Hotin }\end{array}$ & $"$ \\
\hline 235 & $\frac{7144}{1636}$ & martie & 16 & $\begin{array}{l}\text { Cartea lui Vasilie voievod, dată lui Pătrașco } \\
\text { Danovici, <pentru> vînzarea unei părți din moșia } \\
\text { Dumeni, <ținutul Hotin> }{ }^{51}\end{array}$ & ” \\
\hline 236 & 1811 & octombrie & 15 & $\begin{array}{l}\text { Hotărîrea moșiilor < Costiceni și Dumeni, din } \\
\text { ținutul Hotin, făcută de banul Andronache } \\
\text { Donici }>52\end{array}$ & românesc \\
\hline 237 & 1811 & decembrie & 13 & $\begin{array}{l}\text { Hotărîrea Divanului Moldovei în pricina moșiei } \\
\text { Costiceni }\end{array}$ & ” \\
\hline 238 & $\frac{7151}{1642}$ & octombrie & 19 & $\begin{array}{l}\text { Cartea <lui Vasile voievod în pricina dintre } \\
\text { Andronic Badiul, ginerele Grapinei, fiica lui } \\
\text { Gânscă, și Gheroghiță Prăjescu, pentru o parte din } \\
\text { satul Cerlina, ținutul Hotin > } 53\end{array}$ & copie, românesc \\
\hline 239 & 1811 & octombrie & 10 & $\begin{array}{l}\text { Mărturia răzeșilor moșiei Cerlina privitoare la } \\
\text { hotărnicirea moșiei }\end{array}$ & românesc \\
\hline 240 & 1814 & septembrie & 3 & $\begin{array}{l}\text { Cartea departamentului al 11-lea dată în pricina } \\
\text { postelnicului Iordache Vărnav }\end{array}$ & copie, românesc \\
\hline 241 & - & - & - & Spița neamului <răzeșilor din > Petrești & românesc \\
\hline 242 & 1811 & aprilie & 14 & Spița neamului Căzăcesc & ” \\
\hline 243 & 1819 & iunie & 28 & Spița neamului Onofrei & ” \\
\hline 244 & - & - & - & Spița neamului „Spănie” & ” \\
\hline 245 & - & - & - & Spița neamului Cheptenița & 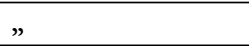 \\
\hline 246 & - & - & - & Spița neamului Savin & 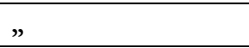 \\
\hline 247 & - & - & - & Spița neamului Nicoară & ” \\
\hline 248 & - & - & - & Spița neamului lui „Cozova” sluger & " \\
\hline 249 & 1773 & august & 10 & Ordinul lui <Alexandru> Rimschi Corsacov & rusesc \\
\hline 250 & 1813 & mai & 30 & Jalba lui Toader „Borgeianu”" ${ }^{4}$ către domn & românesc \\
\hline 251 & 1801 & mai & 19 & $\begin{array}{l}\text { Cartea lui Alexandru Moruzi voievod, dată lui Ivan } \\
\text { <şi lui > Grigoraș Perju, spre a i se face dreptatea pe } \\
\text { care o reclamă în jalbă }\end{array}$ & $"$ \\
\hline 252 & 1805 & februarie & 18 & $\begin{array}{l}\text { Zapis de vînzare a } 98 \text { stînjeni a lui Ion Perjul, < }<\text { din } \\
\text { moșia Trăisteni > } 55\end{array}$ & ” \\
\hline 253 & 1796 & martie & 10 & $\begin{array}{l}\text { Mărturia lui Ion Cuhureanul pentru vînzarea unei } \\
\text { părți din Floceni }\end{array}$ & ” \\
\hline 254 & - & august & 15 & $\begin{array}{l}\text { Zapisul lui Constantin Burcă de vînzare a unei părți } \\
\text { din moșia Măgura-Mare }\end{array}$ & ” \\
\hline 255 & 1799 & august & 22 & Jalba lui Ioniță Uscatul mazil către domnie & " \\
\hline 256 & 1799 & august & 30 & $\begin{array}{l}\text { Porunca domnului către ispravnici pentru cererea } \\
\text { lui Uscatu }\end{array}$ & $"$ \\
\hline
\end{tabular}

\footnotetext{
${ }^{51}$ Boga (1929e), p. 1-2, nr. 1.
}

${ }^{52}$ În text, greșit: „lui Donici”. Boga (1938a), p. 268-271, nr. LXXIII.

${ }^{53}$ Rezumatul este greșit: „Cartea mitropolitului Pavel în pricina de judecată între Prajescu și Hâncu”. Pavel este polcovnicul Pavel Debrici de la Mitropolie, copistul actului. Boga (1929d), p. 27-28, nr. XXIV.

${ }^{54}$ Poate „Bordeianu”.

${ }^{55}$ Doc. T. Mold., XII, p. 288, nr. 302.

${ }^{56}$ Doc. T. Mold., XI, p. 319-320, nr. 256. 


\begin{tabular}{|c|c|c|c|c|c|}
\hline 257 & 1799 & decembrie & 7 & $\operatorname{Idem}^{57}$ & " \\
\hline 258 & 1800 & aprilie & 16 & Jalba lui Ioniță Uscatul către domnie & 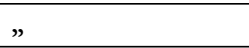 \\
\hline 259 & - & septembrie & 7 & Mărturia lui Constantin „Tumtu” din Dumbrăvița & " \\
\hline 260 & 1800 & aprilie & 18 & $\begin{array}{l}\text { Porunca lui }<\text { Constantin }>\text { Alexandru }<\text { Ipsilanti }{ }^{58} \\
\text { voievod către ispravnicii ținutului Iașis }{ }^{59}\end{array}$ & ” \\
\hline 261 & 1801 & aprilie & 5 & $\begin{array}{l}\text { Porunca lui < Constantin > Alexandru }<\text { Ipsilanti }{ }^{60} \\
\text { către ispravnicii ținutului Iași }\end{array}$ & " \\
\hline 262 & 1807 & august & 25 & Jalba lui Ioniță Uscatul către domnie & $"$ \\
\hline 263 & 1801 & aprilie & 15 & $\begin{array}{l}\text { Porunca ispravnicilor ținutului Iași către Ioniță } \\
\text { Mereacre }\end{array}$ & $"$ \\
\hline 264 & 1809 & iunie & 4 & $\begin{array}{l}\text { Jalba lui Ioniță Uscatu către Divanul Cnejiei } \\
\text { Moldovei }\end{array}$ & " \\
\hline 265 & $\frac{7258}{1749}$ & decembrie & 9 & $\begin{array}{l}\text { Suret după zapisul de așezarea răzeșilor din } \\
\text { Rădeni }^{62}\end{array}$ & " \\
\hline 266 & 1820 & septembrie & 5 & $\begin{array}{l}\text { Copia după hotărîrea Judecătoriei ținutului Iași în } \\
\text { pricina lui Zamfir „Cmerescu” }\end{array}$ & " \\
\hline 267 & 1806 & iunie & 2 & Pricina de judecată între Volcinschi și Donică ${ }^{63}$ & $\begin{array}{l}\text { românesc, cu trad. } \\
\text { rusească }\end{array}$ \\
\hline 268 & - & - & - & $\begin{array}{l}\text { Raportul boierilor în pricina de judecată a răzeșilor } \\
\text { din Cojușna }\end{array}$ & " \\
\hline 269 & $\frac{7273}{1765}$ & iulie & 22 & $\begin{array}{l}\text { Raportul boierilor în pricina de judecată a răzășilor } \\
\text { din Cojușna }^{65}\end{array}$ & " \\
\hline 270 & - & - & - & $\begin{array}{l}\text { Zapisul Ilenei, < fiica > lui Andronachi Ichim, prin } \\
\text { care vinde partea din moșia Hulboca }\end{array}$ & românesc \\
\hline 271 & 1799 & aprilie & 23 & $\begin{array}{l}\text { Zapisul lui Andronic prin care vinde parte din } \\
\text { Hulboca }{ }^{67}\end{array}$ & $"$ \\
\hline 272 & 1799 & mai & 25 & $\begin{array}{l}\text { Zapisul lui Alexandru }<\text { Borilă }>^{68} \text { prin care vinde } \\
\text { parte din Valea Adâncă }{ }^{69}\end{array}$ & $"$ \\
\hline $\begin{array}{c}274 \\
70\end{array}$ & 1800 & mai & 8 & $\begin{array}{l}\text { Zapisul lui Vartic prin care vinde parte din Valea } \\
\text { Adâncă }\end{array}$ & " \\
\hline 275 & 1800 & decembrie & 10 & $\begin{array}{l}\text { Zapisul lui Pavel Varzar prin care vinde parte din } \\
\text { Valea Adâncă }\end{array}$ & " \\
\hline 276 & 1801 & februarie & 20 & Zapisul lui Axente prin care vinde parte din Micăuți & " \\
\hline 277 & 1801 & februarie & 20 & Zapisul lui Balan prin care vinde parte din Cricova & " \\
\hline 278 & 1801 & februarie & 28 & Zapisul lui Sava prin care vinde parte din Miclești & ” \\
\hline 279 & 1801 & februarie & 28 & $\begin{array}{l}\text { Zapisul lui Toader Agapii prin care vinde parte din } \\
\text { Holboca de Jos }\end{array}$ & ” \\
\hline 280 & 1801 & februarie & 28 & $\begin{array}{l}\text { Zapisul lui Toader Agapii prin care vinde parte din } \\
\text { Holboca de Jos }\end{array}$ & $"$ \\
\hline 281 & 1801 & martie & 6 & $\begin{array}{l}\text { Zapisul lui Nistor logofăt prin care vinde parte din } \\
\text { moșia Holboca }\end{array}$ & $"$ \\
\hline
\end{tabular}

${ }^{57}$ Doc. T. Mold., XI, p. 325, nr. 261.

${ }^{58}$ În text: „Spr.”.

${ }^{59}$ Doc. T. Mold., XI, p. 329, nr. 267.

${ }^{60}$ Aceeași prescurtare: „Spr.”.

${ }^{61}$ Doc. T,.Mold., XII, p. 54-55, nr. 12.

${ }^{62} \mathrm{MEF}, \mathrm{VIII}$, p. 214-215, nr. 174.

${ }^{63}$ Vezi mai sus, nr. 93.

${ }^{64}$ Boga (1938a), p. 63-70, nr. XXVI (sfîrșitul actului lipsește, iar numele boierilor hotarnici nu-l putem ști). Se poate data în funcție de documentul următor.

${ }^{65}$ Boga (1938a), p. 70-72, nr. XXVII; Doc. Ț.Mold., IX, p. 166-168, nr. 143.

${ }^{66}$ Doc. T. Mold., XI, p. 321, nr. 258 (cu data: „1 octombrie 1799”).

${ }^{67}$ Doc. T. Mold., XI, p. 309, nr. 247.

${ }^{68}$ În text: „Boulă”.

${ }^{69}$ Doc. T,.Mold., XI, p. 311-312, nr. 250.

${ }^{70}$ Numărul 273 lipsește. 


\begin{tabular}{|c|c|c|c|c|c|}
\hline 282 & 1801 & mai & 30 & $\begin{array}{l}\text { Porunca lui Alexandru Ipsilanti voievod către } \\
\text { Isprăvnicia de Orheiu în pricina lui Gheorghe } \\
\text { vameșul }\end{array}$ & " \\
\hline 283 & 1801 & septembrie & 15 & $\begin{array}{l}\text { Porunca Sărdăriei Orheiului către capitanul Costin } \\
\text { în pricina lui Gheorghe vameșul }\end{array}$ & " \\
\hline 284 & 1802 & septembrie & 1 & $\begin{array}{l}\text { Zapisul Zoiței, fata lui Rezmeriță, prin care vinde } \\
\text { partea din Valea Adâncă }\end{array}$ & ” \\
\hline 285 & 1802 & noiembrie & 2 & $\begin{array}{l}\text { Zapisul Aniței, fata lui Ioniță, prin care vinde parte } \\
\text { din Valea Adâncă }\end{array}$ & ” \\
\hline 286 & 1803 & octombrie & 11 & $\begin{array}{l}\text { Raportul Sărdăriei de Orheiu către Logofeția cea } \\
\text { Mare în pricina lui Gheorghie Țigara < vameș> }\end{array}$ & ” \\
\hline 287 & 1803 & octombrie & 20 & Cartea Divanului în pricina vameșului Gheorghe & ” \\
\hline 288 & 1804 & aprilie & 10 & $\begin{array}{l}\text { Zapisul preotului Vasile prin care vinde parte din } \\
\text { moșia Holboca }\end{array}$ & $"$ \\
\hline 289 & 1804 & septembrie & 10 & $\begin{array}{l}\text { Porunca lui Constantin Moruzi voievod către } \\
\text { ispravnicul de Orheiu în pricina lui Gheorghe } \\
\text { vameșul }\end{array}$ & " \\
\hline 290 & 1810 & august & 26 & $\begin{array}{l}\text { Porunca Vorniciei de Aprozi către Constantin } \\
\text { telalbașa în pricina moșiei Petricani }\end{array}$ & ” \\
\hline 291 & 1812 & ianuarie & 18 & Idem, moşiile cumpărate la mezat de Țigara & ” \\
\hline 292 & 1801 & martie & 6 & $\begin{array}{l}\text { Zapisul lui Apostol Casap prin care vinde parte din } \\
\text { Valea Adâncă }\end{array}$ & " \\
\hline 293 & 1800 & decembrie & 10 & $\begin{array}{l}\text { Zapisul Anisiei „Canava” prin care vinde parte din } \\
\text { Valea Adâncă }\end{array}$ & ” \\
\hline 294 & 1836 & septembrie & 15 & Izvod de documenturile moșiei Holboca & ” \\
\hline 295 & $\frac{7106}{1598}$ & mai & 5 & $\begin{array}{l}\text { Zapisul lui Ion din Forosna prin care vinde o bucată } \\
\text { de pămînt }\end{array}$ & $\begin{array}{l}\text { slovenesc, cu trad. } \\
\text { rusească }\end{array}$ \\
\hline 296 & $\frac{7112}{1603}$ & octombrie & 8 & $\begin{array}{l}\text { Cartea lui Gheorghe pîrcălabul de Hotin prin care } \\
\text { întărește o vînzare }\end{array}$ & " \\
\hline 297 & $\frac{7212}{1704}$ & iunie & 15 & $\begin{array}{l}\text { Cartea lui Mihai Racovița voievod, dată lui Ștefan } \\
\text { Strășcă, pentru un loc la Șerbinița }\end{array}$ & copie, românească \\
\hline 298 & 1818 & mai & 30 & $\begin{array}{l}\text { Copia după hotărîrea Departamentului I al } \\
\text { Basarabiei in pricina de judecată a răzeșilor din satul } \\
\text { Picioroganii }\end{array}$ & românesc \\
\hline 299 & 1776 & octombrie & 14 & $\begin{array}{l}\text { Zapisul lui Corne prin care vinde o bucată de loc } \\
\text { din Hulboca }\end{array}$ & $\begin{array}{l}\text { românesc, cu trad. } \\
\text { rusească }\end{array}$ \\
\hline 300 & 1803 & iulie & 13 & $\begin{array}{l}\text { Porunca Sărdăriei de Orheiu către vornicul de } \\
\text { poartă Jărdan spre a cerceta moșia Sferja }\end{array}$ & $"$ \\
\hline 301 & 1803 & iulie & 14 & Idem, către protopopul orașului Chişinău & ” \\
\hline 302 & 1803 & iulie & 14 & Zapisul răzășilor prin care vînd moșia lor de la Sferja & 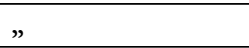 \\
\hline 303 & 1803 & septembrie & 20 & Împărțeala făcută între răzeșii moșiei Sferja & " \\
\hline 304 & 1803 & iulie & 24 & $\begin{array}{l}\text { Zapisul răzășilor din Sferja prin care vînd o parte } \\
\text { din moșie }\end{array}$ & " \\
\hline 305 & 1805 & mai & 3 & Zapisul lui Ioniță prin care vinde o parte din Sferja & ” \\
\hline 306 & 1817 & octombrie & 22 & $\begin{array}{l}\text { Zapisul lui Iordache Bargan prin care vinde o } \\
\text { bucată de loc din Sferja }\end{array}$ & " \\
\hline $\begin{array}{c}306 \\
74\end{array}$ & $\frac{7170}{1662}$ & martie & 10 & $\begin{array}{l}\text { Zapisul lui „Dorda” și surorii sale, „Furnica”, prin } \\
\text { care vînd o bucată de loc din Tuzora }\end{array}$ & " \\
\hline 307 & 1821 & iulie & 16 & $\begin{array}{l}\text { Zapisul babei Maria prin care vinde o bucată de loc } \\
\text { <împreună> cu Andrușca }\end{array}$ & $"$ \\
\hline 308 & 1823 & iunie & 2 & $\begin{array}{l}\text { Zapisul lui Gheorghe prin care vinde o bucată de } \\
\text { loc }\end{array}$ & $"$ \\
\hline
\end{tabular}

\footnotetext{
${ }^{71}$ Doc. T,. Mold., XII, p. 208-209, nr. 206.

${ }^{72}$ Boga (1930a), p. 348-349, nr. I; MEF, VI, p. 218-219, nr. 84.

${ }^{73}$ Doc. T,.Mold., X, p. 54, nr. 35.

${ }^{74}$ Număr dublat.
} 


\begin{tabular}{|c|c|c|c|c|c|}
\hline 309 & $\frac{7208}{1700}$ & iulie & 9 & Jalba lui Toader vornic către marele logofăt & $"$ \\
\hline 310 & 1810 & noiembrie & 10 & $\begin{array}{l}\text { Zapisul <ierei }>^{75} \text { Onofrei prin care vinde o bucată } \\
\text { de loc la Sferja }\end{array}$ & " \\
\hline 311 & 1819 & decembrie & 1 & $\begin{array}{l}\text { Zapisul lui Petrache Popa prin care vinde o bucată } \\
\text { de loc la Micăuți }\end{array}$ & ” \\
\hline 312 & 1824 & martie & - & $\begin{array}{l}\text { Copie după hotărîrea Judecătoriei ținutului Orheiu } \\
\text { în pricina lui Țigarescu }\end{array}$ & ” \\
\hline 313 & $\frac{7268}{1760}$ & iulie & 21 & $\begin{array}{l}\text { Zapisul lui Vasile Popa prin care vinde o bucată de } \\
\text { loc din Sipoteni }\end{array}$ & $”$ \\
\hline 314 & - & - & - & $\begin{array}{l}\text { Zapisul lui Simion prin care vinde o bucată de loc la } \\
\text { Sipoteni }\end{array}$ & românesc \\
\hline 315 & $<1759>$ & august & 11 & $\begin{array}{l}\text { Cartea lui Ioan < Teodor > Calimah voievod prin } \\
\text { care întărește lui „Dumenescu” un } \operatorname{loc}^{76}\end{array}$ & $\begin{array}{l}\text { copie românească, cu } \\
\text { trad. rusească }\end{array}$ \\
\hline 316 & 1790 & septembrie & 14 & $\begin{array}{l}\text { Zapisul lui Tanase prin care vinde o bucată de loc la } \\
\text { Cricova }\end{array}$ & $\begin{array}{l}\text { românesc, cu trad. } \\
\text { rusească }\end{array}$ \\
\hline 317 & 1791 & iulie & 22 & $\begin{array}{l}\text { Zapisul lui Tanase prin care vinde o bucată de loc la } \\
\text { Cricova }\end{array}$ & ” \\
\hline 318 & 1810 & octombrie & 10 & $\begin{array}{l}\text { Zapisul lui Moise „Fosul” prin care vinde o bucată } \\
\text { de loc la Sămășcani }\end{array}$ & ” \\
\hline 319 & 1814 & februarie & 7 & Spița de neam a Sfârjeștilor & ” \\
\hline 320 & 1813 & iunie & - & $\begin{array}{l}\text { Jalba lui Iordache Costin pentru o bucată de loc din } \\
\text { Călărași }\end{array}$ & românesc \\
\hline 321 & 1813 & septembrie & 13 & $\begin{array}{l}\text { Zapisul răzeșilor din moșia Tuzora prin care vînd } \\
\text { părțile lor din moșie }\end{array}$ & $\begin{array}{l}\text { românesc, cu trad. } \\
\text { rusească }\end{array}$ \\
\hline 322 & - & - & - & $\begin{array}{l}\text { Cererea răzeșilor din moșia Tuzora pentru părțile } \\
\text { lor de moșie. }\end{array}$ & $"$ \\
\hline 323 & 1832 & martie & 14 & Chitanța lui Ioan Pruncu pentru suma de 1.695 lei & românesc \\
\hline 324 & 1859 & martie & 3 & Scrisoarea lui Bulat către Petre Filipovici & rusesc, cu o copie \\
\hline 325 & - & - & - & Scrisoarea lui Turcan către Petre Feodorovici & rusesc \\
\hline 326 & 1805 & iunie & 29 & Hotarnica moșiei Glingenii, cu întărirea Divanului & românesc, copie \\
\hline 327 & 1795 & iunie & 17 & $\begin{array}{l}\text { Hotarnica moșiei Foleștii, <din ținutul Iași >, cu } \\
\text { întăritura Divanului }\end{array}$ & " \\
\hline 328 & 1795 & iunie & 24 & $\begin{array}{l}\text { Hotarnica moșiei Drăgușenii, <din ținutul Iași >, cu } \\
\text { intăritura Divanului }^{78}\end{array}$ & ” \\
\hline 329 & 1777 & februarie & 4 & $\begin{array}{l}\text { Zapisul lui Chiriac Mârzac pentru vînzarea unui loc } \\
\text { din Ciuciuleni }\end{array}$ & românesc \\
\hline 330 & 1774 & mai & 14 & $\begin{array}{l}\text { Zapisul lui Anastasie pentru vînzarea unui loc la } \\
\text { Soltănești }\end{array}$ & ” \\
\hline 331 & 1774 & aprilie & 11 & $\begin{array}{l}\text { Zapisul răzeșilor prin care vînd o bucată de loc din } \\
\text { Soltănești }^{79}\end{array}$ & ” \\
\hline 332 & 1787 & iulie & 8 & $\begin{array}{l}\text { Cartea lui Leon < Gheuca > mitropolitul Moldovei } \\
\text { in pricina lui Iftimie din Vărzărești }\end{array}$ & ” \\
\hline 333 & 1786 & decembrie & 2 & Carte de judecată a lui Ion Negară & ” \\
\hline 334 & 1800 & iunie & 10 & Jalba lui Mihai Bărgan către domnie & ” \\
\hline 335 & 1817 & noiembrie & 10 & Porunca Isprăvniciei Eșilor către ocolașul Codrului & ” \\
\hline 336 & 1806 & martie & 25 & Harta moșiei Măgurele & ” \\
\hline 337 & 1791 & noiembrie & 18 & $\begin{array}{l}\text { Zapisul lui Gheorghe Hărjău prin care vinde cîteva } \\
\text { părți din Budești }\end{array}$ & " \\
\hline
\end{tabular}

\footnotetext{
${ }^{75}$ În text: „iunei”.

${ }^{76}$ În text, data greșită: „1766”.

${ }^{77}$ Boga (1938a), p. 163-170, nr. XLIX; Doc. T,.Mold., XI, p. 211-217, nr. 159.

${ }^{78}$ Boga (1938a), p. 170-173, nr. L.

${ }^{79}$ Doc. T. Mold., IX, p. 240-241, nr. 210.
} 


\begin{tabular}{|c|c|c|c|c|c|}
\hline 338 & $\begin{array}{l}7292 \\
<1784>\end{array}$ & iulie & 2 & $\begin{array}{l}\text { Zapisul lui Sandul Orbul prin care vinde o parte } \\
\text { din moșia Văsieni, < <in ținutul Lăpușna > } 80\end{array}$ & $"$ \\
\hline 339 & 1816 & octombrie & 12 & $\begin{array}{l}\text { Zapisul Plămădeștilor prin care vînd o parte din } \\
\text { Valea Vișinii, <de la Văsieni }>^{81}\end{array}$ & $"$ \\
\hline 340 & 1816 & octombrie & 2 & $\begin{array}{l}\text { Zapisul lui Proca Plămădeală prin care se învoește } \\
\text { cu ai lui la o împărțeală }\end{array}$ & " \\
\hline 341 & 1814 & iunie & 24 & $\begin{array}{l}\text { Chitanța, dată lui Braşoveanu, pentru caii dăruiți } \\
\text { armatei }\end{array}$ & ” \\
\hline 342 & 1814 & iunie & 12 & Chitanța de 50 galbeni a lui Iordache Donici & 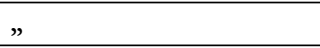 \\
\hline 343 & $\frac{6987}{1479}$ & august & 11 & $\begin{array}{l}\text { Hrisovul lui Ștefan voievod prin care întărește } \\
\text { vînzarea satelor Mănești și Sărbicești }{ }^{82}\end{array}$ & $\begin{array}{l}\text { pergament, cu pecete } \\
\text { atîrnată }\end{array}$ \\
\hline 344 & $\frac{7080}{1572}$ & - & - & Document slovenesc, deteriorat, cu pecete atîrnată & nu se poate citi nimic \\
\hline 345 & $\frac{7113}{1605}$ & martie & 27 & $\begin{array}{l}\text { Cartea lui Eremia Movilă voievod, dată lui <Ilie } \\
\text { Băcioc }>^{83} \text {, pentru satul Cupcici pe Ciuhur }{ }^{84}\end{array}$ & $\begin{array}{l}\text { pergament, rupt la } \\
\text { pecete }\end{array}$ \\
\hline 346 & - & - & - & Spița neamului Sferjesc & românesc \\
\hline 347 & - & - & - & Spița neamului Ianculesc & ” \\
\hline 348 & 1812 & august & 26 & Spița neamului Sferjă & " \\
\hline 349 & - & - & - & Spița moşiei Puhoiul & 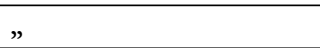 \\
\hline 350 & 1797 & august & 16 & Spița neamului < răzeșilor din moșia > Olișcani & 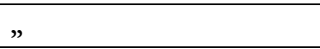 \\
\hline 351 & - & - & - & Spița pentru moșia Tuzora & " \\
\hline 352 & - & - & - & Idem & 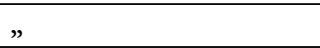 \\
\hline 353 & 1812 & - & - & Spița neamului lui Cozma sluger & 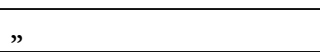 \\
\hline 354 & 1830 & mai & 29 & Chitanța lui Harște de primirea unor documente & " \\
\hline 355 & 1794 & noiembrie & 10 & Mărturia hotarnică pentru moșia Bravicea & ” \\
\hline 356 & 1795 & " & 3 & Cartea de judecată pentru moșia Bravicea & " \\
\hline 357 & 1797 & mai & 30 & Cartea de judecată pentru moșia Bravicea & ” \\
\hline 358 & 1794 & octombrie & 29 & $\begin{array}{l}\text { Carte privitoare la cercetarea pricinii lui Grigoras, } \\
\text { Varzar }\end{array}$ & ” \\
\hline 359 & 1814 & iulie & 2 & Referatul veliților boieri in pricina lui Ilie Ilschi & ” \\
\hline 360 & 1810 & august & 9 & $\begin{array}{l}\text { Divanul Cnejiei Moldovei către Vornicia de Aprozi } \\
\text { în pricina moșiei Babini }\end{array}$ & $"$ \\
\hline 361 & 1810 & august & 26 & $\begin{array}{l}\text { Adresa Senatorului. Milașevici către Divan în } \\
\text { pricina moșiei Babenii }\end{array}$ & $\begin{array}{l}\text { românesc, cu trad. } \\
\text { rusească }\end{array}$ \\
\hline 362 & 1810 & august & 2 & Idem, în aceeaşi pricină & 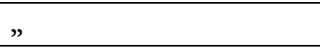 \\
\hline 363 & 1810 & iunie & 22 & Idem, cu aceeași pricină & " \\
\hline 364 & $\frac{7209}{1701}$ & martie & 20 & Suret de împărțeala Brăeștilor ${ }^{85}$ & $\begin{array}{l}\text { românesc, cu trad. } \\
\text { rusească și <copie> } \\
\text { românească }\end{array}$ \\
\hline 365 & $\frac{7109}{1601}$ & mai & 20 & $\begin{array}{l}\text { Cartea lui Eremia Movilă voievod pentru satul } \\
\text { Babini, <ținutul Hotin }>86\end{array}$ & $\begin{array}{l}\text { slovenesc, rupt, cu trad. } \\
\text { românească }\end{array}$ \\
\hline 366 & - & iunie & 3 & Zapis de marturie privitor la satul Babini ${ }^{87}$ & $\begin{array}{l}\text { slovenesc, cu trad. } \\
\text { românească }\end{array}$ \\
\hline 367 & 1818 & aprilie & 30 & $\begin{array}{l}\text { Adeverința lui Papadopulo că a cumpărat venitul } \\
\text { moșiei „Panova” }\end{array}$ & grecesc \\
\hline 368 & 1822 & aprilie & 23 & Idem & " \\
\hline
\end{tabular}

${ }^{80}$ Doc. T. Mold., X, p. 173, nr. 139 (cu data de zi: „10”); Candu (2014a), p. 54.

${ }^{81}$ Pentru Proca Plămădeală și familia lui, vezi Candu (2014b), p. 200.

${ }^{82}$ Boga (1929b), p. 10-12, nr. X.

${ }^{83}$ În text, greșit: „Cornea”.

${ }^{84} \mathrm{Boga}$ (1929f), p. 78-81, nr. V; MEF, III, p. 34-37, nr. 10 (cu data de zi: „26”).

${ }^{85}$ Boga (1929a), p. 7-9, nr. III; MEF, VI, p. 209-212, nr. 80.

${ }^{86}$ Boga (1929f), p. 72-73, nr. I.

${ }^{87}$ Având în vedere că actul este slav, cred că se poate data la începutul sec. XVII (vezi și doc. nr. 365). 


\begin{tabular}{|c|c|c|c|c|c|}
\hline 369 & 1822 & iulie & 15 & $\begin{array}{l}\text { Povestca }^{88} \text { ce s-au trimis de la Isprăvnicie către } \\
\text { Papadopol }\end{array}$ & românesc \\
\hline 370 & 1822 & iulie & 7 & $\begin{array}{l}\text { Răspunsul <luii }{ }^{89} \text { Papadopol către Isprăvnicia } \\
\text { ținutului Iași }\end{array}$ & copie, românesc \\
\hline 371 & 1822 & iunie & 16 & $\begin{array}{l}\text { Scrisoarea lui Papadopol către egumenul mănăstirii } \\
\text { Cetățuia }\end{array}$ & $\begin{array}{l}\text { grecesc, cu trad. } \\
\text { românească }\end{array}$ \\
\hline 372 & 1788 & septembrie & 12 & Adeverința dată protopopului Iacov pentru 200 lei & românesc \\
\hline 373 & - & - & - & Planul satului „Coropcanții”"90 & ” \\
\hline 374 & 1821 & noiembrie & 5 & $\begin{array}{l}\text { Mărturia sătenilor din Cepeleuți de felul cum este } \\
\text { așezată moșia }\end{array}$ & " \\
\hline 375 & 1775 & iunie & 16 & $\begin{array}{l}\text { Cartea lui Alexandru Grigore Ghica voievod } \\
\text { pentru moșia Brădeni }\end{array}$ & ” \\
\hline 376 & $\frac{7015}{1508}$ & februarie & 26 & $\begin{array}{l}\text { Cartea lui Bogdan voievod, dată lui Cozma }<s ̦ i \\
\text { altora }>\text {, pentru moșia Trestioara } \\
\end{array}$ & traduceri din 1818 \\
\hline 377 & 1818 & septembrie & 21 & $\begin{array}{l}\text { Adeverința lui Costache de primire a unor } \\
\text { documente }\end{array}$ & ” \\
\hline 378 & 1818 & iulie & 22 & $\begin{array}{l}\text { Adeverința razeșilor din neamul „Tăulesc” pentru } \\
\text { moșua Puhoiul }\end{array}$ & ” \\
\hline 379 & 1817 & februarie & 27 & $\begin{array}{l}\text { Zapisul lui Grigorie Curnic pentru o bucată de loc } \\
\text { din satul Văsieni }\end{array}$ & ” \\
\hline 380 & 1811 & ianuarie & 31 & Porunca Sărdăriei de Orheiu pentru moșia „Tărchi” & ” \\
\hline 381 & 1810 & noiembrie & 7 & $\begin{array}{l}\text { Porunca Sărdăriei de Orheiu către < Iacovachi }>{ }^{93} \\
\text { pentru moșia Puhoiu }\end{array}$ & ” \\
\hline 382 & $\frac{7240}{1732}$ & mai & 4 & Diata lui Grigoraș, < fiul lui popa Lupul> ${ }^{94}$ & ” \\
\hline 383 & 1814 & iunie & 6 & $\begin{array}{l}\text { Porunca către Iordachi Donici ca să facă socoteala } \\
\text { veniturilor }\end{array}$ & $\begin{array}{l}\text { românesc, cu trad. } \\
\text { rusească }\end{array}$ \\
\hline 384 & 1814 & iunie & 12 & $\begin{array}{l}\text { Declarația lui Vasilie Cațichi pentru donația unor } \\
\text { case }\end{array}$ & ” \\
\hline 385 & 1814 & iunie & 10 & $\begin{array}{l}\text { Porunca către Iordache Donici, Ana Rusu și P. } \\
\text { Catargiu pentru socoteala veniturilor }\end{array}$ & românesc \\
\hline 386 & $\frac{7078}{1570}$ & martie & 3 & $\begin{array}{l}\text { Cartea lui Bogdan voievod dată lui Andreico } \\
\text { pentru moșia Arpășeștii }\end{array}$ & $\begin{array}{l}\text { slovenesc, pe } \\
\text { pergament, pecetea } \\
\text { căzută }\end{array}$ \\
\hline 387 & - & - & - & $\begin{array}{l}\text { Însemnare de moșiile ce sînt a Naculeștilor şi a } \\
\text { Samsoneștilor }\end{array}$ & românesc \\
\hline 388 & 1819 & mai & 26 & Spița neamului Codrăneștilor și Doltești & " \\
\hline 389 & 1821 & ianuarie & 14 & Spița neamului $<$ din $>{ }^{96}$ Miron Costin & ” \\
\hline 390 & $\frac{7249}{\frac{5508}{1741}}$ & iulie & 1 & Referatul către domn în pricina moșiei Cărbuna & ” \\
\hline 391 & - & - & - & $\begin{array}{l}\text { Zapisul către Efrem Hajdeu prin care i se confirmă } \\
\text { mai multe cumpărături }\end{array}$ & ” \\
\hline 392 & - & - & - & $\begin{array}{l}\text { Cartea părcălabului de Hotin prin care confirmă } \\
\text { vînzarea unui loc }\end{array}$ & $\begin{array}{l}\text { slovenesc, cu trad. } \\
\text { românească }\end{array}$ \\
\hline
\end{tabular}

\footnotetext{
${ }^{88}$ Rusism: „citație”.

${ }^{89}$ În text: „prot.”.

${ }^{90}$ Probabil, „Coropceni” (ținutul Orhei).

${ }^{91}$ Doc. T. Mold., X, p. 27, nr. 8.

${ }^{92}$ Boga (1929c), p. 3-4, nr. I.

${ }^{93}$ Propun această corectură; în text: „Iascov vac”.

${ }^{94}$ În text, greșit: „Popadopul”; Boga (1929a), p. 10-11, nr. VI (cu data de lună: „martie”); MEF, VIII, p. 111-112, nr. 80 (cu data de lună: „mai”).

${ }^{95}$ Boga (1929c), p. 18-21, nr. XVI.

${ }^{96}$ În text: „de”.
} 


\begin{tabular}{|c|c|c|c|c|c|}
\hline 393 & - & martie & 18 & $\begin{array}{l}\text { Zapisul lui Grițco Răspop prin care vinde o bucată } \\
\text { de loc din }\left\langle\text { Nisfoaia }{ }^{97} \text {, ținutul Lăpușna }>\right.\end{array}$ & $\begin{array}{l}\text { slovenesc, cu trad. } \\
\text { românească }\end{array}$ \\
\hline 394 & $\frac{7128}{1620}$ & iunie & 20 & $\begin{array}{l}\text { Zapisul Marinei prin care vinde o bucată de loc din } \\
\text { Citnicăuți }\end{array}$ & $"$ \\
\hline 395 & $\frac{7127}{1619}$ & iunie & 6 & $\begin{array}{l}\text { Cartea lui Gasspar voievod pentru o parte din satul } \\
\left.<\text { Scitnicăuți }{ }^{8} \text {, ținutul Hotin }\right\rangle^{99}\end{array}$ & ” \\
\hline 396 & - & - & - & $\begin{array}{l}\text { Zapisul lui Nicoară Moțoc prin care vinde o parte } \\
\text { din moșia Citnicăuți }\end{array}$ & românesc \\
\hline 397 & - & - & - & Zapisul lui Ursul prin care vinde un loc în Curileni & ” \\
\hline 398 & $\frac{7178}{1670}$ & iunie & 5 & $\begin{array}{l}\text { Zapisul fiicei lui Efim Hajdău prin care vinde o } \\
\text { parte din Hrușăvaț }\end{array}$ & $"$ \\
\hline 399 & 1783 & mai & - & $\begin{array}{l}\text { Cartea lui Alexandru Constantin <Mavrocordat> } \\
\text { voievod, dată lui Lascarachi Roset vel vornic, } \\
\text { pentru moșia Hăsnășenii, <ținutul Soroca > } 100\end{array}$ & $"$ \\
\hline 400 & - & - & - & $\begin{array}{l}\text { Uricul de Irimia voievod, dat lui }\left\langle\text { Romșa }>^{101} \text { vătav, }\right. \\
\text { pentru moșia Negrinți, }<\text { ținutul Hotin, și pentru } \\
\text { alte sate }>\end{array}$ & $\begin{array}{l}\text { copie, traducere } \\
\text { românească }\end{array}$ \\
\hline 401 & 1766 & august & 27 & $\begin{array}{l}\text { Cartea lui Alexandru Ghica voievod dată lui Lupu } \\
<\text { Totoescul }>{ }^{103} \text { pentru moșia Iordănești }{ }^{104}\end{array}$ & românesc \\
\hline 402 & $\frac{7254}{1746}$ & ianuarie & 26 & $\begin{array}{l}\text { Foaia de zestre ce o dă Ruxandra Hajdău fiicei sale, } \\
\text { Catrina, }<c u>\text { satul Iordănești }\end{array}$ & ” \\
\hline 403 & 1765 & martie & 29 & $\begin{array}{l}\text { Cartea lui Grigorie Alexandru Ghica voievod către } \\
\text { serdarii „Sucevei” }{ }^{105} \text { in pricina satului Iordănești }\end{array}$ & ” \\
\hline 404 & $\frac{7221}{1713}$ & mai & 13 & $\begin{array}{l}\text { Zapisul Ruxandei Hajdău prin care vinde jumătate } \\
\text { de sat Iordănești }\end{array}$ & $"$ \\
\hline $\begin{array}{l}404 \\
106\end{array}$ & 1783 & aprilie & 16 & $\begin{array}{l}\text { Polița de lei 37.320, luați de la Sandul Sturza de } \\
\text { Iamandi }\end{array}$ & $\begin{array}{l}\text { românesc, cu trad. } \\
\text { rusească }\end{array}$ \\
\hline 405 & 1782 & martie & 23 & $\begin{array}{l}\text { Jalba lui Andrei „Borca ot” Iordănești asupra } \\
\text { Ilinchii Stărcioaei }\end{array}$ & românesc \\
\hline 406 & 1786 & iulie & 12 & Notă de diverse datorii & ” \\
\hline 407 & 1782 & februarie & 12 & $\begin{array}{l}\text { Scrisoarea prin care mărturisește Andrei de } \\
\text { documentele primite }\end{array}$ & ” \\
\hline 408 & 1793 & aprilie & 21 & $\begin{array}{l}\text { Zapisul lui Macarie prin care mărturisește că a } \\
\text { primit mai multe documente }\end{array}$ & $”$ \\
\hline 409 & 1816 & mai & 30 & $\begin{array}{l}\text { Certificat prin care se stabilește că Toader face parte } \\
\text { din familia Hăjdău }\end{array}$ & rusesc \\
\hline 410 & 1843 & septembrie & 26 & Planul moșiei „Cogurlui”" ${ }^{207}$ & 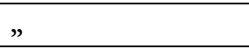 \\
\hline 411 & 1822 & iunie & 3 & Planul moșiei Pașcăuți, < din ținutul Hotin> & ” \\
\hline 412 & 1836 & octombrie & 31 & Planul moșiei „Gurnești”108 & ” \\
\hline 413 & 1827 & - & - & Planul moșiei Mereșeni ${ }^{109}$ & $"$ \\
\hline 414 & - & - & - & Izvod de zestre dat de Grierosu & românesc \\
\hline
\end{tabular}

\footnotetext{
${ }^{97}$ În text: „Nesforia”.

${ }^{98}$ În text, greșit: „Cituic”.

${ }^{99}$ Boga (1929f), p. 93-94, nr. XIV; MEF, I, p. 351-353, nr. 154.

${ }^{100}$ Boga (1931a), p. 63-65, nr. LI; Doc. T,.Mold., X, p. 146-148, nr. 108.

${ }^{101}$ În text: „Comșa”.

${ }^{102}$ Boga (1929f), p. 74-75, nr. II; Boga (1929d), p. 5-7, nr. III (fără dată).

${ }^{103}$ În text, doar: „fost”.

${ }^{104}$ Doc. T..Mold., IX, p. 189-190, nr. 163 (cu data de zi: „27”).

${ }^{105}$ Așa în text.

${ }^{106}$ Număr dublat.

${ }^{107}$ Probabil, „Cruhlic” (ținutul Hotin).

${ }^{108}$ Probabil, „Grimești” (ținutul Hotin).

109 „Mereșăuți” (ținutul Hotin).
} 


\begin{tabular}{|c|c|c|c|c|c|}
\hline 415 & 1834 & septembrie & 7 & $\begin{array}{l}\text { Scrisoarea de la } \mathrm{R}<\text { iter }>\text { von Buhental } \\
<\text { Dobrovolschi, aflat la Grămești > către Iordache }\end{array}$ & $”$ \\
\hline 416 & - & - & - & $\begin{array}{l}\text { Scrisoarea către } \mathrm{R}<\text { iter > von Buhental } \\
<\text { Dobrovolschi> prin care se arată niște datorii }\end{array}$ & ” \\
\hline 417 & 1835 & ianuarie & 15 & $\begin{array}{l}\text { Scrisoarea lui Ioan Hajdău, <aflat la Vorniceni>, } \\
\text { către Iordache }{ }^{111}\end{array}$ & " \\
\hline 418 & 1815 & martie & 29 & Socoteala cu dumnealui Petrea von Vlahovici & ” \\
\hline 419 & 1830 & septembrie & 9 & Vechilimeaua dată de Polizu lui Beiderman & $\begin{array}{l}\text { românesc, cu un ad }<\text { aos } \\
\text { nem }>\text { țesc }\end{array}$ \\
\hline 420 & 1820 & iulie & 27 & Vechilimeaua dată de Vlahovici lui Polizu & românesc \\
\hline 421 & 1815 & februarie & 5 & $\begin{array}{l}\text { Scrisoarea lui P. Vlahovici către }<\text { căminarul }^{112} \\
\text { Mihalache }\end{array}$ & $\begin{array}{l}\text { românesc, cu trad. } \\
\text { grecească }\end{array}$ \\
\hline 422 & 1858 & octombrie & 12 & Ravașul <Valeriei $>{ }^{113}$ Hajdău către S. Hajdău & rusesc \\
\hline 423 & 1821 & august & 22 & $\begin{array}{l}\text { Hotărîrea Judecătoriei ținutului Orheiu în pricina } \\
\text { lui Vasilie Boțan }\end{array}$ & românesc \\
\hline 424 & - & - & - & Răzeșii din Curileni se plîng la domnie & ” \\
\hline 425 & 1800 & mai & 14 & $\begin{array}{l}\text { Cartea lui Constantin Ipsilanti voievod către } \\
\text { Serdăria de Orheiu in pricina răzeșilor din } \\
\text { Curileni }^{114}\end{array}$ & " \\
\hline 426 & 1802 & iulie & 5 & $\begin{array}{l}\text { Raportul lui Ion <Canta paharnic }>^{115} \text { în pricina } \\
\text { răzeșilor din Curileni, <ținutul Orhei, cu moșia } \\
\text { Crucerești }>^{116}\end{array}$ & ” \\
\hline 427 & 1802 & iulie & 6 & $\begin{array}{l}\text { Zapis de învoială între Vârgolici și răzeșii din } \\
\text { Curileni }\end{array}$ & ” \\
\hline 428 & 1814 & iunie & 20 & $\begin{array}{l}\text { Act de învoială a lui Chiriac cu răzeșii moșiei } \\
\text { Cojușna }\end{array}$ & $\begin{array}{l}\text { românesc, cu trad. } \\
\text { rusească }\end{array}$ \\
\hline 429 & 1814 & iunie & 23 & Idem & ” \\
\hline 430 & 1812 & aprilie & 23 & Zapis de la Chiriac pentru venitul din Cojușna & ” \\
\hline 431 & 1805 & februarie & 11 & $\begin{array}{l}\text { Raport de la Isprăvnicia Sucevei către <Logofeția } \\
\text { Țării de Sus }>117\end{array}$ & românesc \\
\hline 432 & 1820 & mai & 4 & Jalba lui Pascal către domn & ” \\
\hline 433 & 1781 & iulie & 23 & $\begin{array}{l}\text { Cartea lui Constantin Moruzi voievod prin care } \\
\text { întărește pricina de judecată a moșiei Vlădeni, } \\
<\text { ținutul Cernăuți }>118\end{array}$ & ” \\
\hline 434 & 1781 & noiembrie & 28 & Jalba către domn in pricina lui Ciomărtan & românesc \\
\hline 435 & 1779 & iunie & 13 & Jalba către domn în pricina moșiei Vlădeni & ” \\
\hline 436 & 1804 & august & 4 & Act de învoială între neamurile „Dobocești” & " \\
\hline 437 & 1774 & ianuarie & 11 & $\begin{array}{l}\text { Răspunsul lui Cantacuzino către Divan în pricina } \\
\text { moșiei Mironeștilor }\end{array}$ & " \\
\hline 438 & 1859 & ianuarie & 28 & $\begin{array}{l}\text { Scrisoarea arhimandritului Damian, <egumenul } \\
\text { mănăstirii Răducanu din Tîrgul Ocna>, către } \\
\text { locuitorii din Vladicina }^{119}\end{array}$ & ” \\
\hline 439 & 1859 & iunie & 29 & Adeverința de 100 ruble a egumenului Damaschin & ” \\
\hline 440 & 1851 & august & 12 & $\begin{array}{l}\text { Scrisoarea egumenului Damaschin către locuitorii } \\
\text { din Vlădicina }\end{array}$ & ” \\
\hline
\end{tabular}

\footnotetext{
${ }^{110}$ Boga (1928b), p. 129, nr. CLXXVIII.

${ }^{111}$ Rezumatul are data de an greșită: „1885”. Boga (1928b), p. 130, nr. CLXXIX.

${ }^{112}$ In text: „carm.”.

${ }^{113}$ În text: „Voleru”.

${ }^{114}$ Doc. T,. Mold., XI, p. 332-333, nr. 270.

${ }^{115}$ În text, greșit: „Carp Pali”.

${ }^{116}$ Boga (1938a), p. 218-221, nr. LXI; Doc. T. Mold., XII, p. 113-115, nr. 90.

117 În text: „Logofățenii de Sus”.

${ }^{118}$ Boga (1931a), p. 62, nr. L (cu data de zi: „25”); Doc. T. Mold., X, p. 127-128, nr. 88.

${ }^{119}$ Rezumatul are data de an: 1858. Boga (1928b), p. 147-148, nr. CCIII.
} 


\begin{tabular}{|c|c|c|c|c|c|}
\hline 441 & 1850 & decembrie & 15 & Diata lui <Neculai, fiul lui Ioan > Doni paharnic ${ }^{120}$ & " \\
\hline 442 & 1840 & mai & 3 & Notă de cheltuielile făcute de S. Mano cu o judecată & " \\
\hline 443 & 1812 & septembrie & 29 & $\begin{array}{l}\text { Porunca Divanului Moldovei în pricina } \\
\text { căminarului Mihalache }\end{array}$ & " \\
\hline 444 & 1806 & noiembrie & 21 & Zapisul lui Hagi pentru vînzarea unei case & 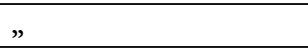 \\
\hline 445 & 1813 & iulie & 19 & Zapisul lui „Beliș” de vînzarea unui loc & ” \\
\hline 446 & $\frac{7262}{1754}$ & iulie & - & $\begin{array}{l}\text { Cartea lui Ion Matei Ghica voievod prin care } \\
\text { intărește lui }\langle\text { Cheșco }\rangle^{121} \text { o cumpărătură }\end{array}$ & copie \\
\hline 447 & - & martie & 20 & Răvaș de la Părcălabie către vornicii de la Costești & românesc \\
\hline 448 & 1820 & octombrie & 1 & $\begin{array}{l}\text { Izvorul documentelor prezentate la Judecătorie în } \\
\text { pricina Samsoneștilor }\end{array}$ & " \\
\hline 449 & 1807 & ianuarie & 28 & Porunca cazacului Laptev de la horungi ${ }^{122}$ Saracov & românesc și rusesc \\
\hline 450 & 1816 & octombrie & 9 & Învoiala între Ion Țăgăniuc și Maria ${ }^{123}$ Onciul & românesc \\
\hline 451 & 1816 & august & 4 & $\begin{array}{l}\text { Învoiala între Țiganiuc și Miron Onciul pentru } \\
\text { moșia Cruglic }\end{array}$ & " \\
\hline 452 & 1812 & decembrie & 18 & Zapis de vînzare al lui Moșanu & " \\
\hline 453 & 1811 & iulie & 15 & Învoiala între Anița și Ion Moșanu ${ }^{124}$ & ” \\
\hline 454 & 1812 & mai & 17 & Învoiala între Moșanu și Tudorache Ciurea & ” \\
\hline 455 & 1822 & aprilie & 23 & Socoteala venitului moșiei lui Moșanu & " \\
\hline 456 & 1814 & iulie & 7 & Chitanțe ale lui I. Moșanu (5) & " \\
\hline 457 & 1806 & noiembrie & 21 & $\begin{array}{l}\text { Zapisul lui Ismail bairactar de vînzare a două pietre } \\
\text { de moară și altele }\end{array}$ & românesc și polonez ${ }^{125}$ \\
\hline 458 & $\frac{7191}{1683}$ & martie & 10 & $\begin{array}{l}\text { Zapisul Vasilcăi de împărțirea averii sale între } \\
\text { copii }\end{array}$ & românesc \\
\hline 459 & 1809 & decembrie & 12 & $\begin{array}{l}\text { Scrisoarea dată de Gavril mitropolit și alții în } \\
\text { pricina satelor din Hotin }\end{array}$ & românesc, copie \\
\hline 460 & $\frac{7164}{1656}$ & iunie & 30 & $\begin{array}{l}\text { Cartea lui Gheorghe Ștefan către pîrcălabul de } \\
\text { Hotin }{ }^{127}\end{array}$ & copie românesască \\
\hline 461 & 1773 & martie & 11 & $\begin{array}{l}\text { Dovada de moșiile ce are în Hotin Vasile } \\
\text { Carbanovici }\end{array}$ & copie $<$ românească $>$ \\
\hline 462 & 1821 & iulie & 17 & Scrisoarea lui Hăjdău către domn & românesc \\
\hline 463 & 1814 & octombrie & 6 & Scrisoarea lui Veisa către Codreanu ${ }^{128}$ & " \\
\hline 464 & 1812 & aprilie & 1 & Chitanța de 1.000 de lei a lui Veisa & " \\
\hline 465 & 1813 & decembrie & 31 & $\begin{array}{l}\text { Scrisoarea lui Veisa către domn în pricina moșiei } \\
\text { Dolineni }\end{array}$ & $"$ \\
\hline 466 & 1818 & februarie & 21 & Scrisoarea lui Veisa către $<$ Măcărescu $>^{129}$ & $"$ \\
\hline 467 & 1818 & martie & 17 & Scrisoarea lui Veisa către $<$ Feodor $>{ }^{130}$ Măcărescu ${ }^{131}$ & ” \\
\hline 468 & 1819 & mai & 23 & $\begin{array}{l}\text { Declarația dată lui T. Cazimir în pricina lui } \\
\text { Costache }\end{array}$ & " \\
\hline 469 & 1812 & aprilie & 1 & $\begin{array}{l}\text { Foiae de împărțeală între <membrii > neamului } \\
\text { Cocorăscu }\end{array}$ & copie românească \\
\hline 470 & 1819 & mai & 2 & $\begin{array}{l}\text { Cartea lui Scarlat Calimah voievod prin care } \\
\text { întărește schimbul între Petrino și F. Balș }\end{array}$ & " \\
\hline
\end{tabular}

\footnotetext{
${ }^{120}$ Boga (1929a), p. 75-77, nr. XLVI.

${ }^{121}$ În text: „Ghișcă”.

122 „ofițer de cavalerie (inferior)”.

${ }^{123}$ Ar putea fi o lectură greșită, în loc de: „Miron” (vezi documentul următor).

${ }^{124}$ În text: „Moraru”.

${ }^{125}$ Probabil, greșeală: în loc de „turcesc”.

${ }^{126} \mathrm{MEF}$, VI, p. 140-142, nr. 45 (în orig.: „Vasilisa”).

${ }^{127}$ În text, data greșită: „1696 (7104)”. MEF, IV, p. 262-263, nr. 117.

${ }^{128}$ Boga (1928b), p. 27-28, nr. XXIX.

${ }^{129}$ Numele destinatarului nu se găsește în textul publicat. Cred că această scrisoare este cea din 11 februarie 1818, trimisă din Iași, la Chișinău, de Mihai Veisa în pricina unor moșii (Boga, 1928b, p. 44-45, nr. LII).

${ }^{130}$ În text: „P.”.

${ }^{131}$ Boga (1928b), p. 46-47, nr. LVI.
} 


\begin{tabular}{|c|c|c|c|c|c|}
\hline 471 & 1818 & aprilie & 25 & Carte de împărțeală între frații Veisa & $"$ \\
\hline 472 & - & - & - & $\begin{array}{l}\text { Cincizeci și două }(52) \text { note diverse, casnice, cu } \\
\text { privire la economia casnică }\end{array}$ & românesc \\
\hline 473 & - & - & - & Statul de serviciu al lui Ioan Hăjdău & rusesc \\
\hline 474 & - & - & - & $\begin{array}{l}\text { Scrisoarea către I. Stefanovici în chestiuni de } \\
\text { judecată }\end{array}$ & românesc \\
\hline 475 & 1858 & octomrbie & 17 & Scrisoarea Valeriei Hajdău către I. Hajdău & rusesc \\
\hline 476 & 1854 & aprilie & 7 & Scrisoarea" & $"$ \\
\hline 477 & $\frac{7221}{1714}$ & februarie & 20 & $\begin{array}{l}\text { Cartea lui Nicolae Alexandru voeivod, dată lui } \\
\text { Antiohie Jora, ca să aducă oameni străini }\end{array}$ & $\langle\text { rusesc }\rangle^{132}$ \\
\hline 478 & $\frac{7223}{1715}$ & martie & 29 & $\begin{array}{l}\text { Cartea lui Nicolae Alexandru voeivod, dată lui } \\
<\text { Iosâp }>{ }^{133} \text { vel căpitan de Hotin, pentru moșia } \\
\text { Ciabrăul }^{134}\end{array}$ & $\begin{array}{l}\text { românesc, cu trad. } \\
\text { rusească }\end{array}$ \\
\hline 479 & $\frac{7219}{1710}$ & noiembrie & 20 & $\begin{array}{l}\text { Zapisul lui Leon Adam către Antiohie Jora în } \\
\text { chestia unor datorii }\end{array}$ & $"$ \\
\hline 480 & $\frac{7206}{1698}$ & iulie & 8 & $\begin{array}{l}\text { Zapisul starostelui de Iași, Sava, pentru satul } \\
\text { Ciabrăul }\end{array}$ & " \\
\hline 481 & $\frac{7179}{1671}$ & iulie & 17 & $\begin{array}{l}\text { Cartea lui Duca voievod, dată lui Gavril Brăescul, } \\
\text { pentru satul Ceabrăul, < }<\text { din ținutul Hotin }>^{135}\end{array}$ & $\begin{array}{l}\text { românesc, copie, cu } \\
\text { trad. rusească }\end{array}$ \\
\hline 482 & - & - & - & Mai multe izvoade cu actele familiei Brăescul. & românesc \\
\hline $\begin{array}{l}482 \\
136\end{array}$ & $\frac{7206}{1698}$ & iulie & 1 & $\begin{array}{l}\text { Zapisul lui Gavril Brăescul pentru vînzarea moșiei } \\
\text { Ciabrăul }\end{array}$ & copie, cu trad. rusească \\
\hline 484 & 1839 & ianuarie & 30 & $\begin{array}{l}\text { Zapis de partea ce se dă lui Petre Jumica din averea } \\
\text { părintească. }\end{array}$ & $\begin{array}{l}\text { românesc, cu trad. } \\
\text { rusească }\end{array}$ \\
\hline 485 & 1825 & februarie & 6 & Zapisul lui Ștefan Spânu pentru o casă & $\begin{array}{l}\text { românesc, cu trad. } \\
\text { rusească }\end{array}$ \\
\hline 486 & 1839 & ianuarie & 31 & Diata lui Ilie Danu & " \\
\hline 487 & 1728 & august & 16 & Împărțeala pămînturilor lui Ilie Spânu & ” \\
\hline 488 & 1811 & martie & 25 & Diata lui Ilie Danu $^{137}$ & " \\
\hline 489 & $\frac{7178}{1669}$ & octombrie & 25 & $\begin{array}{l}\text { Zapisul lui Simion prin care vinde o parte din } \\
\text { Verejeni, <din ținutul Orhei> }\end{array}$ & românesc \\
\hline 490 & 1819 & martie & 20 & $\begin{array}{l}\text { Zapisul lui Ioan Cazimir prin care vinde a opta } \\
\text { parte din Medveja, }<\text { din ținutul Hotin }>138\end{array}$ & ” \\
\hline 491 & 1839 & - & - & $\begin{array}{l}\text { Chitanțe de primirea cîștiurilor de la moșiile } \\
\text { Sfântului Mormânt ( } 85 \text { piese, opt zeci și cinci) }\end{array}$ & $\begin{array}{l}\text { românesc, cu trad. } \\
\text { rusească }\end{array}$ \\
\hline 492 & 1838 & martie & 8 & $\begin{array}{l}\text { Scrisoarea lui Mihel Daniel către egumen în chestia } \\
\text { cîștiurilor }\end{array}$ & $\begin{array}{l}\text { grecesc, cu trad. } \\
\text { rusească }\end{array}$ \\
\hline $\begin{array}{l}492 \\
139\end{array}$ & 1837 & octombrie & 19 & Idem, în chestia trimiterii unei sume de bani & " \\
\hline 493 & 1837 & mai & 17 & $\begin{array}{l}\text { Scrisoarea lui <Başotă }{ }^{140} \text { către Cervenvodali în } \\
\text { chestia cîștiului }\end{array}$ & rusesc \\
\hline 494 & 1837 & aprilie & 2 & $\begin{array}{l}\text { Scrisoarea lui Grigorovici către Vasiliu pentru niște } \\
\text { bani }\end{array}$ & românesc \\
\hline 495 & 1835 & octombrie & 10 & $\begin{array}{l}\text { Contracte de arendare ale moșiilor Sfîntului } \\
\text { Mormînt }\end{array}$ & $\begin{array}{l}\text { rusești, patruzeci și opt } \\
\text { piese }\end{array}$ \\
\hline 496 & 1835 & august & 20 & $\begin{array}{l}\text { Contracte de arendare ale moșiilor Sfîntului } \\
\text { Mormînt }\end{array}$ & rusești, cinci piese \\
\hline
\end{tabular}

${ }^{132}$ Greșit, în loc de: „românesc”.

${ }^{133}$ În text: „Osip”.

${ }^{134} \mathrm{MEF}$, VIII, p. $27-28$, nr. 9.

${ }^{135}$ Boga (1930c), p. 170-171, nr. XXXIV; MEF, VI, p. 67-69, nr. 17.

${ }^{136}$ Număr dublat.

${ }^{137}$ Boga (1929a), p. 27-28, nr. XX.

${ }^{138}$ Boga (1929a), p. 37, nr. XXVII.

${ }^{139}$ Număr dublat.

${ }^{140}$ În text: „Bazaca”. Numele, Bașotă, a fost citit greșit în mai multe locuri din opis. 


\begin{tabular}{|c|c|c|c|c|c|}
\hline 497 & 1888 & august & 6 & $\begin{array}{l}\text { Tablouri de cele vândute în cursul anilor 1836-37 } \\
\text { din proprietățile Sfîntului Mormînt }\end{array}$ & rusesc, dosar de 55 file \\
\hline 498 & 1812 & iulie & 24 & $\begin{array}{l}\text { Zapisul de vînzare a lui <Donici }{ }^{141} \text { pentru un loc } \\
\text { de Vărzărești }\end{array}$ & rusesc \\
\hline 499 & 1812 & iulie & 24 & Zapisul lui Colța prin care vinde un loc la Vărzărești & " \\
\hline 500 & 1812 & august & 7 & $\begin{array}{l}\text { Zapisul lui Ștefan Popa prin care vinde o parte din } \\
<\text { bătrînul }{ }^{142} \text { Șchiopu }\end{array}$ & " \\
\hline 501 & 1812 & iulie & 24 & $\begin{array}{l}\text { Zapisul lui <Jărdan > }{ }^{143} \text { Iordan pentru măsurat } \\
\text { locului din < bătrînul > Vlad }\end{array}$ & ” \\
\hline 502 & 1869 & septembrie & 16 & Statu $<\mathrm{tu}>1$ personal al lui Daniil Timoftin & ” \\
\hline 503 & " & ” & " & Certificat de paupertate dat lui Daniil Timoftin & ” \\
\hline 504 & 1875 & aprilie & 5 & Opinia separată a lui Dobrov în pricina lui Barbalat & ” \\
\hline 505 & 1873 & noiembrie & 10 & $\begin{array}{l}\text { Copia adresei către Administrația Financiară în } \\
\text { pricina lui }\langle\text { Plitos }>144\end{array}$ & ” \\
\hline 506 & 1872 & septembrie & 13 & Chitanța de 504 ruble a lui „Poerschi” & ” \\
\hline 507 & - & - & - & $\begin{array}{l}\text { Zapis de vînzare a lui „Hasov” pentru un loc la } \\
\text { Cobâlca }\end{array}$ & ” \\
\hline 508 & 1812 & iulie & 24 & Socoteala strîngerilor din $\langle\ldots\rangle^{145}$ & ” \\
\hline 509 & 1833 & martie & 24 & $\begin{array}{l}\text { Planul locului din orașul Chișinău de pe strada } \\
\text { Izmailului }\end{array}$ & ” \\
\hline 510 & 1812 & august & 24 & Chitanța lui Dimitrie Pacu de 500 ruble & ” \\
\hline 511 & 1823 & februarie & 21 & Registru de averea rămasă după moartea lui Pacu & ” \\
\hline 512 & 1832 & noiembrie & 4 & Polița de 77 ruble a lui Doni & grecesc, cu trad. rus. \\
\hline 513 & 1857 & mai & 15 & $\begin{array}{l}\text { Raportul generalului Rusanov în pricina nepoatei } \\
\text { sale minore }\end{array}$ & rusească \\
\hline 514 & $\frac{7178}{1669}$ & octombrie & 16 & $\begin{array}{l}\text { Referatul boierilor în pricina moșiei <Tribisăuți, din } \\
\text { ținutul Hotin> }{ }^{146}\end{array}$ & $\begin{array}{l}\text { românesc, cu trad. } \\
\text { rusească }\end{array}$ \\
\hline 515 & - & - & - & $\begin{array}{l}\text { Referatul pîrcălabilor de Hotin în pricina moșiei } \\
<\text { Tribisăuți, din ținutul Hotin }>147\end{array}$ & ” \\
\hline 516 & $<1809\rangle$ & iunie & 9 & $\begin{array}{l}\text { Mărturia lui Constantin Leondar sluger în chestia } \\
\text { moșiilor Cantacuzinilor din Hotin } 148\end{array}$ & ” \\
\hline 517 & - & - & - & $\begin{array}{l}\text { Mărturia locuitorilor din <Tribisăuți> privitoare la } \\
\text { proprietatea acelei moșii }\end{array}$ & ” \\
\hline 518 & 1850 & aprilie & 8 & Mărturia cu privire la moșiile familiei Cantacuzino & ” \\
\hline 519 & $\frac{7159}{1651}$ & august & 22 & Mărturia hotarnică a <moșiei> Văscăuți ${ }^{149}$ & ” \\
\hline 520 & $\frac{7168}{1660}$ & mai & 15 & $\begin{array}{l}\text { Chitanța lui Turcuman pentru } 22 \text { lei împrumutați } \\
\text { de la Iordache vistiernic } \\
150\end{array}$ & ” \\
\hline 521 & $\frac{7169}{1661}$ & octombrie & 28 & $\begin{array}{l}\text { Zapis de vînzare a lui Turcuman prin care vinde o } \\
\text { bucată din Vărtop }^{151}\end{array}$ & ” \\
\hline 522 & $\frac{7169}{1660}$ & octombrie & 28 & $\begin{array}{l}\text { Cartea lui Ștefan voievod prin care întărește } \\
\text { cumpărătura lui Iordache <Cantacuzino> vistiernic } \\
<\text { în satul Demideni, din ținutul Hotin }>152\end{array}$ & " \\
\hline
\end{tabular}

\footnotetext{
${ }^{141}$ În text: „Donică”.

${ }^{142}$ Aici, și în alte locuri, a fost dactilografiat: „bătu”, în loc de „bătrînul”.

${ }^{143}$ În text: „Iordan”.

${ }^{144}$ În text: „Pitlis”.

${ }^{145}$ Rezumat neterminat.

${ }^{146}$ În text, greșit: „Pribicăuți”. Boga (1938a), p. 26-28, nr. IX.

${ }^{147}$ Boga (1938a), p. 81-83, nr. XXXI (mărturie hotarnică făcută de Coste Chirilovici pîrcălab de Hotin și de Ion căpitan).

${ }^{148}$ În text, dată greșită: „1509”.

${ }^{149}$ Boga (1929d), p. 47-48, nr. XLIV.

${ }^{150}$ Boga (1932c), p. 248, nr. V.

${ }^{151}$ Boga (1932b), p. 316-317, nr. I.

${ }^{152}$ Boga (1930c), p. 145-146, nr. X.
} 


\begin{tabular}{|c|c|c|c|c|c|}
\hline 523 & $\frac{7170}{1662}$ & februarie & 25 & $\begin{array}{l}\text { Zapisul lui Costin Liciul prin care vinde o bucată de } \\
\text { loc din Demideni }{ }^{153}\end{array}$ & $"$ \\
\hline 524 & - & aprilie & 14 & $\begin{array}{l}\text { Zapisul lui Stănescu pentru primirea unor } \\
\text { documente }\end{array}$ & $"$ \\
\hline 525 & $\frac{7170}{1662}$ & martie & 9 & $\begin{array}{l}\text { Cartea Divanului Moldovei prin care întărește } \\
\text { vînzarea lui Constantin Liciul }\end{array}$ & " \\
\hline 526 & $\frac{7170}{1662}$ & martie & 12 & $\begin{array}{l}\text { Cartea lui Istratie Dabija voievod prin care întărește } \\
\text { vînzarea lui Constantin Liciul < din satul Demideni, } \\
\text { ținutul Hotin }>154\end{array}$ & " \\
\hline 527 & $\frac{7173}{1665}$ & aprilie & 15 & $\begin{array}{l}\text { Cartea lui Istratie Dabija voievod prin care îi } \\
\text { întărește }<\text { stăpînirea }>{ }^{155} \text { lui Constantin Liciul }<s ̦ i \\
\text { soției sale, Antimia, peste jumătate din satul } \\
\text { Demideni }>\end{array}$ & $"$ \\
\hline 528 & $\frac{7175}{1667}$ & ianuarie & 22 & $\begin{array}{l}\text { Zapisul lui Toader Pisoschi prin care vinde o parte } \\
\text { lui Dimideni }{ }^{157}\end{array}$ & " \\
\hline $\begin{array}{c}529 \\
158\end{array}$ & $\frac{7175}{1666}$ & noiembrie & 9 & $\begin{array}{l}\text { Zapisul lui Ion Pisoțchi prin care se învoiește cu } \\
\text { sora sa, Antimia } 159\end{array}$ & $\begin{array}{l}\text { românesc, cu trad. } \\
\text { rusească }\end{array}$ \\
\hline 530 & $\frac{7175}{1667}$ & ianuarie & 30 & $\begin{array}{l}\text { Cartea }<\text { mitropolitului }>{ }^{160} \text { Ghedeon prin care se } \\
\text { întărește vînzarea lui Ion Pisoschi }{ }^{161}\end{array}$ & ” \\
\hline 531 & $\frac{7178}{1669}$ & octombrie & 16 & Mărturia hotarnică a satului <Tribisăuți> ${ }^{162}$ & ” \\
\hline 532 & 1809 & aprilie & 1 & $\begin{array}{l}\text { Izvod de scrisorile ce a depus Costachi Conachi pe } \\
\text { moșia Demideni }\end{array}$ & $”$ \\
\hline 533 & 1810 & iulie & 19 & $\begin{array}{l}\text { Cartea Divanului Cnejiei Moldovei prin care i se } \\
\text { întărește stăpînirea moșiei Demideni }\end{array}$ & $"$ \\
\hline 534 & 1811 & martie & 29 & $\begin{array}{l}\text { Porunca Cnejiei Moldovei către stolnicul Ioan } \\
\text { Cheșcu }\end{array}$ & $"$ \\
\hline 535 & 1771 & iulie & 27 & Ordinul lui Rumianțov dat lui Costachi Conachi & " \\
\hline 536 & 1811 & iunie & 20 & $\begin{array}{l}\text { Cartea Cnejiei Moldovei în pricina lui Costachi } \\
\text { Conachi }\end{array}$ & $”$ \\
\hline 537 & 1812 & august & 25 & $\begin{array}{l}\text { Cererea lui Costachi Conachi în pricina moșiei } \\
\text { Tribisăuți }\end{array}$ & românesc \\
\hline 538 & 1812 & februarie & 8 & Harta satelor <Mandicăuți $>{ }^{163}$, „Carlacani”164 & ” \\
\hline 539 & - & - & - & Document putrezit & 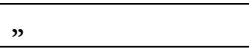 \\
\hline 540 & 1823 & aprilie & 17 & $\begin{array}{l}\text { Copie de pe hotărîrea comisiei hotărîrilor a moșiei } \\
\text { Corjeuții }\end{array}$ & " \\
\hline 541 & 1811 & august & 11 & Învoiala între frații Hajdău & copie \\
\hline 542 & - & - & - & Lista de domnii Moldovei, cu anii <de domnie $>$ & românesc \\
\hline 543 & - & - & - & Socoteala cu diverse cumpărături și prețuri & ” \\
\hline 544 & 1850 & mai & 26 & $\begin{array}{l}\text { Protestul lui Ioan Hajdău în pricina satului } \\
\text { Ceponos }\end{array}$ & rusesc \\
\hline 545 & 1875 & februarie & 8 & Zapisul de vînzare a lui „T,ambali” & românesc \\
\hline 546 & 1832 & noiembrie & 25 & Chitanța de un împrumut & ” \\
\hline 547 & 1836 & aprilie & 27 & Sumă de bani luați de Ion Hajdău & 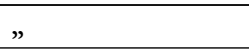 \\
\hline
\end{tabular}

${ }^{153} \operatorname{Boga}(1932 b)$, p. 317-318, nr. II.

${ }^{154}$ Boga (1930c), p. 149-150, nr. XIV; MEF, V, p. 59-62, nr. 18.

${ }^{155}$ În text, greșit: „vînzarea”.

${ }^{156}$ Boga (1930c), p. 151-152, nr. XVI; MEF, V, p. 124-126, nr. 48.

${ }^{157}$ Boga (1932b), p. 321-322, nr. VII (zapisul nu este de vînzare, ci de schimb cu marele spătar Toderașco Cantacuzino).

${ }^{158}$ Numerele 539-579 au fost intercalate între numerele 1046-1047, p. 42-44 din opis.

${ }^{159}$ Boga (1932b), p. 320-321, nr. VI (schimb de moșii, între Vârtop și Demideni); MEF, V, p. 177-179, nr. 71.

${ }^{160}$ În text: „episcopului”.

${ }^{161}$ Boga (1933), p. 65-66, nr. I.

${ }^{162}$ În text: „Pribicăuți”. Vezi și mai sus, nr. 514.

163 În text: „Handicăuți”.

${ }^{164}$ Poate „Caracușeni”. 


\begin{tabular}{|c|c|c|c|c|c|}
\hline 548 & 1809 & august & 17 & $\begin{array}{l}\text { Porunca Divanului Cnejiei Moldovei către } \\
\text { Părcălabia Hotinului }\end{array}$ & ” \\
\hline 549 & 1816 & februarie & 10 & $\begin{array}{l}\text { Hotărîrea Departamentului 1-i al Basarabiei în } \\
\text { pricina lui Alexandru Panait }\end{array}$ & $\begin{array}{l}\text { românesc, cu trad. } \\
\text { rusească }\end{array}$ \\
\hline 550 & - & - & - & Lista mitropoliților Moldovei & românesc \\
\hline 551 & 1836 & aprilie & 30 & $\begin{array}{l}\text { Cererea lui Gh. Dimitriu în pricina moșiei dein } \\
\text { județul Hotin }\end{array}$ & rusesc \\
\hline 552 & $\begin{array}{l}<1812> \\
165\end{array}$ & mai & 28 & $\begin{array}{l}\text { Scrisoarea <Valeriei> Hajdău către nepotul ei, Ioan } \\
\text { Hajdău }\end{array}$ & $"$ \\
\hline 553 & 1819 & ianuarie & 15 & $\begin{array}{l}\text { Scrisoarea lui <Boleslav> Hajdău către Ioan } \\
\text { Hajdău }^{166}\end{array}$ & românesc \\
\hline 554 & 1856 & iulie & - & Lista de oamenii ce lucrează boierescul & ” \\
\hline 555 & 1845 & aprilie & 7 & $\begin{array}{l}\text { Vechilemeaua, dată de mănăstirea Slatina, lui } \\
\text { „Volciu” }\end{array}$ & ” \\
\hline 556 & 1813 & aprilie & 26 & $\begin{array}{l}\text { Cererea lui Neculai „Iecaiului” către Judecătoria } \\
\text { ținutului Eși }\end{array}$ & ” \\
\hline 557 & 1842 & martie & 18 & $\begin{array}{l}\text { Zapisul lui Dumitrachi Ghițescu pentru o vînzare } \\
<\mathrm{a}>\text { lui Ion }\end{array}$ & $\begin{array}{l}\text { românesc, cu trad. } \\
\text { rusească }\end{array}$ \\
\hline 558 & 1811 & aprilie & 26 & $\begin{array}{l}\text { Divanul Cnejiei Moldovei către domn în pricina lui } \\
\text { Ion Bărlădeanul }\end{array}$ & românesc \\
\hline 559 & 1815 & octombrie & 30 & $\begin{array}{l}\text { Hotărîrea Departamentului } 1 \text { al oblastiei Basarabia } \\
\text { în pricina lui Constantin Cucicov }\end{array}$ & ” \\
\hline 560 & 1819 & martie & 8 & $\begin{array}{l}\text { Jalba lui D. Costin în pricina moșiilor din județul } \\
\text { Hotin }\end{array}$ & ” \\
\hline 561 & 1861 & septembrie & 7 & Scrisoarea lui A. Ruso către Emil Alexandrovici & rusesc \\
\hline 562 & 1783 & noiembrie & 9 & $\begin{array}{l}\text { Zapisul lui Lupu „Tutescu” prin care face danie lui } \\
\text { Neculai }\end{array}$ & " \\
\hline 563 & 1817 & martie & 15 & $\begin{array}{l}\text { Zapisul între Fadeu Hajdău și tot neamul Hajdeilor } \\
\text { de felul cum s-au așezat }\end{array}$ & românesc \\
\hline 564 & 1833 & noiembrie & 22 & Contract pentru moșiile Sancauții etc. & $\begin{array}{l}\text { românesc, cu trad. } \\
\text { rusească }\end{array}$ \\
\hline 565 & 1863 & iunie & 20 & $\begin{array}{l}\text { Adresă către Ciolac de la o casă de comerț, însoțită } \\
\text { de o factură }\end{array}$ & german \\
\hline 566 & 1823 & decembrie & 27 & $\begin{array}{l}\text { Învoiala între Alexandru Ghica și Nicolae } \\
\text { Trohin }^{167}<\text { pentru > schimbul moșiilor. }\end{array}$ & $\begin{array}{l}\text { românesc, cu trad. } \\
\text { rusească }\end{array}$ \\
\hline 567 & 1823 & ” & 27 & Idem & $"$ \\
\hline 568 & 1809 & octombrie & 22 & $\begin{array}{l}\text { Propunerea lui Crasno Milașevici către Divan în } \\
\text { chestia moșiilor din Hotin }\end{array}$ & " \\
\hline 569 & 1860 & august & - & Venitul moșiei Anadol & 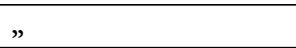 \\
\hline 570 & 1809 & noiembrie & 27 & $\begin{array}{l}\text { Cartea Divanului Cneziei Moldovei în pricina } \\
\text { moșiilor din Hotin }\end{array}$ & " \\
\hline 571 & 1810 & septembrie & 5 & $\begin{array}{l}\text { Ordinul Divanului Cneziei Moldovei către } \\
\text { Costachi Ghica în pricina moșiilor din Hotin }\end{array}$ & " \\
\hline 572 & 1810 & august & 19 & $\begin{array}{l}\text { Adresa lui Crasno Milașevici către Divan în pricina } \\
\text { moșiilor din Hotin }\end{array}$ & ” \\
\hline 573 & 1819 & decembrie & 18 & $\begin{array}{l}\text { Scrisoarea lui Ioan Sturza, < din Chișinău> către } \\
\text { Măriuța Ghica, <la Iași > } 168\end{array}$ & ” \\
\hline 574 & $\frac{7170}{1662}$ & mai & 15 & $\begin{array}{l}\text { Cartea șoltuzului de Hotin prin care întărește o } \\
\text { vînzare }\end{array}$ & ” \\
\hline 575 & $\frac{7174}{1665}$ & noiembrie & 25 & $\begin{array}{l}\text { Cartea lui Duca voievod în pricina de judecată a lui } \\
\text { Ion Pisoschi }{ }^{169}\end{array}$ & românesc cu trad. rus. \\
\hline
\end{tabular}

${ }^{165}$ În text, dată greșită: „28 mai 1812”; probabil este scrisoarea din 28 martie 1850 (Boga (1928b), p. 145, nr. CXIX).

${ }^{166}$ În text, data de an este greșită. Scrisoarea poate data din anii '40-'50 ai secolului al XIX-lea (vezi mai jos).

${ }^{167}$ În text: „Trihin”.

${ }^{168}$ În documentul publicat: „Ghijdeu”. Boga (1928b), p. 56, nr. LXXI.

${ }^{169}$ Boga (1930c), p. 155-156, nr. XIX. 


\begin{tabular}{|c|c|c|c|c|c|}
\hline 576 & $\begin{array}{l}<1777> \\
170\end{array}$ & ianuarie & 13 & $\begin{array}{l}\text { Zapisul lui Crucerescu pentru vînzarea unei părți } \\
\text { din Demideni }\end{array}$ & ” \\
\hline 577 & $\frac{7177}{1669}$ & mai & 28 & $\begin{array}{l}\text { Cartea lui Duca voievod <prin care întărește lui } \\
\text { Toader Pisoschi și altor rude ale acestuia stăpînirea } \\
\text { asupra unor părți din Demideni, pentru care a } \\
\text { avut> pricină cu Ștefan Stănescu }{ }^{171}\end{array}$ & " \\
\hline 578 & $\frac{7219}{1710}$ & octombrie & 14 & $\begin{array}{l}\text { Cartea lui Nicolae Alexandru voievod, dată lui } \\
\text { Gheorghe Pisoschi, pentru a-și căuta țiganii }{ }^{172}\end{array}$ & " \\
\hline 579 & 1771 & ianuarie & - & Izvod de zestre dată de Pisoschi fiicei sale ${ }^{173}$ & ” \\
\hline 580 & 1824 & mai & 30 & Spița de neam a familiei Brodschi & românesc \\
\hline 581 & $\frac{7157}{1649}$ & august & 2 & $\begin{array}{l}\text { Cartea dvornicului < de gloată, Neniul>, în pricina } \\
\text { moșiei Vascăuți, < din ținutul Hotin > }\end{array}$ & ” \\
\hline 582 & $\frac{7247}{1739}$ & martie & 18 & $\begin{array}{l}\text { Copie de pe }<\text { suretul }{ }^{175} \text { cărții lui Vasilie voievod } \\
\text { în pricina satului Hilișău }\end{array}$ & $\begin{array}{l}\text { românesc, cu trad. } \\
\text { rusească }\end{array}$ \\
\hline 583 & 1772 & iulie & 17 & Ordinul polcovnicului dat lui Andrei Golubei & rusesc. \\
\hline 584 & 1772 & iulie & 7 & $\begin{array}{l}\text { Ordinul locotenentului pentru aflarea satului } \\
\text { Sfișcăuții }\end{array}$ & românesc \\
\hline 585 & 1818 & octombrie & 16 & $\begin{array}{l}\text { Mărturia privitoare la satul Trinca, < din ținutul } \\
\text { Hotin> }\end{array}$ & $\begin{array}{l}\text { românesc, cu trad. } \\
\text { rusească }\end{array}$ \\
\hline 586 & 1820 & februarie & 23 & $\begin{array}{l}\text { Cartea lui Mihai }<\text { Suțu }>^{176} \text { voievod dată lui } \\
\text { Caraiman din satul Ionășeni }\end{array}$ & ” \\
\hline 587 & 1820 & mai & 14 & Mărturia sătenilor din „Telești” ${ }^{177}$ & " \\
\hline 588 & 1820 & octombrie & 20 & Spița neamului Doltaresc ${ }^{178}$ & " \\
\hline 589 & 1821 & martie & 8 & $\begin{array}{l}\text { Copie după hotărîrea Judecătoriei ținutului Hotin } \\
\text { în pricina moșiei }<\text { Stroești }>{ }^{179} \text {, din ținutul Hotin }\end{array}$ & " \\
\hline 590 & $\frac{7189}{1681}$ & mai & 20 & $\begin{array}{l}\text { Cartea lui Antonie Ruset voievod, dată lui Ionașcu } \\
\text { clucer, pentru satul Dușceni }\end{array}$ & $\begin{array}{l}\text { copie românească, cu } \\
\text { trad. rusească }\end{array}$ \\
\hline 591 & $\frac{7185}{1677}$ & iulie & 30 & $\begin{array}{l}\text { Cartea lui Antonie Ruset voievod, dată lui Ionașcu } \\
\text { clucer, p. satul Dușceni <şi pentru altele, din ținutul } \\
\text { Hotin }>\end{array}$ & $\begin{array}{l}<\text { neprecizat felul } \\
\text { actului }>\end{array}$ \\
\hline 592 & $\frac{7195}{1686}$ & decembrie & 17 & $\begin{array}{l}\text { Zapisul lui Andrei pentru vînzarea unei părți din } \\
\text { Hrițeni, <din ținutul Hotin> }\end{array}$ & românesc, cu trad. rus. \\
\hline 593 & $\frac{7212}{1704}$ & iulie & 5 & $\begin{array}{l}\text { Cartea lui Mihail Racoviță voievod, dată lui } \\
\text { Constantin cămăraș, pentru satul Lopatințiii }{ }^{181}\end{array}$ & $\begin{array}{l}\text { copie }<\text { românească }>\text { cu } \\
\text { trad. rus. }\end{array}$ \\
\hline 594 & $\frac{7220}{1712}$ & martie & 12 & $\begin{array}{l}\text { Cartea lui <Nicolae > Alexandru <Mavrocordat〉 } \\
\text { voievod, dată lui Lupul vistiernic, pentru moșia } \\
\text { Dușceni }^{182}\end{array}$ & ” \\
\hline 595 & 1818 & aprilie & 1 & $\begin{array}{l}\text { Scrisoarea lui Teodor Ciure pentru schimbul unei } \\
\text { moșii din Hotin cu Ioniță Iamandi }\end{array}$ & ” \\
\hline 596 & $\frac{7146}{1638}$ & august & 20 & $\begin{array}{l}\text { Suret de pe opisul lui Vasilie voievod, dat lui Vartic, } \\
\text { pentru satul Costeștii }\end{array}$ & ” \\
\hline
\end{tabular}

\footnotetext{
${ }^{170}$ În text, greșit: „1877”.

${ }^{171}$ Boga (1930c), p. 166-167, nr. XXIX.

${ }^{172} \mathrm{Boga}$ (1930a), p. 354, nr. IX.

${ }^{173}$ Boga (1928a), p. 8, nr. 9.

${ }^{174}$ Boga (1938a), p. 17-18, nr. IV.

${ }^{175}$ În text: „smetul”.

${ }^{176}$ În text, greșit: „Sturza”.

${ }^{177}$ Probabil, „Telenești”.

178 „Doltu”.

${ }^{179}$ În text: „Stroescul”.

${ }^{180}$ Boga (1930c), p. 174-175, nr. XXXVIII.

${ }^{181} \mathrm{MEF}$, VI, p. 219-221, nr. 85.

${ }^{182} \mathrm{MEF}$, VIII, p. 21 , nr. 1
} 


\begin{tabular}{|c|c|c|c|c|c|}
\hline 597 & $\frac{7173}{1665}$ & iunie & 29 & $\begin{array}{l}\text { Suret de pe împărțeala feciorilor lui Efrem } \\
\text { Hajdău }^{183}\end{array}$ & ” \\
\hline 598 & $\frac{7173}{1665}$ & mai & 27 & Împărțeala fraților Hajdău ${ }^{184}$ & " \\
\hline 599 & $\frac{7199}{1691}$ & martie & 5 & $\begin{array}{l}\text { Copie după cartea lui Constantin voievod, dată lui } \\
\text { Ioan, pentru Toporăuți }\end{array}$ & " \\
\hline 600 & $\frac{7205}{1697}$ & iulie & 27 & $\begin{array}{l}\text { Copie după zapisul lui Miron Stărcea pentru } \\
\text { împărțirea moșiilor lui }\end{array}$ & ” \\
\hline 601 & $\frac{7208}{1700}$ & ianuarie & 3 & $\begin{array}{l}\text { Zapisul lui Vasilie Hajdău pentru satul Pașcanții, } \\
\text { <din ținutul Hotin }>185\end{array}$ & ” \\
\hline 602 & $\frac{7209}{1701}$ & ianuarie & 12 & Copie de pe diata Mariei, fata lui Gheorghe Hajdău & ” \\
\hline 603 & $\frac{7209}{1701}$ & ianuarie & 13 & $\begin{array}{l}\text { Mărturia Anghelușei Stărcea pentru moșia } \\
\text { Tulbureni }^{186}\end{array}$ & ” \\
\hline 604 & 1736 & martie & 24 & Diata lui Vasilie Hajdău & rusesc \\
\hline 605 & 1746 & martie & 20 & Împărțeala țiganilor lui I. Hajdău & $\begin{array}{l}\text { românesc, cu trad. } \\
\text { rusească }\end{array}$ \\
\hline 606 & $\frac{7256}{1748}$ & ianuarie & 13 & Suret de pe scrisoarea lui Sandu Hajdău & $"$ \\
\hline 607 & $\frac{7267}{1755}$ & martie & 20 & Scrisoarea de învoială a lui Grigore Hajdău & $"$ \\
\hline 608 & - & - & - & $\begin{array}{l}\text { Mărturia lui Grigorie Hajdău pentru împărțirea } \\
\text { făcută }\end{array}$ & ” \\
\hline 609 & 1774 & aprilie & 12 & Diata lui Gheorghe Hajdău ${ }^{187}$ & ” \\
\hline 610 & - & aprilie & 1 & Învoiala între Gh. Hajdău și alți Hajdăi & $"$ \\
\hline 611 & 1773 & septembrie & 15 & Mărturia Ruxandrei Hajdău & ” \\
\hline 612 & 1773 & septembrie & 28 & $\begin{array}{l}\text { Cartea lui Dionisie al Hotinului }{ }^{188} \text { pentru } \\
\text { împărțirea lui Gh. Hajdău }\end{array}$ & $"$ \\
\hline 613 & 1779 & ianuarie & 6 & $\begin{array}{l}\text { Cartea Isprăvniciei Sucevei }{ }^{189} \text { pentru împărțeala lui } \\
\text { Gh. Hajdău }\end{array}$ & ” \\
\hline 614 & 1810 & iunie & 21 & Nota comisiei rănduite pentru moşiile din Hotin & ” \\
\hline 615 & 1810 & septembrie & 5 & $\begin{array}{l}\text { Cartea Divanului Cnejiei Moldovei pentru moșiile } \\
\text { lui }<\text { Iofce }>190\end{array}$ & $"$ \\
\hline 616 & 1812 & martie & 2 & $\begin{array}{l}\text { Cartea Divanului Cnejiei Moldovei către Părcălabia } \\
\text { de Hotin pentru satul Cărstineștii }\end{array}$ & ” \\
\hline 617 & 1815 & octombrie & 21 & $\begin{array}{l}\text { Mărturia dată lui Toader Hajdău pentru niște acte } \\
\text { vechi }\end{array}$ & ” \\
\hline 618 & 1817 & martie & 15 & Scrisoare de învoială între Hajdăi & ” \\
\hline 619 & 1814 & martie & 17 & Copie după un izvod de documente & 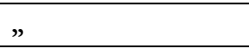 \\
\hline 620 & $\frac{7199}{1691}$ & iulie & 12 & Copie după scrisoarea lui Volcinschi & $"$ \\
\hline 621 & 1756 & iulie & 15 & Copie după tabula satului „Militiuți”191 & $\begin{array}{l}\text { latin, cu trad. } \\
\text { românească }\end{array}$ \\
\hline 622 & 1701 & ianuarie & 12 & Mărturia Mariei Hajdău pentru moșia Cârstineștii & românesc \\
\hline 623 & 1848 & mai & 19 & Tablă în care se trec zilele lucrătoare & $"$ \\
\hline 624 & 1842 & mai & 25 & Fragment dintr-o scrisoare a lui Dumitru & " \\
\hline
\end{tabular}

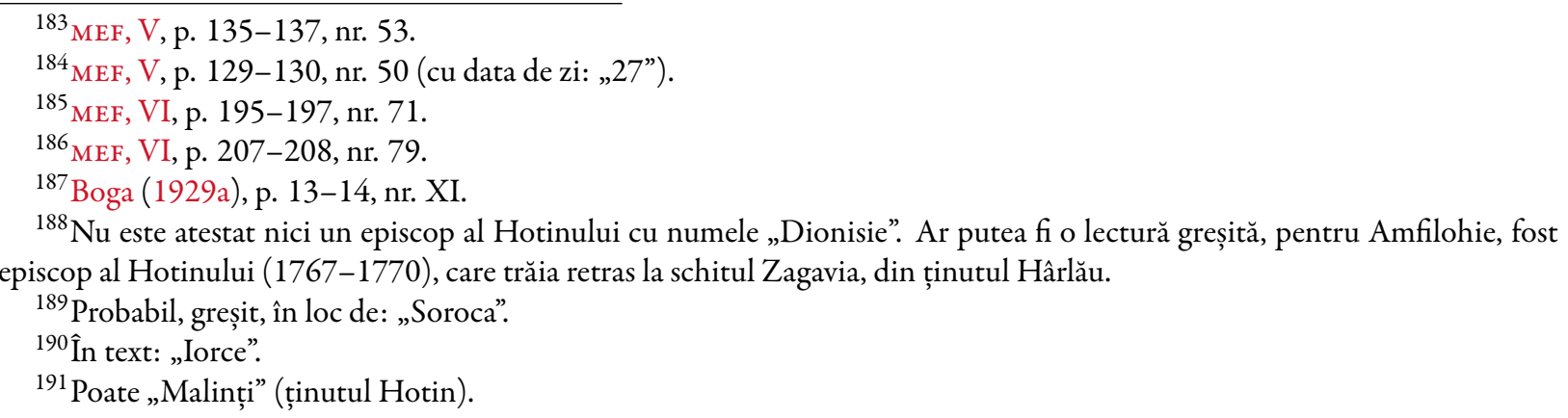




\begin{tabular}{|c|c|c|c|c|c|}
\hline 625 & 1850 & martie & 28 & $\begin{array}{l}\text { Scrisoarea Valeriei Hajdău, < aflată la Cârstinești>, } \\
\text { către Ionița Hajdău } 192\end{array}$ & ” \\
\hline $\begin{array}{c}625 \\
193\end{array}$ & 1850 & aprilie & 19 & Idem $^{194}$ & ” \\
\hline 626 & 1853 & martie & 18 & Idem $^{195}$ & ” \\
\hline 627 & 1809 & mai & 13 & $\begin{array}{l}\text { Scrisoarea lui Lupul Grigorie pentru vînzarea unei } \\
\text { părți din „Cerneți” }\end{array}$ & $"$ \\
\hline 628 & 1806 & martie & 20 & $\begin{array}{l}\text { Zapisul lui Lupu Grigorie pentru moșiile ce are în } \\
\text { Hotin }\end{array}$ & copie \\
\hline 629 & 1803 & iunie & 10 & $\begin{array}{l}\text { Mărturia mai multor boieri, dată lui Lupul } \\
\text { Nistoreanul, pentru moșiile tatălui său }\end{array}$ & $"$ \\
\hline 630 & 1813 & martie & 15 & Mărturia mai multor boieri pentru frații Grigorii & românesc \\
\hline 631 & 1826 & - & - & $\begin{array}{l}\text { Copie după hotărîrea cancelariei hot<ărniciilor > în } \\
\text { pricina moșiilor stat<ului> din Hotin }\end{array}$ & românesc, copie \\
\hline 632 & 1850 & august & 15 & $\begin{array}{l}\text { Zapisul fraților Grigorii prin care vînd un loc în } \\
\text { Hotin }\end{array}$ & românesc \\
\hline 633 & 1810 & octombrie & 28 & $\begin{array}{l}\text { Cartea Divanului Cnejiei Moldovei în pricina } \\
\text { fraților Grigorii }\end{array}$ & ” \\
\hline 634 & 1817 & martie & 4 & $\begin{array}{l}\text { Mărturie dată lui Mihalache Verdeș că e frate cu } \\
\text { Constantin Verdeș }\end{array}$ & copie românească \\
\hline 635 & 1815 & mai & 2 & Scrisoarea lui Gh. Tabară către pitarul Feodosiu & ” \\
\hline 636 & 1818 & martie & 15 & $\begin{array}{l}\text { Adeverința lui Constantin Cernescu dată lui } \\
\text { Mihalache Verdeș }\end{array}$ & $"$ \\
\hline 637 & 1818 & martie & 5 & Act de învoială între frații Verdeș & " \\
\hline $\begin{array}{c}637 \\
196\end{array}$ & 1817 & martie & 4 & $\begin{array}{l}\text { Mărturie dată lui Mihail Verdeș că a fost frate cu } \\
\text { Constantin Verdeș }{ }^{197}\end{array}$ & " \\
\hline 638 & 1826 & - & - & Spița familiei lui Simion Rusanovschi & ” \\
\hline 639 & 1809 & aprilie & - & $\begin{array}{l}\text { Cartea Divanului Cnejiei Moldovei în pricina } \\
\text { moșiei Carlacăul, <din ținutul Hotin> }\end{array}$ & ” \\
\hline 640 & 1820 & mai & 28 & $\begin{array}{l}\text { Răspunsul lui Coste Vasiliu în pricina moșiei } \\
\text { Vârnovița,<din ținutul Hotin> }\end{array}$ & ” \\
\hline 641 & 1821 & ianuarie & 11 & $\begin{array}{l}\text { Răspunsul lui Coste Vasiliu în pricina dobîndei ce } \\
\text { are a plăti }\end{array}$ & ” \\
\hline 642 & 1821 & ianuarie & 11 & $\begin{array}{l}\text { Hotărîrea arbitrilor în chestia lui Vasiliu cu } \\
<\text { Volcinschi }>198\end{array}$ & $”$ \\
\hline 643 & 1814 & aprilie & 24 & $\begin{array}{l}\text { Jalba lui Constantin Vasiliu către Pîrcălăbie pentru } \\
\text { moșia Vărnovița }\end{array}$ & ” \\
\hline 644 & 1818 & februarie & 1 & $\begin{array}{l}\text { Porunca Pîrcălăbiei pentru a aduce la jurămînt pe } \\
\text { niște boieri }\end{array}$ & $”$ \\
\hline 645 & 1812 & iulie & 3 & $\begin{array}{l}\text { Cartea Divanului Cnejiei Moldovei către Pîrcălăbia } \\
\text { Hotin pentru o parte a moșiei Vărnovița }\end{array}$ & ” \\
\hline 646 & 1814 & aprilie & 8 & $\begin{array}{l}\text { Jalba lui Constantin Vasiliu către Pîrcălăbie în } \\
\text { pricina lui cu <Volcinschi〉 }\end{array}$ & românesc, copie \\
\hline 647 & 1814 & aprilie & 24 & Idem & ” \\
\hline 648 & - & - & - & $\begin{array}{l}\text { Scrisoare către boierul Mărzacu în pricina cu } \\
<\text { Volcinschi }>\end{array}$ & românesc \\
\hline 649 & $\frac{7254}{1746}$ & iulie & 20 & $\begin{array}{l}\text { Cartea lui Ioan Nicolae voievod, dată lui Iordache } \\
\text { Cantacuzino, pentru satul Părjolta, <din ținutul } \\
\text { Iași> }\end{array}$ & copie românească \\
\hline
\end{tabular}

${ }^{192}$ În textul publicat: „Ghijdeu” (la fel în cele două scrisori care urmează). Boga (1928b), p. 145, nr. CXCIX.

${ }^{193}$ Număr dublat.

${ }^{194}$ Boga (1928b), p. 146, nr. CC (cu data de zi: „14”).

${ }^{195}$ Boga (1928b), p. 146-147, nr. CCI.

${ }^{196}$ Număr dublat.

${ }^{197}$ Vezi și nr. 634.

${ }^{198}$ În text: „Colcinschi” (la fel și mai jos, în rezumatele nr. 646, 647). 


\begin{tabular}{|c|c|c|c|c|c|}
\hline 650 & 1815 & - & - & $\begin{array}{l}\text { Izvod de dijma ce s-au primit de la sătenii de pe } \\
\text { moșia Costiceni }\end{array}$ & românesc \\
\hline 651 & 1817 & noiembrie & 25 & $\begin{array}{l}\text { Porunca <Pîrcălăbia de> Hotin către același în } \\
\text { pricina moșiei Costiceni }\end{array}$ & copie românească \\
\hline 652 & $\frac{7159}{1651}$ & mai & 18 & $\begin{array}{l}\text { Cartea lui Vasilie voievod, dată lui Gavrilaș vel } \\
\text { logofăt, pentru a lua doi boi, < drept gloabă }>\text {, de la } \\
<\text { Dudul }>^{199} \text { din Hotin }{ }^{200}\end{array}$ & românesc \\
\hline 653 & - & - & - & $\begin{array}{l}\text { Porunca Pîrcălăbiei către ocolașii Prutului de Sus, } \\
\text { pentru moșia Costiceni }\end{array}$ & ” \\
\hline 654 & 1815 & noiembrie & 23 & $\begin{array}{l}\text { Vechilimeaua dată de Andronache Grierosul dată } \\
\text { lui Mihalache Goian }\end{array}$ & ” \\
\hline 655 & 1816 & aprilie & 18 & $\begin{array}{l}\text { Porunca Părcălăbiei Hotin către ocolașii de } \\
\text { Ghilavăț în pricina moșiei Cruhlic }\end{array}$ & ” \\
\hline 656 & 1817 & noiembrie & 26 & Zapisul lui Vasilie Grierosul pentru moșia Costiceni & ” \\
\hline 657 & 1816 & noiembrie & 29 & $\begin{array}{l}\text { Zapisul lui Mihalache Goian pentru vînzarea } \\
\text { moșiei Cruhlic }\end{array}$ & copie românească \\
\hline 658 & 1811 & decembrie & 15 & $\begin{array}{l}\text { Cartea Divanului Cnejiei Moldovei pentru moşia } \\
\text { Costiceni }\end{array}$ & românesc \\
\hline 659 & 1810 & mai & 10 & $\begin{array}{l}\text { Cartea Divanului Cnejiei Moldovei pentru moșia } \\
\text { Costiceni }\end{array}$ & ” \\
\hline 660 & 1820 & martie & 15 & $\begin{array}{l}\text { Vechilimea dată lui Vasilie Roschip <și> lui Vasilie } \\
\text { Tușinschi }\end{array}$ & ” \\
\hline 661 & 1819 & iulie & 20 & $\begin{array}{l}\text { Mărturia lui Neculai și Ionița Perju dată lui Vasilie } \\
\text { Roschip }\end{array}$ & ” \\
\hline 662 & 1820 & martie & 16 & $\begin{array}{l}\text { Vechilimea dată lui Vasilie Roschip <și > lui Vasilie } \\
\text { Tuşinschi }\end{array}$ & $”$ \\
\hline 663 & $\frac{7276}{1768}$ & august & 26 & $\begin{array}{l}\text { Mărturia dată lui Ioan Onciul pentru socoteala cu } \\
\text { Iordache Perjul }\end{array}$ & copie \\
\hline 664 & 1774 & aprilie & 30 & $\begin{array}{l}\text { Scrisoarea brigadirului „Peritilman” în pricina } \\
\text { moșiei „Serbacov” } 01\end{array}$ & rusesc \\
\hline 665 & 1774 & februarie & 25 & $\begin{array}{l}\text { Cartea Divanului Cnejiei Moldovei către } \\
\text { Constantin Chirilovici ispravnicul ținutului Hotin } \\
\text { în pricina moșiei Citnicăul }\end{array}$ & românesc, copie \\
\hline 666 & 1773 & noiembrie & 10 & $\begin{array}{l}\text { Zapisul lui Gheorghe Hajdău și <a lui> Neculai } \\
\text { Lepădatu în pricina moșii lor din raia }\end{array}$ & românesc \\
\hline 667 & 1787 & martie & 13 & $\begin{array}{l}\text { Mărturia lui Anempodist ierodiaconul din Vorona } \\
\text { dată lui Macari }\end{array}$ & ” \\
\hline 668 & 1774 & aprilie & 30 & $\begin{array}{l}\text { Traducerea românească a actului înregistrat sub nr. } \\
664\end{array}$ & ” \\
\hline 669 & 1780 & ianuarie & 17 & $\begin{array}{l}\text { Izvod de mai multe scrisori luate de la Episcopia } \\
\text { Rădăuțului }\end{array}$ & $”$ \\
\hline 670 & 1787 & ianuarie & 20 & Mărturia lui Anempodist dată lui Andrei Boice & ” \\
\hline 671 & 1815 & octombrie & 21 & $\begin{array}{l}\text { Mărturia lui Andrei Boice în pricina împărțelei } \\
\text { moșiilor }\end{array}$ & copie \\
\hline 672 & 1817 & martie & 14 & $\begin{array}{l}\text { Învoiala între Toader Hajdău şi Gheorghe } \\
\text { „Dracu”202 }\end{array}$ & românesc \\
\hline 673 & 1823 & aprilie & 22 & $\begin{array}{l}\text { Danie dată de Manolache Volcinschi fiului său, } \\
\text { Ioan }^{203}\end{array}$ & ” \\
\hline 674 & 1825 & martie & 14 & $\begin{array}{l}\text { Contract de învoială între Ion Volcinschi și } \\
\text { Dimitrie Grigorescu }\end{array}$ & copie românească \\
\hline 675 & - & - & - & Spița neamului Andronic Badul & românesc \\
\hline
\end{tabular}

\footnotetext{
${ }^{199}$ În text: „David”.

${ }^{200}$ Boga (1929d), p. 35-36, nr. XXXIV.

${ }^{201}$ Poate „Șerbiceni” (ținutul Hotin).

${ }^{202}$ Poate „Dracea”.

${ }^{203}$ Boga (1929a), p. 57, nr. XXXIV.
} 


\begin{tabular}{|c|c|c|c|c|c|}
\hline 676 & 1823 & aprilie & 23 & Contract între Toader Volcinschi și Ioniță Badiul & ” \\
\hline 677 & 1823 & aprilie & 21 & $\begin{array}{l}\text { Vechilimeaua dată de Gh. Volcinschi lui P. } \\
\text { Vlahovici }\end{array}$ & " \\
\hline 678 & - & - & - & act turcesc. & \\
\hline 679 & - & - & - & act turcesc & \\
\hline 680 & 1827 & aprilie & 13 & $\begin{array}{l}\text { Jalba lui Pavalachi Palazov către Judecătoria } \\
\text { ținututului Hotin }\end{array}$ & românesc \\
\hline 681 & 1823 & februarie & 19 & $\begin{array}{l}\text { Izvod de documenturile, aparținînd Tarsiței } \\
\text { Druganova }\end{array}$ & " \\
\hline 682 & 1819 & iunie & 4 & $\begin{array}{l}\text { Învoiala între Ioan Gafenco și Ioan Dașcovici } \\
\text { pentru moșie }\end{array}$ & ” \\
\hline 683 & 1823 & ianuarie & 30 & $\begin{array}{l}\text { Chitanța lui Onofrei \& Popa pentru primirea } \\
\text { cîștiului moției Dărcăuți }\end{array}$ & ” \\
\hline 684 & 1823 & ianuarie & 13 & Izvod de cheltuelile făcute în pricina lui Ioan Buzuc & 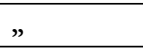 \\
\hline 685 & 1821 & iunie & 17 & Contract încheiat între Hrisostrat și Ion Buzuc & ” \\
\hline 686 & 1821 & - & - & Izvod de lucrul zilelor boierescului pe anul 1821 & ” \\
\hline 687 & 1821 & mai & 14 & $\begin{array}{l}\text { Scrisoarea lui < Gheorghe > Hrisostrat, < din } \\
\text { Chișinău }>\text {, către } \operatorname{Ioan}^{204} \text { în chestia unor moșii } 205\end{array}$ & " \\
\hline 688 & - & - & - & $\begin{array}{l}\text { Socoteala epitropului Gheorghe Meleli cu averea } \\
\text { răposatului Ion canțiler }\end{array}$ & " \\
\hline 689 & 1823 & martie & 9 & Învoiala între epitropii răposatului canțelerin & trad. \\
\hline 690 & 1825 & decembrie & 10 & $\begin{array}{l}\text { Mărturia lui Iordache Pavlov că el a scris un } \\
\text { contract al lui Filodor Casianov }\end{array}$ & românesc \\
\hline 691 & 1824 & aprilie & 23 & Contract încheiat între Beniș Nosovici și Vasilii & copie \\
\hline 692 & 1828 & iulie & 4 & Mărturia lui Nuhim dată lui Mihai Bădărău & românesc \\
\hline 693 & 1823 & martie & 2 & $\begin{array}{l}\text { Scrisoarea lui Vasilie Onuț către cuconul Mihalache } \\
\text { în pricina moșiei Bolotina }\end{array}$ & " \\
\hline 694 & 1827 & decembrie & 16 & $\begin{array}{l}\text { Copie după hotărîrea Judecătoriei ținutului Hotin } \\
\text { în pricina lui Ion „Carnilă” și Vasilie, Miron, Toma, } \\
\text { pentru moșia Bolotina }\end{array}$ & $"$ \\
\hline 695 & 1823 & august & 23 & $\begin{array}{l}\text { Povestca }^{207} \text { Isprăvniciei ținutului Eși către } \\
\text { Mihalache Bădărău }\end{array}$ & " \\
\hline 696 & 1828 & iulie & 7 & $\begin{array}{l}\text { Mărturia sătenilor din Bolotina pentru hotarul } \\
\text { acestui sat }\end{array}$ & " \\
\hline 697 & - & - & - & $\begin{array}{l}\text { Copia tălmăcită din evreiește a zapisului ce dă } \\
\text { Abram Mișcovici }\end{array}$ & $"$ \\
\hline 698 & - & - & - & Idem & ” \\
\hline 699 & 1827 & aprilie & 23 & $\begin{array}{l}\text { Izvod de cîtă datorie are să ia Sava posesorul moșiei } \\
<\text { Bădiceni }>208\end{array}$ & românesc \\
\hline 700 & 1827 & aprilie & 10 & Chitanța pentru 15 lei a lui Gheorghe Raneti & ” \\
\hline 701 & 1827 & aprilie & 23 & Chitanța pentru 578 lei a lui Ștefan Stirupovschi & 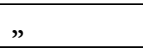 \\
\hline 702 & 1827 & august & 1 & $\begin{array}{l}\text { Chitanța primirii cîștiului de la sătenii din } \\
<\text { Bădiceni }>209\end{array}$ & ” \\
\hline 703 & 1827 & octombrie & 26 & $\begin{array}{l}\text { Izvod de banii ce este de luat de la sătenii moșiei } \\
<\text { Bădiceni }>\end{array}$ & " \\
\hline 704 & - & - & - & Mărturia în pricina „Zapanului” și a lui Ponici & $"$ \\
\hline 705 & $\frac{7258}{1750}$ & ianuarie & 23 & Învoiala răzeșilor pentru moșia Tomești ${ }^{210}$ & $"$ \\
\hline
\end{tabular}

\footnotetext{
${ }^{204}$ În text: „Ioan Buzuc”.

${ }^{205}$ Boga (1928b), p. 72, nr. LXXXIX.

${ }^{206}$ Boga (1928b), p. 91, nr. CXVII.

${ }^{207}$ Rusism: „citație”.

${ }^{208}$ În text: „Badigleni”.

${ }^{209}$ În text: „Radiceni, iar în rezumatul următor: „Rădiceni”.

${ }^{210}$ MEF, VIII, p. 217-218, nr. 176.
} 


\begin{tabular}{|c|c|c|c|c|c|}
\hline 706 & $\frac{7216}{1707}$ & octombrie & 28 & Cartea veliților boieri în pricina moșiei Tomești & $"$ \\
\hline 707 & - & - & - & Act razlit ${ }^{211}$ evreiesc & ” \\
\hline 708 & 1826 & august & 20 & $\begin{array}{l}\text { Declarațiile lui Pavel Caraș prin care declară că } \\
\text { banii ce are de primit de la Gangu i-a primit }\end{array}$ & rusesc \\
\hline 709 & 1827 & noiembrie & 15 & $\begin{array}{l}\text { Contract încheiat între rezeșii de Badiceni și Sava } \\
\text { Gangu }\end{array}$ & copie românească \\
\hline 710 & - & - & - & Act evreiesc & \\
\hline 711 & 1821 & februarie & 4 & $\begin{array}{l}\text { Răvaşul lui Iordache Manoli pentru primirea unui } \\
\text { arnăut }\end{array}$ & românesc \\
\hline 712 & 1821 & mai & 23 & $\begin{array}{l}\text { Hotărîrea Judecătoriei ținutului Eși în pricina } \\
\text { Varvarei „Haritul” }\end{array}$ & ” \\
\hline 713 & 1793 & august & 30 & $\begin{array}{l}\text { Copie după judecata vornicului Vasilie Mandu și } \\
\text { Aftenie Turuta }\end{array}$ & ” \\
\hline 714 & 1793 & august & 30 & $\begin{array}{l}\text { Copie de pe judecata lui Ștefan „Copel” și Jora } \\
\text { polcovnicul }\end{array}$ & ” \\
\hline 715 & 1815 & iulie & 13 & Mărturia unor răzeși de Dumbrăvița & ” \\
\hline 716 & 1824 & ianuarie & 25 & $\begin{array}{l}\text { Izvod de zestre dat de Dimitrache porucicu fiicei } \\
\text { sale }^{212}\end{array}$ & ” \\
\hline 717 & - & - & - & $\begin{array}{l}\text { Copia contractului încheiat de David Volcovici și } \\
\text { Ion Z. Saşbei }\end{array}$ & ” \\
\hline 718 & 1821 & martie & 13 & $\begin{array}{l}\text { Mărturia dată lui Dumitrache „Mintoci” pentru } \\
\text { moșia Slobozia }\end{array}$ & ” \\
\hline 719 & - & - & - & Mărturia lui Ivan Varnițchi pentru moșia Trifăuții & ” \\
\hline 720 & 1820 & august & 5 & $\begin{array}{l}\text { Mărturia dată de ierei Onofrei pentru moșia } \\
\text { Slobozia }\end{array}$ & " \\
\hline 721 & $\frac{7112}{1604}$ & aprilie & 20 & $\begin{array}{l}\text { Suret după cartea lui Eremia Movilă voievod pentru } \\
\text { satul Nemțeni, <din ținutul Soroca }>^{213}\end{array}$ & copie românească \\
\hline 722 & $\frac{7118}{1610}$ & iulie & 12 & $\begin{array}{l}\text { Suret după < uricul lui> Constantin Movilă voievod } \\
\text { pentru satul Nemțeni, < din ținutul Soroca, întărit } \\
\text { lui Coste Băcioc mare paharnic > } 214\end{array}$ & idem \\
\hline 723 & 1786 & iulie & 7 & $\begin{array}{l}\text { Mărturia pentru hotarul moșiei Nemțeni, <din } \\
\text { ținutul Soroca }>215\end{array}$ & românesc \\
\hline 724 & 1822 & ianuarie & 18 & Vechilime dată de Milo lui Iordache Zagura & " \\
\hline 725 & 1797 & octombrie & 26 & $\begin{array}{l}\text { Alegerea părților căpitanului Ioniță Mitică din } \\
\text { moșia Sfeteni }\end{array}$ & " \\
\hline 726 & 1822 & februarie & 17 & Jalba lui C. Ceapă în pricina moșiei „Hațașeni” & " \\
\hline 727 & 1797 & octombrie & 30 & $\begin{array}{l}\text { Hotarnica moșiei Valea lui Vlad <și a moșiei } \\
\text { Sfinteni, din ținutul Orhei }{ }^{216}\end{array}$ & românesc, copie \\
\hline 728 & 1801 & iulie & 20 & $\begin{array}{l}\text { Zapisul lui }<\text { Aftinie }{ }^{217} \text { Bunescu pentru moșia } \\
\text { Cucioaia, }<\text { din ținutul Orhei }>\end{array}$ & românesc \\
\hline 729 & 1822 & martie & 9 & $\begin{array}{l}\text { Raportul de la căpitanul de mazili din ocolul } \\
\text { Codrul }\end{array}$ & ” \\
\hline 730 & 1785 & septembrie & 20 & $\begin{array}{l}\text { Cartea lui Alexandru Mavrocordat voievod pentru } \\
\text { moșia Cornova }^{218}\end{array}$ & ” \\
\hline 731 & 1797 & octombrie & 26 & Hotarnica moșiei Cornova & ” \\
\hline 732 & 1801 & iunie & 15 & Zapisul Uscaților pentru moșia Cornova & " \\
\hline 733 & 1797 & octombrie & 26 & Referatul boierilor pentru hotarele moșiei Cornova & ” \\
\hline
\end{tabular}

\footnotetext{
${ }^{211}$ Rusism: „diferit”.

${ }^{212}$ Boga (1928a), p. 35-36, nr. XXIII.

${ }^{213}$ Boga (1929d), p. 3-4, nr. I (cu data de zi: „1”).

${ }^{214}$ Boga (1929d), p. 7-9, nr. IV; MEF, I, p. 246-249, nr. 105.

${ }^{215}$ Boga (1938a), p. 121-122, nr. XLIII; Doc. Ț. Mold., X, p. 226-227, nr. 178.

${ }^{216}$ Boga (1938a), p. 190-197, nr. LV.

217 În text: „Aftina”.

${ }^{218}$ Doc. T..Mold., X, p. 202-203, nr. 158.
} 


\begin{tabular}{|c|c|c|c|c|c|}
\hline 734 & 1815 & februarie & 7 & Zapisul lui Stati Frunză pentru moșia Hâncești & " \\
\hline 735 & 1816 & mai & 24 & $\begin{array}{l}\text { Porrunca Departamentului I către Isprăvnici } \\
\text { ținutului Eși }\end{array}$ & $"$ \\
\hline 736 & 1825 & martie & 15 & Zapisul sătenilor din Bănești pentru niște locuri & $"$ \\
\hline 736 & - & - & - & $\begin{array}{l}\text { Izvod de averea rămasă după moartea lui S. } \\
\text { Gheorghiu }\end{array}$ & $"$ \\
\hline 737 & 1824 & iulie & 10 & Diata lui Ion Popa ${ }^{219}$ & ” \\
\hline 738 & 1825 & mai & 7 & $\begin{array}{l}\text { Zapisul Balașei pentru vînzarea unui loc din } \\
\text { Vrănești, <din ținutul Iași> }\end{array}$ & $"$ \\
\hline 739 & 1820 & aprilie & 8 & $\begin{array}{l}\text { Mărturia locuitorilor din satul Mănzătești pentru o } \\
\text { cumpărătură a lui Nicoară }\end{array}$ & ” \\
\hline 740 & $\frac{7269}{1761}$ & august & 8 & $\begin{array}{l}\text { Cartea lui Grigore Ghica voievod pentru hotarul } \\
\text { satului Sarești }\end{array}$ & $"$ \\
\hline 741 & 1803 & martie & 1 & Spița neamului Nicoară & ” \\
\hline 742 & 1806 & martie & 5 & $\begin{array}{l}\text { Jalba lui Mihalache Coste către domn în pricina lui } \\
\text { cu I. Cantacuzino }\end{array}$ & $"$ \\
\hline 743 & 1805 & aprilie & 2 & $\begin{array}{l}\text { Scrisoare către Mihalache Coste în pricina unei } \\
\text { jalbe }\end{array}$ & " \\
\hline 744 & 1802 & august & 15 & $\begin{array}{l}\text { Scrisoare către vatavul Mihalache Coste pentru o } \\
\text { < răscoală ce au făcut orheienii împotriva domnului, } \\
\text { cu porunca: „caută, îți hoalbă ochii, și răvașu acesta } \\
\text { să-l arzi în foc” } 220\end{array}$ & ” \\
\hline 745 & 1813 & martie & 31 & Scrisoarea Marioarei în pricina moșiei Răcăciuni & grecesc \\
\hline 746 & 1806 & ianuarie & 16 & Scrisoarea către Coste vatavul pentru nişte scrisori & românesc \\
\hline 747 & 1815 & - & - & $\begin{array}{l}\text { Raportul Departamentului I al oblastiei Basarabia } \\
\text { pentru niște datorii ale lui Canta }\end{array}$ & $"$ \\
\hline 748 & 1814 & ianuarie & 21 & Scrisoarea Mariei către domn pentru niște datorii & grecesc \\
\hline 749 & 1802 & martie & 20 & Adeverința lui Cantacuzino dată lui Coste vatavul & românesc \\
\hline 750 & 1802 & martie & - & $\langle\text { Sama }\rangle^{221}$ vatavului Mihalache Coste & $"$ \\
\hline 751 & 1805 & martie & 16 & $\begin{array}{l}\text { Jalba vatavului Coste către domn contra lui I. } \\
\text { Cantacuzino }\end{array}$ & ” \\
\hline 752 & - & - & - & Izvodul actelor moșiei „Butești” & românesc cu $4 \ldots{ }^{222}$ \\
\hline 753 & 1839 & februarie & 29 & $\begin{array}{l}\text { Scrisoare către jupănul Avram pentru a obține un } \\
\text { împrumut }\end{array}$ & românesc \\
\hline 754 & 1835 & mai & 22 & $\begin{array}{l}\text { Răspunsul lui Alexandru Sturză în pricina averii } \\
\text { surorii sale, Ruxandra }\end{array}$ & $”$ \\
\hline 755 & 1812 & mai & 16 & $\begin{array}{l}\text { Jalba lui Ștefan Scorpan în pricina moșiei Butești, } \\
\text { <din ținutul Iași> }\end{array}$ & $"$ \\
\hline 756 & 1777 & aprilie & 30 & $\begin{array}{l}\text { Zapisul lui Feghi pentru 1/4 din moșia } \\
<\text { Lalova }>^{223},<\text { din ținutul Orhei }>\end{array}$ & $"$ \\
\hline 757 & 1766 & octombrie & 7 & $\begin{array}{l}\text { Copie după învoiala între Damaschin și Ifrim } \\
\text { Băciul }^{224}\end{array}$ & " \\
\hline 758 & 1859 & octombrie & 8 & $\begin{array}{l}\text { Contract de vînzare a moșiei Pogorăști, < din ținutul } \\
\text { Iași> }\end{array}$ & $"$ \\
\hline 759 & 1811 & noiembrie & 29 & Spița neamului Strămbu & ” \\
\hline 760 & 1803 & ianuarie & 18 & $\begin{array}{l}\text { Jalba lui Gh. }<\text { Ciuhoreanu }{ }^{225} \text { către domn în } \\
\text { pricina moșiei Toxobenii }\end{array}$ & $"$ \\
\hline
\end{tabular}

\footnotetext{
${ }^{221}$ În text: „suma”.

${ }^{222}$ Cuvînt tăiat la legat.

${ }^{223}$ În text: „Larova”.

${ }^{224}$ Doc. T,.Mold., IX, p. 193-195, nr. 167.

${ }^{225}$ În text: „Ciubur”.
}

${ }^{219}$ Boga (1929a), p. 60-61, nr. XXXVII (cu data de zi: „10”).

${ }^{220}$ În text: ,jalbă ce vor să dea Orheiului”. Boga (1928b), p. 15-16, nr. VIII (pasajul dintre ghilimele a fost pus de editor drept motto la acest grupaj de scrisori); Doc. Ț. Mold., XII, p. 116-117, nr. 92 (text după original, fără menționarea ediției lui Boga). 


\begin{tabular}{|c|c|c|c|c|c|}
\hline 761 & 1812 & iunie & 24 & Socoteala venitului moșie Zamcii ${ }^{226}$ & " \\
\hline 762 & 1803 & iunie & & $\begin{array}{l}\text { Porunca Isprăvniciei ținutului Eșii către Leonard } \\
\text { pentru moșia Măgurelele }\end{array}$ & " \\
\hline 763 & 1803 & mai & 29 & $\begin{array}{l}\text { Cartea lui Alexandru Moruzi voievod în pricina } \\
\text { moșiei Măgurelele }\end{array}$ & $"$ \\
\hline 764 & 1803 & maiu & 28 & Jalba lui Ciuhuran către domn & ” \\
\hline 765 & 1811 & mai & 20 & $\begin{array}{l}\text { Jalba lui „Gameț” către Cnejia Moldovei în pricina } \\
\text { moșiei „Hârmoșeni” } 228\end{array}$ & $"$ \\
\hline 766 & 1768 & octombrie & 19 & $\begin{array}{l}\text { Cartea lui Grigorie Calimah voievod în pricina } \\
\text { moșiei Sipoteni }\end{array}$ & copie românească \\
\hline 767 & 1826 & decembrie & 6 & Hotărîrea epitropiei casei Iamandi & românesc \\
\hline 768 & 1826 & noiembrie & 6 & $\begin{array}{l}\text { Adeverința dată lui „Cherchina”, <care > a dat jalba } \\
\text { la Judecătorie pentru țigani }\end{array}$ & românesc, copie \\
\hline 769 & 1818 & iulie & 6 & Izvod de partea pitarului $<$ Ciohoranu $>^{229}$ & românesc \\
\hline 770 & 1826 & mai & 16 & Mărturia lui Ioniță Șadbei dată negustorului Bolfos & ” \\
\hline 771 & - & - & - & Spița neamului Morozeanu & " \\
\hline 772 & - & - & - & Spița neamului „Stabui Gajiu” & " \\
\hline 773 & 1808 & ianuarie & 25 & $\begin{array}{l}\text { Raportul lui <Dimitrie > Jărdan < vornic > privitor la } \\
\text { hotarele moșiei Hârcești <şi ale moşiilor Târnușa și } \\
\text { Dumbrăvița, din ținutul Iașilor > } 230\end{array}$ & $"$ \\
\hline 774 & 1808 & ianuarie & 25 & Spița neamului „Hărcea” vel vornic & " \\
\hline 775 & 1818 & septembrie & 20 & Izvod de hîrtiile date la Judecătorie $<$ de $>$ Ochincă & ” \\
\hline 776 & 1826 & august & 8 & $\begin{array}{l}\text { Act de tovărășie între V. Constant și Averchie } \\
\text { Constantini }\end{array}$ & grecesc \\
\hline 777 & - & - & - & Izvod de hîrtiile date la Judecătorie $<$ de $>$ Ochincă & românesc \\
\hline 778 & 1827 & - & - & $\begin{array}{l}\text { Izvod de despăgubirile ce s-au pricinuit pe moșia } \\
\text { Vădeni de Constantin Sturza }\end{array}$ & " \\
\hline 779 & 1826 & septembrie & 29 & $\begin{array}{l}\text { Povestca Judecătoriei ținutului Eși către Petru } \\
\text { Ochincă în pricina moșiei Vădeni }\end{array}$ & ” \\
\hline 780 & 1825 & noiembrie & 26 & $\begin{array}{l}\text { Povestca Isprăvniciei ținutului Eși către vornicul } \\
\text { Costache Sturza în pricina moșiei Vădeni }\end{array}$ & ” \\
\hline 781 & 1823 & iulie & 18 & $\begin{array}{l}\text { Mărturia dată de locuitorii satului Vădeni la această } \\
\text { moșie }\end{array}$ & " \\
\hline 782 & 1823 & martie & 5 & $\begin{array}{l}\text { Contract încheiat între C. Sturza și P. Ochincă } \\
\text { pentru moșia Vădeni }\end{array}$ & " \\
\hline 783 & 1823 & aprilie & 29 & Contract încheiat între Istrati și sătenii din Recea & ” \\
\hline 784 & 1824 & noiembrie & 4 & $\begin{array}{l}\text { Mărturia dată de Bogdan lui Alexandru Vasiliu } \\
\text { pentru moșia <Iugani> } 231\end{array}$ & $"$ \\
\hline 785 & 1825 & februarie & 6 & $\begin{array}{l}\text { Adeverința căpitanului de mazili din ocolul Turia } \\
\text { pentru pădurea de pe moșia <Iugani> }\end{array}$ & ” \\
\hline 786 & 1821 & mai & 19 & $\begin{array}{l}\text { Chitanța protoiereului D. Crijanovschi pentru } \\
\text { banii împrumutați de la Stărce }\end{array}$ & $"$ \\
\hline 787 & 1824 & martie & 11 & $\begin{array}{l}\text { Protestul lui Stărce contra protoiereului } \\
\text { Crijanovschi în pricina banilor ce-i datorează }\end{array}$ & ” \\
\hline 788 & 1803 & iulie & 1 & $\begin{array}{l}\text { Mărturia hotarnică pentru satul Sânești <și pentru } \\
\text { satul Mânzătești, din ținutul Iași > } 232\end{array}$ & românesc, copie \\
\hline 789 & 1822 & februarie & 26 & Jalba dela răzeșii Tațulești din moşia Sinești & românesc \\
\hline
\end{tabular}

\footnotetext{
${ }^{226}$ Probabil, „Zamcioji” (ținutul Orhei).

${ }^{227}$ Doc. T,. Mold., XII, p. 171, nr. 158.

${ }^{228}$ Poate „Hăsnășeni”.

${ }^{229}$ În text: „Ciorocanu”.

${ }^{230}$ Boga (1938a), p. 261-263, nr. LXX. Mărturia boierilor Divanului, prin care a fost autentificată această hotarnică, a fost dată la 20 iulie 1808 (Doc. T,.Mold. (2016), p. 338-342, nr. 364).

${ }^{231}$ În text: „Urgani”, iar în rezumatul următor: „Iungani”.

${ }^{232}$ Boga (1938a), p. 238-241, nr. LXIV.
} 


\begin{tabular}{|c|c|c|c|c|c|}
\hline 790 & 1821 & martie & 14 & $\begin{array}{l}\text { Copie după zapisul de învoială încheiat între răzeșii } \\
\text { moșiei Sinești }\end{array}$ & ” \\
\hline 791 & 1822 & martie & 14 & $\begin{array}{l}\text { Raport de la căpitanul de mazili din ocolul Codru } \\
\text { în pricina moșiei Sinești }\end{array}$ & " \\
\hline 792 & 1822 & mai & 1 & $\begin{array}{l}\text { Raportul capitanului de mazili din ocolul Codru în } \\
\text { pricina moșiei Sinești }\end{array}$ & ” \\
\hline 793 & 1824 & aprilie & 23 & $\begin{array}{l}\text { Contract încheiat între „Cacianu” și Beinuș } \\
\text { Nusamovici pentru arendarea satului Copaceanca, } \\
\text { <din ținutul Iași> }\end{array}$ & ” \\
\hline 794 & - & - & - & $\begin{array}{l}\text { Ravaş, cu iscălitura indescifrabilă, în chestiunea } \\
\text { unor vaci }\end{array}$ & ” \\
\hline 795 & 1823 & noiembrie & 25 & $\begin{array}{l}\text { Notă de pretențiile ce le are Ciuhureanu de la } \\
\langle\text { Banar }>233\end{array}$ & ” \\
\hline 796 & 1818 & martie & 24 & $\begin{array}{l}\text { Răvaş către „cumnatul Gheorghe”, prin care cere } \\
\text { niște bani }\end{array}$ & $"$ \\
\hline 797 & 1823 & noiembrie & 26 & $\begin{array}{l}\text { Izvod de zestre ce s-au dat surorii lui Ciuhureanu, } \\
\text { ce-au fost soția lui Banar }\end{array}$ & ” \\
\hline 798 & - & - & - & $\begin{array}{l}\text { Răvaş, cu iscălitura indescifrabilă, prin care cere } \\
\text { niște bani }\end{array}$ & ” \\
\hline 799 & 1811 & martie & 22 & $\begin{array}{l}\text { Scrisoarea lui Iordache serdar către sluger în chestia } \\
\text { unor bani }\end{array}$ & ” \\
\hline 800 & - & iunie & 10 & Scrisoarea lui Iordache sluger în pricina unor bani & ” \\
\hline 801 & - & - & - & $\begin{array}{l}\text { Răvaş către „cumnatul Gheorghe” în chestia a } 800 \\
\text { ocă pește }\end{array}$ & $"$ \\
\hline 802 & 1815 & ianuarie & 5 & $\begin{array}{l}\text { Chitanța slugerului Gheorghe pentru } 1.806 \text { lei } \\
\text { primiți de la răzeșii din <Dumbrăvița }>234\end{array}$ & ” \\
\hline 803 & 1824 & decembrie & 2 & $\begin{array}{l}\text { Izvod de hîrtiile înfăţişate de Beldiman privitoare la } \\
\text { moșia Hăsnășeni }\end{array}$ & ” \\
\hline 804 & 1824 & februarie & 5 & $\begin{array}{l}\text { Adeverința de ridicare a unui document de la } \\
\text { Judecătorie }\end{array}$ & ” \\
\hline 805 & 1819 & iunie & 25 & $\begin{array}{l}\text { Chitanța de lei } 1.684 \text { dată de Anastasie Hagi Stoian } \\
\text { lui Costachi Leonard }\end{array}$ & $"$ \\
\hline 806 & 1810 & iulie & 16 & $\begin{array}{l}\text { Cartea Divanului Cneziei Moldovei în pricina lui } \\
\text { Gheorghe Cerchez și <a lui> Condurachi Petrica }\end{array}$ & ” \\
\hline 807 & 1820 & ianuarie & 12 & $\begin{array}{l}\text { Învoiala între Toader Hajdău și Ion Cazimir în } \\
\text { pricinile ce are Cazimir }\end{array}$ & ” \\
\hline 808 & 1820 & aprilie & 28 & $\begin{array}{l}\text { Adeverința lui Toader Hajdău pentru moșia } \\
\text { Hrimăncăuții }\end{array}$ & ” \\
\hline 809 & 1829 & iulie & & Planul moșiei Dercăuții & rusesc \\
\hline 810 & 1822 & februarie & 23 & $\begin{array}{l}\text { Scrisoarea lui Crupenschi dată fem<eii lui> Petrachi } \\
\text { „Holubosia” pentru moșia Hrițanii }\end{array}$ & românesc \\
\hline 811 & 1812 & februarie & 3 & $\begin{array}{l}\text { Cartea Divanului Cnejiei Moldovei in pricina lui } \\
\text { Gheorghe Ciuhureanu }\end{array}$ & $"$ \\
\hline 812 & 1825 & aprilie & 26 & Veniturile moșiei Hrițanii & grecesc \\
\hline 813 & 1824 & - & - & Diverse chitanțe semnate de Cantacuzino & $\begin{array}{l}<\text { nu se precizează limba } \\
\text { in care au fost scrise> }\end{array}$ \\
\hline 814 & 1804 & iunie & 15 & $\begin{array}{l}\text { Cartea lui Alexandru Moruzi voievod dată în } \\
\text { pricina preotului Iordache pentru moșia } \\
<\text { Cotiugeni }>235\end{array}$ & românesc \\
\hline 815 & 1830 & mai & 5 & Foaia de zestre a Mariei, fica lui „Marevsca” & ” \\
\hline 816 & 1820 & aprilie & 20 & $\begin{array}{l}\text { Mărturia lui Andrei Buşilă dată fraţilor Dabijești de } \\
\text { curgerea neamului lor }\end{array}$ & ” \\
\hline
\end{tabular}

\footnotetext{
${ }^{233}$ În text: „Baner”.

${ }^{234}$ În text: „D. Dîmbovița”.

${ }^{235}$ În text: „Costugeni”. Doc. T⿱⺌. Mold., XII, p. 251-254, nr. 259.
} 


\begin{tabular}{|c|c|c|c|c|c|}
\hline 817 & $\frac{7155}{1646}$ & septembrie & 11 & $\begin{array}{l}\text { Cartea lui Andreaș șoltuzul, cu cei } 12 \text { pîrgari din } \\
\text { Bârlad, pentru o vînzare făcută de Arsenie } \\
\text { Tudorache }\end{array}$ & $"$ \\
\hline 818 & 1824 & mai & 28 & Spița neamului Dabija & ” \\
\hline 819 & 1755 & decembrie & 18 & $\begin{array}{l}\text { Mărturia lui Vasilie Covrig pentru neamul } \\
\text { Dabijeștilor }\end{array}$ & " \\
\hline 820 & $\frac{7203}{1694}$ & decembrie & 18 & $\begin{array}{l}\text { Mărturia lui Vasilie Covrig pentru neamul } \\
\text { Dabijeștilor }\end{array}$ & 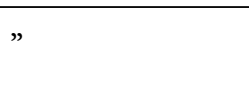 \\
\hline 821 & $\frac{7157}{1649}$ & ianuarie & 22 & $\begin{array}{l}\text { Cartea lui Vasilie voievod, dată către starostele } \\
\text { ținutului }<\text { Putna }>{ }^{237} \text { pentru niște vaduri de moară } \\
\text { pe Putna }\end{array}$ & $”$ \\
\hline 822 & $\frac{7163}{1655}$ & iulie & 23 & $\begin{array}{l}\text { Zapisul lui Porumb pentru vînzarea unor locuri de } \\
\text { la Rașcov }\end{array}$ & " \\
\hline 823 & $\frac{7155}{1647}$ & iunie & 4 & $\begin{array}{l}\text { Cartea lui Vasilie voievod, dată lui Neculai } \\
\text { neguțătorul din Bârlad, pentru niște vii din } \\
\text { Nicorești }\end{array}$ & $"$ \\
\hline 824 & $\frac{7155}{1647}$ & februarie & 20 & $\begin{array}{l}\text { Cartea lui Ivașco șoltuzul, cu cei } 12 \text { pîrgari din } \\
\text { Bârlad, pentru vînzarea unui loc de vie }\end{array}$ & $”$ \\
\hline 825 & 1788 & noiembrie & 13 & $\begin{array}{l}\text { Cartea boierilor Divanului Moldovei pentru } \\
\text { hotarele moșiei Florești }\end{array}$ & 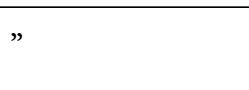 \\
\hline 826 & $\frac{7154}{1646}$ & ianuarie & 17 & $\begin{array}{l}\text { Cartea lui Vasilie voievod pentru un loc al lui } \\
\text { „Naiul” neguțător din Bârlad }\end{array}$ & " \\
\hline 827 & $\frac{7149}{1640}$ & octombrie & 8 & Cartea lui Vasilie voievod, idem & $"$ \\
\hline 828 & 1814 & septembrie & 4 & $\begin{array}{l}\text { Zapisul le schimb între Sandul Feodosiu şi Toader } \\
\text { Bodrug }\end{array}$ & $”$ \\
\hline 829 & 1798 & noiembrie & 9 & $\begin{array}{l}\text { Mărturia răzeșilor pentru hotarele moșiei } \\
\text { Flămânzeni, <din ținutul Iași }>238\end{array}$ & $”$ \\
\hline 830 & - & - & - & Planul moșiei „Petroșani”239 și Camenca & rusesc, cu trad. \\
\hline 831 & 1812 & august & 3 & $\begin{array}{l}\text { Porunca Isprăvniciei către frații Velișcu în pricina } \\
\text { moșiei Butești }\end{array}$ & $\begin{array}{l}\text { românesc, cu trad. } \\
<\text { rusească }>\end{array}$ \\
\hline 832 & 1832 & februarie & 20 & $\begin{array}{l}\text { Copia cărții lui Veaniamin mitropolitul Moldovei } \\
\text { în pricina divorțului lui P. Catargiu }\end{array}$ & 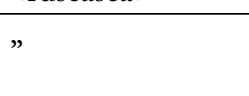 \\
\hline 833 & 1804 & decembrie & 24 & $\begin{array}{l}\text { Mărturia lui Onica „Stagu”, dată răzesilor din } \\
\text { Coșmirca, pentru venitul moșiei }\end{array}$ & ” \\
\hline 834 & 1797 & septembrie & 15 & $\begin{array}{l}\text { Zapisul de schimb între Varvara Vartic și Alexandru } \\
\text { „Zavenlin” biv vel portar }\end{array}$ & $”$ \\
\hline 835 & 1798 & iunie & 1 & $\begin{array}{l}\text { Mărturia dată pentru niște scrisori scoase în copie } \\
\text { ce se află la Ștefan Gorgos }\end{array}$ & $”$ \\
\hline 836 & 1835 & mai & 19 & $\begin{array}{l}\text { Mărturia dată răzeșilor din Coșmirca pentru } 25 \\
\text { stînjeni pămînt }\end{array}$ & ” \\
\hline 837 & 1799 & martie & 25 & $\begin{array}{l}\text { Chitanța de lei } 239 \text { dați la cumpărarea moșiei } \\
\text { Coșmirca }\end{array}$ & ” \\
\hline 838 & 1826 & martie & 18 & $\begin{array}{l}\text { Zapisul lui Alistar, cu frații săi, pentru vînzarea } \\
\text { unor părți din Coșmirca }\end{array}$ & $"$ \\
\hline 839 & 1797 & septembrie & 18 & Zapisul de vînzare al răzeșilor din Coșmirca & ” \\
\hline 840 & 1800 & noiembrie & 13 & Mărturia hotarnică a moșiei Coșmirca & ” \\
\hline 841 & 1806 & - & - & Spița răzeșilor moșiei Coșmirca & ” \\
\hline
\end{tabular}

\footnotetext{
${ }^{236}$ Dacă Vasilie Covrig este una și aceeași persoană, atunci unul dintre acte, avînd în vedere diferența mare dintre ani, are data greșită.

${ }^{237}$ În text: „Piatuci”.

${ }^{238}$ Boga (1938a), p. 198-200, nr. LVI.

${ }^{239}$ Probabil, „Petricani”.
} 


\begin{tabular}{|c|c|c|c|c|c|}
\hline 842 & 1816 & aprilie & 17 & $\begin{array}{l}\text { Scrisoarea <lui Dimitrachi> către archivistul }{ }^{240} \\
\text { condicar Ghiorghi, în privința unei învoieli cu } \\
\text { Arghir Cuza }\end{array}$ & românesc \\
\hline 843 & 1815 & august & 1 & Zapisul lui Arghir Cuza cu privire la satul Costești & ” \\
\hline 844 & 1815 & octombrie & 11 & Zapisul lui Dimitrie Ilie cu privire la satul Costești & ” \\
\hline 845 & 1817 & decembrie & 6 & $\begin{array}{l}\text { Copie după cartea lui Alexandru Calimah voievod } \\
\text { în pricina diacului Chirica }\end{array}$ & $"$ \\
\hline 846 & 1817 & aprilie & 12 & $\begin{array}{l}\text { Cartea lui Alexandru Calimah voievod în pricina } \\
\text { lui Arghir Cuza pentru moșia Costești }\end{array}$ & $"$ \\
\hline 847 & 1817 & martie & 19 & $\begin{array}{l}\text { Jalba către Divan a răzeșilor din neamul Tiron } \\
\text { pentru o parte din Cruhlic }\end{array}$ & $"$ \\
\hline 848 & $\frac{7095}{1597}$ & - & - & $\begin{array}{l}\text { Cartea lui Ștefan voievod, dată lui Petru Cărăbăț, } \\
\text { pentru satul Drăgușeni2 }{ }^{233}\end{array}$ & slovenesc \\
\hline 849 & $\frac{7098}{1590}$ & iulie & 1 & $\begin{array}{l}\text { Cartea lui Petru voievod dată lui Nicoară pentru } \\
\text { moșia (șters în original) }\end{array}$ & " \\
\hline 850 & $\frac{7105}{1597}$ & mai & 15 & $\begin{array}{l}\text { Zapisul lui Plopușor Eremia vătav pentru satul } \\
\text { Lihoconești, <din ținutul Hotin }{ }^{245}\end{array}$ & $"$ \\
\hline 851 & $\frac{7180}{1672}$ & iulie & 22 & $\begin{array}{l}\text { Zapisul lui Iancul Costin vel armaş prin care îssi } \\
\text { împarte averea }\end{array}$ & copie \\
\hline 852 & 1819 & aprilie & 22 & $\begin{array}{l}\text { Cartea lui Alexandru Calimah voievod în pricina } \\
\text { lui Arghir Cuza cu Dimitrie Eni }\end{array}$ & românesc \\
\hline 853 & 1817 & aprilie & 28 & $\begin{array}{l}\text { Cartea lui Alexandru Calimah voievod în pricina } \\
\text { lui Arghir Cuza cu Dimitrie Eni }\end{array}$ & " \\
\hline 854 & 1818 & februarie & 6 & $\begin{array}{l}\text { Copie după cartea de judecată domnească în pricina } \\
\text { lui Arghir Cuza cu Dumitru Eni }\end{array}$ & $"$ \\
\hline 855 & 1820 & august & 18 & Vechilimea dată de D. Iane fratelui său, Mihail Iane & ” \\
\hline 856 & 1814 & ianuarie & 17 & $\begin{array}{l}\text { Cartea comitetului, dată lui Soroceanu, pentru } \\
\text { moșiile socrului său, Davidel }\end{array}$ & ” \\
\hline 857 & 1816 & iulie & 6 & Actul de învoială între Teodor Hajdău și Mirjinschi & ” \\
\hline 858 & 1810 & mai & 11 & $\begin{array}{l}\text { Copie după cartea Divanului Moldovei, dată lui Ion } \\
\text { Bran, pentru moșia Bășcani, <din ținutul Hotin> }\end{array}$ & ” \\
\hline 859 & 1815 & ianuarie & 31 & $\begin{array}{l}\text { Răvaș de la Logofeția cea Mare în pricina lui } \\
\text { Nicolae Cărăman }\end{array}$ & $"$ \\
\hline 860 & 1812 & septembrie & 6 & $\begin{array}{l}\text { Referatul Divanului Cneziei Moldovei către } \\
\text { Crasno Milașevici pentru moșia Citnicăuți }\end{array}$ & ” \\
\hline 861 & - & - & - & $\begin{array}{l}\text { Zapisul Bilei, femeia lui Ionașcu, pentru moșia } \\
\text { Citnicăuți }\end{array}$ & românesc de prin 1700 \\
\hline 862 & $\frac{7117}{1609}$ & - & 15 & $\begin{array}{l}\text { Zapisul lui Mătieș Pahulcea pentru moșia } \\
\text { „Cnaşnalucea” } 247\end{array}$ & slovenesc \\
\hline 863 & 1813 & martie & 8 & $\begin{array}{l}\text { Hotărîrea Departamentului I al Basarabiei în } \\
\text { pricina lui Iordache Milo pentru moșia Citnicăuți }\end{array}$ & românesc \\
\hline 864 & - & - & - & $\begin{array}{l}\text { Zapisul Catrinei, fata Tudoriei, pentru o parte din } \\
\text { Citnicăuți }\end{array}$ & $"$ \\
\hline 865 & $\frac{7114}{1606}$ & mai & 15 & $\begin{array}{l}\text { Cartea lui Gheorghe pîrcălab de Hotin, dată lui } \\
\text { Vasile Buceațchi }\end{array}$ & $\begin{array}{l}\text { slovenesc, cu trad. } \\
\text { românească }\end{array}$ \\
\hline
\end{tabular}

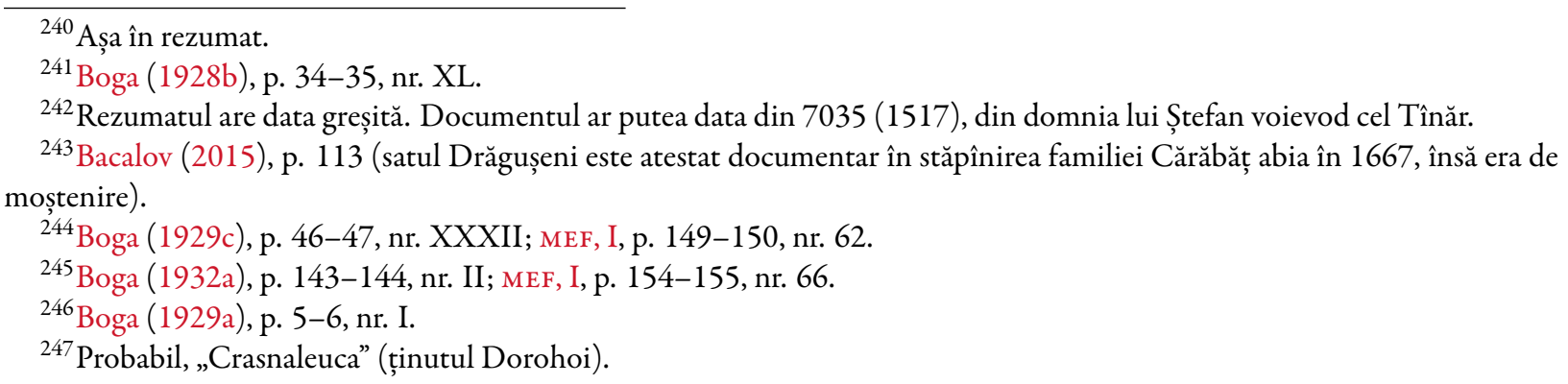




\begin{tabular}{|c|c|c|c|c|c|}
\hline 866 & $\begin{array}{l}<1820> \\
248\end{array}$ & martie & 18 & $\begin{array}{l}\text { Jalba lui Ioniță Moșanu vornic către domn contra } \\
\text { lui I. Ciurea }\end{array}$ & românesc \\
\hline 867 & $\frac{7143}{1635}$ & august & 14 & $\begin{array}{l}\text { Suret după ipisocul lui Vasile voievod prin care } \\
\text { întărește o vînzare a lui Buceațchi, < din satul } \\
\text { Cetnicăuți, ținutul Hotin > } 249\end{array}$ & " \\
\hline 868 & 1824 & ianuarie & 8 & $\begin{array}{l}\text { Mărturia răzeșilor din moșia Cerlina Mare cu } \\
\text { privire la darea ei în posesie }\end{array}$ & " \\
\hline 869 & 1811 & februarie & 11 & Mărturia cu privire la neamul lui Dabija și Davidel & ” \\
\hline 870 & 1812 & martie & 8 & $\begin{array}{l}\text { Copie după zapisul lui Cozmiță pentru o vînzare } \\
\text { făcută lui Davidel }\end{array}$ & $"$ \\
\hline 871 & 1826 & iulie & 5 & $\begin{array}{l}\text { Adeverința Sevastiei Chiruș cu privire la moșiile din } \\
\text { Hotin ale lui I. Ciure }\end{array}$ & " \\
\hline 872 & - & - & - & Spița neamului Soroceanu & ” \\
\hline 873 & 1806 & noiembrie & 20 & $\begin{array}{l}\text { Zapisul lui Mehmed prin care vinde un loc la } \\
\text { Colincăuți }\end{array}$ & românesc \\
\hline 874 & 1806 & noiembrie & 20 & Zapisul unui turc prin care vinde 920 stoguri fîn & copie românească \\
\hline 875 & 1822 & martie & 26 & $\begin{array}{l}\text { Scrisoarea de vechilime dată de Taușița Drubacova } \\
\text { lui Mârzac }\end{array}$ & românesc \\
\hline 876 & 1822 & aprilie & 21 & $\begin{array}{l}\text { Adeverința lui Vasile Stroescu pentru satul } \\
\text { Trinca } \\
250\end{array}$ & ” \\
\hline 877 & $\frac{7277}{1769}$ & iunie & 30 & $\begin{array}{l}\text { Cartea lui Grigore Calimah voievod către } \\
\text { Gheorghe Stroescu staroste de Cernăuți pentru } \\
\text { satul Vlădeni }\end{array}$ & copie românească \\
\hline 878 & 1828 & mai & 15 & Vechilime dată de Volcinschi lui Vasilie Grigore & românesc \\
\hline 879 & - & - & - & Împărțirea moșiilor lui Savin Ciomârtan & " \\
\hline 880 & 1767 & februarie & 13 & Mărturia privitoare la familia Grigorie & $"$ \\
\hline 881 & 1781 & - & - & $\begin{array}{l}\text { Cartea de judecaă a Divanului Cnejiei Moldovei în } \\
\text { pricina fraților Buțco }\end{array}$ & românesc, copie \\
\hline 882 & 1800 & ianuarie & 30 & $\begin{array}{l}\text { Zapisul lui Ion Mohorătu pentru satul } \\
\text { „Străneștii”251 }\end{array}$ & ” \\
\hline 883 & 1802 & mai & 1 & $\begin{array}{l}\text { Zapisul lui Ștefan <Dohatcul }{ }^{252} \text { pentru o parte } \\
\text { din Vlădeni }{ }^{253}\end{array}$ & " \\
\hline 884 & - & - & - & $\begin{array}{l}\text { Impărțeala moșiilor între }<\text { membrii }>\text { neamului } \\
\text { Volcinschi }\end{array}$ & " \\
\hline 885 & 1806 & iunie & 12 & $\begin{array}{l}\text { Jalba lui Ionița Ciomârtan către domn pentru satul } \\
\text { Vlădeni }\end{array}$ & românesc \\
\hline 886 & 1823 & februarie & 11 & $\begin{array}{l}\text { Povestca Judecătoriei oblastiei Basarabia către Ioniț̂i } \\
\text { Grigorie }\end{array}$ & " \\
\hline 887 & 1794 & decembrie & 2 & $\begin{array}{l}\text { Cartea lui Mihai Suțul voievod, dată lui Gherasim } \\
\text { Cantacuzino, în pricina ce o are cu Arghir Cuza }\end{array}$ & " \\
\hline 888 & 1822 & ianuarie & 20 & $\begin{array}{l}\text { Zapisul fraților Pasculești pentru cîteva locuri din } \\
\text { Sfișcăuți }\end{array}$ & copie românească \\
\hline 889 & 1828 & aprilie & 30 & $\begin{array}{l}\text { Scrisoarea mai multor răzeși către Grigorie } \\
\text { Dimitrievici prin care îl împuternicesc a-i } \\
\text { reprezenta la judecata ce-o au }\end{array}$ & ” \\
\hline 890 & 1828 & mai & 15 & Foaie de zestre a Aniței Vladimir & românesc \\
\hline 891 & 1824 & februarie & 26 & $\begin{array}{l}\text { Contract între răzeșii din Cureșnița și Polihroni } \\
\text { Malcoci }\end{array}$ & " \\
\hline
\end{tabular}

\footnotetext{
${ }^{248}$ În text, greșit: „1520”.

${ }^{249}$ Boga (1929d), p. 17-18, nr. XVI.

${ }^{250}$ Pentru Vasile Stroescu, vezi Bezviconi (1992), p. 201-202.

${ }^{251}$ Poate „Stroești” (ținutul Hotin).

${ }^{252}$ În text: „Dibățel”.

${ }^{253}$ Doc. T..Mold., XII, p. 107-108, nr. 82.

${ }^{254}$ Doc. T,. Mold., XI, p. 201-202, nr. 147.
} 


\begin{tabular}{|c|c|c|c|c|c|}
\hline 892 & 1824 & ianuarie & 20 & $\begin{array}{l}\text { Povestca Isprăvniciei ținutului Iaşi către Malcoci } \\
\text { pentru moșia Cureșnița }\end{array}$ & $"$ \\
\hline 893 & 1824 & februarie & 22 & Declarația lui Malcoci pentru moșia Cureșnița & ” \\
\hline 894 & 1824 & septembrie & 18 & $\begin{array}{l}\text { Povestca Isprăvniciei ținutului Iași către Polihroni } \\
\text { Malcoci }\end{array}$ & " \\
\hline 895 & 1822 & mai & 7 & Jalba răzeșilor din Cureșnița pentru această moșie & ” \\
\hline 896 & 1822 & mai & 7 & Contract între răzeșii moșiei Cureșnița și Malcoci & ” \\
\hline 897 & 1825 & iulie & 21 & $\begin{array}{l}\text { Porunca Isprăvniciei Soroca în pricina moșiei } \\
\text { Cureșnița }\end{array}$ & " \\
\hline 898 & 1826 & martie & 21 & $\begin{array}{l}\text { Mărturia răzeșilor din Cureșnița pentru venitul } \\
\text { moșiei }\end{array}$ & ” \\
\hline 899 & 1825 & septembrie & 1 & Povestca Isprăvniciei ținutului Iași către Malcoci & ” \\
\hline 900 & 1825 & iunie & 25 & Mărturia răzeșilor din Cureșnița & ” \\
\hline 901 & 1826 & ianuarie & 26 & Idem & ” \\
\hline 902 & 1825 & octombrie & 25 & Chitanța pentru 30 lei a lui Revencu & ” \\
\hline 903 & 1826 & ianuarie & 16 & Contract încheiat între Morar și Polihroni Malcoci & ” \\
\hline 904 & 1826 & martie & 26 & Izvod de dovezile pentru moșia Cureșnița & ” \\
\hline 905 & 1820 & octombrie & 28 & Contract pentru satul Cureșnița & ” \\
\hline 906 & 1825 & mai & 30 & $\begin{array}{l}\text { Cererea lui P. Constantinovici pentru moșia } \\
\text { Cazaneștii }\end{array}$ & ” \\
\hline 907 & 1822 & martie & 10 & Contract pentru moșia Cazaneștii & ” \\
\hline 908 & - & - & - & Izvodul acareturilor moșiei Cazaneștii & ” \\
\hline 909 & 1825 & septembrie & 13 & Jalba lui Constantinovici pentru moșia Cazaneștii & copie românească \\
\hline 910 & 1818 & - & - & Datornicii din satele „Bohieși” ${ }^{255}$, „Ciobanca” etc. & românesc \\
\hline 911 & 1821 & martie & 4 & $\begin{array}{l}\text { Adeverința lui Antohi Dolgheru pentru vînzarea } \\
\text { unui loc }\end{array}$ & $"$ \\
\hline 912 & 1821 & august & 10 & $\begin{array}{l}\text { Chitanța lui Vasilie Pogor pentru o afacere cu } \\
\text { Angello <la > Bălți }\end{array}$ & francez \\
\hline 913 & 1825 & iunie & 7 & Chitanțe semnate de Bantăș & 3 pi<ese $>$ \\
\hline 914 & 1824 & noiembrie & 26 & Contract pentru moșia $<$ Bădiceni ${ }^{256}$ & românesc \\
\hline 915 & 1823 & aprilie & 23 & Contract pentru moșia Costești & grecesc \\
\hline 916 & - & - & - & Notă de diverse cheltuieli & ” \\
\hline 917 & 1826 & ianuarie & 21 & $\begin{array}{l}\text { Izvod de dovezile aduse de Moșcovici în pricina cu } \\
\text { Bantăș }\end{array}$ & românesc \\
\hline 918 & 1824 & noiembrie & 26 & Act de tovărășie între Sava Popovici și Toader Petru & copie românească \\
\hline 919 & 1823 & noiembrie & 5 & $\begin{array}{l}\text { Contract de datoriile lui Strul, douăzeci și două } \\
\text { (22) file }\end{array}$ & în grecește și românește \\
\hline 920 & 1825 & mai & 30 & Mărturie dată lui Ursachi privitoare la zestre & românesc \\
\hline 921 & 1822 & septembrie & 6 & $\begin{array}{l}\text { Zapisul dat lui Ieni Diamandi pentru } 500<\text { lei }> \\
\text { împrumutați }\end{array}$ & ” \\
\hline 922 & 1823 & aprilie & 27 & $\begin{array}{l}\text { Contract încheiat între Vasilie Moșanu cu Ieni } \\
\text { Diamandi pentru vînzarea moșiei „Pupazanci” }\end{array}$ & ” \\
\hline 923 & 1819 & aprilie & 23 & Zapis de vînzare a moșiei Tărșeștii & 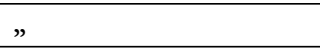 \\
\hline 924 & 1819 & octombrie & 5 & $\begin{array}{l}\text { Scrisoarea lui Panaioti Dioghenidi către Anghel } \\
\text { Vali }\end{array}$ & trad. în românește \\
\hline 925 & 1821 & august & 10 & Vechilimea dată de A.Vali lui V. Bogos & franțuzesc \\
\hline 926 & 1823 & martie & 22 & Învoiala între Dighionide și Vali & românesc \\
\hline 927 & 1821 & august & 10 & Exoflisis între A. Vali și V. Bogos & românesc, francez \\
\hline 928 & 1820 & iunie & 21 & Învoiala între Stavri și Enacache Crușevanu & românesc \\
\hline 929 & 1822 & iulie & 17 & Jalba Axeniei Rusul pentru zestrea sa & ” \\
\hline 930 & - & - & - & Izvod de banii ce-i datorează Condrateștii & ” \\
\hline 931 & 1821 & septembrie & 4 & $\begin{array}{l}\text { Izvod de locuitorii din Coșcodeni ce s-au împotrivit } \\
\text { a da dijma }\end{array}$ & ” \\
\hline 932 & 1819 & martie & 9 & Învoiala către răzeșii Bodrujești și Sandu Feodosiu & ” \\
\hline
\end{tabular}

${ }^{255}$ Poate „Boghiceni” (ținutul Orhei).

${ }^{256}$ În text: „Rădiceni”. 


\begin{tabular}{|c|c|c|c|c|c|}
\hline 933 & 1841 & noiembrie & 5 & Mărturie de botez a lui Ilie Patrașco & " \\
\hline 934 & 1819 & ianuarie & 21 & $\begin{array}{l}\text { Chitanța razeșilor Brănești pentru banii } \\
\text { împrumutați de la Cupcea }\end{array}$ & $"$ \\
\hline 935 & 1805 & iunie & 22 & $\begin{array}{l}\text { Adeverința locuitorilor din Chetrosu pentru } \\
\text { pagubele pricinuite imașului }\end{array}$ & ” \\
\hline 936 & 1811 & august & 2 & $\begin{array}{l}\text { Porunca Divanului către Isprăvnicia Sorocii pentru } \\
\text { pricina lui Hulubaș }\end{array}$ & ” \\
\hline 937 & 1806 & august & 10 & $\begin{array}{l}\text { Mărturia locuitorilor din Chetrosu pentru cîrciuma } \\
\text { lui Hulubaș }\end{array}$ & $"$ \\
\hline 938 & 1826 & august & 28 & $\begin{array}{l}\text { Arătarea lui Stavilă către Judecătoria Iași în pricina } \\
\text { moșiei Șurile, <din țintul Iași> }\end{array}$ & ” \\
\hline 939 & - & - & - & Învoiala între Ianchel Aizicovici și Herșcovici. & ” \\
\hline 940 & 1812 & noiembrie & 21 & Vechilime dată de Ioan Cazimir lui Toader Hajdău & ” \\
\hline 941 & 1824 & decembrie & 9 & Contract între Nedova și Leiba Herțan & ” \\
\hline 942 & 1812 & aprilie & 1 & $\begin{array}{l}\text { Copie după cartea Divanului Moldovei pentru } \\
\text { moșiile lui Costache Ghica din ținutul Hotin }\end{array}$ & ” \\
\hline 943 & 1811 & martie & & $\begin{array}{l}\text { Mărturia pentru moșiile Ciomortăneștilor din } \\
\text { ținutul Hotin }\end{array}$ & copie \\
\hline 944 & 1818 & martie & 15 & Porunca pîrcălabului Hotinului către L. Sârbu & ” \\
\hline 945 & 1827 & ianuarie & 31 & $\begin{array}{l}\text { Mărturia lui Vasilie Grigorie pentru pădurea } \\
<\text { Rujavinița }>257\end{array}$ & ” \\
\hline 946 & 1827 & ianuarie & 8 & $\begin{array}{l}\text { Mărturia lui Dimitrie Levin pentru pădurea } \\
\text { <Rujavinița > }\end{array}$ & ” \\
\hline 947 & 1827 & ianuarie & 6 & $\begin{array}{l}\text { Mărturia lui Costache Talpă și Iordache Oatul } \\
\text { pentru pădurea <Rujavinița }{ }_{258}\end{array}$ & ” \\
\hline 948 & 1822 & decembrie & 1 & $\begin{array}{l}\text { Contract de vînzare a jumătate din moșia Sângera } \\
\text { lui Ioan Tabără }\end{array}$ & ” \\
\hline 949 & 1824 & octombrie & 22 & Contract încheiat între M. Tăutul și Gh. Parasciuc & " \\
\hline 950 & 1786 & februarie & 19 & Izvod de stînjenii răzeșilor moșiei Coșmirca & ” \\
\hline 951 & 1819 & aprilie & 2 & $\begin{array}{l}\text { Scrisoarea lui <Tudorachi, fiul lui Mihalachi Grecul } \\
\text { căminar, nepotul lui> Calistru către <Chiriac și } \\
\text { Dumitru Calistru> }{ }^{259} \text {, în pricina spiței neamului } \\
<\text { Stroescu, de care se leagă și Vasile> Ursache }{ }^{260}\end{array}$ & " \\
\hline 952 & 1822 & noiembrie & 22 & Contract către Ion Tabără și Gh. Parasciuc & românesc \\
\hline 953 & - & - & - & Izvod de banii împrumutați de Iancu Abramovici & ” \\
\hline 954 & 1827 & martie & 27 & Izvod de locuitorii din satul Băneștii ce au datorii & 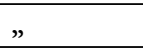 \\
\hline 955 & 1817 & martie & 26 & $\begin{array}{l}\text { Zapisul răzeșilor moșiei Vasieni pentru veniturile } \\
\text { moșiei }\end{array}$ & " \\
\hline 956 & 1810 & decembrie & 23 & $\begin{array}{l}\text { Cartea de la voievodul Moldovei în pricina lui } \\
\text { Nastase Andrei cu Toader Bodrug }\end{array}$ & $"$ \\
\hline 957 & 1820 & noiembrie & 20 & $\begin{array}{l}\text { Mărturia dată lui Calistru pentru moșia } \\
<\text { Zahoreni }{ }^{261}\end{array}$ & ” \\
\hline 958 & $\frac{7254}{1746}$ & mai & 29 & $\begin{array}{l}\text { Mărturia razeșilor Oprișeni, < din ținutul Soroca >, } \\
\text { pentru moșia lui <Bașotă }>262\end{array}$ & $"$ \\
\hline 959 & $\frac{7255}{1747}$ & februarie & 8 & Referatul boierilor pentru moșia Oprișeni & ” \\
\hline 960 & 1825 & octombrie & 28 & $\begin{array}{l}\text { Mărturia lui Vărnav cu privire la zestrea dată fiicei } \\
\text { sale de Ștefan „Străcescu” } 263\end{array}$ & ” \\
\hline
\end{tabular}

\footnotetext{
257 În text: „Rjdanița”.

${ }^{258}$ În text: „Rjavnițchi”.

${ }^{259}$ În text, greșit: ,către Ion”.

${ }^{260}$ Boga (1928b), p. 53-54, nr. LXVII.

${ }^{261}$ În text: „Zaboreni”.

${ }^{262}$ În text: „Bazată. MEF, VIII, p. 193-195, nr. 155.

${ }^{263}$ Greșit, pentru: „Isăcescu”.
} 


\begin{tabular}{|c|c|c|c|c|c|}
\hline 961 & 1818 & aprilie & 6 & $\begin{array}{l}\text { Hotărîrea Departamentului }<\mathrm{I} \text {-iu }>^{264} \text { în pricina lui } \\
\text { Vărnav }\end{array}$ & $"$ \\
\hline 962 & 1824 & ianuarie & 29 & Diata lui Ștefan Isăcescul ${ }^{265}$ & ” \\
\hline 963 & 1799 & mai & 20 & Izvod de zestre dată de Nic. Vărnav fiicei sale ${ }^{266}$ & ” \\
\hline 964 & 1824 & iulie & 8 & $\begin{array}{l}\text { Declarația lui Govdela cu privire la locuința lui } \\
\text { Alexandru Manu }\end{array}$ & " \\
\hline 965 & 1824 & ianuarie & 30 & $\begin{array}{l}\text { Izvod de zestre ce s-au dat Catincăi, fiica lui } \\
\text { Isăcescu } \\
267\end{array}$ & $"$ \\
\hline 966 & 1818 & iunie & 29 & $\begin{array}{l}\text { Izvod de zestre ce s-a dat Smarandei, fiicei lui } \\
\text { Isăcescu } \\
268\end{array}$ & " \\
\hline 967 & 1800 & iunie & 26 & $\begin{array}{l}\text { Cartea lui Constantin Ipsilanti voievod în pricina } \\
\text { lui Ioniță Sgardan } 269\end{array}$ & $"$ \\
\hline 968 & 1800 & iunie & 10 & $\begin{array}{l}\text { Mărturia hotarnică a moșiei <Băxanii, din ținutul } \\
\text { Soroca }>270\end{array}$ & " \\
\hline 969 & 1821 & martie & 18 & $\begin{array}{l}\text { Hotărîrea Judecătoriei < politicești }{ }^{271} \text { a }>\text { Basarabiei } \\
\text { pentru moșia Baxanii }\end{array}$ & copie românească \\
\hline 970 & 1818 & iunie & 30 & Învoiala între răzeșii moșii Baxani & românesc \\
\hline 971 & 1796 & iunie & 25 & $\begin{array}{l}\text { Cartea lui Alexandru Calimah voievod în pricina } \\
\text { lui Tomiță Roșca }\end{array}$ & ” \\
\hline 972 & 1797 & iulie & 21 & $\begin{array}{l}\text { Cartea lui Alexandru Mavrocordat voievod în } \\
\text { pricina lui Constantin Macovei }\end{array}$ & ” \\
\hline 973 & 1816 & iunie & 13 & $\begin{array}{l}\text { Porunca Departamentului 1-iu către Isprăvnicia de } \\
\text { Soroca în pricina lui Carp Opre }\end{array}$ & " \\
\hline 974 & 7138 & iunie & 12 & $\begin{array}{l}\text { Zapisul lui Gheorghe <Balș> pentru o parte din } \\
\text { moșia Bacșanii }\end{array}$ & copie românească \\
\hline 975 & 1850 & august & 10 & $\begin{array}{l}\text { Porunca Isprăvniciei Soroca în pricina lui Carp } \\
\text { Opre }\end{array}$ & românesc \\
\hline 976 & 1802 & mai & 13 & $\begin{array}{l}\text { Hotărîrea în pricina hotarelor moşiei „Varul } \\
\text { țărei” }\end{array}$ & " \\
\hline 977 & 1813 & iulie & 13 & Chitanța lui Nichita pentru 199 lei & ” \\
\hline 978 & 1824 & mai & 17 & Jalba răzeșilor moșiei Bolotina & 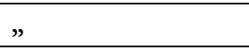 \\
\hline 979 & 1817 & mai & 7 & $\begin{array}{l}\text { Zapisul lui Vasilie Gale prin care vinde o parte din } \\
\text { Bolotina }\end{array}$ & $"$ \\
\hline 980 & 1823 & iunie & 12 & $\begin{array}{l}\text { Zapisul lui Grigoraș Onița prin care vinde o parte } \\
\text { din Bolotina }\end{array}$ & ” \\
\hline 981 & 1799 & noiembrie & 2 & $\begin{array}{l}\text { Hotărîrea Divanului Moldovei în pricina dintre S. } \\
\text { Feodosiu și C. Sturza }\end{array}$ & " \\
\hline 982 & 1793 & iunie & 2 & $\begin{array}{l}\text { Zapisul lui Lupul Parfenie prin care vinde o parte } \\
\text { din Biliceni }\end{array}$ & $"$ \\
\hline 983 & 1803 & iunie & 7 & $\begin{array}{l}\text { <Mărturie > hotarnică în pricina dintre răzeșii din } \\
\text { moșiile Brădiceni și Burdujăni, <din ținutul } \\
\text { Soroca }{ }^{273}\end{array}$ & $"$ \\
\hline 984 & $\frac{7284}{1776}$ & martie & 4 & $\begin{array}{l}\text { Zapisul lui Parfenie Ionică prin care îi vinde } \\
\text { <cuiva > partea lui de moșie }\end{array}$ & $"$ \\
\hline 985 & $\frac{7259}{1751}$ & octombrie & 17 & $\begin{array}{l}\text { Hotărîrea ispravnicilor de Soroca în pricina lui } \\
\text { Ioniță Spânu și Gh. Croitor }\end{array}$ & $"$ \\
\hline
\end{tabular}

\footnotetext{
${ }^{264}$ În text: „11-lea”.

${ }^{265}$ Boga (1929a), p. 59-60, nr. XXXVI.

${ }^{266} \mathrm{Boga}$ (1928a), p. $12-13$, nr. VI.

${ }^{267}$ Boga (1929a), p. 59-60, nr. XXXVI.

${ }^{268}$ Boga (1928a), p. 36-38, nr. XXIV.

${ }^{269}$ Doc. T,. Mold., XI, p. 339-340, nr. 275.

${ }^{270}$ În text: „Bătanii”. Boga (1938a), p. 202-207, nr. LVIII.

${ }^{271}$ În text: „poliția”.

${ }^{272} \mathrm{Greu}$ de spus ce se ascunde sub aceste cuvinte citite greșit.

${ }^{273}$ Boga (1938a), p. 221-223, nr. LXII.
} 


\begin{tabular}{|c|c|c|c|c|c|}
\hline 986 & 1793 & - & - & Spița răzeșilor de Brădiceni & $"$ \\
\hline 987 & 1826 & martie & 15 & $\begin{array}{l}\text { Copie după jurnalul Judecătoriei ținutului Iași în } \\
\text { pricina moșiei Brădiceni }\end{array}$ & " \\
\hline 988 & 1828 & aprilie & 25 & $\begin{array}{l}\text { Zapisul Mariei „Gagiumneaza” prin care vinde o } \\
\text { parte din moșia „Bujerenca” }\end{array}$ & ” \\
\hline 989 & $\frac{7278}{1770}$ & mai & 19 & $\begin{array}{l}\text { Zapisul lui Lupașcu prin care dă nepoatei sale, } \\
\text { Maria, o vie }\end{array}$ & $”$ \\
\hline 990 & 1795 & iunie & 16 & $\begin{array}{l}\text { Hotărîrea Isprăvniciei Soroca în pricina Mariei, } \\
\text { nepoata lui Lupaș }\end{array}$ & $"$ \\
\hline 991 & 1842 & octombrie & 7 & $\begin{array}{l}\text { Diploma dată de țarul Nicolae I lui Feodor } \\
\text { Polvolnițchi }\end{array}$ & rusesc \\
\hline 992 & 1859 & februarie & 24 & Dania Mariei Orăș lui Ștefan Virbențevici & românesc \\
\hline 993 & 1854 & februarie & 2 & Testamentul lui Panaite Corioti & ” \\
\hline 994 & 1866 & martie & 18 & $\begin{array}{l}\text { Actul răzeșilor moșiei Năpădeni cu privire la } \\
\text { venitul moșiei }\end{array}$ & $"$ \\
\hline 995 & 1891 & aprilie & 28 & $\begin{array}{l}\text { Zapisul răzeșilor moșiei Zadureni cu privire la } \\
\text { venitul moșiei }\end{array}$ & ” \\
\hline 996 & 1815 & noiembrie & 30 & Izvod de lucrurile ce se află pe moșia Bulboci & ” \\
\hline 997 & 1833 & aprilie & 10 & $\begin{array}{l}\text { Hotărîrea Departamentului I-iu în pricina dintre } \\
\text { Vasilie Costachi și Flondorești }\end{array}$ & $" ”$ \\
\hline 998 & 1830 & mai & 24 & Vechilime dată de Ion Balasan lui Ion Bogdanovici & 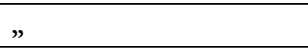 \\
\hline 999 & 1813 & februarie & 14 & Copie după izvodul de zestre dată Marii & ” \\
\hline 1000 & 1832 & aprilie & 20 & Scrisoarea Ecaterinei Ghica către Vasilie „Vancii” & ” \\
\hline 1001 & 1832 & aprilie & 8 & Pașaportul Casandrei Catargi & ” \\
\hline 1002 & 1840 & mai & 10 & $\begin{array}{l}\text { Adeverința lui Sandul Namesnicul }{ }^{274} \text { pentru cele } \\
\text { ce-i dă fiului său }\end{array}$ & $"$ \\
\hline 1003 & 1842 & decembrie & 20 & Mărturia lui Oțel pentru cele ce dă fiilor săi & românesc \\
\hline 1004 & 1823 & decembrie & 28 & Însemnare de prețul vitelor & ” \\
\hline 1005 & 1824 & februarie & 24 & Chitanța lui Ion Luca pentru 400 lei & ” \\
\hline 1006 & - & - & - & $\begin{array}{l}\text { Zapisul lui Gherman Berdiban prin care vinde } 1 \\
\langle\text { pogon vie }>276\end{array}$ & ” \\
\hline 1007 & 1854 & aprilie & 23 & $\begin{array}{l}\text { Contractul răzeșilor din Stoicani pentru pășunatul } \\
\text { vitelor }\end{array}$ & Lada nr. 2 \\
\hline 1008 & $\frac{7168}{1660}$ & aprilie & 20 & $\begin{array}{l}\text { Cartea lui Ștefan voievod prin care face danie } \\
\text { visternicului Duca satul <Dângeni, din ținutul Iași > }\end{array}$ & $\begin{array}{l}\text { slovenesc, pe } \\
\text { pergament, cu pecetea } \\
\text { de ceară }^{277}\end{array}$ \\
\hline 1009 & $\frac{7125}{1617}$ & martie & 12 & $\begin{array}{l}\text { Cartea lui Radul Mihnea voievod prin care face } \\
\text { danie lui Ștefan }<\text { Calinic }>\text { satul }<\text { Horbinești, pe } \\
\text { Cogâlnic, în ținutul Orhei }>278\end{array}$ & ” \\
\hline 1010 & $\frac{7056}{1548}$ & martie & 1 & $\begin{array}{l}\text { Cartea lui Iliaș voievod prin care face danie } \\
\text { jumătate < din > siliște, din Hrusca, pînă la Gura } \\
\text { Curvei }^{279}\end{array}$ & ” \\
\hline 1011 & $\frac{7036}{1528}$ & martie & 17 & $\begin{array}{l}\text { Cartea lui Petru voievod prin care face danie lui } \\
\text { Luca }<\text { Siurici }>{ }^{280} \text { satul Siuriceni }^{281}\end{array}$ & ” \\
\hline 1012 & $\frac{7113}{1605}$ & iunie & 6 & $\begin{array}{l}\text { Cartea lui Eremia Movilă voievod prin care face } \\
\text { danie lui Gavriil, Ioan și Moisei, nepoții lui „Tocușa” } \\
\text { pîrcălabul <de> Ciobărciu }{ }^{282} \text { o moșie lîngă Botna }\end{array}$ & $"$ \\
\hline
\end{tabular}

\footnotetext{
${ }^{274}$ În text: „cămenarul”.

${ }^{275}$ Boga (1929a), p. 74-75, nr. XLV.

${ }^{276}$ În text: „pogonerie”.

277 În text: „Dănceni”. Boga (1930c), p. 142-145, nr. IX; MEF, IV, p. 307-310; nr. 138.

${ }^{278}$ În text: „Calmâc”, „Albonești”. Boga (1929d), p. 9-10, nr. V; MEF, I, p. 313-317, nr. 139.

${ }^{279}$ Boga (1929c), p. 11-14, nr. VIII; MEF, II, p. 285-288, nr. 91.

${ }^{280}$ In text: ,Jurici”.

${ }^{281}$ Boga (1929c), p. 8-11, nr. VI; MEF, II, p. 258-261, nr. 82.

282 În text: „Ciobărceni”.
} 


\begin{tabular}{|c|c|c|c|c|c|}
\hline 1013 & $\frac{7081}{1573}$ & mai & 27 & $\begin{array}{l}\text { Cartea lui Ioan voievod prin care întărește } \\
\text { împărțeala între fiii lui Băloș paharnicul }{ }^{283}\end{array}$ & $\begin{array}{l}\text { slovenesc, pe hîrtie, cu o } \\
\text { trad. românească }\end{array}$ \\
\hline 1014 & $\frac{7081}{1573}$ & iunie & 30 & $\begin{array}{l}\text { Cartea lui Petru voievod prin care întărește vînzarea } \\
\text { satului Holohoreni de către Chirilă cu frații lui }{ }^{284}\end{array}$ & $\begin{array}{l}\text { slovenesc, pe o hîrtie, cu } \\
\text { traducere în românește }\end{array}$ \\
\hline 1015 & $\frac{7085}{1577}$ & iunie & 30 & $\begin{array}{l}\text { Cartea lui Petru voievod prin care întărește vînzarea } \\
\text { satului Holohoreni de către Morozeanul }{ }^{285}\end{array}$ & " \\
\hline 1016 & $\frac{7085}{1577}$ & iulie & 20 & $\begin{array}{l}\text { Cartea lui Petru voievod prin care întărește vînzarea } \\
\text { satului Holohoreni de către < Pătrașco și rudele } \\
\text { sale }>286\end{array}$ & " \\
\hline 1017 & $\frac{7086}{1577}$ & octombrie & 4 & $\begin{array}{l}\text { Cartea lui Petre voievod prin care întărește vînzarea } \\
\text { satului }<\text { Holohoreni }{ }^{287} \text { de către }<\text { Ion Șofranco } \\
\text { comișel }>288\end{array}$ & " \\
\hline 1018 & $\frac{7095}{1587}$ & martie & 20 & $\begin{array}{l}\text { Cartea lui Petre voievod prin care întărește vînzarea } \\
\text { satului Holohoreni făcută de Ioan <Șofranco〉 } \\
\text { comișel }^{289}\end{array}$ & $\begin{array}{l}\text { slovenesc, pe } \\
\text { pergament, rupt în } \\
\text { dreptul locului unde a } \\
\text { fost pecetea, care } \\
\text { lipsește }\end{array}$ \\
\hline 1019 & $\frac{7096}{1588}$ & februarie & 21 & $\begin{array}{l}\text { Cartea lui Petru voievod prin care < } \text { poruncește } \\
\text { pîrcălabilor de Hotin să aleagă hotarele }{ }^{290} \text { satului } \\
\text { Horbinești, care era stăpînit de Gavrilaș logofătul }{ }^{291}\end{array}$ & $\begin{array}{l}\text { slovenesc, cu trad. } \\
\text { românească }\end{array}$ \\
\hline 1020 & $\frac{7179}{1611}$ & februarie & 20 & $\begin{array}{l}\text { Cartea lui Constantin voievod prin care întărește } \\
\text { vînzarea unei părți din Holohoreni, făcută de către } \\
\text { Solomiia și fata ei, Mărica } \\
292\end{array}$ & $\begin{array}{l}\text { slovenesc, pe hîrtie, cu } \\
\text { trad. românească }\end{array}$ \\
\hline 1021 & $\frac{7119}{1611}$ & martie & 15 & $\begin{array}{l}\text { Cartea lui Constantin voieovd prin care întărește } \\
\text { vînzarea unei părți din Holohoreni, făcută de } \\
\text { Dumitru, fuul lui Hacico } \\
293\end{array}$ & " \\
\hline 1022 & $\frac{7119}{1611}$ & martie & 10 & $\begin{array}{l}\text { Cartea lui Constantin voievod prin care întărește } \\
\text { vînzarea unei părți din Holohoreni, făcută de } \\
\text { Ștefana, fata Grigăi }\end{array}$ & " \\
\hline 1023 & $\frac{7119}{1611}$ & - & - & $\begin{array}{l}\text { Cartea lui Constantin voievod prin care întărește } \\
\text { vînzarea unei părți din Holohoreni, făcută de } \\
\text { Vasilie și de sora lui, Mărica }{ }^{295}\end{array}$ & " \\
\hline 1024 & $\frac{7119}{1610}$ & noiembrie & 12 & $\begin{array}{l}\text { Cartea lui Constantin voievod prin care întărește } \\
\text { vînzarea unei părți din satul Holohoreni, făcută de } \\
\text { Călina și de surorile ei }{ }^{296}\end{array}$ & " \\
\hline 1025 & $\frac{7120}{1611}$ & decembrie & 17 & $\begin{array}{l}\text { Cartea lui Constantin voievod prin care întărește } \\
\text { vînzarea unei părți din satul Holohoreni, făcută de } \\
\text { Ionașco } \\
297\end{array}$ & " \\
\hline 1026 & $\frac{7120}{1611}$ & Decembrie & 17 & $\begin{array}{l}\text { Izvod de oameni care au vîndut satul Holohoreni, } \\
\text { pe Racovăț, în ținutul Hotinului }{ }^{298}\end{array}$ & " \\
\hline
\end{tabular}

\footnotetext{
${ }^{283} \operatorname{Boga}(1929$ c), p. 21-24, nr. XVII; MEF, I, p. 84-87, nr. 32;

${ }^{284}$ Boga (1929c), p. 29-30, nr. XXI (cu data de lună: „aprilie”).

${ }^{285}$ Boga (1929c), p. 30-31, nr. XXII; MEF, I, p. 105-106, nr. 42.

${ }^{286}$ În text, greșit: „Ion Sofronie comis”. Boga (1929c), p. 31-33, nr. XXIII; MEF, III, p. 92-94, nr. 43.

287 În text: „Volovoreni”.

${ }^{288}$ În text, greșit: „Petrașcu, fiul lui Grozav”. Boga (1929c), p. 33-35, nr. XXIV; MEF, I, p. 109-110, nr. 44.

${ }^{289}$ Boga (1929c), p. 38-42, nr. XXVIII (cu data de zi: „30”).

${ }^{290}$ În text, greșit: „întărește vânzarea”.

${ }^{291}$ Boga (1929c), p. 44-45, nr. XXX.

${ }^{292}$ Boga (1929f), p. 85-86, nr. IX; MEF, I, p. 261-262, nr. 113.

${ }^{293}$ Boga (1929f), p. 87-88, nr. X; MEF, I, p. 262-264, nr. 114.

${ }^{294}$ Boga (1929f), p. 88-89, nr. XI (cu data de zi: „20”).

${ }^{295}$ Boga (1929f), p. 90-91, nr. XII (fără dată de lună și zi); MEF, I, p. 259-260, nr. 112.

${ }^{296}$ Boga (1929f), p. 84-85, nr. VIII; MEF, I, p. 258-259, nr. 111.

${ }^{297}$ Boga (1929f), p. 90-92, nr. XIII; MEF, I, p. 279-281, nr. 124.

${ }^{298}$ MEF, III, p. 84-86, nr. 38.
} 


\begin{tabular}{|c|c|c|c|c|c|}
\hline 1027 & $\frac{7128}{1620}$ & martie & 28 & $\begin{array}{l}\text { Cartea lui Gașpar voievod prin care întărește } \\
\text { vînzarea unei părți din satul Holohoreni, făcută de } \\
\text { Maricuța }^{299}\end{array}$ & $\begin{array}{l}\text { slovenesc, pe hîrtie, cu } \\
\text { trad. românească }\end{array}$ \\
\hline 1028 & $\frac{7128}{1620}$ & Martie & 31 & $\begin{array}{l}\text { Cartea lui Gașpar voievod, dată lui Vasile Ureche } \\
\text { paharnic, pentru părțile lui de moșie din } \\
\text { Holohoreni }^{300}\end{array}$ & $\begin{array}{l}\text { românesc, pe hîrtie, cu } \\
\text { trad. rusească }\end{array}$ \\
\hline 1029 & $\frac{7152}{1644}$ & iunie & 12 & $\begin{array}{l}\text { Cartea lui Vasilie voievod, dată lui Borileanul } \\
\text { uricarul, pentru <a alege }>\text { o parte din Holohoreni, } \\
<\text { din ținutul Hotin }>301\end{array}$ & ” \\
\hline 1033 & $\frac{7167}{1659}$ & mai & 28 & $\begin{array}{l}\text { Cartea lui Grigorie Ghica voievod pentru } \\
\text { hotărnicirea satului Holohoreni }{ }^{302}\end{array}$ & ” \\
\hline 1034 & 1807 & iulie & 2 & $\begin{array}{l}\text { Cartea Divanului Moldovei în pricina clironomilor } \\
\text { lui Radu Boteanul }\end{array}$ & ” \\
\hline 1035 & - & noiembrie & 12 & Răvaș către Radul Boteanu în chestia unor bani ${ }^{303}$ & românesc, pe părțî3 \\
\hline 1036 & $\frac{7148}{1640}$ & aprilie & 12 & $\begin{array}{l}\text { Suret după cartea lui Vasilie voievod pentru } \\
\text { vînzarea unei părți din Răspopeni, < din ținutul } \\
\text { Soroca > } 305\end{array}$ & românesc \\
\hline 1037 & $\frac{7149}{1641}$ & ianuarie & 22 & $\begin{array}{l}\text { Suret după cartea lui Vasilie voievod pentru } \\
\text { vînzarea unei părți din Răspopeni, < din ținutul } \\
\text { Soroca > } 306\end{array}$ & ” \\
\hline 1038 & 1793 & octombrie & 7 & Alegerea moșiilor din Soroca ale lui Radul Boteanu & " \\
\hline 1039 & 1793 & octombrie & 13 & $\begin{array}{l}\text { Scrisoarea lui Iordache spătar către domn pentru } \\
\text { moștenirea lui Hermeziu }\end{array}$ & " \\
\hline 1040 & 1794 & iunie & 22 & Scrisoarea pentru alegerea moșiei Răspopenilor & ” \\
\hline 1041 & 1794 & octombrie & 14 & $\begin{array}{l}\text { Izvod de moșiile ce s-au venit în partea lui Ion } \\
\text { Zosin sluger }\end{array}$ & " \\
\hline 1042 & 1796 & octombrie & 27 & $\begin{array}{l}\text { Mărturia sătenilor din Răspopeni, < ținutul } \\
\text { Soroca }>\text {, cu privire la moștenirea lui <Grigoraș> } \\
\text { Hermeziu < postelnic }>307\end{array}$ & ” \\
\hline 1043 & 1796 & noiembrie & & $\begin{array}{l}\text { Hotărnicirea moșiei Răspopeni, < din ținutul } \\
\text { Soroca }>308\end{array}$ & ” \\
\hline 1044 & 1797 & mai & 6 & $\begin{array}{l}\text { Adeverința egumenului mănăstirii Bărboiul pentru } \\
\text { clironomia răposatului Radu Boteanul }\end{array}$ & ” \\
\hline 1045 & 1773 & mai & 16 & $\begin{array}{l}\text { Copie după împărțirea clironomilor lui Radu } \\
\text { Boteanu }\end{array}$ & ” \\
\hline 1046 & 1803 & iunie & 9 & $\begin{array}{l}\text { Copie după răvaşul către Mereacre în chestia unei } \\
\text { sume de bani }\end{array}$ & ” \\
\hline 1047 & 1810 & aprilie & 11 & $\begin{array}{l}\text { Chitanța de } 536<\text { lei>, semnată de un evreu, în } \\
\text { limba evreiască }\end{array}$ & ” \\
\hline 1048 & 1793 & septembrie & 23 & $\begin{array}{l}\text { Carte de blestem pentru alegerea moșiilor } \\
\text { clironomilor }<\text { lui > Grigoraș Hermeziul }^{309}\end{array}$ & ” \\
\hline 1049 & 1799 & decembrie & 18 & $\begin{array}{l}\text { Scrisoarea lui Vasilie Țărnă către domn pentru } \\
\text { hotarele moșiei Ciutești }\end{array}$ & ” \\
\hline 1050 & 1822 & martie & - & Mărturia lui Simion Grecul pentru spița Iablonschi & " \\
\hline 1051 & 1817 & - & - & Izvod de moșiile ce aparțin lui Mihail logofăt & ” \\
\hline
\end{tabular}

${ }^{299}$ Boga (1929f), p. 94-96, nr. XV.

${ }^{300}$ Boga (1929d), p. 11, nr. VII; MEF, I, p. 359-361, nr. 159.

${ }^{301}$ Boga (1929d), p. 28-29, nr. XXV.

${ }^{302} \mathrm{Boga}$ (1930c), p. 141-142, nr. VIII; MEF, IV, p. 286-297, nr. 128.

${ }^{303}$ Boga (1928b), p. 14, nr. VI (cu data de an: „1790”).

${ }^{304}$ În text: „hărți”.

${ }^{305}$ Boga (1929d), p. 22-23, nr. XXI (cu data de zi: „22”).

${ }^{306}$ Boga (1929d), p. 23-24, nr. XXII.

${ }^{307}$ Boga (1938a), p. 180-182, nr. LIII.

${ }^{308}$ Boga (1938a), p. 182-190, nr. LIV.

${ }^{309}$ Doc. T,.Mold., XI, p. 144-145, nr. 103. 


\begin{tabular}{|c|c|c|c|c|c|}
\hline 1052 & $\frac{7153}{1645}$ & martie & 7 & Certificat privitor la spița neamului Țărnă & " \\
\hline 1053 & $\frac{7138}{1629}$ & septembrie & - & $\begin{array}{l}\text { Suret scos după zapisul de vînzare a moșiei } \\
\text { Cornești }\end{array}$ & ” \\
\hline 1054 & 1799 & decembrie & 20 & $\begin{array}{l}\text { Răvașul lui Constantin Ipsilanti voievod pentru } \\
\text { cererea lui Țărnăă }\end{array}$ & " \\
\hline 1055 & $\frac{7252}{1744}$ & iunie & 3 & $\begin{array}{l}\text { Suret de pe o mărturie veche cu privire la moșia } \\
\text { Șendreni }\end{array}$ & ” \\
\hline 1056 & 1822 & - & - & Socoteala lui Darie Roșca, cu datornicii lui & ” \\
\hline 1057 & 1816 & martie & 3 & Planul moșiei Bogzăști & ” \\
\hline 1058 & 1827 & iunie & 8 & $\begin{array}{l}\text { Zapisul lui Pavel Maincovschi privitor la părțile } \\
<\text { din> Bogzăști ce le-a primit }\end{array}$ & $"$ \\
\hline 1059 & 1820 & noiembrie & 22 & $\begin{array}{l}\text { Zapisul lui Iordache Popovici pentru vînzarea unor } \\
\text { părți din Bogzăști }\end{array}$ & ” \\
\hline 1060 & 1823 & februarie & 24 & $\begin{array}{l}\text { Protestul lui Vasilie Roșca în pricina moșiei } \\
\text { Bogzăști }\end{array}$ & " \\
\hline 1061 & 1828 & ianuarie & 18 & $\begin{array}{l}\text { Mărturia lui „Răbaca” în chestia unor datorii ale lui } \\
\text { Hasnaș }\end{array}$ & " \\
\hline 1062 & 1809 & martie & 2 & Chitanța pentru 700 ruble a lui Cozlovschi & ” \\
\hline 1063 & 1772 & iunie & 3 & $\begin{array}{l}\text { Copie după răvașul lui Lupul Balș logofăt către } \\
\text { vornicul de < Colincăuți }>312\end{array}$ & " \\
\hline 1064 & $\frac{7179}{1671}$ & iulie & 13 & $\begin{array}{l}\text { Copie după mărturia lui Ursache vistiernic pentru a } \\
\text { treia parte din Culiceni, <din ținutul Hotin }>^{313}\end{array}$ & ” \\
\hline 1065 & 1810 & februarie & 21 & $\begin{array}{l}\text { Jalba răzeșilor din moșia Bezinul pentru hotarele } \\
\text { moșiei Bezinul }\end{array}$ & " \\
\hline 1066 & 1812 & mai & 20 & Mărturia Doniceștilor pentru moșia Bocșești ${ }^{314}$ & " \\
\hline 1067 & 1815 & - & - & $\begin{array}{l}\text { Hotărîrea Departamentului I-iu al oblastiei } \\
\text { Basarabia pentru moșia Isacova }\end{array}$ & " \\
\hline 1068 & 1804 & iunie & 17 & $\begin{array}{l}\text { Jalba lui Manolachi Băț către domn pentru moșia } \\
\text { Bezinul, <din ținutul Orhei> } 315\end{array}$ & " \\
\hline 1069 & $\frac{7229}{1720}$ & octombrie & 20 & $\begin{array}{l}\text { Zapisul lui Darie, nepotul lui Frațiman, prin care } \\
\text { vinde jumătate bătrăn, pe Ciuluc }\end{array}$ & " \\
\hline 1070 & $\frac{7143}{1635}$ & iunie & 15 & $\begin{array}{l}\text { Zapisul lui Berce pentru o parte din moșia } \\
\text { Brădeni }^{316}\end{array}$ & " \\
\hline 1071 & $\frac{7245}{1737}$ & februarie & 13 & $\begin{array}{l}\text { Zapisul Ștefancei pentru o parte din moșia } \\
\text { Brădeni }^{317}\end{array}$ & " \\
\hline 1072 & $\frac{7258}{1749}$ & decembrie & 9 & $\begin{array}{l}\text { Zapisul lui Enachi Bărgan pentru o parte din moșia } \\
\text { Brădeni }^{318}\end{array}$ & " \\
\hline 1073 & $\frac{7258}{1749}$ & decembrie & 9 & $\begin{array}{l}\text { Zapisul răzeșilor din Brădenii de Sus pentru partea } \\
<\text { seminției }^{319} \text { curgătoare }>\text { din Pavel < Grunzul }>320\end{array}$ & " \\
\hline 1074 & $\frac{7276}{1768}$ & iunie & 3 & $\begin{array}{l}\text { Mărturia hotarnică a moșiei Nebojinți, < din ținutul } \\
\text { Iași }>321\end{array}$ & " \\
\hline
\end{tabular}

\footnotetext{
${ }^{310} \mathrm{MEF}$, III, p. 259-262, nr. 116.

${ }^{311}$ Doc. T. Mold., XI, p. 325-326, nr. 262.

312 În text: „Calnicăuți”.

${ }^{313}$ MEF, VI, p. 65-66, nr. 11.

314 „Bucșăști” (ținutul Orhei). Vezi și Bacumenco (2006), p. 106.

${ }^{315}$ Doc. T. Mold., XII, p. 255-256, nr. 260.

${ }^{316}$ Boga (1932a), p. $148-149$, nr. IX.

${ }^{317}$ MEF, VIII, p. 138-139, nr. 103.

${ }^{318}$ MEF, VIII, p. 216-217, nr. 175.

319 În text: „scumției”.

${ }^{320}$ În text: „Gremțu”. MEF, VIII, p. 214-215, nr. 174.

${ }^{321}$ Boga (1938a), p. 75-77, nr. XXIX; Doc. T.. Mold., IX, p. 213-215, nr. 185.
} 


\begin{tabular}{|c|c|c|c|c|c|}
\hline 1075 & 1782 & februarie & 28 & $\begin{array}{l}\text { Mărturia lui Andrei „Născiu” pentru o parte din } \\
\text { moșia Brădeni }^{322}\end{array}$ & $”$ \\
\hline 1076 & 1785 & iunie & 3 & $\begin{array}{l}\text { Mărturia <hotarnică > prin care se arată <și> că } \\
\text { Iordache Hărjău a < <tăpînit > }{ }^{323} \text { o parte din } \\
\text { Brădeni, <ce se numește Măgura, din ținutul } \\
\text { Iași > } 324\end{array}$ & $"$ \\
\hline 1077 & 1785 & iunie & 6 & $\begin{array}{l}\text { Zapisul dat de Iordache Hărjău pentru o parte din } \\
\text { Brădeni }{ }^{325}\end{array}$ & $"$ \\
\hline 1078 & 1786 & septembrie & 21 & $\begin{array}{l}\text { Zapisul lui Bărgan pentru vînzarea unei părți din } \\
\text { Brădeni }^{326}\end{array}$ & $"$ \\
\hline 1079 & 1786 & decembrie & 8 & $\begin{array}{l}\text { Zapisul lui Gh. Bărgan pentru vînzarea unei părți } \\
\text { din Brădeni }\end{array}$ & $"$ \\
\hline 1080 & 1792 & iulie & 26 & $\begin{array}{l}\text { Zapisul lui Moisei Bărgan pentru vînzarea unei } \\
\text { părți din Brădeni }\end{array}$ & $"$ \\
\hline 1081 & $\begin{array}{l}<1723> \\
327\end{array}$ & iulie & 13 & $\begin{array}{l}\text { Cartea lui Mihail Racoviță voievod pentru o parte } \\
\text { de moșie din Brădeni }\end{array}$ & $”$ \\
\hline 1082 & 1811 & februarie & 7 & $\begin{array}{l}\text { Zapisul lui Ioan Bunescu pentru o parte din moșia } \\
\text { Măgura Mare }\end{array}$ & $"$ \\
\hline 1083 & 1811 & iulie & 2 & $\begin{array}{l}\text { Zapisul lui C. Bunescu pentru o parte din moșia } \\
\text { Măgura Mare }\end{array}$ & " \\
\hline 1084 & 1813 & decembrie & 31 & $\begin{array}{l}\text { Zapisul lui Costantin Roset spătar pentru o parte } \\
\text { din Măgura }\end{array}$ & $"$ \\
\hline 1085 & 1815 & maiu & 29 & $\begin{array}{l}\text { Porunca Isprăvniciei către Toader Brașovan de la } \\
\text { Măgura }\end{array}$ & $"$ \\
\hline 1086 & 1822 & octombrie & 30 & $\begin{array}{l}\text { Zapisul lui Ștefan Purcelean <și al altor > razeși prin } \\
\text { care vînd o parte din moșia Brădeni }\end{array}$ & $"$ \\
\hline 1087 & 1816 & august & 4 & $\begin{array}{l}\text { Porunca Departamentului I-iu către Isprăvnicia Iași } \\
\text { pentru hotărnicirea moșiei Măgurelele }\end{array}$ & $"$ \\
\hline 1088 & 1817 & februarie & 14 & Raportul Isprăvniciei Iași către Andrei Balș & ” \\
\hline 1089 & 1817 & februarie & 27 & $\begin{array}{l}\text { Raportul hotarnicilor pentru hotarul moșiei } \\
\text { Brădeni }\end{array}$ & $"$ \\
\hline 1090 & 1817 & septembrie & 20 & $\begin{array}{l}\text { Mărturia <răzeșilor }{ }^{328} \text { pentru hotarele moșiei } \\
\text { Brădeni }\end{array}$ & $"$ \\
\hline 1091 & 1817 & decembrie & 20 & $\begin{array}{l}\text { Zapisul răzeșilor moșiei Brădeni pentru o parte din } \\
\text { moșie }\end{array}$ & $”$ \\
\hline 1092 & 1820 & noiembrie & 30 & $\begin{array}{l}\text { Hotărîrea Judecătoriei ținutului Iași în pricina } \\
\text { moșiei Brădeni }\end{array}$ & ” \\
\hline 1093 & 1821 & ianuarie & 31 & $\begin{array}{l}\text { Povestca Judecătoriei ținutului Iași către Vasilie } \\
<\text { Șafirov }{ }^{329} \text { pentru moșia Brădeni }\end{array}$ & ” \\
\hline 1094 & 1824 & octombrie & 16 & Copia ucazului pentru moșia Brădeni & " \\
\hline 1095 & 1822 & iulie & 7 & $\begin{array}{l}\text { Socoteala tovărășiei între Gani și Botescu în } \\
\text { cincisprezece piese }\end{array}$ & ” \\
\hline 1096 & 1826 & martie & 10 & $\begin{array}{l}\text { Mărturia „Crestei Clasanarilor”330 din Iași cu } \\
\text { privire la obiceiurile datornicilor }\end{array}$ & " \\
\hline 1097 & 1826 & martie & 16 & $\begin{array}{l}\text { Răvașul lui Dumitru Gh. Mihail către Hagi Ganciu } \\
\text { de la Iași }\end{array}$ & " \\
\hline
\end{tabular}

\footnotetext{
${ }^{322}$ Doc. T. Mold., X, p. 136, nr. 96.

${ }^{323}$ În text, greșit: „vîndut”.

${ }^{324}$ Boga (1938a), p. 116-117, nr. XLI.

${ }^{325}$ Doc. T. Mold., X, p. 194-195, nr. 147.

${ }^{326}$ Doc. T. Mold., X, p. 233, nr. 186.

${ }^{327}$ În text data greșită: „1793”.

${ }^{328}$ În text: „breveștilor”.

${ }^{329}$ În text: „Safitorv”.

${ }^{330}$ Așa în text.
} 


\begin{tabular}{|c|c|c|c|c|c|}
\hline 1098 & 1817 & octombrie & 26 & $\begin{array}{l}\text { Mărturia lui Nicolae Hagi Dobic pentru nişte } \\
\text { zapise }\end{array}$ & ” \\
\hline 1099 & 1804 & decembrie & 10 & $\begin{array}{l}\text { Zapisul „proectului”331 Isacova pentru o parte de } \\
\text { loc }\end{array}$ & ” \\
\hline 1100 & 1803 & noiembrie & 19 & Zapisul Saftei Postolache pentru o moară & " \\
\hline 1101 & 1818 & iunie & 25 & $\begin{array}{l}\text { Zapisul lui Gh. Lungu pentru o parte din moșia } \\
\text { Isacova }\end{array}$ & $"$ \\
\hline 1102 & 1804 & mai & 8 & $\begin{array}{l}\text { Porunca Isprăvniciei către mai mulți răzeși în } \\
\text { pricina moșiei Isacova }\end{array}$ & ” \\
\hline 1103 & 1804 & mai & 28 & $\begin{array}{l}\text { Porunca }<\text { Sărdăriei }{ }^{332} \text { către Iordache Coroțchi în } \\
\text { pricina moșiei Isacova }\end{array}$ & ” \\
\hline 1104 & - & - & - & $\begin{array}{l}\text { Mărturia răzeșilor cu privire la veniturile moșiei } \\
\text { Isacova }\end{array}$ & ” \\
\hline 1105 & 1823 & aprilie & 23 & Socoteala de veniturile moșiei Trifești & ” \\
\hline 1106 & 1823 & august & 27 & Mărturia veniturilor moșiei Trifești & ” \\
\hline 1107 & 1826 & - & - & $\begin{array}{l}\text { Chitanțe iscălite de Petru Emanoil, în nouă } \\
\text { exemplare }\end{array}$ & ” \\
\hline 1108 & 1797 & august & 4 & Mărturia hotarnică a moșiei Ghermănești ${ }^{333}$ & ” \\
\hline 1109 & $\frac{7260}{1752}$ & iunie & 13 & $\begin{array}{l}\text { Mărturia hotarnică pentru moșia < din gura } \\
\text { ocoalelor sub Obrăjie } 334\end{array}$ & dată suspectăă 35 \\
\hline 1110 & 1817 & Iulie & 31 & Mărturia răzeșilor cu privire la moșia Ghermănești & romînesc \\
\hline 1112 & 1817 & iulie & 25 & Spița neamului ce stăpînește moșia Leușeni ${ }^{336}$ & ” \\
\hline 1113 & 1818 & ianuarie & 8 & Mărturia dată răzeșilor de Glodeni & \\
\hline 1114 & 1822 & octombrie & 18 & Mărturia dată răzeșilor din Ghermănești & ” \\
\hline 1115 & 1778 & iunie & 12 & $\begin{array}{l}\text { Zapisul lui Chirică Ion pentru o parte din moșia } \\
\text { Frăsinești }\end{array}$ & " \\
\hline 1116 & 1814 & ianuarie & 25 & $\begin{array}{l}\text { Hotărîrea Departamentului Pricinilor Streine în } \\
\text { pricina fraților Bahrinești }\end{array}$ & $\begin{array}{l}\text { românesc, cu trad. } \\
\text { rusească }\end{array}$ \\
\hline 1117 & 1797 & decembrie & 7 & Zestrea ce dă Fotina șătrăreasca fiicei ${ }^{337}$ & " \\
\hline 1118 & 1590 & octombrie & 18 & $\begin{array}{l}\text { Zestrea ce dă „Milur” pentru moșia Cimincăuții }{ }^{338} \\
\text { (copie) }\end{array}$ & dată suspectă ${ }^{339}$ \\
\hline 1119 & - & - & - & $\begin{array}{l}\text { Zapisul lui Nicolae pentru moșia lui <din > } \\
\text { Cioropceni }\end{array}$ & românesc \\
\hline 1120 & 1820 & august & 26 & Izvod de zapisele moșiilor ce aparțin lui Iacovachi & " \\
\hline 1121 & $\frac{7258}{1749}$ & septembrie & 20 & $\begin{array}{l}\text { Copie. Scrisoarea lui Ursu pîrcălabul Hotinului } \\
\text { pentru <moșia Gangura, din ținutul Lăpușna > } 340\end{array}$ & " \\
\hline 1122 & 1824 & mai & 31 & $\begin{array}{l}\text { Mărturia lui Neculai Buzni pentru veniturile moșiei } \\
\text { Soltănești }\end{array}$ & ” \\
\hline 1123 & 1825 & aprilie & 22 & Scrisoarea lui Rali ${ }^{341}$ către cucoana Zamfiriţa & " \\
\hline 1124 & 1824 & ianuarie & 19 & Chitanța de lei 4.800 a lui <Zamfirachi > Rali & ” \\
\hline 1125 & 1825 & mai & 10 & Mărturia privitoare la veniturile moșiei Soltănești & copie \\
\hline 1126 & 1825 & ianuarie & 19 & $\begin{array}{l}\text { Scrisoarea lui <Zamfirachi > Rali, < din Chișinău >, } \\
\text { către cucoana Zamfirița, <la Văsieni > } 342\end{array}$ & românesc \\
\hline
\end{tabular}

\footnotetext{
${ }^{331}$ Așa în text.

${ }^{332}$ În text: „Săpdaniei”.

${ }^{333}$ Doc. T.. Mold., XI, p. 261, nr. 198.

${ }^{334}$ În text: „Obrajela”. Boga (1938a), p. 42-44, nr. XVIII; Doc. T,.Mold., IX, p. 28-29, nr. 7.

${ }^{335}$ Data este corectă, pentru că în text este menționat Radu Racoviță mare vistier, stăpînul de atunci al satului.

${ }^{336}$ În text: „Bleușeni”.

${ }^{337}$ Boga (1928a), p. 11-12, nr. V.

${ }^{338}$ Probabil: „Citnicăuți”.

${ }^{339}$ Probabil documentul este de la sfîrșitul secolului al XVIII-lea (1790).

${ }^{340}$ În text, greșit: „Gheorghiță”. Boga (1938a), p. 41-42, nr. XVII.

${ }^{341}$ În text, greșit: „Hali”.

${ }^{342}$ În documentul publicat: „Ghijdeu”. Boga (1928b), p. 97-98, nr. CXXVII.
} 


\begin{tabular}{|c|c|c|c|c|c|}
\hline 1127 & 1825 & aprilie & 23 & $\begin{array}{l}\text { Scrisoarea lui <Zamfirachi > Rali către cucoana } \\
\text { Zamfira }\end{array}$ & ” \\
\hline 1128 & 1817 & martie & 5 & $\begin{array}{l}\text { Chitanța Epitropiei moșiei tîrgului Chișinău prin } \\
\text { care se dă voie lui Stratulat a-și face o grădină }\end{array}$ & ” \\
\hline 1129 & 1805 & mai & 8 & $\begin{array}{l}\text { Cererea lui Solomon din Chișinău prin care cere să } \\
\text { i se dea zestrea lui }\end{array}$ & $\begin{array}{l}\text { românesc, cu } 2 \text { acte } \\
\text { evreiești }\end{array}$ \\
\hline 1130 & 1822 & mai & 27 & $\begin{array}{l}\text { Cererea lui Tomov către Tribunal pentru niște bani } \\
\text { ce are de luat }\end{array}$ & rusesc \\
\hline 1131 & 1821 & aprilie & 8 & $\begin{array}{l}\text { Contract de arendare a unei livezi de către „Colos” } \\
\text { Bogdasarov }\end{array}$ & românesc \\
\hline 1132 & 1821 & august & 23 & $\begin{array}{l}\text { Contract de închiriere a caselor lui „Gulac”343 din } \\
\text { Chișinău }\end{array}$ & ” \\
\hline 1133 & 1806 & ianuarie & 29 & Izvod de zestrea ce se dă Elenei de către frații ei & ” \\
\hline 1134 & 1818 & iunie & 30 & $\begin{array}{l}\text { Zapisul lui Grigorie Sulă prin care vinde o bucată de } \\
\text { loc în Scorțeni }\end{array}$ & ” \\
\hline 1135 & 1821 & iunie & 24 & Contractul lui M. Răuleț pentru moșia „Muncii” ${ }^{444}$ & ” \\
\hline 1136 & 1808 & iulie & 10 & $\begin{array}{l}\text { Actul de vînzare a unei grădini, făcut de Catrina } \\
\text { Sulă }\end{array}$ & " \\
\hline 1137 & 1824 & ianuarie & 11 & Izvod de documenturile ce a înfățișat Mihailovici & ” \\
\hline 1138 & 1825 & aprilie & 23 & $\begin{array}{l}\text { Contractul de vînzare a venitului moșiei „Isaicani” } \\
\text { de Mihai Covici }\end{array}$ & ” \\
\hline 1139 & 1827 & - & - & $\begin{array}{l}\text { Chitanțe de diferite sume, iscălite de Suruceanu ( } 28 \\
\text { bucăți) }\end{array}$ & " \\
\hline 1140 & 1793 & mai & 20 & $\begin{array}{l}\text { Cartea lui Mihai Suțu voievod, dată lui Climent, de } \\
\text { cumpărare a unei case la Iași }\end{array}$ & ” \\
\hline 1141 & 1792 & septembrie & 7 & $\begin{array}{l}\text { Zapisul de vînzare a unei case din Iași, făcut de } \\
\text { Toade Carp lui Climent }\end{array}$ & ” \\
\hline 1142 & 1776 & mai & 11 & $\begin{array}{l}\text { Cartea lui Grigore Ghica voievod pentru niște } \\
\text { datorii ale lui Dimitrie Arghir cupeț }\end{array}$ & ” \\
\hline 1143 & $\frac{7242}{1733}$ & noiembrie & 2 & $\begin{array}{l}\text { Zapisul Saftei Alevra, dat lui Arghir, pentru o } \\
\text { casă }^{345}\end{array}$ & ” \\
\hline 1144 & 1803 & septembrie & 12 & $\begin{array}{l}\text { Cartea lui Veniamin mitropolitul Moldovei, dată } \\
\text { Ilenei, soția lui Clement, pentru vînzarea unei } \\
\text { case }^{346}\end{array}$ & ” \\
\hline 1145 & 1803 & iulie & 25 & $\begin{array}{l}\text { Cererea Ilenei Climentoaei pentru o cîrciumă de } \\
\text { piatră }\end{array}$ & ” \\
\hline 1146 & 1823 & decembrie & 22 & $\begin{array}{l}\text { Zapisul lui Ioan Purcel prin care vinde o bucată de } \\
\text { loc din moșia Movileni }\end{array}$ & ” \\
\hline 1147 & 1819 & iunie & 22 & Zapisul Mariei sărdăreasa prin care vinde două livezi & " \\
\hline 1148 & 1820 & - & - & $\begin{array}{l}\text { Zece bilanțuri, în grecește, privitoare la mersul unei } \\
\text { afaceri }\end{array}$ & grecesc \\
\hline 1149 & 1823 & decembrie & 13 & $\begin{array}{l}\text { Permis pentru a merge la Odesa <pentru> } \\
\text { Gheorghe Chiriadji }\end{array}$ & rusesc \\
\hline 1150 & 1832 & martie & 5 & Scrisoarea către D. Ivanovici în chestie de bani & ” \\
\hline 1151 & 1830 & - & - & Chitanța lui Sechiraș pentru 2.000 ruble & rusesc \\
\hline 1152 & 1822 & septembrie & 23 & $\begin{array}{l}\text { Contract de arendare a moșiilor „Blindeiul” }{ }^{347}<s ̦ i> \\
\text { „Scutești” ale lui Constantin Bantăș }\end{array}$ & românesc \\
\hline 1153 & 1824 & aprilie & 3 & $\begin{array}{l}\text { Copie după contractul de arendare a moșiei } \\
\text { „Blăndeiul” }\end{array}$ & ” \\
\hline
\end{tabular}

\footnotetext{
${ }^{343}$ Probabil: „Ciolac”.

${ }^{344}$ Poate „Muncești” (ținutul Orhei).

${ }^{345}$ MEF, VIII, p. 125, nr. 94 (cu data de zi: „12”).

${ }^{346}$ Doc. T. Mold., XII, p. 200-201, nr. 196.

${ }^{347}$ Poate „Blândești”.
} 


\begin{tabular}{|c|c|c|c|c|c|}
\hline 1154 & 1824 & iulie & 28 & $\begin{array}{l}\text { Scrisoarea lui Costache Ciornei către logofătul } \\
<\text { Toader }>^{348} \text {, pentru } 800 \text { de lei }^{349}\end{array}$ & ” \\
\hline 1155 & 1827 & august & 27 & $\begin{array}{l}\text { Scrisoarea lui < Rusu, din T, Tigănești > către Criste, } \\
\text { <la Teleșău >, cu privire la o judecată } 350\end{array}$ & $"$ \\
\hline 1156 & 1827 & septembrie & 3 & $\begin{array}{l}\text { Scrisoarea lui Roset < medelnicer > în pricina unor } \\
\text { țigani }{ }^{351}\end{array}$ & ” \\
\hline 1157 & 1823 & iunie & 6 & Chitanța lui Roset pentru 1.572 lei & ” \\
\hline 1158 & 1819 & mai & 20 & Chitanța lui C. Bagdasarov pentru 5.000 lei & rusesc \\
\hline 1159 & 1820 & ianuarie & 6 & Atestat de terminarea serviciului a lui Barbașev & 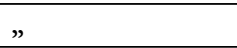 \\
\hline 1160 & 1825 & martie & 4 & Două chitanțe de primirea zapiselor de cumpărare & românesc \\
\hline 1161 & - & - & - & $\begin{array}{l}\text { Chitanțele lui Murguleț pentru diverse sume ( } 5 \\
\text { bucăți) }\end{array}$ & ” \\
\hline 1162 & 1823 & iulie & - & $\begin{array}{l}\text { Patru acte evreiești privitoare la pricina ce o are } \\
\text { Lipa Strulovici }\end{array}$ & $\begin{array}{l}\text { evreiește, cu trad. } \\
\text { rusească }\end{array}$ \\
\hline 1163 & 1819 & octombrie & 30 & $\begin{array}{l}\text { Chitanțele lui Vorfolomei pentru diverse sume de } \\
\text { bani }\end{array}$ & românesc \\
\hline 1164 & 1821 & martie & 20 & $\begin{array}{l}\text { Mărturia creditorilor lui Vasile Buruiană cu privire } \\
\text { la datoriile lui }\end{array}$ & ” \\
\hline 1165 & 1828 & februarie & 2 & Contract de arendare a moșiei $<$ Cornova $>^{352}$ & ” \\
\hline 1166 & 1828 & - & - & Chitanțele lui „Haihul” de diferite sume (15 bucăți) & ” \\
\hline 1167 & 1828 & februarie & 14 & Polița lui Șvartzman pentru 90 ruble argint & " \\
\hline 1168 & 1821 & august & 4 & $\begin{array}{l}\text { Zapisul lui Grigorie David pentru vînzarea unui loc } \\
\text { din Stolniceni }\end{array}$ & " \\
\hline 1169 & 1820 & decembrie & 27 & Scrisoarea lui Tumanov către „Aron Bei” & rusesc \\
\hline 1170 & 1821 & ianuarie & 5 & Chitanța de 800 lei semnată de Leca & românesc \\
\hline 1171 & 1820 & aprilie & 2 & $\begin{array}{l}\text { Scrisoarea de învoială între Abaza Manoli și } \\
\text { Papadopol }\end{array}$ & grecesc. \\
\hline 1172 & 1823 & ianuarie & 21 & $\begin{array}{l}\text { Izvod de zestrea ce se dă Vasilcăi, fata lui Raico } \\
\text { Gavrilovici }\end{array}$ & românesc \\
\hline 1173 & 1817 & noiembrie & - & $\begin{array}{l}\text { Cererea lui Bercovici în pricina ce o are cu Sava } \\
\text { cizmarul }\end{array}$ & rusesc, evreiesc \\
\hline 1174 & - & - & - & Izvod de documentele lui Bașotă & românesc \\
\hline 1175 & 1817 & iunie & 6 & Zapisul lui Șmil Meer pentru vînzarea unei dugheni & ” \\
\hline 1176 & 1818 & octombrie & 26 & Zapisul de vînzare a unei dugheni a lui „Grați” & " \\
\hline 1177 & 1817 & august & 18 & Cartea de învoială între Stefan Nicolau şi Panaioti & românesc, copie \\
\hline 1178 & - & - & - & $\begin{array}{l}\text { Izvod de marfă, aflată la învoiala între Nicolau și } \\
\text { Panaioti }\end{array}$ & grecesc \\
\hline 1179 & 1824 & mai & 19 & $\begin{array}{l}\text { Raportul poliției Achermanului în pricina unor } \\
\text { căruțe }\end{array}$ & românesc \\
\hline 1180 & 1824 & mai & 18 & Idem & ” \\
\hline 1181 & 1824 & iunie & 25 & $\begin{array}{l}\text { Raportul Biroului Poștelor în pricina unor căruțe } \\
\text { stricate }\end{array}$ & $"$ \\
\hline 1182 & 1827 & iunie & 30 & $\begin{array}{l}\text { Mărturie de primirea a } 80 \text { lei, luați de Costache } \\
\text { Erhan }\end{array}$ & \\
\hline 1183 & 1827 & decembrie & 1 & $\begin{array}{l}\text { Mărturia cătorva locuitori din Chișinău în pricina } \\
\text { lui Ioniță Corman }\end{array}$ & ” \\
\hline 1184 & 1818 & mai & 3 & $\begin{array}{l}\text { Zapisul de vînzare a lui Matei tabacar din Chișinău } \\
\text { pentru o dugheană }\end{array}$ & $"$ \\
\hline
\end{tabular}

\footnotetext{
${ }^{348}$ În text, greșit: „Pordeni”.

${ }^{349} \mathrm{Boga}$ (1928b), p. 103-104, nr. CXXXV.

${ }^{350}$ Boga (1928b), p. 118, nr. CLVI.

${ }^{351}$ Boga (1928b), p. 119, nr. CLVII.

352 In text: „Vornova”.

${ }^{353}$ Boga (1928a), p. 31-33, nr. XXI.
} 


\begin{tabular}{|c|c|c|c|c|c|}
\hline 1185 & 1817 & februarie & - & $\begin{array}{l}\text { Cererea lui }<\text { Manase }>^{354} \text { ieromonah privitor la } \\
\text { niște bani }\end{array}$ & " \\
\hline 1186 & 1823 & martie & 23 & $\begin{array}{l}\text { Discursul }^{355} \text { lui Gheorghe „Hamargan” către } \\
\text { Vasilie Bonciu pentru niște datorii }\end{array}$ & românesc \\
\hline 1187 & 1822 & octombrie & 30 & $\begin{array}{l}\text { Mărturia cîtorva locuitori din Chișinău privitoare } \\
\text { la datoria lui Moșco Leibovici }\end{array}$ & rusesc \\
\hline 1188 & 1820 & - & - & Chitanța de diferite sume luate de „Sală” (15 bucăți) & românesc și rusesc \\
\hline 1189 & 1813 & - & - & $\begin{array}{l}\text { Chitanțe pentru diverse sume semnate de } \\
\text { Constantin Armaș ( } 5 \text { piese) }\end{array}$ & românesc \\
\hline 1190 & 1828 & iunie & 8 & $\begin{array}{l}\text { Zapisul lui Apostol Hănganu pentru o parte din } \\
\text { moșia <Leușeni > }{ }^{356} \text { Reușeni }\end{array}$ & $”$ \\
\hline 1191 & $\frac{7174}{1766}$ & iunie & 6 & $\begin{array}{l}\text { Zapisul lui „Hubabă” pentru o parte din } \\
\text { „Alioșeni” } 357\end{array}$ & " \\
\hline 1192 & 1820 & noiembrie & 25 & Scrisoarea către Suruceanu privitoare la niște datorii & ” \\
\hline 1193 & 1831 & septembrie & 28 & Chitanțe de 100 ducați împrumutați de „Jună” & francez \\
\hline 1194 & 1821 & martie & - & Tablou de vitele aflate în ținutul Ismailului & rusesc \\
\hline 1195 & 1819 & iunie & 15 & $\begin{array}{l}\text { Certificat dat lui „Felios” de buna lui purtare în } \\
\text { serviciu }\end{array}$ & $”$ \\
\hline 1196 & 1820 & iunie & 15 & Certificat dat lui „Felios” de buna lui purtare ${ }^{358}$ & ” \\
\hline 1197 & $\frac{7175}{1727}$ & iunie & 23 & $\begin{array}{l}\text { Referatul marelui logofăt privitor la moșia lui } \\
\text { „Coculescu” }\end{array}$ & " \\
\hline 1198 & 1800 & mai & 12 & $\begin{array}{l}\text { Scrisoarea lui Coculescu către caimacam privitoare } \\
\text { la o mărturie din } 1735\end{array}$ & ” \\
\hline 1199 & 1791 & mai & 18 & $\begin{array}{l}\text { Zapisul lui Gheorghe Hărjău pentru arenda moșiei } \\
<\text { Răcești }>359\end{array}$ & ” \\
\hline 1200 & 1772 & - & - & Izvod de moșiile lui Leca Jardanul & grecesc \\
\hline 1201 & 1803 & martie & 6 & Jalba stolnicului Iordache pentru satul <Răcești $>$ & românesc \\
\hline 1202 & 1803 & martie & 17 & $\begin{array}{l}\text { Cartea lui Alexandru Moruzi voievod către } \\
\text { Manolache Donici pentru satul }<\text { Răcești, din } \\
\text { ținutul Soroca }>360\end{array}$ & ” \\
\hline 1203 & 1803 & martie & 15 & Referatul boierilor privitor la hotarele Răceștilor ${ }^{361}$ & ” \\
\hline 1204 & 1799 & ianuarie & 12 & $\begin{array}{l}\text { Porunca lui Alexandru Calimah voievod către } \\
\text { ispravnicii Sorocii pentru moșia Răceștii } \\
{ }^{362}\end{array}$ & " \\
\hline 1205 & 1804 & februarie & 28 & $\begin{array}{l}\text { Porunca logofătului către Isprăvnicia de Soroca } \\
\text { pentru moșia Răcești }\end{array}$ & ” \\
\hline 1206 & 1804 & februarie & 28 & $\begin{array}{l}\text { Jalba lui C. Poleologu către domn pentru moșia } \\
\text { Răcești }\end{array}$ & $”$ \\
\hline 1207 & 1804 & ianuarie & 31 & $\begin{array}{l}\text { Scrisoarea către Grigorie Ghica biv vel „portar”364 } \\
\text { pentru moția Răcești }\end{array}$ & " \\
\hline 1208 & 1804 & aprilie & 10 & $\begin{array}{l}\text { Mărturia răzeșilor din Răcești pentru bătrînul } \\
\text { Armașul }\end{array}$ & " \\
\hline 1209 & 1804 & iunie & 2 & $\begin{array}{l}\text { Cartea lui Alexandru Moruzi voievod cu privire la } \\
\text { moșia Răcești }\end{array}$ & $"$ \\
\hline
\end{tabular}

\footnotetext{
${ }^{35}$ '̂̂n text: „Menașe”.

${ }^{355}$ Așa în text.

${ }^{356}$ În text: „Reușeni”.

${ }^{357}$ Poate „Alicșeni” (vezi documentul din 11 iunie 1766; Doc. Ţ. Mold., IX, p. 185-186, nr. 159).

${ }^{358} \mathrm{Nu}$ ar fi exclus să fie vorba despre același act, rezumat de două ori, sub date de an diferite.

${ }^{359}$ În text: „Rărești”. Doc. T,.Mold., XI, p. 94, nr. 41.

${ }^{360}$ Doc. T,. Mold., XII, p. 146, nr. 125.

${ }^{361}$ Boga (1938a), p. 242-244, nr. LXV (cu data de lună: „august”).

${ }^{362}$ Doc. T. Mold., XI, p. 307, nr. 243.

${ }^{363}$ Cred că este de fapt porunca domnească, la sfîrșitul căreia este menționat și marele logofăt; Doc. Ț.Mold., XII, p. 234235, nr. 237.

${ }^{364}$ Lectură greșită; probabil, postelnic sau paharnic.
} 


\begin{tabular}{|c|c|c|c|c|c|}
\hline 1210 & 1804 & iunie & 10 & $\begin{array}{l}\text { Mărturia boierilor cu privire la hotarele moșiei } \\
\text { Răcești }\end{array}$ & $"$ \\
\hline 1211 & 1804 & august & 12 & Planul satului Răcești: 5 exemplare $^{365}$ & ” \\
\hline 1212 & - & - & - & $\begin{array}{l}\text { Mărturia hotarnică a moșiei Răcești, < din ținutul } \\
\text { Soroca }>366\end{array}$ & $"$ \\
\hline 1213 & 1796 & mai & 11 & Zapisul lui Simion pentru o parte din moșia Răcești & 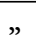 \\
\hline 1214 & - & - & - & $\begin{array}{l}\text { Zapisul lui Apostol pentru o parte din moșia } \\
\text { Răcești }\end{array}$ & $"$ \\
\hline 1215 & 1800 & septembrie & 8 & $\begin{array}{l}\text { Zapisul sătenilor moșiei Răcești prin care se obligă } \\
\text { a-i lucra lui Paleologu zilele boierescului }\end{array}$ & $"$ \\
\hline 1216 & 1806 & mai & 14 & $\begin{array}{l}\text { Mărturia vechilului satului „Domura” pentru unii } \\
\text { răzeși din Răcești }\end{array}$ & $"$ \\
\hline 1217 & 1808 & iunie & 30 & $\begin{array}{l}\text { Porunca Isprăvniciei Soroca pentru o parte din } \\
\text { Răcești a lui Tudorache Sava }\end{array}$ & $"$ \\
\hline 1218 & 1806 & iunie & 12 & $\begin{array}{l}\text { Răvașul Isprăvniciei Soroca pentru o parte din } \\
\text { Răcești a lui Tudorache Sava }\end{array}$ & $"$ \\
\hline 1219 & 1807 & iunie & 20 & $\begin{array}{l}\text { Răvașul Isprăvniciei Soroca către Tudorache Sava } \\
\text { pentru partea lui din Răcești }\end{array}$ & $"$ \\
\hline 1230 & 1807 & iunie & 20 & $\begin{array}{l}\text { Răvașul Isprăvniciei Soroca către Tudorache Sava } \\
\text { pentru partea din Răcești }{ }^{367}\end{array}$ & $"$ \\
\hline 1231 & $\frac{7264}{1756}$ & iunie & 11 & $\begin{array}{l}\text { Jalba lui Constantin „Mehelnicu”368 pentru moșia } \\
\text { din Răcești }\end{array}$ & " \\
\hline 1232 & 1807 & iulie & 6 & $\begin{array}{l}\text { Hotărîrea Departamentului Pricinilor Dinafară cu } \\
\text { privire la moșia Răcești }{ }^{369}\end{array}$ & $"$ \\
\hline 1233 & 1806 & - & - & Jalba lui Iordache „Buzăca” pentru moșia Hruțca ${ }^{370}$ & \# \\
\hline 1234 & 1815 & octombrie & 31 & Referatul Sărdăriei cu privire la moșia Hruțca & " \\
\hline 1235 & 1816 & februarie & 9 & $\begin{array}{l}\text { Raportul de la căpitanul de mazili din < Lucavăț }>^{371} \\
\text { pentru moșia Hruțca }\end{array}$ & $"$ \\
\hline 1236 & 1817 & iunie & 12 & $\begin{array}{l}\text { Porunca Sărdăriei către Iordache „Buzalău” pentru } \\
\text { moșia Hruțca }\end{array}$ & $"$ \\
\hline $\begin{array}{c}1236 \\
372\end{array}$ & 1816 & octombrie & 27 & $\begin{array}{l}\text { Hotărîrea Departamentului I-iu cu privire la moșia } \\
\text { Hruțca }\end{array}$ & $"$ \\
\hline 1237 & 1813 & februarie & 3 & Mărturia dată de la gubernator lui Tușenco & " \\
\hline 1238 & 1820 & martie & 12 & Scrisoarea lui Bulgac către Ioan Chirilovici & " \\
\hline 1239 & $\begin{array}{l}\frac{7224}{1716} \\
373\end{array}$ & iulie & 23 & Cartea lui Mihai Racoviță voievod ${ }^{374}$ & " \\
\hline 1240 & - & - & - & $\begin{array}{l}\text { Zapisul lui Stratul „Borel” pentru o parte din } \\
\text { Zubrești }\end{array}$ & " \\
\hline 1241 & - & - & - & $\begin{array}{l}\text { Zapisul lui Ioniță Costin pentru o parte din } \\
\text { Zubrești }\end{array}$ & ” \\
\hline 1242 & 1805 & august & 22 & $\begin{array}{l}\text { Mărturia lui Filip postelnic pentru niște scrisori } \\
\text { vechi }\end{array}$ & ” \\
\hline 1243 & - & - & - & Zapisul lui Pleșca pentru o parte din Zubrești & " \\
\hline 1244 & 1819 & martie & 7 & Socoteala pentru o parte din Trifeni & " \\
\hline
\end{tabular}

${ }^{365}$ Din această zi s-a păstrat și s-a publicat o mărturie hotarnică pentru „bătrînul” Armașul din moșia Răcești, stăpînit de medelnicerul Costache Paleologu; Boga (1938a), p. 245-248, nr. LXVI.

${ }^{366}$ Boga (1938a), p. 173-176, nr. LI (cu data: „11 mai 1796”, identică cu a documentului următor din această listă).

${ }^{367}$ Probabil este vorba despre același act, rezumat de două ori.

${ }^{368}$ Probabil: „medelnicer”.

${ }^{369}$ Doc. T. Mold. (2016), p. 64-67, nr. 70.

370 „Hreațca”.

${ }^{371}$ În text: „Bucavăț”.

${ }^{372}$ Număr dublat.

${ }^{373}$ În text, data greșită: 1756 (7264)".

${ }^{374}$ Boga (1930a), p. 348, 355-356, nr. XI (carte domnească pentru moșiile Zubrești și Tătărești, din ținutul Orhei). 


\begin{tabular}{|c|c|c|c|c|c|}
\hline 1245 & 1819 & mai & 28 & $\begin{array}{l}\text { Scrisoarea lui <Măcărescu > }{ }^{375} \text { către Giani <Glipsis }> \\
\text { pentru un țăran din Ciuciuleni }\end{array}$ & $"$ \\
\hline 1246 & 1792 & august & 10 & $\begin{array}{l}\text { Zapisul lui Axinte prin care vinde o moară la } \\
\text { Slobozia Dușcăi }\end{array}$ & $"$ \\
\hline 1247 & 1805 & martie & 14 & $\begin{array}{l}\text { Zapisul lui Axinte Măricuță prin care vinde un vad } \\
\text { de moară la Lucaceuca }{ }^{377}\end{array}$ & $"$ \\
\hline 1248 & - & - & - & $\begin{array}{l}\text { Zapisul lui Gheorghe „Stabi” prin care vinde un vad } \\
\text { de moară }\end{array}$ & $"$ \\
\hline 1249 & 1726 & mai & 16 & $\begin{array}{l}\text { Mărturia locuitorilor din „Sibiceni” }{ }^{378} \text { pentru un } \\
\text { vad de moară }\end{array}$ & $"$ \\
\hline 1250 & $\frac{7264}{1755}$ & noiembrie & 23 & $\begin{array}{l}\text { Zapisul răzeșilor din Sireți, }<\text { din ținutul Lăpușna }>\text {, } \\
\text { pentru o parte din moșiile lor }<\text { din acest sat }>379\end{array}$ & " \\
\hline 1251 & $\frac{7232}{1723}$ & septembrie & 20 & $\begin{array}{l}\text { Zapisul lui Lazăr Lupul pentru o parte din } \\
\text { Singureni }^{380}\end{array}$ & $”$ \\
\hline 1252 & 1783 & ianuarie & 24 & $\begin{array}{l}\text { Cartea lui Alexandru Constantin <Mavrocordat> } \\
\text { voievod cu privire la moșia Bravicea }\end{array}$ & $"$ \\
\hline 1253 & 1810 & februarie & 22 & $\begin{array}{l}\text { Ravașul lui Roseti către serdari spre a ajuta pe } \\
\text { Constantin vameșul să-și scoată niște datorii }\end{array}$ & $"$ \\
\hline 1254 & 1808 & - & - & $\begin{array}{l}\text { Chitanțe cu diverse datorii ce are a lua Constantin } \\
\text { vameșul ( } 11 \text { bucăți) }\end{array}$ & $”$ \\
\hline 1255 & - & - & - & $\begin{array}{l}\text { Jalba lui Vasilie Nour către Divanul Moldovei cu } \\
\text { privire la o cîșlă cumpărată de la turci }\end{array}$ & $"$ \\
\hline 1256 & 1826 & iunie & 13 & $\begin{array}{l}\text { Înscrisul ce-și dau răzeșii din „Drăsliceni” pentru } \\
\text { strămutarea satului }\end{array}$ & $"$ \\
\hline 1257 & 1814 & septembrie & 10 & Cercetarea făcută hotarelor moșiei $<$ Pererita $>^{382}$ & $\#$ \\
\hline $\begin{array}{c}1257 \\
383\end{array}$ & 1814 & august & 14 & $\begin{array}{l}\text { Cererea Casandrei }<\text { comisoaia }>^{384} \text { cu privire la } \\
\text { hotarele moșiei }<\text { Pererita }>\end{array}$ & $"$ \\
\hline 1258 & 1811 & iulie & 27 & $\begin{array}{l}\text { Cererea Casandrei <comisoaia > cu privire la } \\
\text { hotarele moșiei < Pererita }>\end{array}$ & $"$ \\
\hline $\begin{array}{c}1258 \\
385\end{array}$ & 1809 & noiembrie & 18 & $\begin{array}{l}\text { Mărturia hotarnică a moșiei <Medeleni, partea din } \\
\text { stînga Prutului, în ținutul Iași > } 386\end{array}$ & $"$ \\
\hline 1259 & - & - & - & $\begin{array}{l}\text { Diverse chitanțe românești, evreiești, armenești, în } \\
13 \text { bucăți }\end{array}$ & $"$ \\
\hline 1260 & 1810 & mai & 23 & $\begin{array}{l}\text { Porunca Divanului Moldovei către „Neovdan” } \\
\text { pentru moșia Casandrei comisoaia }\end{array}$ & $"$ \\
\hline 1261 & 1818 & ianuarie & 11 & $\begin{array}{l}\text { Scrisoarea lui Alexandru <către Vasile V. Șafirov, la } \\
\text { Sculeni>, în pricina unor răzeși ce se judecă }{ }^{387}\end{array}$ & ” \\
\hline 1262 & $\frac{7249}{1741}$ & iulie & 8 & $\begin{array}{l}\text { Zapisul lui Ștefan Ciolac pentru o parte din moșia } \\
\text { Pocșăști }^{388}\end{array}$ & $"$ \\
\hline 1263 & 1810 & februarie & 15 & Contractul de arendare a cîrciumilor din Criuleni & ” \\
\hline 1264 & 1819 & - & - & Contractul de arendare a satului Criuleni & ” \\
\hline
\end{tabular}

\footnotetext{
${ }^{375}$ În text: „Morărescu”.

${ }^{376}$ Boga (1928b), p. 54, nr. LXVIII, cu data de zi: 29.

${ }^{377}$ Doc. T,. Mold., XII, p. 298, nr. 309.

${ }^{378}$ Probabil: „Sărbiceni”.

${ }^{379}$ Boga (1938a), p. 44-47, nr. XIX.

${ }^{380}$ MEF, VIII, p. 79-80, nr. 45.

${ }^{381}$ Boga (1931a), p. 65-67, nr. LII.

${ }^{382}$ În text: „Peserita”.

${ }^{383}$ Număr dublat.

${ }^{384}$ În text: „Cernișoaia”.

${ }^{385}$ Număr dublat.

${ }^{386}$ În text, greșit: „Podoleni”. Boga (1938a), p. 263-266, nr. LXXI.

${ }^{387}$ Boga (1928b), p. 41, nr. XLIX.

${ }^{388}$ MEF, VIII, p. 168, nr. 130.
} 


\begin{tabular}{|c|c|c|c|c|c|}
\hline 1265 & 1817 & aprilie & 5 & $\begin{array}{l}\text { Chitanțe pentru diverse sume semnate de „Sala” ( } 4 \\
\text { bucăți) }\end{array}$ & ” \\
\hline 1266 & 1817 & ” & " & Mărturia pentru hotarele Creulenilor & \# \\
\hline 1267 & 1819 & aprilie & 11 & Contract de arendare a Creulenilor & $\begin{array}{l}\text { românesc, cu trad. } \\
\text { rusească }\end{array}$ \\
\hline 1268 & - & - & - & 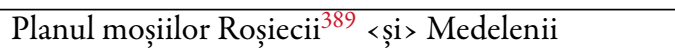 & românesc \\
\hline 1269 & $\frac{7241}{1733}$ & februarie & 18 & $\begin{array}{l}\text { Zapisul lui Moise }<\text { Vărzari }{ }^{390} \text { prin care vinde o } \\
\text { parte din Pocșești }{ }^{391}\end{array}$ & " \\
\hline 1270 & $\frac{7224}{1716}$ & februarie & 8 & Socoteala moșiilor rămase de la Nicolae Donici & copie \\
\hline 1271 & 1767 & februarie & 7 & $\begin{array}{l}\text { Cartea lui Grigorie Ghica voievod, dată lui lui } \\
\text { Darie Donici, pentru moșiile lui }\end{array}$ & românesc \\
\hline 1272 & 1766 & martie & 23 & $\begin{array}{l}\text { Zapisul lui Andrei Crucerescul pentru împărțeala } \\
\text { moșiilor Doniceștilor } 392\end{array}$ & ” \\
\hline 1273 & 1798 & mai & 31 & $\begin{array}{l}\text { Cartea lui Alexandru Calimah voievod pentru } \\
\text { moșia Puhoi a Crucereștilor }{ }^{393}\end{array}$ & ” \\
\hline 1274 & 1799 & decembrie & 4 & $\begin{array}{l}\text { Jalba lui Grigorie Crucerescul pentru moșia } \\
\text { Puhoiul }\end{array}$ & " \\
\hline 1275 & 1799 & noiembrie & 17 & Idem & ” \\
\hline 1276 & 1799 & noiembrie & 26 & $\begin{array}{l}\text { Cartea lui Constantin Ipsilanti voievod pentru } \\
\text { moșia Puhoiul }\end{array}$ & $"$ \\
\hline 1277 & 1826 & aprilie & 3 & Exoflisis între Iordache Alexandri și A. Burda & " \\
\hline 1278 & 1813 & august & 14 & $\begin{array}{l}\text { Zapis de vînzare a unei case din Chişinău a lui Ion } \\
\text { „Dinza” }\end{array}$ & " \\
\hline 1279 & 1812 & - & - & $\begin{array}{l}\text { Diverse recepise de primirea chiriei din partea lui } \\
\text { Mihai Butuc }\end{array}$ & $"$ \\
\hline 1280 & 1826 & - & - & $\begin{array}{l}\text { Diverse recepise de primirea unor bani, semnate de } \\
\text { Maria serdăreasa }\end{array}$ & " \\
\hline 1281 & 1804 & iunie & 30 & $\begin{array}{l}\text { Zapisul unor răzeși prin care vînd o parte din } \\
\text { Leușeni, <din ținutul Orhei }>394\end{array}$ & ” \\
\hline 1282 & 1818 & martie & 13 & $\begin{array}{l}\text { Zapisul unor răzeși prin care vînd o parte din } \\
\text { Ghermănești }\end{array}$ & " \\
\hline 1282 & 1824 & iunie & - & Polița de lei 1.000, semnată evreiește & ” \\
\hline 1284 & 1823 & februarie & 10 & $\begin{array}{l}\text { Contract de arendare a moției Zamcioji, în cinci } \\
\text { exemplare, pentru anii '24,'25, '26, '27'395. }\end{array}$ & " \\
\hline 1285 & 1823 & iulie & 10 & $\begin{array}{l}\text { Foaia de zestre a Ecaterinei pentru fata sa, } \\
<\text { Anghelușa }>396\end{array}$ & " \\
\hline 1286 & 1817 & ianuarie & 12 & $\begin{array}{l}\text { Jalba de la Enachi către Manolache pentru niște } \\
\text { vînzări }\end{array}$ & " \\
\hline 1287 & 1811 & martie & 2 & $\begin{array}{l}\text { Scrisoarea lui Enache < Matasă căpitan > către } \\
\text { Manolachi <Calmuțchi> pentru niște vînzărij }\end{array}$ & ” \\
\hline 1288 & 1812 & iunie & 2 & $\begin{array}{l}\text { Porunca Divanului Cnejiei Moldovei pentru } \\
\text { hotarele moșiei Milești }\end{array}$ & ” \\
\hline 1289 & 1853 & noiembrie & 7 & Planul satului Roșcani & $\begin{array}{l}<\text { românesc }>\text {, cu trad. } \\
\text { rusească }\end{array}$ \\
\hline 1290 & 1823 & mai & 4 & Planul moșiei Foltești & rusesc \\
\hline
\end{tabular}

\footnotetext{
${ }^{389}$ Probabil: „Roșietici”.

${ }^{390}$ În text: „Veităman”.

${ }^{391}$ MEF, VIII, p. 120-121, nr. 88.

${ }^{392}$ Doc. T. Mold., IX, p. 181-182, nr. 156.

${ }^{393}$ Doc. T. Mold., XI, p. 283-284, nr. 221.

${ }^{394}$ Doc. T. Mold., XII, p. 258-259, nr. 263.

${ }^{395}$ Data rezumatului este greșită: „1713”.

${ }^{396}$ În text, greșit: „Burghelușei” și data de lună (,iulie”). Boga (1928a), p. 18-20, nr. XI.

${ }^{397}$ Boga (1928b), p. 21, nr. XVIII.
} 


\begin{tabular}{|c|c|c|c|c|c|}
\hline 1291 & 1859 & noiembrie & 3 & Planul satului $<$ Tomazi ${ }^{398}$ și Cioburci & trad. rusească \\
\hline 1292 & 1859 & - & - & Planul gîrlei Modreanu & ” \\
\hline 1293 & - & - & - & $\begin{array}{l}\text { Izvod de diverse acte depuse la Judecătorie (15 } \\
\text { bucăți) }\end{array}$ & românesc \\
\hline 1294 & - & - & - & Diverse chitanțe de împrumuturi, în zece bucăți & ” \\
\hline 1295 & 1826 & noiembrie & 20 & Izvod de marfă ce s-a primit de la fabrică & ” \\
\hline 1296 & 1821 & iulie & 30 & Planul moşiilor Mamaligă, Căşla & ” \\
\hline 1297 & $\frac{7170}{1662}$ & iunie & 10 & $\begin{array}{l}\text { Suret după hotărîrea lui Miron Costin pîrcălabul de } \\
\text { Hotin, < pentru hotarul satului Giunești, din } \\
\text { ținutul Hotin }>399\end{array}$ & " \\
\hline 1298 & 1814 & august & 15 & $\begin{array}{l}\text { Copie după zapisul lui Păunel prin care vinde o } \\
\text { bucată de loc din Valeva }\end{array}$ & copie \\
\hline 1299 & 1814 & septembrie & 1 & $\begin{array}{l}\text { Zapisul lui Ion Chițescul prin care vinde o parte } \\
\text { din „Siniban” } 400\end{array}$ & ” \\
\hline 1300 & 1810 & Iunie & 13 & $\begin{array}{l}\text { Porunca Divanului Cnejiei Moldovei cu privire la } \\
\text { satul Malinții }\end{array}$ & ” \\
\hline 1301 & 1811 & ianuarie & 11 & Idem & ” \\
\hline 1302 & 1810 & ianuarie & 13 & Mărturia cu privire la satul Malinții & ” \\
\hline 1303 & $\frac{7161}{1652}$ & octombrie & 9 & $\begin{array}{l}\text { Copie după cartea lui Gheorghe Ștefan }<\text { mare } \\
\text { logofăt și a altor boieri }>\text { privitoare la }<\text { mai multe } \\
\text { sate }>401\end{array}$ & ” \\
\hline 1304 & 1773 & iunie & 10 & $\begin{array}{l}\text { Copie după izvodul moșiilor ce are Ioan Mitescul } \\
\text { în ținutul Hotinului }\end{array}$ & ” \\
\hline 1305 & - & - & - & Opise de diverse & ” \\
\hline 1306 & $\frac{7178}{1670}$ & august & 23 & $\begin{array}{l}\text { Cartea lui Duca voievod prin care face danie } \\
\text { mănăstirii Cetățuia din Iași satul Dăngeni }{ }^{402}\end{array}$ & " \\
\hline 1307 & 1818 & august & 15 & $\begin{array}{l}\text { Diata preotului Vasilie, <din satul Bălăurești>, prin } \\
\text { care își lasă averea moștenitorilor săi }{ }^{403}\end{array}$ & românesc \\
\hline 1308 & 1827 & iunie & 13 & $\begin{array}{l}\text { Foaie de zestre ce dă preoteasa Catrina fiului ei }<\text { de } \\
\text { suflet }>\text {, Toma, }<\text { fiul lui Toader Iuga }>404\end{array}$ & ” \\
\hline 1309 & 1827 & iunie & 8 & $\begin{array}{l}\text { Izvod de cheltuieli ce s-au făcut la îngroparea } \\
\text { preotului Vasilie }\end{array}$ & românesc \\
\hline 1310 & - & - & - & $\begin{array}{l}\text { Copie după zapisul lui Matei prin care vinde o parte } \\
\text { din moșia Durlești }\end{array}$ & ” \\
\hline 1311 & 1827 & iunie & 12 & $\begin{array}{l}\text { Mărturia răzeșilor din Volcineți pentru hotarele } \\
\text { moșiei }\end{array}$ & ” \\
\hline 1312 & 1801 & iulie & 14 & $\begin{array}{l}\text { Zapisul lui Trohim Florea pentru vînzarea unei } \\
\text { bucăți din <Nișcani, din ținutul Orhei〉 }\end{array}$ & ” \\
\hline 1313 & 1826 & august & 13 & Pașaportul lui Manolache Adam & $"$ \\
\hline 1314 & 1827 & martie & 11 & $\begin{array}{l}\text { Jalba lui Manolache Adam pentru o parte din } \\
\text { Colicăuți }\end{array}$ & " \\
\hline 1315 & 1810 & iunie & 22 & $\begin{array}{l}\text { Zapisul lui Lupu Crăciun pentru o parte din } \\
\text { Puțintei }\end{array}$ & $"$ \\
\hline 1316 & 1810 & ianuarie & 6 & $\begin{array}{l}\text { Zapisul lui Pavel Crăciun pentru o parte din } \\
\text { Puțintei }\end{array}$ & ” \\
\hline 1317 & 1821 & iulie & 9 & $\begin{array}{l}\text { Chitanțe (2) de primirea unor bani din partea lui } \\
\text { Pavel Crăciun }\end{array}$ & \\
\hline 1318 & 1827 & - & - & Mărturia dată lui Șmilcovici de rabinul Rabinovici & ” \\
\hline
\end{tabular}

\footnotetext{
${ }^{398}$ În text: „Tomazi”.

${ }^{399}$ Boga (1938a), p. 23-24, nr. VII; MEF, V, p. 74-76, nr. 24.

${ }^{400}$ Poate „Sinihău”.

${ }^{401}$ Rezumat cu greșeli: „,voievod”, „privitor la satul Sinecani”. Boga (1932a), p. 156, nr. XIX (marii boieri întăresc împărțeala moșiilor făcută de Tinta, fiica lui Miron din Sinehău).

${ }^{402}$ Boga (1930c), p. 169-170, nr. XXXIII; MEF, V, p. 295-297, nr. 126.

${ }^{403}$ Boga (1929a), p. 25-36, nr. XXVI.

${ }^{404}$ Boga (1928a), p. 45-46, nr. XXX.
} 


\begin{tabular}{|c|c|c|c|c|c|}
\hline 1319 & 1814 & aprilie & 29 & $\begin{array}{l}\text { Zapisul lui Vicol, dat surorii sale, pentru partea ce i } \\
\text { se cuvine < dintr-o moșie, după moartea lui }{ }^{405}\end{array}$ & $"$ \\
\hline 1320 & 1828 & august & 5 & Zapisul lui Vasilie Munteanu prin care vinde o vie & ” \\
\hline 1321 & 1826 & august & 30 & Adeverința lui Vicol, ce o dă surorii sale & ” \\
\hline 1322 & 1830 & februarie & - & $\begin{array}{l}\text { Chitanțe (6) iscălite de Popa pentru bani, în } \\
\text { jumătăți }\end{array}$ & " \\
\hline 1323 & 1814 & iunie & 12 & Planul satului Horbinești, $<$ din ținutul Orhei $>^{406}$ & ” \\
\hline 1325 & $\frac{7280}{1772}$ & iulie & 5 & $\begin{array}{l}\text { Raportul boierilor privitor la hotărnicirea moșiei } \\
\text { Sferja }\end{array}$ & " \\
\hline 1326 & 1809 & mai & 30 & $\begin{array}{l}\text { Zapisul lui Grigorie Stratan pentru o parte din } \\
\text { moșia Nişcani }\end{array}$ & " \\
\hline 1327 & $\frac{7240}{1732}$ & iulie & 5 & $\begin{array}{l}\text { Raportul lui Donici serdar pentru hotarele moșiei } \\
\text { Sferja }\end{array}$ & ” \\
\hline 1328 & 1809 & mai & 30 & $\begin{array}{l}\text { Zapisul lui Ion Stratan pentru o parte din moșia } \\
\text { Nişcani }\end{array}$ & $"$ \\
\hline 1329 & 1821 & octombrie & 20 & $\begin{array}{l}\text { Protestul lui Vasilie Frunză în pricina moșiei } \\
\text { Nișcani }\end{array}$ & " \\
\hline 1330 & 1782 & ianuarie & 15 & $\begin{array}{l}\text { Copie după zapisul lui Grigore Nicolaescul pentru } \\
\text { o parte din Milești }\end{array}$ & $"$ \\
\hline 1331 & 1786 & iunie & 30 & Hotarnica moșiei Milești, <din ținutul Iași ${ }^{407}$ & ” \\
\hline 1332 & 1811 & mai & 26 & $\begin{array}{l}\text { Zapisul lui Vasilie Popescu pentru o parte din } \\
\text { Milești }\end{array}$ & $"$ \\
\hline 1333 & 1825 & mai & 2 & $\begin{array}{l}\text { Mărturia „Erdani Gominova” pentru schimbul } \\
\text { făcut la Milești }\end{array}$ & " \\
\hline 1334 & 1786 & iunie & 18 & Zapisul lui Vasilie Caisin pentru o parte din Milești & $”$ \\
\hline 1335 & 1779 & septembrie & 5 & $\begin{array}{l}\text { Zapisul lui Andrei „Dotea” pentru nişte datorii ce } \\
\text { are a da lui Ioniță }\end{array}$ & românesc \\
\hline 1336 & 1807 & ianuarie & 31 & Jalba lui Ștefan Maiculescu & $"$ \\
\hline 1337 & 1824 & mai & 18 & $\begin{array}{l}\text { Zapisul lui Toader „Dotca” pentru o parte din } \\
\text { moșia <Gălești > } 408\end{array}$ & $"$ \\
\hline 1338 & 1800 & februarie & 9 & $\begin{array}{l}\text { Vechilimeaua dată de mai mulți răzeși lui D. Jerdan } \\
\text { spre a le căuta moșiile }\end{array}$ & $"$ \\
\hline 1339 & 1804 & februarie & 24 & $\begin{array}{l}\text { Zapisul Varvarei prin care vinde o parte din } \\
\text { Rădeni }{ }^{409}\end{array}$ & " \\
\hline 1340 & 1827 & aprilie & 27 & Zapisul de vinzare a unor case de Andrei Popa & $”$ \\
\hline 1341 & 1821 & ianuarie & 14 & $\begin{array}{l}\text { Vechilime dată de răzeșii din Dealul Înalt lui Ioniță } \\
\text { Carmil }\end{array}$ & $"$ \\
\hline 1342 & 1786 & Iulie & 13 & $\begin{array}{l}\text { Jalba răzeșilor din Bravicea către domn pentru } \\
\text { moșie }\end{array}$ & $"$ \\
\hline 1343 & $\begin{array}{l}1819- \\
20\end{array}$ & - & - & $\begin{array}{l}\text { Diverse chitanțe semnate de boierii din Chișinău } \\
\text { prin care se îndatorau a plăti mărfurile și cărțile } \\
\text { furnizate de la magazinul lui Tănase Ganii din } \\
\text { Chișinău }\end{array}$ & $\begin{array}{l}\text { românește } \\
\text { grecește } \\
\text { evreiește } \\
\text { nemțește }\end{array}$ \\
\hline 1344 & 1805 & februarie & 5 & $\begin{array}{l}\text { Zapisul lui Simion }<\text { Arnăutul }{ }^{410} \text { prin care vinde o } \\
\text { arătură } 411\end{array}$ & românesc \\
\hline 1345 & 1804 & septembrie & 1 & $\begin{array}{l}\text { Zapisul lui Simion }<\text { Arnăutul }>\text { prin care vinde o } \\
\text { jumătate de vie }{ }^{412}\end{array}$ & $”$ \\
\hline
\end{tabular}

\footnotetext{
${ }^{405}$ Boga (1929a), p. 31, nr. XXII. 286-291, nr. LXXV (12 iunie 1814).

${ }^{408}$ În text: „Gailești”.

${ }^{409}$ Doc. T. Mold., XII, p. 232-233, nr. 235.

${ }^{410}$ În text: „Omătul”.

${ }^{411}$ Doc. T..Mold., XII, p. 287-288, nr. 301.

${ }^{412}$ Doc. T. Mold., XII, p. 268, nr. 277.
}

${ }^{406}$ Dacă sub numele „plan”, arhivistul a înțeles mărturie hotarnică, atunci documentul este cel publicat de Boga (1938a), p.

${ }^{407}$ Boga (1938a), p. 118-121, nr. XLII; Doc. T,.Mold., X, p. 223-225, nr. 176. 


\begin{tabular}{|c|c|c|c|c|c|}
\hline 1346 & 1814 & iulie & 30 & Zapis de împrumutare a 2.215 lei a lui Costanțiu & " \\
\hline 1347 & 1818 & martie & 4 & $\begin{array}{l}\text { Zapisul lui Gheorghe Nistreanul prin care vinde o } \\
\text { parte din Milești }\end{array}$ & " \\
\hline 1348 & 1818 & februarie & 18 & $\begin{array}{l}\text { Zapisul Anastasiei Stănculeasa prin care vinde o } \\
\text { casă }\end{array}$ & $"$ \\
\hline 1349 & 1807 & septembrie & 17 & $\begin{array}{l}\text { Porunca Isprăvniciei pentru hotarele moșiei } \\
\text { „Salinești” } 413\end{array}$ & $"$ \\
\hline 1350 & 1852 & iunie & 5 & $\begin{array}{l}\text { Raportul lui Constantin Iancul pentru hotarele } \\
\text { moșiei Vărzărești }\end{array}$ & 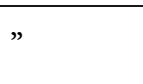 \\
\hline 1351 & 1813 & noiembrie & 21 & $\begin{array}{l}\text { Raportul răzessilor pentru hotarele moșiei } \\
<\text { Vărzărești }>114\end{array}$ & $"$ \\
\hline 1352 & 1813 & aprilie & 24 & $\begin{array}{l}\text { Porunca Isprăvniciei pentru hotarele <moșiei } \\
\text { Vărzărești> }\end{array}$ & $"$ \\
\hline 1353 & 1855 & martie & 14 & $\begin{array}{l}\text { Mărturia lui Toader Robul cu privire la moșia } \\
\text { Vărzărești }\end{array}$ & 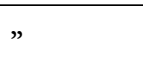 \\
\hline 1354 & 1819 & aprilie & 14 & Scrisoare către Cazimir în pricina unor bani & ” \\
\hline 1355 & 1819 & mai & 4 & Act de învoială între frații Druhuești & ” \\
\hline 1356 & 1785 & iunie & 30 & Zapisul lui Nastasie pentru o parte din Cobusca ${ }^{415}$ & ” \\
\hline 1357 & 1776 & iunie & 10 & $\begin{array}{l}\text { Copie după zapisul locuitorilor din Bodești privitor } \\
\text { la frații Varticești }\end{array}$ & " \\
\hline 1358 & 1807 & februarie & 3 & Porunca Logofeției Mari către Sărdăria de Orheiu & \# \\
\hline 1359 & 1788 & mai & 17 & Zapisul lui Andrei Dănuță pentru moșia Cobusca & ” \\
\hline 1360 & 1806 & septembrie & 28 & Zapisul lui Arsenie Opincă pentru bătrînul Opincă & românesc \\
\hline 1361 & 1825 & martie & 10 & Actul de învoială pentru arendarea moşiei Ivancea & " \\
\hline 1362 & 1820 & februarie & 18 & Polița lui Ușacov & " \\
\hline 1363 & 1819 & mai & 17 & Actul de împărțeală a moșiei Trifeni & ” \\
\hline 1364 & 1813 & martie & 19 & $\begin{array}{l}\text { Chitanța lui „Slioma” pentru } 100 \text { galbeni olandezi } \\
\text { (4 exemplare) }\end{array}$ & $"$ \\
\hline 1365 & 1814 & aprilie & 14 & $\begin{array}{l}\text { Chitanța lui Ioan Cheșcu, pentru } 10.000 \text { lei, și alte } \\
\text { cinci cu diverse sume }\end{array}$ & " \\
\hline 1366 & 1824 & aprilie & 29 & $\begin{array}{l}\text { Scrisoarea lui Stratonic ieromonah pentru niște } \\
\text { bani } 416\end{array}$ & " \\
\hline 1367 & 1815 & februarie & 15 & $\begin{array}{l}\text { Hotărîrea Departamentului 1-iu în pricina lui } \\
\text { Enacache Păun și a răzeșilor din Cojuşna }\end{array}$ & $"$ \\
\hline 1368 & 1814 & iunie & 22 & $\begin{array}{l}\text { Schimbul făcut între Enacache Păun și răzeșii din } \\
\text { Cojușna }\end{array}$ & $"$ \\
\hline 1369 & 1812 & august & 20 & Izvod de măsurile moșiei Cojuşna & 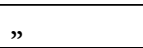 \\
\hline 1370 & 1808 & martie & 16 & Învoiala între Păun și Damaschin din Cojușna & ” \\
\hline 1371 & 1819 & ianuarie & 28 & Zapisul lui Danilă Grigoraș pentru moşia Stolniceni & $\#$ \\
\hline 1372 & $\frac{7175}{1667}$ & noiembrie & 28 & $\begin{array}{l}\text { Raportul boierilor pentru hotarele moșiei } \\
\text { Stolniceni, < <in ținutul Lăpușna }>417\end{array}$ & ” \\
\hline 1373 & 1827 & octombrie & 9 & Porunca Isprăvniciei Orheiu către ocolaşi & ” \\
\hline 1374 & 1819 & mai & 22 & $\begin{array}{l}\text { Zapisul lui Mihail Cherdivară pentru } 4 \text { stînjeni din } \\
\text { moșia Stolniceni }\end{array}$ & $"$ \\
\hline 1375 & 1819 & iunie & 14 & Zapisul răzeșilor din Ciuciuleni & " \\
\hline 1376 & 1827 & aprilie & 14 & $\begin{array}{l}\text { Danie pentru mănăstirea Xiropotam }{ }^{418}<\text { de la } \\
\text { Muntele Athos }>\end{array}$ & $"$ \\
\hline 1377 & - & - & - & Scrisoarea lui Anghel pentru niște chestiuni bănești & ” \\
\hline
\end{tabular}

\footnotetext{
${ }^{413}$ Poate „Stănilești”.

${ }^{414}$ Aici, și în rezumatul următor: „Volcănești”.

${ }^{415}$ Doc. T,.Mold., X, p. 196, nr. 149 (cu data de zi: „20”).

${ }^{416}$ Boga (1928b), p. 98, nr. CXXVIII.

${ }^{417}$ Boga (1938a), p. 25-26, nr. VIII.

${ }^{418}$ In text: „Kiropotan”.
} 


\begin{tabular}{|c|c|c|c|c|c|}
\hline $\begin{array}{c}1377 \\
419\end{array}$ & 1826 & - & - & $\begin{array}{l}\text { Chitanțe diferite iscălite de chiriași, în număr de } \\
\text { treizeci cinci (35) }\end{array}$ & grecești \\
\hline 1378 & 1830 & iunie & 2 & $\begin{array}{l}\text { Copie după hotărîrea Adunării nobililor în chestia } \\
\text { spătarului Feodosie }\end{array}$ & rusesc \\
\hline 1379 & 1825 & februarie & 12 & $\begin{array}{l}\text { Traducerea după învoiala între Hristodulo cu } \\
\text { egumenul mănăstirii <închinate> }\end{array}$ & ” \\
\hline 1380 & 1830 & februarie & 12 & Cererea lui Chiriazi pentru moșia Leușeni & 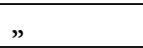 \\
\hline 1381 & 1832 & februarie & 20 & $\begin{array}{l}\text { Copie după cartea lui Mihai Suțu voievod dată lui } \\
\text { Hristodulo }\end{array}$ & $"$ \\
\hline 1383 & 1819 & - & - & Planul satului Caracușeni & 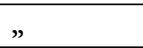 \\
\hline 1384 & - & - & - & Planul satului Talmaz & ” \\
\hline 1385 & 1826 & septembrie & 30 & $\begin{array}{l}\text { Hotărîrea Obșteștii Adunări în pricina lui } \\
\text { Zamfirachi Rali }\end{array}$ & " \\
\hline 1386 & 1784 & iunie & 25 & $\begin{array}{l}\text { Hotărîrea Divanului Moldovei pentru moșia } \\
\text { Lencăuții }\end{array}$ & ” \\
\hline 1387 & 1811 & iunie & 29 & $\begin{array}{l}\text { Divanul Cnejiei Moldovei pentru moşiile } \\
\text { mănăstirii Cetățuia }\end{array}$ & $”$ \\
\hline 1388 & $\frac{7181}{1673}$ & iunie & 5 & $\begin{array}{l}\text { Cartea lui Ștefan Petriceico voievod dată mănăstirii } \\
\text { Cetățuia }^{421}\end{array}$ & rusesc \\
\hline 1389 & $\frac{7181}{1673}$ & februarie & 28 & $\begin{array}{l}\text { Cartea lui Stefan Petriceico voievod dată } \\
\text { pîrcălabilor de Hotin } \\
422\end{array}$ & ” \\
\hline 1390 & $\frac{7237}{1729}$ & aprilie & 27 & $\begin{array}{l}\text { Cartea lui Grigore Ghica voievod dată egumenului } \\
\text { mănăstirii Cetățuia }{ }^{423}\end{array}$ & $"$ \\
\hline 1391 & 1806 & ianuarie & 30 & Spița unor răzeși din Nisporeni & românesc \\
\hline 1392 & $\frac{7110}{1602}$ & - & - & $\begin{array}{l}\text { Cartea lui Eremia Movilă voievod, dată lui Gavril, } \\
\text { pentru satul Popești }{ }^{424}\end{array}$ & " \\
\hline 1393 & 1825 & iunie & 30 & $\begin{array}{l}\text { Povestca către răzești din moșia „Polinești” }{ }^{25} \\
\text { pentru hotar }\end{array}$ & $”$ \\
\hline 1394 & 1810 & mai & 26 & $\begin{array}{l}\text { Cartea Divanului dată lui Sandu „Haidinul” pentru } \\
\text { o parte din Nisporeni }\end{array}$ & ” \\
\hline 1395 & 1797 & februarie & 10 & $\begin{array}{l}\text { Cartea lui Alexandru Calimah voievod pentru } \\
\text { moșia Horbinești }\end{array}$ & $”$ \\
\hline 1396 & 1818 & ianuarie & 11 & $\begin{array}{l}\text { Jalba fraților Hajdău prin care arată învoiala } \\
\text { intervenită între ei }\end{array}$ & $"$ \\
\hline 1397 & 1823 & februarie & 21 & $\begin{array}{l}\text { Vechilimeaua dată de Toader Hajdău lui Simion } \\
\text { Novodvorschi }\end{array}$ & ” \\
\hline 1398 & 1817 & martie & 17 & Învoiala între frații Hajdău & ” \\
\hline 1399 & 1806 & august & - & $\begin{array}{l}\text { Cartea lui Alexandru Moruzi voievod dată lui } \\
\text { Manolache Donici }\end{array}$ & " \\
\hline 1400 & 1807 & februarie & 27 & Porunca Divanului pentru moșia Peresecina & ” \\
\hline 1401 & 1807 & iunie & 24 & $\begin{array}{l}\text { Carte de judecată a Divanului pentru răzeșii din } \\
\text { Peresecina }\end{array}$ & " \\
\hline 1402 & 1826 & octombrie & 21 & $\begin{array}{l}\text { Scrisoare către Manolache pentru niște scrisori de } \\
\text { judecată }\end{array}$ & rusesc \\
\hline 1403 & 1814 & iulie & - & $\begin{array}{l}\text { Mărturia pîrcălabului Hotinului pentru moșia } \\
\text { „Bălășești” }\end{array}$ & ” \\
\hline
\end{tabular}

\footnotetext{
${ }^{419}$ Număr dublat.

${ }^{420}$ În text: ,închiriate”.

${ }^{421}$ MEF, VI, p. 91-93, nr. 24 (cu data de lună: „iulie”).

${ }^{422} \mathrm{MEF}, \mathrm{VI}$, p. $84-85$, nr. 20.

${ }^{423}$ Boga (1930a), p. 359, nr. XV (cu data corectă: $1728<7236>$ aprilie 26). În acest opis, data a fost citită greșit din cauza confuziei între slovo-cifrele: 6 și 7.

${ }^{424}$ Boga (1929f), p. 75-76, nr. III (cu data: „11 iulie $1602<7210>$ ); MEF, I, p. 182-184, nr. 78.

${ }^{425}$ Greșit. Poate „Popești”.

${ }^{426}$ Greșit. Poate „Balasinești”.
} 


\begin{tabular}{|c|c|c|c|c|c|}
\hline 1404 & $<1679>$ & august & 8 & $\begin{array}{l}\text { Zapisul < sulgerului }>{ }^{427} \text { Jora pentru satul Rujavinți, } \\
<\text { din ținutul Hotin }>{ }^{428}\end{array}$ & $"$ \\
\hline 1405 & $\frac{7125}{1616}$ & octombrie & 12 & $\begin{array}{l}\text { Cartea lui Radul voievod dată lui Golia pentru } \\
\text { Măscăuții29 }\end{array}$ & $"$ \\
\hline 1406 & 1825 & mai & 30 & Nota cancelariei Judecătoriei cu privire la niște acte & ” \\
\hline 1407 & 1814 & - & - & $\begin{array}{l}\text { Copie după hotărîrea în pricina împresurării moşiei } \\
\text { „Presița” }\end{array}$ & " \\
\hline 1408 & 1827 & februarie & 9 & $\begin{array}{l}\text { Cererea Judecătoriei ținutului privitoare la niște } \\
\text { acte }\end{array}$ & $"$ \\
\hline 1409 & 1784 & decembrie & 28 & Zapisul lui Ignat pentru moșia Milești ${ }^{430}$ & " \\
\hline 1410 & 1783 & martie & 11 & Zapisul lui Crăciun pentru moșia Hărtopeni & $"$ \\
\hline 1411 & 1785 & ianuarie & 27 & Zapisul lui Ion Miron pentru moșia Milești ${ }^{431}$ & " \\
\hline 1412 & 1816 & martie & 14 & Spița neamurilor moșiei Milești & ” \\
\hline 1413 & 1792 & noiembrie & 24 & $\begin{array}{l}\text { Zapisul lui Grigoraș Iordan pentru moşia } \\
\text { „Gazilova” }\end{array}$ & " \\
\hline 1414 & 1813 & aprilie & 20 & $\begin{array}{l}\text { Cercetarea ocolaşului de Braniște pentru moșia } \\
\text { Șendreni }\end{array}$ & " \\
\hline 1415 & 1808 & septembrie & 18 & Porunca Sărdăriei Orheiu pentru moșia Tăbărești & Rusesc \\
\hline 1416 & 1819 & iulie & 15 & Hotărîrea Judecătoriei în chestia moșiei Horodiștea & 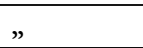 \\
\hline 1417 & 1825 & august & 11 & Izvod de documentele infățișate de Grigoraș Batărul & " \\
\hline 1418 & 1849 & aprilie & 9 & Actul de arendare a moșiei „Porujeni” & ” \\
\hline 1419 & 1845 & octombrie & 28 & $\begin{array}{l}\text { Scrisoarea lui < Iordachi > Rusu, < din Rădeni >, către } \\
<\text { Anfim > Leontovici < Jucovschi, la Macăreuca >, } \\
\text { prin care îi cere niște datorii }{ }^{432}\end{array}$ & " \\
\hline 1420 & 1847 & octombrie & 28 & $\begin{array}{l}\text { Scrisoarea lui < Iordachi> Rusu către <Anfim> } \\
\text { Leontovici <Jucovschi> prin care îi cere niște } \\
\text { datorii }^{433}\end{array}$ & \\
\hline 1421 & 1822 & iunie & 15 & $\begin{array}{l}\text { Mărturia lui Măcărescu privitor la pagubele avute } \\
\text { de Gh. Costandache }\end{array}$ & $"$ \\
\hline 1422 & 1784 & iunie & 24 & $\begin{array}{l}\text { Mărturia răzeșilor Furdui și alții pentru hotarele } \\
\text { moșiei lui „Hul. Desculțul” }\end{array}$ & ” \\
\hline 1423 & 1815 & iulie & 8 & $\begin{array}{l}\text { Mărturia răzeșilor din Dănceni <privitoare la > } \\
\text { hotarele moșiei Bostanca }\end{array}$ & ” \\
\hline 1434 & 1813 & - & - & Planul moșiei Bostanca & 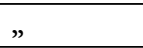 \\
\hline 1435 & 1822 & mai & 24 & Socoteala între Gh. Costandache și Măcărescu & românesc \\
\hline 1436 & 1820 & octombrie & 13 & $\begin{array}{l}\text { Raportul Divanului Moldovei către domn privitor } \\
\text { la averea răposatului Nicolae Stratulat }\end{array}$ & $"$ \\
\hline 1437 & 1758 & maiu & 12 & $\begin{array}{l}\text { Mărturia lui Grigoraș Hodorogea pentru moşia } \\
\text { Braviceni }\end{array}$ & " \\
\hline 1438 & 1817 & aprilie & 12 & Porunca Sărdăriei Orheiu către ocolașii Câmpului & ” \\
\hline 1439 & 1809 & decembrie & 14 & $\begin{array}{l}\text { Declarația lui Andrei Feodosiu privitoare la } \\
\text { zăloagele sale }\end{array}$ & $"$ \\
\hline 1440 & 1817 & februarie & 27 & $\begin{array}{l}\text { Declarația lui Sandu Feodosiu privitoare la } \\
\text { zăloagele sale }\end{array}$ & ” \\
\hline
\end{tabular}

427 În text greșit: „serbilor”.

${ }^{428}$ Rezumatul are data greșită: „25 ianuarie 1815”. Boga (1929a), p. 6, nr. II (cu data: 8 august 1679). Constantinov (2014), p. 213, nota 9 (text după actul de la ANB, $A N$, XCI-65; actul a fost considerat, cu dovezi, de Tadeu Hașdeu, într-un proces din 1820 , „un adevărat plastograf”, la care editorul aduce noi argumente). Acest articol a fost republicat în 2017, însă sub un alt titlu, adăugîndu-i-se cîteva documente în plus (fără a fi comentate); vezi Constantinov \& Ciobanu (2017).

${ }^{429}$ MEF, I, p. 297-302, nr. 134.

${ }^{430}$ Doc. T.Mold., X, p. 188, nr. 140.

${ }^{431}$ Doc. T.Mold., X, p. 190-191, nr. 142 (cu data de zi: „25”).

${ }^{432}$ Boga (1928b), p. 142, nr. CXCV.

${ }^{433}$ Boga (1928b), p. 143-144, nr. CXCVII.

${ }^{434}$ Doc. T,. Mold., X, p. $172-173$, nr. 129. 


\begin{tabular}{|c|c|c|c|c|c|}
\hline 1441 & 1824 & februarie & 15 & Povesca Isprăvniciei Orheiu către $<$ Dinu $>{ }^{435}$ Rusul & \# \\
\hline 1442 & $\begin{array}{l}<1832> \\
436\end{array}$ & mai & 17 & $\begin{array}{l}\text { Adeverința lui Manolache Tarian pentru primirea } \\
\text { unor zapise }\end{array}$ & $"$ \\
\hline 1443 & 1826 & noiembrie & 30 & $\begin{array}{l}\text { Răspunsul cancelariei Judecătoriei <politicești> a } \\
\text { Basarabiei privitor la domeniul moșiilor Zămbreni } \\
\text { și Onutul }\end{array}$ & " \\
\hline 1444 & 1826 & ” & 6 & $\begin{array}{l}\text { Diverse izvoade de scrisorile ce s-au înfățişat pentru } \\
\text { moșia Ciocana ( } 5 \text { piese). }\end{array}$ & " \\
\hline 1445 & 1819 & septembrie & 27 & $\begin{array}{l}\text { Diverse chitanțe de sumele împrumutate de Panait } \\
\text { Cazimir ( } 2 \text { piese) }\end{array}$ & " \\
\hline 1446 & 1819 & septembrie & 9 & $\begin{array}{l}\text { Contractul de arendare a moșiilor Doljoc şi } \\
\text { Dolineni, proprietatea lui Panait Cazimir }\end{array}$ & ” \\
\hline 1447 & 1820 & aprilie & 17 & $\begin{array}{l}\text { Scrisoarea lui P. Cazimir către sătenii din Doljoc și } \\
\text { Dolineni prin care le face cunoscut că le-a arendat } \\
\text { pe } 2 \text { ani }\end{array}$ & $"$ \\
\hline 1448 & 1777 & februarie & 1 & $\begin{array}{l}\text { Copie după zapisul răzeșilor din Bălăneasa pentru } \\
\text { niște părți ale lor }{ }^{437}\end{array}$ & " \\
\hline 1449 & 1776 & ianuarie & 27 & $\begin{array}{l}\text { Zapisul mai multor răzeși prin care își vînd părțile } \\
\text { lor din Chivirești și Veisăști, < din ținutul } \\
\text { Lăpușna > } 438\end{array}$ & ” \\
\hline 1450 & 1825 & ianuarie & 14 & $\begin{array}{l}\text { Actul de vînzare al moșiei Bularda, proprietatea lui } \\
\text { Ioan Sturdza }\end{array}$ & ” \\
\hline 1451 & 1815 & noiembrie & 12 & $\begin{array}{l}\text { Referatul citorva boieri privitor la hotarele moșiei } \\
\text { lui Ioan Sturdza }\end{array}$ & ” \\
\hline 1452 & 1815 & noiembrie & 12 & $\begin{array}{l}\text { Spiță de neam a unor răzeși de la Dereneu, <din } \\
\text { ținutul Orhei> }\end{array}$ & ” \\
\hline 1453 & 1822 & mai & 26 & $\begin{array}{l}\text { Părțile ce s-au ales din Flămânzeni, proprietate lui } \\
\text { Sturza }\end{array}$ & ” \\
\hline 1454 & 1803 & iunie & 1 & $\begin{array}{l}\text { Cartea lui Constantin Moruzi voievod pentru } \\
\text { hotarele moșiei Bularda }{ }^{439}\end{array}$ & " \\
\hline 1455 & 1800 & decembrie & 28 & Hotarnica moșiei Bularda, $<$ din ținutul Orhei ${ }^{440}$ & ” \\
\hline 1456 & 1824 & ianuarie & 17 & $\begin{array}{l}\text { Hotărîrea Judecătoriei < politicești> a oblastiei } \\
\text { Basarabia pentru veniturile moșiei Costești }\end{array}$ & " \\
\hline 1457 & 1829 & iunie & 1 & $\begin{array}{l}\text { Zapisul lui Mereacre pentru datoria ce o are pentru } \\
\text { bătrînul Baicul }\end{array}$ & ” \\
\hline 1458 & 1829 & noiembrie & 18 & $\begin{array}{l}\text { Zapisul lui Vasilie Panfil pentru o parte din } \\
\text { Ciuciuleni }\end{array}$ & ” \\
\hline 1459 & 1831 & mai & 30 & $\begin{array}{l}\text { Zapisul răzeșilor Bivolești pentru o parte din } \\
\text { Costești }\end{array}$ & $"$ \\
\hline 1460 & 1829 & iunie & 12 & Zapisul lui Mereacre pentru o parte din Costesti & \# \\
\hline 1461 & 1827 & ianuarie & 2 & $\begin{array}{l}\text { Zapisul răzeșilor din Costești pentru niște părți de } \\
\text { moșie ale lor din Costești }\end{array}$ & 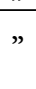 \\
\hline 1462 & 1805 & ianuarie & 25 & $\begin{array}{l}\text { Copie după cartea de judecată a Divanului pentru } \\
\text { moșia Căbăești }\end{array}$ & " \\
\hline 1463 & 1805 & ianuarie & 20 & $\begin{array}{l}\text { Copie după cartea de judecată a Divanului pentru } \\
\text { moșia Căbăești }\end{array}$ & 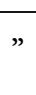 \\
\hline 1464 & 1804 & noiembrie & 11 & $\begin{array}{l}\text { Jalba către domn a lui Ion Crucerescu pentru moșia } \\
\text { Căbăești }\end{array}$ & $"$ \\
\hline 1465 & 1801 & decembrie & 16 & $\begin{array}{l}\text { Învoiala între Maria serdăreasa și Enache } \\
\text { Cantacuzino pentru hotărîrea moșiei Puhoi }\end{array}$ & $”$ \\
\hline
\end{tabular}

\footnotetext{
435 În text: „d-l”.

${ }^{436}$ În text, data greșită: „1532”.

${ }^{437}$ Doc. T. Mold., X, p. 57-58, nr. 38.

${ }^{438}$ Doc. T.Mold., X, p. 56-57, nr. 37, cu data: „26 ianuarie 1777”.

${ }^{439}$ Doc. T..Mold., XII, p. 175-176, nr. 162.

${ }^{440}$ Boga (1938a), p. 207-217, nr. LIX; Doc. T.. Mold., XI, p. 363-372, nr. 290.
} 


\begin{tabular}{|c|c|c|c|c|c|}
\hline 1465 & 1801 & decembrie & 13 & $\begin{array}{l}\text { Cartea lui Alexandru Suțu voievod pentru judecata } \\
\text { ce o au răzeșii din Căbăești }{ }^{441}\end{array}$ & $"$ \\
\hline 1466 & 1801 & noiembrie & 23 & $\begin{array}{l}\text { Jalba lui Grigorie Crucerescu către domn pentru } \\
\text { satele: Isacova, Onișcani, }\langle\text { Voinova }\rangle\langle 42\end{array}$ & $"$ \\
\hline 1467 & 1801 & septembrie & 4 & $\begin{array}{l}\text { Jalba lui Grigorie Crucerescu către domn pentru } \\
\text { moșia Puhoiul }\end{array}$ & ” \\
\hline 1468 & 1777 & iunie & 11 & Zapisul lui Palade pentru moșia Brădeni & ” \\
\hline 1469 & 1780 & octombrie & 6 & Hotarnica moșiei Brădeni, < din ținutul Iași ${ }^{443}$ & 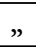 \\
\hline 1470 & 1780 & noiembrie & 21 & $\begin{array}{l}\text { Cartea lui Constantin Moruzi voievod pentru } \\
\text { moșia Măgurele, <ținutul Iași > } 444\end{array}$ & ” \\
\hline 1471 & 1780 & martie & 13 & Zapisul Paraschivei Ivașcu pentru moșia Brădeni & ” \\
\hline 1472 & 1781 & martie & 27 & Zapisul lui Vasile Razul pentru moșia Măgurele ${ }^{445}$ & ” \\
\hline 1473 & 1781 & mai & 14 & $\begin{array}{l}\text { Zapisul lui Constantin Bărgan pentru moșia } \\
\text { Măgura }\end{array}$ & $"$ \\
\hline 1474 & 1781 & mai & 19 & Zapisul lui Samson pentru moșia Brădeni ${ }^{447}$ & 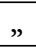 \\
\hline 1475 & 1789 & septembrie & 10 & Cartea Divanului pentru moșia Măgura & ” \\
\hline 1476 & 1783 & iunie & 17 & $\begin{array}{l}\text { Cartea lui Alexandru Constantin <Mavrocordat> } \\
\text { voievod pentru hotarele moșiilor Măgurelele, } \\
\text { <Brădeni și Nebojița, din ținutul Iași, stăpînite de } \\
\text { Mitropolia Moldovei }>448\end{array}$ & $"$ \\
\hline 1477 & 1781 & mai & 28 & Zapisul lui „Hancsu” Bărgan p. moșia Brădeni ${ }^{449}$ & $\#$ \\
\hline 1478 & 1777 & martie & 11 & Zapisul lui Arsenie Bărgan pentru moșia Brădeni & " \\
\hline 1478 & 1791 & iulie & 1 & $\begin{array}{l}\text { Cartea lui Alexandru Calimah voievod pentru } \\
\text { moșia Brădeni }\end{array}$ & $"$ \\
\hline 1479 & 1791 & noiembrie & 18 & $\begin{array}{l}\text { Copia după cartea lui Ambrosie arhiepiscop pentru } \\
\text { o parte din moșia Măgura }\end{array}$ & $”$ \\
\hline 1480 & 1690 & august & 15 & Zapisul răzeșilor pentru moșia Brădeni & 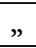 \\
\hline 1481 & 1766 & august & 6 & $\begin{array}{l}\text { Cartea lui Grigorie Calimah pentru moșia } \\
\text { Măgureni }\end{array}$ & $"$ \\
\hline 1482 & 1780 & aprilie & 9 & $\begin{array}{l}\text { Mărturia hotarnică pentru moșia Măgurele, <din } \\
\text { ținutul Iași }>450\end{array}$ & $"$ \\
\hline $\begin{array}{c}1482 \\
451\end{array}$ & 1798 & octombrie & 20 & Porunca Isprăvniciei pentru moșia „Bogheni” & $"$ \\
\hline 1483 & 1806 & ianuarie & 27 & $\begin{array}{l}\text { Alexandru <Constantin > Moruzi voievod pentru } \\
\text { moșia Măgurelele, <ținutul Iași }>{ }^{452}\end{array}$ & ” \\
\hline $\begin{array}{c}1483 \\
453\end{array}$ & 1806 & martie & 25 & Hotarnica moșiei <Măgurelele, din ținutul Iași ${ }^{454}$ & $"$ \\
\hline 1484 & 1809 & aprilie & 24 & Jalba lui Maftei căpitan pentru moșie & $\#$ \\
\hline 1485 & 1825 & iunie & 21 & Răspunsul lui A. Scorțescu pentru $<\ldots . .>^{455}$ & " \\
\hline 1486 & 1813 & decembrie & 27 & Zapisul lui Neculae pentru moșia Calimănești & ” \\
\hline
\end{tabular}

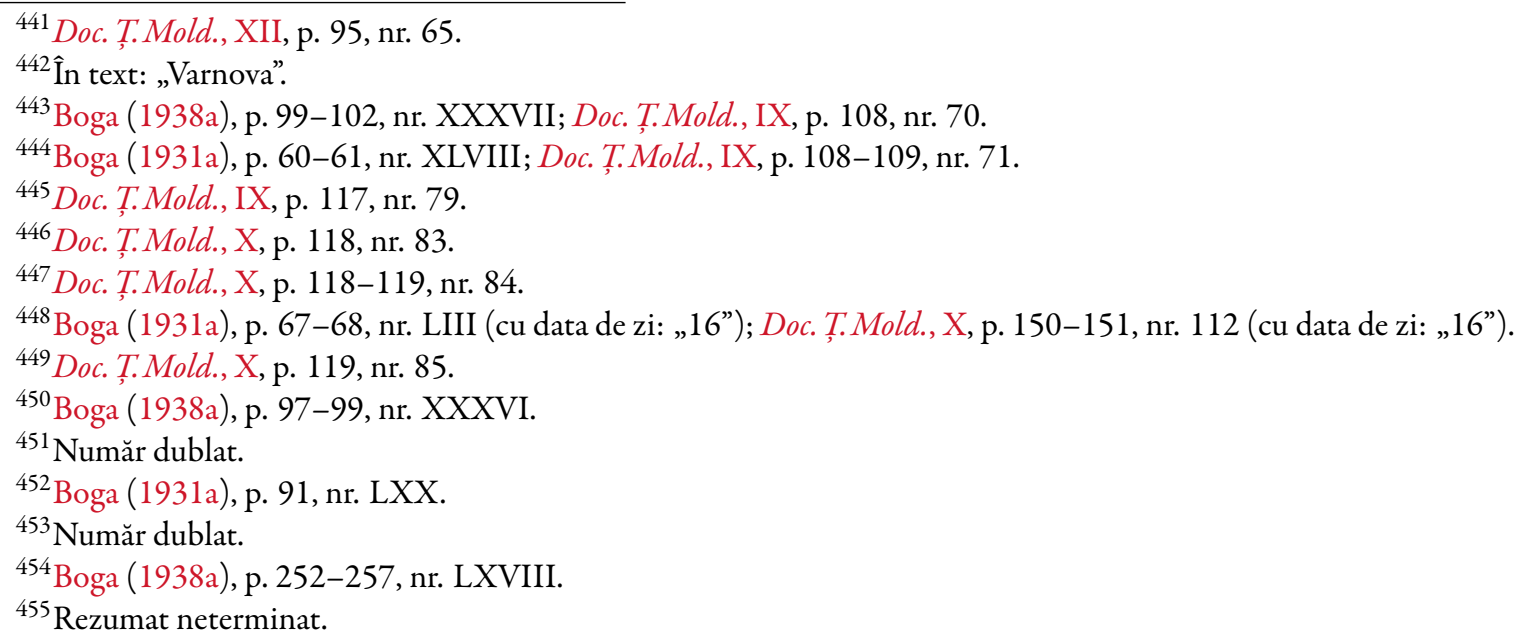




\begin{tabular}{|c|c|c|c|c|c|}
\hline 1487 & 1782 & mai & 4 & Dania lui Ioniță Jerdan pentru Șerban logofăt ${ }^{456}$ & " \\
\hline 1488 & 1802 & aprilie & 13 & Zapisul lui Vasilie Ignat pentru moșia Hidighiş & ” \\
\hline 1489 & 1823 & martie & 30 & Zapisul Ecaterinei Popa pentru o vie de la Hidighiș & ” \\
\hline 1490 & 1822 & august & 14 & Zapisul lui Axinte Mărza pentru satul „Măscăria” & " \\
\hline 1491 & 1800 & septembrie & 7 & Zapisul răzeșilor pentru moșia Zămbreni & " \\
\hline 1492 & 1813 & august & 31 & Mărturia pentru moşia Zămbreni & ” \\
\hline 1493 & 1814 & iunie & 3 & Porunca Sărdăriei Orheiu pentru moșia Zămbreni & ” \\
\hline 1494 & 1816 & noiembrie & 16 & $\begin{array}{l}\text { Hotărîrea Judecătoriei ținutului Orheiu pentru } \\
\text { moșia Modvalu }\end{array}$ & " \\
\hline 1495 & - & - & - & Spița răzeșilor moșiei Zămbreni & ” \\
\hline 1496 & 1781 & iunie & 9 & $\begin{array}{l}\text { Zapisul lui Andrei Dorin pentru moșia } \\
\text { „Măulești” } 457\end{array}$ & " \\
\hline 1497 & 1787 & iunie & 19 & $\begin{array}{l}\text { Zapisul lui Andrei Hortolomeiu pentru moșia } \\
\text { Zămbreni }{ }^{458}\end{array}$ & $"$ \\
\hline 1498 & 1797 & martie & 25 & $\begin{array}{l}\text { Zapisul lui Neculae Mereacre pentru moșia } \\
<\text { Bugeni }>459,<\text { din ținutul Orhei }>\end{array}$ & " \\
\hline 1499 & 1801 & mai & 22 & $\begin{array}{l}\text { Cartea lui Constantin Ipsilanti voievod pentru } \\
\text { moșia }<\text { Bugeni }>460\end{array}$ & ” \\
\hline 1500 & 1804 & ianuarie & 5 & $\begin{array}{l}\text { Cartea lui Alexandru Moruzi voievod pentru moșia } \\
<\text { Bugeni }>\end{array}$ & $”$ \\
\hline 1501 & 1804 & ianuarie & 22 & $\begin{array}{l}\text { Porunca Sărdăriei de Orheiu pentru moșia } \\
\text { Modvalu }^{462}\end{array}$ & " \\
\hline 1502 & 1806 & aprilie & 23 & $\begin{array}{l}\text { Cartea lui Alexandru Moruzi voievod pentru moșia } \\
\text { Bugeni }\end{array}$ & " \\
\hline 1503 & 1815 & august & 19 & Mărturia Ecaterinei Toma pentru moșia Bugeni & ” \\
\hline 1504 & - & - & - & $\begin{array}{l}\text { Zapisul Anastasiei Tiron pentru moșia < Voloseni, } \\
\text { din ținutul Orhei }>463\end{array}$ & " \\
\hline 1505 & $\frac{7177}{1669}$ & martie & 25 & $\begin{array}{l}\text { Cartea lui Duca voievod pentru moşia } \\
<\text { Tutoveni }>464\end{array}$ & " \\
\hline 1506 & $\frac{7228}{1719}$ & octombrie & 23 & $\begin{array}{l}\text { Zapisul lui Apostol Tăbârță pentru un vad de } \\
\text { moară } 465\end{array}$ & $\begin{array}{l}\text { românesc, cu trad. } \\
\text { rusească }\end{array}$ \\
\hline 1507 & $\frac{7230}{1722}$ & februarie & 17 & Zapisul lui Mogăldea pentru un vad. de moară & " \\
\hline 1508 & $\frac{7251}{1743}$ & ianuarie & 15 & $\begin{array}{l}\text { Cartea lui Constantin Neculai <Mavrocordat }> \\
\text { voievod pentru un țigan <al lui Teodor }>\text { Carp } \\
466\end{array}$ & " \\
\hline 1509 & 1785 & noiembrie & 27 & Copie după diata Ruxandrei Carp ${ }^{467}$ & " \\
\hline 1510 & 1803 & iunie & 7 & $\begin{array}{l}\text { Cartea lui Alexandru Moruzi voievod pentru moșia } \\
\text { Voloseni }\end{array}$ & ” \\
\hline 1511 & 1806 & aprilie & 26 & $\begin{array}{l}\text { Cartea lui Veniamin mitropolitul Moldovei pentru } \\
\text { moșia Cojești }\end{array}$ & ” \\
\hline 1512 & 1796 & februarie & 23 & $\begin{array}{l}\text { Copie după cartea de judecată a mitropolitului } \\
\text { pentru moșia Rădeni }\end{array}$ & $"$ \\
\hline 1513 & 1796 & februarie & 22 & Spița răzeșilor de pe moșia Brădeni & în trad. rusească \\
\hline
\end{tabular}

${ }^{456}$ Doc. T.Mold., X, p. 139, nr. 100.

${ }^{457}$ Poate „Păulești” (ținutul Orhei).

${ }^{458}$ Doc. T,. Mold., XI, p. 34-35, nr. 3 (cu data de zi: „9”).

${ }^{459}$ În text: „Buțeni”.

${ }^{460}$ În text: „Huțeni”. Este vorba despre moșia „Bugeni” (numită acum „Zâmbreni”); Doc. Ț. Mold., XII, p. 68-69, nr. 26.

${ }^{461}$ Doc. T⿱. Mold., XII, p. 222-224, nr. 224 (moșia Bugeni, numită și „Zâmbru”).

${ }^{462}$ Doc. T. Mold., XII, p. 224-226, nr. 225.

463 În text: „Voliesni”.

${ }^{464} \mathrm{MEF}, \mathrm{V}$, p. $254-255$, nr. 108.

${ }^{465}$ În text, greșit: „Tudoreni”. Boga (1930c), p. 165, nr. XXVIII; MEF, VIII, p. 45-46, nr. 25.

${ }^{466}$ Boga (1931b), p. 286-289, nr. XXIX (cu data de la Hristos calculată greșit: „1742”).

${ }^{467}$ Boga (1929a), p. 20-23, nr. XIV (cu data de zi: „26”); Doc. T.. Mold., X, p. 204-206, nr. 160 (cu data de zi: „26”). 


\begin{tabular}{|c|c|c|c|c|c|}
\hline 1514 & 1805 & ianuarie & 15 & Jalba lui Andrei Scurtul pentru moșia <Cozăști > ${ }^{468}$ & $"$ \\
\hline 1515 & 1809 & iunie & 21 & Jalba lui Vasilie „Hoțianu” pentru moșia Rădeni & ” \\
\hline 1516 & 1822 & martie & 15 & $\begin{array}{l}\text { Contract de arendare a moșiei Mereni, < din ținutul } \\
\text { Orhei> }\end{array}$ & " \\
\hline 1517 & 1811 & aprilie & 25 & Zapisul lui „Vremeav” pentru moșia Sireți & ” \\
\hline 1518 & 1824 & martie & 3 & $\begin{array}{l}\text { Învoiala între Catargiu și Tomuleț pentru schimbul } \\
\text { unor moșii }\end{array}$ & ” \\
\hline 1519 & 1821 & martie & 2 & Idem & ” \\
\hline 1520 & 1823 & martie & 8 & $\begin{array}{l}\text { Cererea lui Vasilie Deviatov pentru datoriile lui } \\
\text { Zăstov }\end{array}$ & " \\
\hline 1521 & 1824 & - & - & Socoteli de-ale poștelor din Chișinău ( 8 bucăți) & " \\
\hline 1522 & 1785 & aprilie & 13 & $\begin{array}{l}\text { Cartea lui Alexandru Mavrocordat <Firaris }> \\
\text { voievod pentru moșia Criuleni, < din ținutul } \\
\text { Orhei } 469\end{array}$ & " \\
\hline 1523 & 1783 & iunie & 21 & $\begin{array}{l}\text { Cartea lui Alexandru Constantin <Mavrocordat } \\
\text { Deli-Bey> voievod pentru moșia Criuleni }{ }^{470}\end{array}$ & ” \\
\hline 1524 & 1807 & mai & 21 & Zapisul lui Ilie pentru moșia Criuleni & ” \\
\hline 1525 & 1807 & mai & 21 & Zapisul lui Alexii pentru moșia Criuleni $^{471}$ & ” \\
\hline 1526 & 1794 & iunie & 10 & $\begin{array}{l}\text { Cartea lui Mihail Suțul voievod pentru moșia } \\
\text { Criuleni } \\
472\end{array}$ & " \\
\hline 1527 & 1794 & octombrie & 10 & $\begin{array}{l}\text { Cartea lui Mihai < Suțul > voievod pentru moșia } \\
\text { Criuleni }\end{array}$ & " \\
\hline 1528 & $\frac{7183}{1675}$ & martie & 23 & $\begin{array}{l}\text { Zapisul Acsanei, < } \text { nepoata lui > Roman, pentru } \\
\text { moșia Criuleni }{ }^{473}\end{array}$ & ” \\
\hline 1529 & $\frac{7187}{1679}$ & aprilie & 3 & Zapisul lui Focșa pentru moșia Criuleni ${ }^{474}$ & în trad. rusească \\
\hline 1530 & $\frac{7187}{1679}$ & aprilie & 1 & Zapisul lui Echim pentru moșia Criuleni ${ }^{475}$ & " \\
\hline 1531 & 1785 & august & 28 & $\begin{array}{l}\text { Cartea lui Alexandru Mavrocordat pentru moşia } \\
\text { Criuleni }^{476}\end{array}$ & " \\
\hline 1532 & 1807 & august & 5 & Zapisul lui Luchian pentru moșia Criuleni & ” \\
\hline 1533 & $\frac{7267}{1758}$ & octombrie & 27 & Zapisul lui Loghin <pentru moșia Criuleni> & ” \\
\hline 1534 & 1807 & mai & 21 & $\begin{array}{l}\text { Zapisul lui }<\text { Scurtulencu }>^{477}<\text { pentru moșia } \\
\text { Criuleni }>478\end{array}$ & " \\
\hline 1535 & 1785 & septembrie & 13 & Zapisul răzeșilor din Criuleni pentru cîteva părți & ” \\
\hline 1536 & 1793 & martie & 27 & $\begin{array}{l}\text { Cartea lui Mihail Constantin Suțul voievod pentru } \\
\text { moșia Criuleni }{ }^{479}\end{array}$ & ” \\
\hline 1537 & $\frac{7259}{1751}$ & mai & 27 & $\begin{array}{l}\text { Zapisul lui Vasilie <Macri }{ }^{480} \text { pentru jumătate de } \\
\text { sat din Criuleni, <ținutul Orhei }>481\end{array}$ & ” \\
\hline 1538 & 1795 & mai & 2 & Porunca Sedăriei de Orheiu pentru moșia Criuleni & ” \\
\hline
\end{tabular}

\footnotetext{
${ }^{468}$ În text: „Cojăști”. Doc. T,.Mold., XII, p. 283, nr. 296.

${ }^{469}$ Doc. T. Mold., X, p. 191, nr. 143.

${ }^{470}$ Doc. T,. Mold., X, p. 151-152, nr. 113. Ambele documente din această zi sînt zapise de vînzare către Mitropolia Moldovei.

${ }^{471}$ Doc. T. Mold. (2016), p. 52-53, nr. 56.

${ }^{472}$ Doc. T. Mold., XI, p. 183, nr. 137.

${ }^{473}$ Boga (1937a), p. 66-67, nr. II (cu data de an greșită: „1676”); MEF, VI, p. 93-95, nr. 25.

${ }^{474}$ Boga (1937a), p. 68, nr. IV.

${ }^{475}$ Boga (1937a), p. 67-68, nr. III; MEF, VI, p. 112-113, nr. 32.

${ }^{476}$ Doc. T,. Mold., X, p. 200-201, nr. 156.

${ }^{477}$ În text: „Scutulnicu”.

${ }^{478}$ Doc. T.Mold. (2016), p. 51, nr. 54.

${ }^{479}$ Doc. T. Mold., XI, p. 132-133, nr. 90.

${ }^{480}$ În text, greșit: „maiu”.

${ }^{481}$ Boga (1929a), p. 11-12, nr. VIII (această jumătate de sat a fost dăruită Mitropoliei din Iași); Doc. Ț. Mold., IX, p. 21,
} nr. 1; 


\begin{tabular}{|c|c|c|c|c|c|}
\hline 1539 & 1807 & mai & 21 & Zapisul lui Dumitru pentru o parte din Criuleni ${ }^{482}$ & $"$ \\
\hline 1540 & $\frac{7187}{1679}$ & august & 15 & $\begin{array}{l}\text { Zapisul lui Postolache pentru o parte din } \\
\text { Criuleni }{ }^{483}\end{array}$ & " \\
\hline 1541 & - & - & - & $\begin{array}{l}\text { Zapisul <lui Ștefan }>{ }^{484} \text { pentru o parte din } \\
\text { Criuleni }{ }^{485}\end{array}$ & $"$ \\
\hline 1542 & $\frac{7127}{1619}$ & - & - & Zapisul Ilenii <pentru o parte din Criuleni > & " \\
\hline 1543 & 1619 & martie & 5 & Zapisul lui Vlasie < pentru o parte din Criuleni ${ }^{486}$ & " \\
\hline 1544 & 1807 & aprilie & 12 & $\begin{array}{l}\text { Zapisul lui Druhuș < pentru o parte din } \\
\text { Criuleni }>487\end{array}$ & $"$ \\
\hline 1545 & 1798 & august & 8 & $\begin{array}{l}\text { Zapisul lui Ioan Jora }<\text { pentru o parte din } \\
\text { Criuleni }>488\end{array}$ & $"$ \\
\hline 1546 & 1794 & octombrie & 21 & $\begin{array}{l}\text { Cartea de judecată a Divanului <pentru o parte din } \\
\text { Criuleni> }\end{array}$ & $"$ \\
\hline 1547 & 1816 & februarie & 16 & Spița răzeșilor satului Zahoreni & 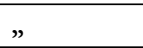 \\
\hline 1548 & 1819 & mai & 12 & Zapisul lui Mihalache pentru moșia Racovățul & ” \\
\hline 1549 & 1819 & septembrie & 20 & Alegerea stînjenilor moșiilor Hăjdeenii, „Boeștii” & " \\
\hline 1550 & 1819 & septembrie & 20 & $\begin{array}{l}\text { Referatul lui Jerdan vornicul de poartă pentru } \\
\text { alegerea moșiilor Hăjdeenii, „Boeștii” }\end{array}$ & $"$ \\
\hline 1551 & 1805 & aprilie & 22 & Răvașul Serdăriei către Luca Solovei (cu o copie) & 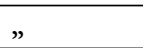 \\
\hline 1552 & 1821 & mai & 29 & Vichilimeaua dată de Toader Stegar lui Gh. Gore & ” \\
\hline 1553 & 1810 & octombrie & 12 & $\begin{array}{l}\text { Mărturia lui Gh. Gonțe pentru nepotul său, } \\
\text { Bogdănaș }\end{array}$ & $"$ \\
\hline 1554 & 1815 & iunie & 9 & $\begin{array}{l}\text { Mărturia lui N. C. Dumbravă pentru pricina lui } \\
\text { Capșa }\end{array}$ & $"$ \\
\hline 1555 & 1810 & iunie & 16 & Zapisul răzeșilor din Hulboca dat lui Bogdanaș & ” \\
\hline 1556 & 1827 & septembrie & 8 & $\begin{array}{l}\text { Porunca Comisiei hotărîturilor către Judecătoria } \\
\text { ținutului Orhei }\end{array}$ & românesc \\
\hline 1557 & 1806 & iulie & 10 & Mărturia lui Agapie Vicol pentru moșia Moruzeni & \# \\
\hline 1558 & - & - & - & $\begin{array}{l}\text { Izvod de părțile din care se compune moșia } \\
\text { Bălăneștii }\end{array}$ & $"$ \\
\hline 1559 & 1783 & ianuarie & 24 & $\begin{array}{l}\text { Copie. Cartea lui Alexandru Constantin } \\
<\text { Mavrocordat Deli-Bey }>\text { pentru moșia Bravicea }\end{array}$ & " \\
\hline 1560 & 1813 & august & 4 & $\begin{array}{l}\text { Cererea lui Vasile Roșca pentru niște bani } \\
\text { împrumut }\end{array}$ & $"$ \\
\hline 1561 & 1821 & noiembrie & 19 & Zapisul răzeșilor pentru moșia Negrești & ” \\
\hline 1562 & $\frac{7173}{1665}$ & iulie & 10 & $\begin{array}{l}\text { Copie. Cartea lui Istratie Dabija voievod pentru } \\
\text { Bravicea }<\text { și Dișcova, din ținutul Orhei }>489\end{array}$ & $"$ \\
\hline 1563 & 1803 & aprilie & - & $\begin{array}{l}\text { Porunca Divanului către Ștefan Cociul pentru } \\
\text { Bravicea }\end{array}$ & ” \\
\hline 1564 & $\frac{7231}{1723}$ & mai & 20 & $\begin{array}{l}\text { Copie. Cartea lui Mihai Racoviță voievod pentru } \\
\text { Bravicea }\end{array}$ & $"$ \\
\hline 1565 & $\frac{7111}{1603}$ & ianuarie & 20 & $\begin{array}{l}\text { Suret după cartea lui Movilă voievod pentru moșia } \\
\text { Bravicea } 490\end{array}$ & " \\
\hline 1566 & $\frac{7284}{1776}$ & iulie & 20 & $\begin{array}{l}\text { Copie. Cartea lui Alexandru Constantin } \\
<\text { Mavrocordat }>\text { voievod pentru moșia Bravicea }\end{array}$ & $"$ \\
\hline 1567 & 1822 & noiembrie & 17 & Cererea lui Balaban pentru niște părți din Bacșani & ” \\
\hline
\end{tabular}

${ }^{482}$ Doc. T. Mold. (2016), p. 53-54, nr. 57.

${ }^{483}$ Boga (1937a), p. 68-69, nr. V; MEF, VI, p. 117-118, nr. 35.

${ }^{484}$ În text: „Ștefania”.

${ }^{485}$ Doc. T,.Mold. (2016), p. 52, nr. 55 (cu data: „21 mai 1807”).

${ }^{486}$ Boga (1932a), p. 145-146, nr. V (cu data: „5 mai 1618”).

${ }^{487}$ Doc. T.. Mold. (2016), p. 40-42, nr. 39, 40 (două zapise ale fraților Druhuş).

${ }^{488}$ Boga (1929a), p. 24-25, nr. XVI (cu data de zi: „6”); Doc. T. Mold., XI, p. 295, nr. 232 (cu data de zi: „6”).

${ }^{489}$ Boga (1930c), p. 154-155, nr. XVIII.

${ }^{490}$ MEF, I, p. $188-189$, nr. 81. 


\begin{tabular}{|c|c|c|c|c|c|}
\hline 1568 & 1817 & decembrie & 25 & Spița de neam a Bieștilor & $\#$ \\
\hline 1569 & 1821 & martie & 23 & $\begin{array}{l}\text { Marturie cu privire la moșia Biești, < din ținutul } \\
\text { Orhei> }\end{array}$ & ” \\
\hline 1570 & 1820 & septembrie & 20 & Zapisul răzeșilor moșiei Bieștilor & 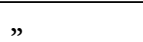 \\
\hline 1571 & 1800 & februarie & 4 & Cartea Divanului pentru moșia Răsteeni ${ }^{491}$ & $\#$ \\
\hline 1572 & 7229 & octombrie & 3 & $\begin{array}{l}\text { Cartea lui Mihai Racoviță voievod pentru pentru } \\
\text { moșia Corozeni }{ }^{492}\end{array}$ & " \\
\hline 1573 & 1821 & octombrie & 26 & $\begin{array}{l}\text { Scrisoarea lui <Mihai Sturza > }{ }^{493} \text { către < Ioniță }> \\
\text { Galin, <la Măcărești> }\end{array}$ & $"$ \\
\hline 1574 & 1811 & noiembrie & 10 & Contract de arendare a moșiei Budești & 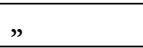 \\
\hline 1575 & 1817 & octombrie & 30 & Contract de arendare a moșiei Măcărești & 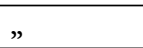 \\
\hline 1576 & 1818 & septembrie & 25 & Scrisoarea lui Măcărescu către Ioniță Galin & ” \\
\hline 1577 & - & - & - & $\begin{array}{l}\text { Compunere, în limba poloneză, a lui Alexandru } \\
\text { Hajdău }\end{array}$ & $"$ \\
\hline 1578 & 1821 & - & - & Scrisori diverse, rusești ( 15 bucăți) & rusești \\
\hline 1579 & 1816 & - & - & $\begin{array}{l}\text { Chitanțe, de diverse sume, semnate de Dochița } \\
\text { vorniceasa ( } 12 \text { bucăți) }\end{array}$ & ” \\
\hline 1580 & 1813 & - & - & Izvoade de documente (39 bucăţi) & românești \\
\hline 1581 & 1823 & - & - & Diverse socoteli ale casei Hancicov (10) & rusești \\
\hline 1582 & - & - & - & Diverse socoteli scrise evreiește (17) & \\
\hline 1583 & 1798 & august & 16 & Spița răzeșilor din Răcești & românesc \\
\hline 1584 & $\frac{7253}{1705}$ & iunie & 5 & $\begin{array}{l}\text { Copie după cartea lui Antiohie <Cantemir > } \\
\text { voievod pentru siliștea Onești } 495\end{array}$ & $"$ \\
\hline 1585 & - & - & - & Spița neamului < din moșia > Onești & 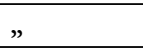 \\
\hline 1586 & - & - & - & Spița răzeșilor din Onești & ” \\
\hline 1587 & 1822 & iunie & 20 & $\begin{array}{l}\text { Porunca Isprăvnicie Orheiu pentru zestrea fetei lui } \\
\text { Jardan }\end{array}$ & $"$ \\
\hline 1588 & 1820 & martie & 25 & Diata lui Dumitru Jardan $<$ vornic de poartă $>496$ & ” \\
\hline 1589 & 1820 & ianuarie & 22 & Izvod de vitele rămase după moartea lui Jardan & ” \\
\hline $\begin{array}{c}1589 \\
497\end{array}$ & 1819 & noiembrie & 6 & Izvod de via ce este în fața satului Rădeni & " \\
\hline 1590 & - & - & - & Polițe semnate de diverși (38 bucăți) & rusești \\
\hline 1591 & 1829 & aprilie & 30 & $\begin{array}{l}\text { Hotărîrea Comisiei hotărăturilor pentru moșia } \\
\text { „Bălca” }\end{array}$ & ” \\
\hline 1592 & 1812 & septembrie & 20 & $\begin{array}{l}\text { Cartea Divanului Molvodei pentru datoria lui } \\
\text { Simion Burchi }\end{array}$ & românesc \\
\hline 1593 & 1790 & mai & 1 & Chitanța lui Simion Burchi & ” \\
\hline 1594 & 1790 & aprilie & 9 & Scrisoarea lui Ioniță Anton pentru niște bani & $\#$ \\
\hline 1595 & 1790 & aprilie & 1 & Scrisoarea lui Ioniță Anton pentru bani & ” \\
\hline 1596 & - & - & - & Diverse chitanțe de bani semnate de I. Cațichi & " \\
\hline 1597 & 1767 & februarie & 27 & Cartea de judecată, pentru judecata lui Ursul Popa & $\#$ \\
\hline 1598 & 1828 & noiembrie & 28 & Contract de arendare a moşiei Cobâlca & $\#$ \\
\hline 1599 & 1828 & - & - & Chitanțe de diverse sume, în 5 piese & rusești \\
\hline 1600 & 1814 & noiembrie & 16 & Scrisoarea lui Paninopol către < Enache $>$ Panait $^{498}$ & românesc \\
\hline 1601 & 1829 & ianuarie & 15 & $\begin{array}{l}\text { Contract de arendare a moșiei Sârcova, < din ținutul } \\
\text { Orhei> }\end{array}$ & ” \\
\hline 1602 & 1792 & iunie & 17 & Porunca Dărdăriei Orhei către răzășii Coești & $”$ \\
\hline 1603 & - & - & - & Diverse polițe și chitanțe (17 bucăți) & rusesc \\
\hline
\end{tabular}

491 „Răsteu” (ținutul Hotin).

${ }^{492}$ MEF, VIII, p. 50-52, nr. 30.

${ }^{493}$ În text: „Măcărescu”.

${ }^{494} \mathrm{Boga}(1928$ b), p. $78-79$, nr. XCIX.

${ }^{495}$ Boga (1930a), p. 349-350, nr. III; MEF, VI, p. 228-229, nr. 90.

${ }^{496}$ Boga (1929a), p. 38-52, nr. XXIX (cu data de zi: „20”).

${ }^{497}$ Număr dublat.

${ }^{498}$ Boga (1928b), p. $28-29$, nr. XXXI. 


\begin{tabular}{|c|c|c|c|c|c|}
\hline 1604 & $\frac{7114}{1706}$ & iunie & 14 & $\begin{array}{l}\text { Zapisul lui Gheorghe, <fiul lui > Ursul < Popescu>, } \\
\text { pentru un pămînt din <tîrgul> Orhei }{ }^{499}\end{array}$ & românesc \\
\hline 1605 & $\frac{7212}{1704}$ & - & - & $\begin{array}{l}\text { Cartea lui Mihai Racoviță voievod pentru o moară } \\
\text { din Orhei } \\
500\end{array}$ & $"$ \\
\hline 1606 & $\frac{7218}{1710}$ & februarie & 18 & Zapisul lui Gavril pentru niște pămînt din Orhei & " \\
\hline 1607 & $\begin{array}{l}\langle 7217\rangle \\
\langle 1709\rangle \\
501\end{array}$ & iunie & 1 & $\begin{array}{l}\text { Cartea lui Mihai Racoviță voievod dată lui } \\
\text { Constantin }\end{array}$ & ” \\
\hline $\begin{array}{c}1608 \\
502\end{array}$ & & & & & ” \\
\hline 1609 & 1824 & august & 26 & Cererea lui Ioniță Roșca pentru niște bani & ” \\
\hline 1610 & 1822 & mai & 12 & Vichilimeaua dată de Roșca & ” \\
\hline 1611 & - & - & - & $\begin{array}{l}\text { Părțile de moșie ale lui Ioan Barzan, <în > diverse } \\
\text { moșii }\end{array}$ & ” \\
\hline 1612 & 1824 & august & 26 & $\begin{array}{l}\text { Jalba lui Vasile Roșca pentru moșia Crasnășăni, } \\
\text { <din ținutul Orhei> }\end{array}$ & ” \\
\hline 1613 & 1822 & octombrie & 26 & Protestul lui Vasile Roșca & ” \\
\hline 1614 & 1824 & august & 26 & Scrisoarea lui Petre Galița & ” \\
\hline 1615 & 1824 & iunie & 10 & Învoiala între Ștefan Gheorghiu și P. Galița & ” \\
\hline 1616 & 1822 & august & 1 & Scrisoarea lui P. Galița pentru bani & ” \\
\hline 1617 & 1822 & septembrie & 9 & Scrisoarea lui Petru Galița ${ }^{503}$ & ” \\
\hline 1618 & 1838 & iunie & 8 & Diata lui Demi Devlenitol $^{504}$ & rusesc \\
\hline 1619 & 1831 & iunie & 27 & Diata lui Dimitrie $<$ Iofce $>^{505}$ & românesc \\
\hline 1620 & $\begin{array}{l}\frac{7128}{1619} \\
506\end{array}$ & noiembrie & 3 & $\begin{array}{l}\text { Copie după cartea lui Gașpar Grațiani pentru satul } \\
<\text { Doljocul, din ținutul Hotin }>507\end{array}$ & ” \\
\hline 1621 & $\frac{7140}{1631}$ & septembrie & 15 & $\begin{array}{l}\text { Copie după cartea lui Moise voievod pentru satul } \\
\text { Doljocul <și pentru alte sate, care s-au împărțit } \\
\text { între frații Prăjescu> }>^{508}\end{array}$ & ” \\
\hline 1622 & 1852 & - & - & Scrisori de-ale lui Pavli, în grecește & grecește \\
\hline 1623 & 1787 & septembrie & 30 & $\begin{array}{l}\text { Hotarnica moșiei Bogzăștilor, <din ținutul } \\
\text { Orhei }{ }^{509}\end{array}$ & românesc \\
\hline 1624 & 1822 & octombrie & 25 & Învoiala între „Unsti Dimi” și „Iani Cotă” & ” \\
\hline 1625 & 1822 & iunie & 13 & $\begin{array}{l}\text { Zapisul lui Grigore Hecian pentru o parte din } \\
\text { Dănești }\end{array}$ & ” \\
\hline 1626 & 1806 & mai & 20 & Împărțeala între M. Donici și S. Feodosiu & " \\
\hline 1627 & 1760 & martie & - & $\begin{array}{l}\text { Cartea lui Ioan Teodor <Calimah > voievod pentru } \\
\text { niște țigani }\end{array}$ & $\begin{array}{l}\text { românesc, cu trad. } \\
\text { rusească }\end{array}$ \\
\hline 1628 & 1772 & - & - & Izvodul de moșiile ce are Leca & ” \\
\hline 1629 & 1779 & iunie & 12 & Izvodul de împărțeala între Doncești & românesc \\
\hline
\end{tabular}

\footnotetext{
${ }^{499}$ Boga (1929a), p. 9, nr. IV.

${ }^{500}$ Boga (1930a), p. 349, nr. II (cu data: 20 iulie $1704<7212>$ ); MEF, VI, p. 221-222, nr. 86 (cu data: 20 iulie 1704 $<7212>$ ").

${ }^{501}$ În text, data greșită: „,7257 (1749)”. Dacă ultima cifră din veleat este corectă, atunci actul poate fi din 7217 (1709) sau 7227 (1719).

${ }^{502}$ Rezumatul nu a fost copiat, rămînînd loc liber în text.

${ }^{503}$ Boga (1928b), p. 84-85, nr. CVII, cu data de zi: 9.

${ }^{504}$ Este vorba despre Nicolae Demi, născut în localitatea Delvinaki din Grecia (Poștarencu, 2013, p. 112-113).

${ }^{505}$ În text, greșit: „Ionel”. Boga (1929a), p. 71, nr. LXII.

${ }^{506}$ În text, data greșită: „7120 (1612)”.

507 În text, greșit: „Dolgol”. Boga (1929d), p. 11, nr. VI.

${ }^{508}$ Boga (1929d), p. 13-14, nr. XI; MEF, III, p. 272-273, nr. 134.

${ }^{509}$ În text, data greșită: „1782”. Boga (1938a), p. 124-143, nr. XLV.
} 


\begin{tabular}{|c|c|c|c|c|c|}
\hline $\begin{array}{c}1640 \\
510\end{array}$ & 1813 & octombrie & 16 & $\begin{array}{l}\text { Hotărîrea Departamentulu I-iu al Basarabiei în } \\
\text { pricina lui I. Sava }\end{array}$ & " \\
\hline 1641 & $\begin{array}{l}<1806> \\
511\end{array}$ & iunie & 6 & Jalba lui Stratan către domn & " \\
\hline 1642 & 1806 & iunie & 4 & Hotărîrea Divanului pentru moșia Inești & ” \\
\hline 1643 & 1808 & februarie & 20 & $\begin{array}{l}\text { Hotărîrea Departamentului Pricinilor Streine } \\
\text { pentru moșia Ineștii }\end{array}$ & 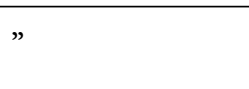 \\
\hline 1644 & 1811 & iulie & 10 & Alegerea părților din Inești ale lui Sava & ” \\
\hline 1645 & $\frac{7262}{1754}$ & august & 27 & $\begin{array}{l}\text { Cartea lui Matei Ghica voievod pentru moșia } \\
\text { Recea }^{512}\end{array}$ & ” \\
\hline 1646 & $\begin{array}{l}1764 \\
513\end{array}$ & octombrie & 5 & Copia hotarnicei moșiei Holboca ${ }^{514}$ & " \\
\hline 1647 & 1853 & - & - & Poliță de diverse sume ( 2 bucăți) & rusesc \\
\hline 1648 & 1834 & februarie & 4 & $\begin{array}{l}\text { Diata Lupei, <soția postelnicelului Lupu > } \\
\text { Silescul }\end{array}$ & " \\
\hline 1649 & 1804 & mai & 18 & Zapisul preotului Ilie Sângerean & ” \\
\hline 1650 & 1823 & - & - & $\begin{array}{l}\text { Chitanțe, pentru diferite sume, iscălite de Petrachi } \\
\text { portar }\end{array}$ & românesc \\
\hline 1651 & 1669 & noiembrie & 7 & $\begin{array}{l}\text { Hotarnica moșiei Cobălcinu, < din ținutul } \\
\text { Hotin> } 516\end{array}$ & ” \\
\hline 1652 & 1818 & mai & 7 & $\begin{array}{l}\text { Scrisoarea către Iordachi Dimitriu, în chestiuni de } \\
\text { bani (din anul 1818; } 10 \text { bucăți) }\end{array}$ & grecește \\
\hline 1653 & 1810 & octombrie & 15 & Cartea Divanului Moldovei pentru moșia Pererita & românesc \\
\hline 1654 & 1819 & iulie & 12 & $\begin{array}{l}\text { Hotărîrea Judecătoriei ținutului Orhei pentru } \\
\text { moșia Onțănii }\end{array}$ & $\begin{array}{l}\text { românesc, cu trad. } \\
\text { rusească }\end{array}$ \\
\hline 1655 & 1820 & decembrie & 19 & $\begin{array}{l}\text { Hotărîrea Judecătoriei Basarabiei pentru moșia } \\
\text { Marșinții }\end{array}$ & " \\
\hline 1656 & 1820 & decembrie & 19 & Planul moșiilor Marșinții, Forosna & românesc \\
\hline 1657 & 1818 & februarie & 8 & Partea lui Odobaș din moșia Suriceni & $\begin{array}{l}\text { românesc, cu trad. } \\
\text { rusească }\end{array}$ \\
\hline 1658 & 1819 & martie & 10 & Hotarnica moșiei Suriceni & ” \\
\hline 1659 & 1777 & iulie & 12 & $\begin{array}{l}\text { Mărturia hotarnică a moșiei Dânceni, <care s-a } \\
\text { numit Duralia și Hlobu, din ținutul Lăpușna > } 517\end{array}$ & " \\
\hline 1660 & 1777 & august & 9 & $\begin{array}{l}\text { Cartea lui Grigore Ghica voievod pentru moșia } \\
\text { Dângeni }{ }^{118}\end{array}$ & ” \\
\hline 1661 & 1812 & aprilie & 4 & $\begin{array}{l}\text { Cartea Divanului Moldovei pentru Suriceni, }<\text { din } \\
\text { ținutul Orhei }>519\end{array}$ & $”$ \\
\hline 1662 & - & - & - & Partea lui Postolachie din moșia Suriceni & ” \\
\hline 1663 & - & - & - & Mărturia pentru partea lui Luca Suriceni & ” \\
\hline 1664 & 1768 & - & - & $\begin{array}{l}\text { Zapisul lui Panaiti < prin care vinde ceva }>\text { popii lui } \\
\text { Postolachi }\end{array}$ & " \\
\hline 1665 & 1748 & august & 30 & Zapisul lui Nastase Noroce pentru moșia Suriceni & ” \\
\hline 1666 & 1674 & februarie & 20 & Zapisul preotesii Nastii pentru moșia Zubreștii & ” \\
\hline 1667 & 1656 & - & - & Zapisul lui Balaci pentu o parte din Suriceni ${ }^{520}$ & ” \\
\hline
\end{tabular}

\footnotetext{
${ }^{510}$ Așa în text. Numerele 1630-1639 lipsesc.

${ }^{511}$ În text, data greșită: „1656”.

${ }^{512}$ Doc. T. Mold., IX, p. 39-41, nr. 19 (cu data de zi: „26”).

${ }^{513}$ În text, data greșită: „1704”.

${ }^{514}$ Boga (1938a), p. 58-63, nr. XXV.

${ }^{515}$ Boga (1929a), p. 71-73, nr. XLIII.

${ }^{516}$ Boga (1938a), p. $28-29$, nr. X.

${ }^{517}$ Boga (1938a), p. 83-86, nr. XXXII; Doc. T. Mold., X, p. 70-72, nr. 47.

${ }^{518}$ În text: „Dănceni”. Boga (1931a), p. 52-58, nr. XLIV; Doc. Ţ. Mold., X, p. 72-76, nr. 48.

${ }^{519}$ Documentul nu este o „carte a Divanului”, ci o mărturie hotarnică a moşiei Suriceni; Boga (1938a), p. 271-286, nr.

${ }^{520} \mathrm{MEF}, \mathrm{IV}$, p. $256-258$, nr. 114.
} LXXIV. 


\begin{tabular}{|c|c|c|c|c|c|}
\hline 1668 & 1652 & - & - & $\begin{array}{l}\text { Zapisul <Cărpoaiei }{ }^{521} \text { pentru o parte din } \\
\text { Suriceni }{ }^{522}\end{array}$ & $”$ \\
\hline 1669 & 1649 & august & 15 & $\begin{array}{l}\text { Cartea lui Vasile voievod pentru moșia Suriceni, } \\
<\text { ținutul Lăpușna }>523\end{array}$ & " \\
\hline 1670 & 1818 & februarie & 7 & Hotarnica moșiei Suriceni & ” \\
\hline 1671 & 1818 & februarie & 2 & Socoteala stînjenilor moșiei Suriceni & ” \\
\hline 1672 & - & - & - & Izvod de delnițele moșiei Suriceni & ” \\
\hline 1673 & 1661 & iunie & 29 & $\begin{array}{l}\text { Copie după cartea lui Ștefan voievod pentru moșia } \\
<\text { Sipoteni, din ținutul Orhei }>524\end{array}$ & ” \\
\hline 1674 & 1814 & iulie & 14 & Zapisul lui P. Cazimir pentru 100.000 lei & ” \\
\hline 1675 & 1827 & - & - & Semnături și socoteli ale lui P. Cazimir & ” \\
\hline 1676 & 1816 & octombrie & 21 & Scrisoarea „Toniței” către P. Cazimir & ” \\
\hline 1677 & 1813 & aprilie & 1 & $\begin{array}{l}\text { Contract de arendare a moșiei Chelmești, <din } \\
\text { ținutul Hotin }>\end{array}$ & " \\
\hline 1678 & 1822 & ianuarie & 22 & Scrisoarea lui C. Sturza către P. Cazimir & rusesc \\
\hline 1679 & 1815 & decembrie & 22 & Scrisoare către P. Cazimir & românesc \\
\hline 1680 & 1815 & - & - & Polițe și chitanțe semnate de P. Cazimir, 10 bucăți. & ” \\
\hline 1681 & 1822 & decembrie & 3 & Zapisul lui Tudosă pentru o casă din Isacova & ” \\
\hline 1682 & 1820 & decembrie & 18 & Zapisul lui Tudosă pentru un „căz” ${ }^{25}$ & ” \\
\hline 1683 & 1818 & mai & 3 & Porunca Sărdăriei Orheiu către ocolașul Culei & ” \\
\hline 1684 & 1810 & iulie & 23 & $\begin{array}{l}\text { Porunca Sărdăriei de Orheiu către căpitanul de } \\
\text { mazili din Cula }\end{array}$ & $"$ \\
\hline 1685 & 1823 & mai & 17 & Zapisul lui I. Damaschin pentru o parte de moșie & ” \\
\hline 1686 & 1822 & martie & 23 & $\begin{array}{l}\text { Hotărîrea Judecătoriei politicești a Basarabiei în } \\
\text { pricina lui Mirăuță }\end{array}$ & " \\
\hline 1687 & 1824 & ianuarie & 12 & Contract de închiriere a unor dugheni din Chișinău & ” \\
\hline 1688 & 1823 & octombrie & 5 & Contract de închiriere a unor dugheni din Chișinău & ” \\
\hline 1689 & 1824 & septembrie & 10 & Foaia de zestre a Zoiței ${ }^{526}$ & ” \\
\hline 1690 & 1825 & martie & 3 & $\begin{array}{l}\text { Scrisoarea lui }<\text { Onofrei }{ }^{527} \text { Sava către Costachi } \\
<\text { Stoian }>528\end{array}$ & $"$ \\
\hline 1691 & 1825 & februarie & 15 & Jalba lui Costachi Stoian & ” \\
\hline 1692 & 1825 & ianuarie & 1 & Spița neamului „Hore” & ” \\
\hline 1693 & 1818 & ianuarie & 30 & Mărturie pentru părțile din moșia Suriceni. & ” \\
\hline 1694 & 1821 & octombrie & 2 & Zapisul lui Potlog pentru o vie & ” \\
\hline 1695 & 1822 & martie & 17 & Mărturia mazililor din Isacova dată lui Gugiuman & ” \\
\hline 1696 & 1822 & aprilie & 23 & Schimbul făcut între preotul Andrei și Ion Madan & ” \\
\hline 1697 & 1822 & iulie & 12 & $\begin{array}{l}\text { Mărturia răzeșilor din „Băciciu” pentru Ion } \\
\text { Antimici }\end{array}$ & ” \\
\hline $\begin{array}{c}1697 \\
529\end{array}$ & 1822 & iunie & 8 & Mărturia răzeșilor din Trușeni pentru Ion Madan & ” \\
\hline 1698 & 1802 & iunie & 3 & $\begin{array}{l}\text { Cartea lui Alexandru Suțul voievod pentru pentru } \\
\text { moșia Bogzăști, <din ținutul Orhei> } 530\end{array}$ & $”$ \\
\hline 1699 & 1812 & martie & 15 & Mărturia hotarnică a moșiei Seliște & ” \\
\hline 1700 & 1816 & martie & 2 & Zapisul pentru o parte din moșia Seliște & ” \\
\hline 1701 & 1816 & aprilie & 29 & Porunca căpitanului de mazili către V. Buciușcan & ” \\
\hline 1702 & 1819 & mai & 24 & Jalba lui Curchi To $<\mathrm{a}>\mathrm{d}<\mathrm{er}>$ în pricina cu Roșca & ” \\
\hline
\end{tabular}

${ }^{521}$ În text, greșit: „lui Cărpac”.

${ }^{522}$ Boga (1932a), p. 155-156, nr. XVIII (numai cu data de an: „1652”, și cu veleatul greșit: „7150”).

${ }^{523}$ Boga (1929e), p. 86-87, nr. V.

${ }^{524}$ În text, greșit: „Suriceni”. Boga (1930c), p. 147-148, nr. XI.

${ }^{525}$ Cuvînt greu de întregit.

${ }^{526}$ Boga (1928a), p. 38-40, nr. XXV.

${ }^{527}$ În text, greșit: „Andrei”.

${ }^{528}$ Boga (1928b), p. 110, nr. CXLVI.

${ }^{529}$ Număr dublat.

${ }^{530}$ Doc. T,.Mold., XII, p. 110, nr. 85. 


\begin{tabular}{|c|c|c|c|c|c|}
\hline 1703 & 1810 & iulie & 10 & Zapisul lui Simion pentru o parte din Ghermănești & " \\
\hline 1704 & 1851 & iunie & 14 & Zapisul pentru pășunatul vitelor din Ghermănești & ” \\
\hline 1705 & 1856 & iunie & 25 & Zapisul lui T. Gheorghe pentru o parte de moșie & ” \\
\hline 1706 & - & - & - & Socotelile lui Ion Cheșcu & rusește \\
\hline 1707 & 1809 & - & - & $\begin{array}{l}\text { Diploma de decorații (pergament) a lui Vișnevschi } \\
\text { (6 bucăți) }\end{array}$ & " \\
\hline 1708 & - & - & - & Atestate de studii ale lui Vișnevschi ( 5 bucăți). & ” \\
\hline 1709 & 1826 & noiembrie & 19 & Act de vînzare a unei părți din Peresecina & \\
\hline 1710 & 1641 & octombrie & 22 & Cartea lui Vasile voievod pentru moșia Căzănești ${ }^{531}$ & trad. rusească \\
\hline 1711 & - & - & - & $\begin{array}{l}\text { Cartea lui Alexandru voievod pentru moșia moșia } \\
\text { Cobâlca }\end{array}$ & " \\
\hline 1712 & 1822 & februarie & 1 & Chitanță iscălită de D. „Chendrenu” & românesc \\
\hline 1713 & 1822 & - & - & Poliță semnată de Dicescul & ” \\
\hline 1714 & 1821 & august & 23 & Chitanța lui Cosmidi pentru 200 lei & grecesc. \\
\hline 1715 & 1822 & aprilie & 24 & Contract de arendare a moșiei „Cimișeni” & ” \\
\hline 1716 & 1818 & martie & 19 & Chitanța lui M. Cosmidi pentru 1.000 galbeni & ” \\
\hline 1717 & 1825 & ianuarie & 16 & Contract de arendare a satului Dereneu & românesc \\
\hline 1718 & 1826 & ianuarie & 24 & $\begin{array}{l}\text { Învoiala între Iacob Abramovici și negustorul din } \\
\text { Chișinău }\end{array}$ & " \\
\hline 1719 & 1817 & august & 22 & $\begin{array}{l}\text { Referatul Divanului către domn în pricina lui } \\
\text { Mereacre }\end{array}$ & " \\
\hline 1720 & 1817 & august & 22 & $\begin{array}{l}\text { Referatul Divanului către domn în pricina lui } \\
\text { Calmuțchi }\end{array}$ & " \\
\hline 1721 & 1820 & aprilie & 1 & Polița, de lei 4.820, semnată de Racovakov & 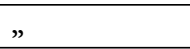 \\
\hline 1722 & 1823 & ianuarie & 8 & Scrisoarea lui $<$ Racovakov $>{ }^{532}$ pentru bani & " \\
\hline 1723 & 1826 & ianuarie & 20 & Diata lui Damaschin din Cojuşna ${ }^{533}$ & 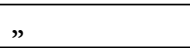 \\
\hline 1724 & 1827 & aprilie & 18 & Adeverința dată fraților Damaschin & ” \\
\hline 1725 & 1826 & decembrie & 16 & $\begin{array}{l}\text { Hotărîrea Judecătoriei ținutului Orheiu în pricina } \\
\text { lui Damaschin }\end{array}$ & $"$ \\
\hline $\begin{array}{c}1725 \\
534\end{array}$ & 1805 & august & 25 & Hotarnica moșiei Ghermănești ${ }^{535}$ & " \\
\hline 1726 & 1811 & martie & 24 & Zapisul lui Curchi pentru o parte din Ghermănești & " \\
\hline 1727 & 1810 & mai & 26 & $\begin{array}{l}\text { Zapisul lui Hănganul pentru o parte din } \\
\text { Ghermănești }\end{array}$ & $"$ \\
\hline 1728 & - & - & - & Împărțeala Ghermăneștilor & " \\
\hline 1729 & 1812 & aprilie & 23 & Jalba Elenei pentru o parte din Ghermănești & $"$ \\
\hline 1730 & 1810 & mai & 26 & $\begin{array}{l}\text { Zapisul lui Ioniță Gori pentru o parte din } \\
\text { Ghermănești }\end{array}$ & $"$ \\
\hline 1731 & 1807 & aprilie & 1 & $\begin{array}{l}\text { Zapisul lui Ion Stratan pentru o parte din } \\
\text { Ghermănești }\end{array}$ & " \\
\hline 1732 & 1817 & decembrie & 10 & Jalba lui Stratan pentru o parte din Ghermănești & ” \\
\hline 1733 & 1813 & iulie & 4 & Chitanța lui Stratan pentru niște bani & 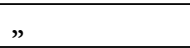 \\
\hline 1734 & 1811 & iunie & 14 & $\begin{array}{l}\text { Mărturia răzeșilor din Ghermănești pentru hotarele } \\
\text { moșiei }\end{array}$ & ” \\
\hline 1735 & 1816 & februarie & 9 & Mărturia pentru hotarele moșiei Siliștea & $"$ \\
\hline 1736 & - & - & - & Împărțeala moșiei Ghermăneștilor & ” \\
\hline 1737 & 1820 & iunie & 13 & $\begin{array}{l}\text { Zapisul lui „Don. Sinicliu” pentru o parte din } \\
\text { Stolniceni }\end{array}$ & $"$ \\
\hline 1738 & 1822 & octombrie & 20 & Contract de arendare a satului Ciuciuleni & 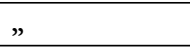 \\
\hline 1739 & 1823 & mai & 12 & Vechilime dată de Toader Arseni lui Mârzac & ” \\
\hline 1740 & 1817 & Mai & 20 & Jalba lui Gh. Tulbure p. moșia Sişcani & 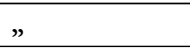 \\
\hline
\end{tabular}

${ }^{531} \mathrm{MEF}, \mathrm{IV}$, p. 32-34, nr. 7.

${ }^{532}$ În text: „Racova”.

${ }^{533}$ Boga (1929a), p. 61-63, nr. XXXVIII.

${ }^{534}$ Număr dublat.

${ }^{535}$ Doc. T. Mold., XII, p. 335-336, nr. 334. 


\begin{tabular}{|c|c|c|c|c|c|}
\hline 1741 & 1827 & - & - & Izvod de lemnele primite de Herșcu & ” \\
\hline 1742 & 1821 & octombrie & 2 & Scrisoarea lui <Ion> Bărcaru pentru niște bani & \\
\hline 1743 & 1654 & septembrie & 13 & $\begin{array}{l}\text { Cartea lui <Gheorghe Ștefan > voievod, dată lui } \\
\text { Darie }<\text { sulger }>\text {, pentru satul Bubuiogii, <ținutul } \\
\text { Orhei }>536\end{array}$ & copie \\
\hline 1744 & 1806 & martie & 2 & Jalba lui Darie către domn pentru moşiile lor & românesc \\
\hline 1745 & - & - & - & Spița neamului Darie & ” \\
\hline 1746 & 1645 & iulie & 24 & $\begin{array}{l}\text { Cartea lui Vasile voievod, dată în pricina moșiei } \\
\text { Drăgușeni } \\
537\end{array}$ & originalul și copie \\
\hline 1747 & 1817 & ianuarie & 6 & $\begin{array}{l}\text { Zapisul lui Horopcean pentru o parte din } \\
\text { Vărzărești }\end{array}$ & românesc \\
\hline 1748 & 1805 & martie & 26 & $\begin{array}{l}\text { Zapisul preotului Zupcu din Nisporeni pentru o } \\
\text { bucată de } \operatorname{loc}^{538}\end{array}$ & ” \\
\hline 1749 & 1805 & ianuarie & 26 & Zapisul lui Cârlig pentru o parte din Vărzărești ${ }^{539}$ & ” \\
\hline 1750 & 1801 & aprilie & 13 & Zapisul lui Țurcanu pentru o parte din Nisporeni & ” \\
\hline 1751 & 1800 & mai & 7 & $\begin{array}{l}\text { Zapisul lui Bolbocescu pentru o danie la mănăstirea } \\
\text { Vărzărești }\end{array}$ & ” \\
\hline 1752 & 1800 & mai & 5 & $\begin{array}{l}\text { Zapisul lui Țărnă pentru o danie mănăstirii } \\
\text { Vărzărești } \\
540\end{array}$ & ” \\
\hline 1753 & 1821 & august & 3 & $\begin{array}{l}\text { Zapisul lui „Hnidea” pentru o danie mănăstirii } \\
\text { Vărzărești }\end{array}$ & ” \\
\hline 1754 & 1806 & noiembrie & 18 & Scrisoarea Aniței Meleghi către Zoița Stratan ${ }^{541}$ & " \\
\hline 1755 & 1807 & iulie & 21 & Învoiala între soții Sovachi & " \\
\hline 1756 & 1794 & aprilie & 23 & Izvod de cele ce s-au dat de părinți lui Pavel ${ }^{542}$ & ” \\
\hline 1757 & 1818 & martie & 3 & $\begin{array}{l}\text { Izvod de cheltuielile făcute cu înmormîntare lui } \\
\text { Pavel }\end{array}$ & " \\
\hline 1758 & 1811 & februarie & 14 & $\begin{array}{l}\text { Zapisul lui Gavril pentru o parte din moșia } \\
\text { Copăceni }\end{array}$ & " \\
\hline 1759 & 1811 & februarie & 20 & $\begin{array}{l}\text { Zapisul lui Constantin pentru o parte din } \\
\text { Chiperceni }\end{array}$ & " \\
\hline 1760 & 1811 & martie & 21 & Izvod de stînjenii moșiei Chiperceni & 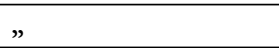 \\
\hline 1761 & - & - & - & Izvod de împărțeala unor moșii & românesc, deteriorat \\
\hline 1762 & 1807 & mai & 4 & Zapisul lui Ion Carp pentru o parte din Copăceni & " \\
\hline 1763 & 1767 & august & 17 & $\begin{array}{l}\text { Cartea lui Grigore Ghica voievod pentru moșia } \\
\text { Morozeni }{ }^{543}\end{array}$ & românesc \\
\hline 1764 & - & - & - & Jalba lui Andrei Cruce pentru moșia Morozeni & ” \\
\hline 1765 & - & - & - & Împărțeala între frații Rusu & ” \\
\hline 1766 & 1806 & septembrie & 2 & Zapisul lui Roșca pentru o parte din „Nainova” & " \\
\hline 1767 & 1806 & iunie & 6 & Zapisul lui Tulbure pentru o parte din Nisporeni & ” \\
\hline 1768 & 1794 & martie & 20 & $\begin{array}{l}\text { Izvod de banii dați pentru răscumpărarea moșiei } \\
\text { Vărzărești }\end{array}$ & ” \\
\hline 1769 & 1801 & iunie & 14 & Însemnare de vînzătorii unor părți din Vărzărești & " \\
\hline 1770 & - & - & - & Izvod de părțile ce alcătuiesc moșia Vărzărești & $"$ \\
\hline 1771 & 1827 & august & 27 & Scrisoarea lui Policarp Dioghenidi pentru niște bani & grecesc \\
\hline 1772 & 1822 & decembrie & 18 & Scrisoarea lui Atanasiu pentru niște bani & ” \\
\hline 1773 & 1815 & iunie & 6 & Răvașul lui Păun pentru niștre bani & $"$ \\
\hline 1774 & 1843 & iunie & 10 & Învoiala pentru împărțirea moșiei Hulboca & ” \\
\hline
\end{tabular}

\footnotetext{
${ }^{536}$ Boga (1930c), p. 139, nr. IV.

${ }^{537}$ Boga (1929d), p. 29-30, nr. XXVI; MEF, IV, p. 130-132, nr. 51.

${ }^{538}$ Boga (1929a), p. 26-27, nr. XIX; Doc. T. Mold., XII, p. 304, nr. 313.

${ }^{539}$ Doc. T.Mold., XII, p. 285-286, nr. 299.

${ }^{540}$ Boga (1929a), p. 25, nr. VII.

${ }^{541}$ Boga (1928b), p. 18-19, nr. XIII; Doc. T,.Mold. (2016), p. 11, nr. 3.

${ }^{542}$ Boga (1928a), p. 10, nr. IV.

${ }^{543}$ Doc. T,. Mold., IX, p. 188-189, nr. 162 (cu data corectă: „16 august 1766”).
} 


\begin{tabular}{|c|c|c|c|c|c|}
\hline 1775 & 1813 & octombrie & 22 & $\begin{array}{l}\text { Zapisul lui Pavel Nour pentru o parte din sus de } \\
\text { Călărași }\end{array}$ & " \\
\hline 1776 & 1833 & aprilie & 9 & $\begin{array}{l}\text { Hotărîrea Judecătoriei politicești a ținutului } \\
\text { „Ilfov” } 544 \text { pentru moșia „Meaza” }\end{array}$ & $"$ \\
\hline 1777 & $\frac{7211}{1702}$ & octombrie & 1 & Copia zapisului lui I. Sturza pentru moșia Culișanca & " \\
\hline 1778 & 1632 & august & 26 & $\begin{array}{l}\text { Copie după cartea lui Alexandru Iliaș voievod } \\
\text { pentru < Colișeuți }>545\end{array}$ & " \\
\hline 1779 & - & iunie & 22 & Scrisoare lui Bărce în chestiuni familiare & ” \\
\hline 1780 & 1593 & mai & 10 & $\begin{array}{l}\text { Copie. Zapisul <Irinei }{ }^{546} \text {, fata lui Avram, pentru } \\
\text { Culișăuca }{ }^{547}\end{array}$ & " \\
\hline 1781 & 1660 & martie & 22 & $\begin{array}{l}\text { Dania lui Ștefan voievod pentru mănăstirea Golia: } \\
\text { satele Clicicăuți și Milinești }\end{array}$ & $\begin{array}{l}\text { trad. și copie } \\
\text { slovenească }\end{array}$ \\
\hline 1782 & 1818 & iulie & 31 & $\begin{array}{l}\text { Zapisul lui Vasile Varzar pentru o parte din } \\
\text { „Copileni” }\end{array}$ & $\begin{array}{l}\text { românesc, cu trad. } \\
\text { rusească }\end{array}$ \\
\hline 1783 & 1822 & aprilie & 27 & Idem & 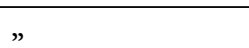 \\
\hline 1784 & 1823 & noiembrie & 13 & $\begin{array}{l}\text { Scrisoarea lui F. Varzar către C. Ivanovici pentru } \\
\text { moșia Micăuți }\end{array}$ & copie \\
\hline 1785 & 1834 & aprilie & 14 & Zapisul lui Carp pentru o parte din moșia Micăuţi. & românesc \\
\hline 1786 & 1802 & martie & 18 & Zapisul lui T. „Gogi” pentru o parte din Lipiceni & copie \\
\hline 1787 & 1800 & octombrie & 23 & Zapisul lui Hanu pentru o parte din Micăuți & 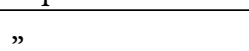 \\
\hline 1788 & 1821 & octombrie & 21 & Certificat dat de Gh. Hârjăn lui Ciobanu & rusesc \\
\hline $\begin{array}{c}1790 \\
549\end{array}$ & 1819 & august & 15 & Zapisul lui Hagi Gheorghe pentru moșia Nisporeni & românesc \\
\hline 1791 & 1814 & august & 17 & $\begin{array}{l}\text { Scrisoare lui Negruți către Gheorghe pentru } \\
\text { socoteli }\end{array}$ & $”$ \\
\hline 1792 & 1814 & martie & 26 & $\begin{array}{l}\text { Contract încheiat între M. Negruți și Ștefan } \\
\text { Solomon }\end{array}$ & " \\
\hline 1793 & - & - & - & $\begin{array}{l}\text { Notă de banii dați pentru arenda moșiei Moșana, } \\
<\text { din ținutul Hotin }>\end{array}$ & ” \\
\hline 1794 & 1667 & martie & 12 & $\begin{array}{l}\text { Copie. Cartea lui Alexandru Iliaș voievod, dată lui } \\
\text { Darie < fost mare spătar >, pentru moșia Pribeștii <și } \\
\text { pentru altele }>550\end{array}$ & ” \\
\hline 1795 & 1660 & martie & 10 & $\begin{array}{l}\text { Cartea lui Vasile voievod, dată fiului său Ștefan } \\
\text { voievod, prin care îi dăruește satul Bubuegii }\end{array}$ & ” \\
\hline 1796 & 1806 & mai & 26 & Jalba lui Darii către domn pentru moșia Bubuegii & ” \\
\hline 1797 & 1806 & august & 21 & Mărturia lui David pentru moșia Bubuegii & ” \\
\hline 1798 & 1806 & mai & 30 & Mărturia lui Mărdan pentru un act de danie & ” \\
\hline 1799 & 1814 & iunie & 30 & $\begin{array}{l}\text { Cartea Departamenului Pricinilor Streine pentru } \\
\text { moșia „Bardaiul” } 551\end{array}$ & $"$ \\
\hline 1800 & 1821 & aprilie & 23 & Contractul de arendare a moșiei Șișcani & ” \\
\hline 1801 & - & - & - & Chitanțe de sume diverse & ” \\
\hline 1802 & 1808 & ianuarie & 31 & Hotarnica moșiei Bravicea & ” \\
\hline 1803 & 1809 & mai & 19 & Porunca Sărdăriei pentru satul Bravicea & ” \\
\hline 1804 & 1779 & iulie & 20 & Zapisul lui Silion pentru o parte din Bravicea & 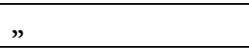 \\
\hline 1805 & 1815 & iunie & 29 & Porunca Sărdăriei pentru moșia Bravicea & ” \\
\hline 1806 & 1809 & iunie & 5 & Porunca Sărdăriei pentru moșia Bravicea & 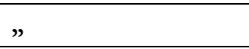 \\
\hline
\end{tabular}

${ }^{544}$ Greșit, la citire sau la dactilografiere.

${ }^{545}$ În text: „Călișanca”. Boga (1929f), p. 96-98, nr. XVI; MEF, III, p. 296-298, nr. 145.

${ }^{546}$ În text, greșit: „Ioanei”.

${ }^{547}$ Boga (1932a), p. 143, nr. I; MEF, I, p. 151-152, nr. 64.

${ }^{548}$ Iorga (1920), p. 82; MEF, IV, p. 299-304, nr. 135; Zahariuc \& Marinescu (2008), p. 26-30 (orig. din arhiva mănăstirii Vatoped, Muntele Athos).

${ }^{549}$ Numărul 1789 lipsește.

${ }^{550}$ Boga (1930c), p. $158-160$, nr. XXII.

${ }^{551}$ Probabil: „Bardar” (ținutul Orhei). 


\begin{tabular}{|c|c|c|c|c|c|}
\hline 1807 & 1809 & februarie & 18 & Jalba lui Lupul în pricina moșiei Bravicea & ” \\
\hline 1808 & 1839 & martie & 10 & Mărturia hotarnică a moșiei Meleșeni & ” \\
\hline 1809 & 1843 & martie & 31 & $\begin{array}{l}\text { Scrisoarea mitropolitului Grigore Irinopoleos către } \\
\text { sătenii din Cărpineni } 552\end{array}$ & " \\
\hline 1810 & 1636 & aprilie & 4 & $\begin{array}{l}\text { Cartea lui Petre < pîrcălabul }>^{553} \text { pentru moșia } \\
\text { Morozeni }\end{array}$ & ” \\
\hline 1811 & 1732 & martie & 30 & $\begin{array}{l}\text { Cartea lui Grigore Ghica voievod pentru moșia } \\
\text { Isacova }^{555}\end{array}$ & " \\
\hline 1812 & 1812 & martie & 2 & Chitanța pentru două acte & ” \\
\hline 1813 & 1813 & ianuarie & 27 & Zapisul lui Tăbârcă pentru moșia Isacova & ” \\
\hline 1814 & 1724 & septembrie & 24 & $\begin{array}{l}\text { Cartea lui Mihai Racoviță voievod pentru moșia } \\
\text { Morozeni }\end{array}$ & " \\
\hline 1815 & 1794 & aprilie & 20 & Zapis pentru arendarea moșiei Isacova & ” \\
\hline 1816 & 1818 & august & 17 & $\begin{array}{l}\text { Mărturia lui Petre vornicul pentru Frăsuleni, <din } \\
\text { ținutul Iași> }\end{array}$ & copie \\
\hline 1817 & 1824 & noiembrie & 1 & Mărturia răzeșilor pentru satul Leușeni & ” \\
\hline $\begin{array}{c}1819 \\
557\end{array}$ & 1814 & februarie & 1 & Scrisoare către Gavril Stroici pentru bani & românesc \\
\hline 1820 & 1785 & martie & 20 & Spița răzeșilor din Isacova & ” \\
\hline 1821 & 1811 & ianuarie & 23 & $\begin{array}{l}\text { Cartea Divanului Cnejiei Moldovei pentru moșia } \\
\text { Mărtinești }\end{array}$ & $”$ \\
\hline 1822 & 1816 & iunie & 17 & $\begin{array}{l}\text { Hotărîrea Departamentului I-iu în pricina lui Darie } \\
\text { Cazacul }\end{array}$ & ” \\
\hline 1823 & 1835 & martie & 28 & $\begin{array}{l}\text { Învoiala între Elisaveta Chicerescu şi Zamfira } \\
\text { Chicerescu }\end{array}$ & ” \\
\hline 1824 & - & - & - & Contract de arendare a moșiei Peresecina & ” \\
\hline 1825 & 1790 & martie & 8 & $\begin{array}{l}\text { Zapisul lui Vasile <și a lui > Petre Caba pentru o } \\
\text { parte din Orzești }\end{array}$ & ” \\
\hline 1826 & 1803 & noiembrie & 22 & Hotarnica moșiei Mărtinești & ” \\
\hline 1827 & 1810 & februarieie & 15 & $\begin{array}{l}\text { Zapisul lui Darie Cazacul pentru o parte din } \\
\text { „Ghirești” }\end{array}$ & " \\
\hline 1828 & 1822 & octombrie & 11 & Izvodul documentelor moșiei Ghirești & " \\
\hline 1829 & 1810 & decembrie & 5 & Alegerea părților moșiei Ghirești & ” \\
\hline 1830 & 1802 & iulie & 8 & Zapisul lui Ipati pentru 20 lei împrumutați & ” \\
\hline 1831 & 1817 & februarie & 11 & Lista lui Benedict egumenul & " \\
\hline 1832 & 1576 & aprilie & 17 & $\begin{array}{l}\text { Suret. Cartea lui Petru voievod dată lui Grozav } \\
\text { pentru moșia Negăuți, < din ținutul Hotin> }>558\end{array}$ & copie românească \\
\hline 1833 & 1779 & ianuarie & 20 & Cartea de judecată în pricina Serghieștilor & românesc \\
\hline 1834 & - & - & - & Polițe semnate de diverși (17 bucăți) & ” \\
\hline 1835 & $\langle 1770\rangle$ & noiembrie & 30 & Spița neamului „Părnova” & $"$ \\
\hline 1836 & 1821 & februarie & 1 & Vichilime dată de Hasan „Babi” lui Gh. Vicol & ” \\
\hline 1837 & - & - & - & Catastif de diverse cheltuieli & ” \\
\hline 1838 & 1832 & martie & 21 & Contract de arendare a moșiei Milești & " \\
\hline 1839 & 1819 & Iunie & 18 & Scrisori grecești ale lui Pavlu (3 bucăți) & grecești \\
\hline 1840 & 1717 & decembrie & 7 & $\begin{array}{l}\text { Zapisul lui Bosoc pentru o parte din moșia } \\
\text { Condrești }\end{array}$ & românesc \\
\hline 1841 & 1838 & ianuarie & 23 & Cartea Divanului pentru pricina lui Neculai Bucur & " \\
\hline
\end{tabular}

\footnotetext{
${ }^{552}$ Boga (1928b), p. 140-141, nr. CXCVIII.

553 În text: „Parașul”.

${ }^{554}$ MEF, III, p. 356-358, nr. 170 (cu data de an corectă: „1636 <7144>”).

${ }^{555}$ Boga (1930b), p. 478-479, nr. II; MEF, VIII, p. 110-111, nr. 79.

${ }^{556}$ MEF, VIII, p. 80-81, nr. 46 (cu data de an corectă: „1723”).

${ }^{557}$ Numărul 1818 lipsește.

${ }^{558}$ Boga (1929c), p. 24-26, nr. XVIII; MEF, I, p. 87-88, nr. 33.
} 


\begin{tabular}{|c|c|c|c|c|c|}
\hline 1842 & 1778 & martie & 10 & Mărturia hotarnică a moșiei Codrești ${ }^{559}$ & $"$ \\
\hline 1843 & 1794 & noiembrie & 30 & $\begin{array}{l}\text { Zapisul lui Ion Negură pentru o parte din } \\
\text { Codrești }^{560}\end{array}$ & " \\
\hline 1844 & 1795 & august & 20 & Zapisul lui Ion Negură pentru o parte din Codrești & ” \\
\hline 1845 & 1805 & iulie & 26 & $\begin{array}{l}\text { Raportul Divanului Moldovei în pricina }<\text { pentru } \\
\text { moșia Condrești }>561\end{array}$ & " \\
\hline 1846 & 1750 & februarie & 1 & $\begin{array}{l}\text { Zapisul Ștefanei prin care vinde o parte din } \\
<\text { bătrînul Condre }>562\end{array}$ & românesc, cu trad. \\
\hline 1847 & 1750 & februarie & 24 & Zapisul $<$ Năstas $>^{563}$, idem $^{564}$ & " \\
\hline 1848 & 1729 & septembrie & 4 & Zapisul dat lui Furculiță pentru o parte din Codreni & ” \\
\hline 1849 & 1782 & mai & 20 & Zapisul Nastasiei pentru o parte din Codreni & " \\
\hline 1850 & 1822 & aprilie & 23 & Zapisul lui Popa pentru o parte din Onișcani & ” \\
\hline 1851 & 1821 & decembrie & 15 & Mărturia dată lui Constantin Vârlanu & ” \\
\hline 1852 & 1826 & ianuarie & - & Vichilimea dată de Varlaam lui Sevanos & rusesc \\
\hline 1853 & 1819 & - & - & Spița neamului Codreanu & românesc \\
\hline 1854 & 1837 & septembrie & 13 & Învoiala între Catinca Roșca și Criste & ” \\
\hline 1855 & 1780 & decembrie & 4 & Hotarnica moșiei Onești, <din ținutul Orhei ${ }^{565}$ & " \\
\hline 1856 & 1808 & ianuarie & 22 & Învoiala între Lupul Roset și răzeșii din Onești & " \\
\hline 1857 & 1811 & mai & 20 & Mărturia hotarnică pentru moșia „Cărăbășeni” ${ }^{266}$ & " \\
\hline 1858 & - & - & - & Cererea Ancuței Suhanova pentru moșia Onișcani & \# \\
\hline 1859 & 1666 & iulie & 30 & $\begin{array}{l}\text { Suret. Cartea lui Alexandru Ilieș voievod, dată } \\
\text { mănăstirii Golia, pentru satele <Milinești și } \\
\text { Clicicăuți, din ținutul Hotin> }{ }^{567}\end{array}$ & copie \\
\hline 1860 & $<1630>$ & septembrie & $\langle 9\rangle$ & $\begin{array}{l}\text { Suret. Cartea lui Moise voievod, dată lui Gavrilaș } \\
<\text { fost mare vornic >, pentru satul Rășcăuți, < din } \\
\text { ținutul Hotin }>568\end{array}$ & $\begin{array}{l}\text { românesc, cu trad. } \\
\text { rusească }\end{array}$ \\
\hline 1861 & 1814 & anuarie & 4 & $\begin{array}{l}\text { Zapisul lui Gheorghe Grigoriu prin care vinde } \\
\text { Prihorodul, <din ținutul Hotin> }\end{array}$ & $"$ \\
\hline 1862 & 1777 & mai & 4 & $\begin{array}{l}\text { Ordinul Comandamentului rusesc de a se da satul } \\
\text { Cotiujenii }\end{array}$ & $"$ \\
\hline 1863 & 1810 & mai & 7 & Porunca Divanului către Pîrcălăbia Hotin & $"$ \\
\hline 1864 & - & - & - & Registru de socoteli în grecește & grecesc \\
\hline 1865 & 1420 & aprilie & 25 & $\begin{array}{l}\text { Suret. Cartea lui Alex. cel Bun dată lui Vană vornic } \\
\text { prin care îi dăruiește satele: Cornești, Miclăușești, } \\
\text { Lozova, Secăreni, Vorniceni, Dumești, Tigănești, } \\
\text { Lăvrești, Sadova și Homicești }{ }^{569}\end{array}$ & $"$ \\
\hline 1866 & 1775 & august & 17 & $\begin{array}{l}\text { Cartea lui Grigore Ghica voievod, dată lui Iordache } \\
\text { Cantacuzino, pentru satele din Hotin }\end{array}$ & copie românească \\
\hline
\end{tabular}

\footnotetext{
${ }^{559}$ Boga (1938a), p. 78-81, nr. XXX (cu data greșită: „10 mai $1770<7278>$ ); Doc. T,. Mold., X, p. 80-83, nr. 52 (cu data: „10 martie 1778”).

${ }^{560}$ Doc. T,.Mold., XI, p. 200-201, nr. 146.

${ }^{561}$ Rezumat neterminat, completat după Doc. T. Mold., XII, p. 322-324, nr. 326.

562 În text: „Codreni”. Vezi rezumatul următor, nr. 1847.

563 În text: „Nastasia”.

${ }^{564}$ MEF, VIII, p. 218, nr. 177 (Năstas, Ștefana și alte rude ale lor, copiii și nepoții lui Pănteleiu din Onășcani, vînd o jumătate din bătrînul Condre; nu este precizat satul, însă probabil că este vorba de Onășcani).

${ }^{565}$ Boga (1938a), p. 102-106, nr. XXXVIII (cu data de zi: „23”). Mărturia hotarnică are data: 4 decembrie, iar data de 23 decembrie a fost adăugată la o completare, semnată de Constantin Roseti spătar și de Șărbănachi comis. Doc. T,. Mold., X, p. 105-108, nr. 73 (cu data: „4 decembrie 1780”).

${ }^{566}$ Poate „Caracușeni”.

${ }^{567}$ În text, greșit: „Milești”. Boga (1930c), p. 157-158, nr. XXI.

${ }^{568}$ În text, data de an și de zi a actului este greșită: „1630 septembrie 2”. Boga (1929d), p. 12-13, nr. IX (cu data corectă: „9 septembrie 1630"); MEF, III, p. 248-249, nr. 122.

${ }^{569}$ Boga (1929b), p. 3-4, nr. I; MEF, I, p. 37-40, nr. 5.
} 


\begin{tabular}{|c|c|c|c|c|c|}
\hline 1867 & 1654 & iulie & 3 & $\begin{array}{l}\text { Cartea lui Gheorghe Ștefan voievod, dată lui } \\
<\text { Alexandru și lui Mironaș și altor frați ai lor, fiii lui } \\
\text { Costin hatman>, pentru satul <Clicicăuți, din } \\
\text { ținutul Hotin }>570\end{array}$ & " \\
\hline 1868 & 1822 & august & 3 & $\begin{array}{l}\text { Mărturia lui Nicanor Cotelevschi pentru o casă din } \\
\text { Chișinău }\end{array}$ & românesc \\
\hline 1869 & 1631 & martie & 18 & $\begin{array}{l}\text { Suret. Cartea lui Moise voievod, dată lui Tudori } \\
\text { pîrcălab, pentru satul Clișcăuți, < din ținutul } \\
\text { Hotin }>571\end{array}$ & " \\
\hline 1870 & 1797 & septembrie & - & $\begin{array}{l}\text { Contract pentru arenda ce au de plătit orăşenii } \\
\text { Chișinăului }\end{array}$ & copie \\
\hline 1871 & 1773 & septembrie & 23 & $\begin{array}{l}\text { Cartea lui Alexandru Calimah voievod, dată pentru } \\
\text { tîrgul Chișinăului }\end{array}$ & românesc, copie \\
\hline 1872 & 1838 & mai & 21 & Vechilime dată de Episcopia Hușului lui Culschi & românesc \\
\hline 1873 & 1820 & aprilie & 21 & Dania Mariuței, $<$ fiica lui Ioniță Peticu $>^{572}$ & ” \\
\hline 1874 & 1823 & iunie & 12 & $\begin{array}{l}\text { Zapisul lui Istrate pentru o parte din Balotina, }<\text { din } \\
\text { ținutul Iași> }\end{array}$ & ” \\
\hline 1875 & 1824 & iunie & 3 & Mărturia lui T. Botescu pentru moșia Balotina & ” \\
\hline 1876 & - & - & - & Planul moșiei Horodca, < din ținutul Lăpușna > & rusesc \\
\hline 1877 & 1817 & decembrie & 4 & $\begin{array}{l}\text { Scrisoarea lui < Iordachi> Milo către Matei } \\
\text { Crupenschi }^{573}\end{array}$ & românesc \\
\hline 1878 & 1818 & februarie & 2 & $\begin{array}{l}\text { Răspunsul lui <Matei }>\text { Crupenschi la scrisoarea lui } \\
<\text { Iordachi }>\text { Milo }\end{array}$ & ” \\
\hline 1879 & 1784 & decembrie & 22 & Mărturia răzeșilor pentru un iaz la Hâncești & ” \\
\hline 1880 & 1795 & mai & 5 & $\begin{array}{l}\text { Mărturia vornicului din Milești pentru hotarele } \\
\text { satului }\end{array}$ & ” \\
\hline 1881 & 1824 & februarie & 7 & Răvaș de cununie, tipărit & ” \\
\hline 1882 & 1818 & ianuarie & 28 & Scrisoarea lui Vasile Roset în chestia unor moşii ${ }^{575}$ & " \\
\hline 1883 & 1818 & Iunie & 5 & Zapisul Mariei serdăreasa pentru moșia Cobâlca & ” \\
\hline 1884 & - & - & - & Diverse chitanțe și polițe rusești (43 bucăți) & rusesc \\
\hline 1885 & 1787 & ianuarie & 4 & $\begin{array}{l}\text { Zapisul răzeșilor din Chiperceni pentru o parte de } \\
\text { moșie }\end{array}$ & românesc \\
\hline 1886 & 1840 & august & 7 & Chitanța Ecaterinei Balș pentru 4.000 ruble & rusesc \\
\hline 1887 & 1828 & martie & 21 & $\begin{array}{l}\text { Adresa Comisiei hotărîturilor către Judecătoria } \\
\text { ținutului pentru moșia Bravicea }\end{array}$ & românesc \\
\hline 1888 & 1802 & octombrie & 16 & Învoiala între răzeșii Galeată pentru o parte de loc & $"$ \\
\hline 1889 & - & - & - & Spița neamului Galeată & ” \\
\hline 1890 & 1852 & ianuarie & 26 & Jalba lui Ștefan Agache pentru moșia Isnovațul & 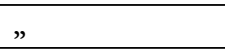 \\
\hline 1891 & 1852 & martie & 28 & Porunca Sărdăriei către Ioniță Pârlea & " \\
\hline 1892 & 1811 & iulie & 1 & Spița neamului Terciul pentru moșia Isnovățul & ” \\
\hline 1893 & 1852 & mai & 18 & $\begin{array}{l}\text { Zapisul lui Petrașcu pentru o parte din moșia } \\
\text { Dumbravița }\end{array}$ & $"$ \\
\hline 1894 & 1812 & iunie & 12 & Scrisoarea lui Vicol pentru o parte din moșie & ” \\
\hline 1895 & 1813 & iulie & 12 & $\begin{array}{l}\text { Hotărîrea Departamentului I-iu pentru moșia } \\
\text { Suruceni }\end{array}$ & $”$ \\
\hline 1896 & 1818 & septembrie & 12 & Zapisul lui Chiriță pentru o parte din Suruceni & ” \\
\hline 1897 & 1818 & ianuarie & 24 & $\begin{array}{l}\text { Zapisul lui Alexandru Suruceanu pentru o parte } \\
\text { din Suruceni }\end{array}$ & ” \\
\hline 1898 & 1818 & februarie & 8 & Listă de stînjeni din bătrînul Harca de la Suruceni & ” \\
\hline
\end{tabular}

${ }^{570}$ În text, greșit: „Gheicauți”. Boga (1930c), p. 136-137, nr. II (carte de judecată domnească între fiii hatmanului Iancu Costin și mănăstirea Golia).

${ }^{571}$ Boga (1929d), p. 13, nr. X; MEF, III, p. 267-268, nr. 131.

${ }^{572}$ In text: „Petcu”. Boga (1929a), p. 52-53, nr. XXX.

${ }^{573}$ Boga (1928b), p. 40-41, nr. XLVIII.

${ }^{574}$ Boga (1928b), p. 41-44, nr. LI.

${ }^{575}$ Boga (1928b), p. 41-42, nr. L. 


\begin{tabular}{|c|c|c|c|c|c|}
\hline 1899 & 1812 & august & 3 & $\begin{array}{l}\text { Cartea Divanului Moldovei pentru moșia Susleni a } \\
\text { lui P. Măcărescu }\end{array}$ & $"$ \\
\hline 1900 & 1814 & decembrie & 16 & $\begin{array}{l}\text { Cartea Departamentului I-iu în pricina lui T. } \\
\text { Măcărescu }\end{array}$ & $"$ \\
\hline 1901 & 1783 & mai & 22 & Zapisul lui Ursachi pentru moșia Susleni & orig. și copie \\
\hline 1902 & 1777 & martie & 1 & Zapisul lui Trohin Burduja pentru moşia Susleni & ” \\
\hline 1903 & 1779 & iulie & 1 & Zapisul lui Epati pentru o parte din Susleni & ” \\
\hline 1904 & 1773 & februarie & 2 & Zapisul lui Țapordei pentru o parte din Susleni & 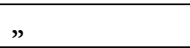 \\
\hline 1905 & 1785 & ianuarie & 8 & $\begin{array}{l}\text { Zapisul lui Ștefan Popescu pentru o parte din } \\
\text { Susleni }\end{array}$ & " \\
\hline 1906 & 1820 & octombrie & 27 & $\begin{array}{l}\text { Hotărîrea Judecătoriei policești a Basarabiei în } \\
\text { pricina lui T. Măcărescu }\end{array}$ & " \\
\hline 1907 & 1793 & septembrie & 13 & $\begin{array}{l}\text { Cartea lui Mihai Suțul voievod, dată lui Botescu, } \\
\text { pentru Susleni }\end{array}$ & trad. rusească \\
\hline 1908 & 1835 & Mai & 10 & Hotărîrea în chestia delegației plecată la Petersburg & rusesc \\
\hline 1909 & 1820 & noiembrie & 1 & Scrisoarea lui Sandul Sturza în chestiuni comerciale & grecesc \\
\hline 1910 & 1828 & octombrie & 12 & Mărturia lui C. Sturza pentru moșia Cobușca & românesc \\
\hline 1911 & 1819 & decembrie & 15 & $\begin{array}{l}\text { Cartea lui Grigorie <Irinopoleos> arhiepiscopul } \\
\text { pentru moșia Cobușca }\end{array}$ & ” \\
\hline 1912 & 1833 & decembrie & 22 & Învoiala între răzeșii din moșia Broscăuți & ” \\
\hline 1913 & 1834 & martie & 2 & $\begin{array}{l}\text { Hotărîrea Judecătoriei Dorohoiului pentru părțile } \\
\text { din Broscăuți }\end{array}$ & ” \\
\hline 1914 & 1831 & aprilie & 10 & Scrisoare către Plaghino în chestia moșiei Broscauți & grecesc \\
\hline 1915 & 1831 & aprilie & 15 & Scrisoarea lui Plaghino în chestia moșiei Broscăuți & $"$ \\
\hline 1916 & 1816 & ianuarie & 11 & Chitanța lui Polihroni Dimitriu pentru niște bani & ” \\
\hline 1917 & 1817 & - & - & $\begin{array}{l}\text { Adeverința lui Măcărescu și alți boieri pentru } \\
\text { Dimitriu }\end{array}$ & românesc \\
\hline 1918 & 1825 & aprilie & 23 & Contract de arendare a moșiei Siliștea & grecesc \\
\hline 1919 & 1826 & august & 31 & $\begin{array}{l}\text { Hotărîrea Adunării Nobilimii în chestia lui } \\
\text { Dimitriu }\end{array}$ & românesc \\
\hline 1920 & 1642 & aprilie & 5 & $\begin{array}{l}\text { Copie. Cartea lui Vasilie voievod, dată lui <Mihail > } \\
\text { Săpoteanu <jitnicer }>\text {, pentru satul Tuzora, <pe Bâc, } \\
\text { și pentru alte sate }>576\end{array}$ & ” \\
\hline 1921 & 1803 & martie & 5 & $\begin{array}{l}\text { Constantin Alexandru Moruzi voievod pentru } \\
\text { hotarele satului Bărăiacul, < <in ținutul Orhei > }{ }^{577}\end{array}$ & $"$ \\
\hline 1922 & 1803 & martie & 13 & Cartea lui Alexandru Moruzi pentru moșia Deșcu & ” \\
\hline 1923 & 1803 & iulie & 7 & Porunca Sărdăriei de Orheiu pentru moșia Deșcu & ” \\
\hline 1924 & 1762 & iulie & 25 & $\begin{array}{l}\text { Hotarnica moșiei Nișcanilor, <din ținutul } \\
\text { Orhei }>578\end{array}$ & $"$ \\
\hline 1925 & 1808 & iunie & 29 & Porunca Sărdăriei pentru moșia Deșcu & ” \\
\hline 1926 & 1792 & decembrie & 23 & Învoiala între Neculai Bacalu și Pleșca & ” \\
\hline 1927 & 1799 & august & 7 & $\begin{array}{l}\text { Zapisul lui <Drența }{ }^{579} \text { pentru o parte din moșia } \\
\text { Deșca }^{580}\end{array}$ & $"$ \\
\hline 1928 & 1793 & mai & 1 & $\begin{array}{l}\text { Mărturia dată lui Pleșca pentru partea lui din } \\
\text { moșie }^{581}\end{array}$ & ” \\
\hline 1929 & 1803 & octombrie & 18 & $\begin{array}{l}\text { Cartea lui Alexandru Suțul < voievod> pentru } \\
\text { moșia Bărăiacul }^{582}\end{array}$ & $"$ \\
\hline 1930 & 1746 & noiembrie & 8 & $\begin{array}{l}\text { Cartea lui <Constantin }>\text { Nicolae voievod } \\
<\text { Mavrocordat }>\text { pentru datoriile lui Brahă }\end{array}$ & $"$ \\
\hline
\end{tabular}

${ }^{576}$ Boga (1929d), p. 24-27, nr. XXIII; MEF, IV, p. 41-47, nr. 11.

${ }^{577}$ Doc. T. Mold., XII, p. 136-137, nr. 115.

${ }^{578}$ Boga (1938a), p. 56-58, nr. XXIV.

579 În text: „Franta”.

${ }^{580}$ Doc. T,.Mold., XI, p. 317-318, nr. 253.

${ }^{581}$ Doc. T. Mold., XI, p. 133-134, nr. 92.

${ }^{582}$ Doc. T..Mold., XII, p. 209-210, nr. 207. 


\begin{tabular}{|c|c|c|c|c|c|}
\hline 1931 & 1796 & mai & 17 & Porunca Sărdăriei pentru datoriile lui Brahă & ” \\
\hline 1932 & 1809 & iunie & 4 & Zapisul Saftei pentru niște datorii & ” \\
\hline 1933 & 1806 & mai & 16 & $\begin{array}{l}\text { Zapisul lui Simion pentru o parte din moșia } \\
\text { Cornești }\end{array}$ & " \\
\hline 1934 & 1777 & mai & 12 & $\begin{array}{l}\text { Învoiala lui Constantin Râșcanu pentru hotarele } \\
\text { moșiei Tuzora }\end{array}$ & $"$ \\
\hline 1935 & 1779 & iulie & 6 & Hotarnica moșiei <Vărca, din ținutul Orhei ${ }^{583}$ & " \\
\hline 1936 & 1790 & iunie & 9 & Cartea Divanului Moldovei pentru moșia Dișcu & ” \\
\hline 1937 & 1804 & mai & 10 & Hotărîrea în pricina hotarelor moșiei Dișcu & ” \\
\hline 1938 & 1804 & - & - & Porunca Sărdăriei în pricina hotarelor moșiei Dișcu & ” \\
\hline 1939 & 1806 & august & 1 & Mărturia răzeșilor pentru hotarele moșiei Dișcu & ” \\
\hline 1940 & 1790 & - & 27 & Cartea Divanului pentru hotarele moșiei Cornești & ” \\
\hline 1941 & 1788 & iunie & 21 & Mărturia hotarnică a moșiei Dișcu ${ }^{584}$ & ” \\
\hline 1942 & 1790 & august & 29 & $\begin{array}{l}\text { Mărturia dată lui Simion Popa pentru hotarele } \\
\text { moșiei Dișcu }\end{array}$ & $"$ \\
\hline 1943 & 1817 & mai & 30 & $\begin{array}{l}\text { Hotărîrea Judecătoriei ținutului pentru moșia } \\
\text { Dișcu }\end{array}$ & ” \\
\hline 1944 & 1827 & ianuarie & - & $\begin{array}{l}\text { Raportul ocolașului pentru o bucată de loc din } \\
\text { Vălcineț, <din ținutul Hotin> }\end{array}$ & ” \\
\hline 1945 & - & - & - & Hotarnica moșiei „Perenta” ${ }^{586}$ & ” \\
\hline 1946 & 1815 & noiembrie & 10 & $\begin{array}{l}\text { Raport către Isprăvnicia Orhei pentru hotareșe } \\
\text { moșiei Frumușica }\end{array}$ & " \\
\hline 1947 & 1814 & iunie & 24 & $\begin{array}{l}\text { Hotărîrea Departamentului I-iu al Basarabiei în } \\
\text { pricina răzvrătirii tîrgoveților din Telenești } \\
\text { 587 }\end{array}$ & " \\
\hline 1948 & 1816 & aprilie & 23 & $\begin{array}{l}\text { Zapisul lui Marcul Sârbu pentru o parte din } \\
\text { Durlești }\end{array}$ & $"$ \\
\hline 1949 & - & - & - & $\begin{array}{l}\text { Zapisul lui Andrei Tiron pentru o parte din } \\
\text { Durlești }\end{array}$ & deteriorat \\
\hline 1950 & 1817 & aprilie & 23 & Zapisullui Marcu pentru o parte din Piciorogani & românesc \\
\hline 1951 & 1812 & aprilie & 23 & Zapisul lui Chiriac pentru o parte din Durlești & 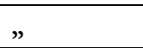 \\
\hline 1952 & 1816 & martie & 12 & Hotarnica moșiei Bogzăștii & 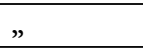 \\
\hline 1953 & 1819 & august & 13 & $\begin{array}{l}\text { Hotărîrea Judecătoriei Politicești a Basarabiei în } \\
\text { pricina lui „Brăun” }\end{array}$ & ” \\
\hline 1954 & 1819 & aprilie & 23 & $\begin{array}{l}\text { Mărturia răzeșilor din moșia Colunești, <din } \\
\text { ținutul Iași> }\end{array}$ & ” \\
\hline 1955 & 1822 & martie & 26 & Scrisoarea către Munteanu in pricina unor bani & ” \\
\hline 1956 & 1815 & iulie & 8 & $\begin{array}{l}\text { Scrisoarea lui Jărdan <către Manoli Petică > în } \\
\text { chestia unei moșii }\end{array}$ & $"$ \\
\hline 1957 & 1811 & noiembrie & 16 & $\begin{array}{l}\text { Scrisoarea <lui Isaia Surucian pitar > către } \\
<\text { Manolache Dimache }>{ }^{589} \text { pentru moșia Popești }{ }^{590}\end{array}$ & " \\
\hline 1958 & 1816 & martie & 1 & $\begin{array}{l}\text { Zapisul dat lui Panaiti Catargiu pentru moșia } \\
<\text { Hănăseni }>591\end{array}$ & ” \\
\hline 1959 & - & - & - & $\begin{array}{l}\text { Diverse chitanțe, polițe, note și socoteli, românești, } \\
\text { rusesști, grecești și evreiești ( } 137 \text { hîrtii, precum și } 7 \\
\text { răboji) }\end{array}$ & ” \\
\hline
\end{tabular}

\footnotetext{
${ }^{583}$ În text: „Verbea”. Boga (1938a), p. 94-97, nr. XXXV.

${ }^{584}$ Doc. T. Mold., XI, p. 60-61, nr. 15.

${ }^{585}$ Doc. T,.Mold., XI, p. 76-77, nr. 33.

${ }^{586}$ Poate „Pererita” (ținutul Hotin).

${ }^{587}$ Despre răzvrătirea locuitorilor din Telenești, vezi și informațiile scoase de Costăchescu (1930), p. 37-44, din arhiva lui

Paul Gore de la ANI, Doc..

${ }^{588}$ Boga (1928b), p. 31-32, nr. XXXV (cu data de zi: „„”).

${ }^{589}$ În text, greșit: „Alecu”.

${ }^{590}$ Boga (1928b), p. 21-22, nr. XIX.

${ }^{591}$ În text: „Heineșani”.
} 


\begin{tabular}{|c|c|c|c|c|c|}
\hline 1960 & 1805 & mai & 15 & $\begin{array}{l}\text { Izvod de zestre ce dă fiicei sale, }<\text { Apostolachi }>^{592} \\
\text { Stavilă } 593\end{array}$ & ” \\
\hline 1961 & 1813 & august & 25 & Cererea lui Iordache Roset pentru zestrea soției sale & ” \\
\hline 1962 & 1808 & februarie & 26 & Jalba lui I. Calmuțchi către Divan pentru zestre & ” \\
\hline 1963 & 1824 & - & - & Scrisoarea lui Crupenschi în chestii bănești & ” \\
\hline 1964 & 1820 & - & - & Sărdăria de Orhei către Alexandru Tobultco & ” \\
\hline 1965 & 1820 & - & - & Porunca către vornicul din satul Găureni & $"$ \\
\hline 1966 & 1809 & ianuarie & 3 & $\begin{array}{l}\text { Copie. Zapisul unor răzeși din Văsieni pentru o } \\
\text { bucată de loc } \\
594\end{array}$ & $"$ \\
\hline 1967 & 1817 & ianuarie & 18 & $\begin{array}{l}\text { Mărturia Nedelei Căldărari pentru o casă din } \\
\text { Chișinău }\end{array}$ & ” \\
\hline 1968 & 1820 & aprilie & 26 & Învoiala între Nicoale Ion și Constantin Papadopol & grecesc \\
\hline 1969 & 1824 & - & - & Socoteala lui Fotiadi asupra lui Dioghenide & $”$ \\
\hline 1970 & 1831 & august & 31 & Contract de arendare a moșiei Calinești & românesc \\
\hline 1971 & 1821 & mai & 22 & Diploma de noblețe a familiei poloneze Ruthovschi & polonez \\
\hline 1972 & 1821 & - & - & Testamentul lui Ivanovici & 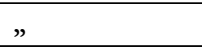 \\
\hline 1973 & 1821 & februarie & - & Extras de $<$ certificat de $>$ naștere a lui Ivan Ignatin ${ }^{595}$ & rusesc \\
\hline 1974 & 1821 & aprilie & 2 & Diploma de noblețe a lui Gheorghe Ignatin & latin \\
\hline 1975 & 1821 & februarie & 6 & Testamentul lui Gheorghe Ignatin & ” \\
\hline 1976 & 1651 & mai & 5 & Zapisul lui Gore pentru o parte din Bilăuți ${ }^{596}$ & românesc \\
\hline 1977 & 1646 & iunie & 26 & Zapisul lui Cazacul pentru o parte din Săngereni ${ }^{597}$ & " \\
\hline 1978 & 1658 & Iulie & 14 & $\begin{array}{l}\text { Cartea lui Gheorghe Ghica voievod pentru satul } \\
\text { Forosna }\end{array}$ & $"$ \\
\hline 1979 & 1646 & iunie & 22 & Zapisul lui Mirea pentru o parte din Săngereni ${ }^{599}$ & ” \\
\hline 1980 & - & aprilie & 27 & $\begin{array}{l}\text { Zapisul lui popa „Gubca” pentru o parte din } \\
\text { Săngereni }\end{array}$ & veacul XVI ${ }^{600}$ \\
\hline 1981 & - & - & - & Zapisul Gava pentru o parte din Săngereni & românesc \\
\hline 1982 & 1646 & februarie & 19 & $\begin{array}{l}\text { Cartea lui Vasilie voievod, dată lui Balan <comis >, } \\
\text { pentru satul Săngereni }\end{array}$ & " \\
\hline 1983 & 1645 & mai & 20 & Schimb între Cazacul, Gavril Hajdău și alții ${ }^{602}$ & " \\
\hline 1984 & 1669 & februarie & 20 & $\begin{array}{l}\text { Cartea lui Duca voievod pentru hotarele satului } \\
\text { Forosna, }<\text { din ținutul Hotin }>603\end{array}$ & $"$ \\
\hline 1985 & 1669 & februarie & 8 & $\begin{array}{l}\text { Cartea lui Duca voievod pentru hotarele satului } \\
\text { Forosna, }<\text { din ținutul Hotin }>604\end{array}$ & ” \\
\hline 1986 & 1647 & mai & 3 & Catastiful comisului Bălan & ” \\
\hline 1987 & 1646 & iulie & 2 & Schimb între Cazacul, Gavril Hajdău și alții & ” \\
\hline 1988 & 1645 & mai & 16 & Zapisul lui Necoară pentru o parte din Forosna ${ }^{605}$ & ” \\
\hline
\end{tabular}

${ }^{592}$ În text greșit: „Anastas(ie)”.

${ }^{593}$ Boga (1928a), p. 15-17, nr. IX (cu data de lună: „martie”; zestrea este dată de epitropul casei răposatului medelnicer Apostolachi Stavilă, marele vistiernic Grigoraș Sturza).

${ }^{594}$ Doc. T. .Mold. (2017), p. 415-416, nr. 280 (cu data de zi: „13”).

${ }^{595}$ În text, numele apare și sub forma: „Ignat”.

${ }^{596}$ Boga (1932a), p. 155, nr. XVII.

${ }^{597}$ Boga (1932a), p. 153, nr. XIV.

${ }^{598}$ Boga (1930c), p. 141, nr. VII; MEF, IV, p. 278-279, nr. 125.

${ }^{599}$ Boga (1932a), p. 152, nr. XIII.

${ }^{600}$ Paleograful a făcut această observație, pornind probabil de la ductul scrisului.

${ }^{601}$ Boga (1929d), p. 31, nr. XXVIII; MEF, IV, p. 145-146, nr. 57.

${ }^{602} \mathrm{MEF}, \mathrm{IV}$, p. $127-128$, nr. 49.

${ }^{603}$ Boga (1930c), p. 164-165, nr. XXVII (cu data de zi: 8). Unul din aceste două acte are data de zi greșită sau domnul a dat două hotărîri în aceeași pricină.

${ }^{604}$ Boga (1930c), p. 164, nr. XXVI; MEF, V, p. 247-248, nr. 104.

${ }^{605}$ Boga (1932a), p. 150-151, nr. XI. 


\begin{tabular}{|c|c|c|c|c|c|}
\hline 1989 & 1645 & mai & 16 & $\begin{array}{l}\text { Zapisul lui }<\text { Ursachi }{ }^{606} \text { Cornescul pentru o parte } \\
\text { din Forosna }\end{array}$ & " \\
\hline 1990 & 1834 & - & - & Planul satului Forosna & rusesc \\
\hline 1991 & 1813 & iulie & 23 & $\begin{array}{l}\text { Hotărîrea Departamentului I-iu în pricina lui } \\
\text { Ermolinschi }\end{array}$ & românesc și rusesc \\
\hline \multirow[t]{2}{*}{1992} & 1808 & iunie & 21 & Spița neamului Turbuleștilor & românesc \\
\hline & & & & Toate legate într-un dosar numit ${ }^{608}$ & copii \\
\hline 1993 & 1808 & iunie & 22 & $\begin{array}{l}\text { Mărturia răzeșilor din Cobâlca pentru judecata ce o } \\
\text { au }\end{array}$ & românesc \\
\hline 1994 & 1777 & iunie & 18 & Hotarnica moșiei Peresecina ${ }^{609}$ & ” \\
\hline 1995 & - & - & - & Hotarnica moşiei Teleșenca ${ }^{610}$ & " \\
\hline 1996 & 1777 & iunie & 21 & Mărturia hotarnică pentru moșia Peresecina ${ }^{611}$ & ” \\
\hline 1997 & 1775 & octombrie & 25 & $\begin{array}{l}\text { Cartea lui Grigore Ghica voievod pentru hotarele } \\
\text { moșiei Peresecina }^{612}\end{array}$ & " \\
\hline 1998 & 1775 & noiembrie & 2 & $\begin{array}{l}\text { Cartea lui Grigore Ghica voievod pentru hotarnica } \\
\text { moșiei Teleșenca }\end{array}$ & ” \\
\hline 1999 & 1777 & iunie & 20 & $\begin{array}{l}\text { Zapisul lui Cociorvă pentru o parte din moșia } \\
\text { Cobâlca }\end{array}$ & " \\
\hline 2000 & 1777 & septembrie & 2 & $\begin{array}{l}\text { Suretul zapisului lui Toader Popa pentru o parte din } \\
\text { Borzăști }\end{array}$ & " \\
\hline 2001 & 1777 & noiembrie & 27 & $\begin{array}{l}\text { Zapisul lui Toniță Darii pentru o parte din } \\
<\text { Sămănanca }>^{614}\end{array}$ & ” \\
\hline 2002 & 1777 & noiembrie & 7 & Zapisul lui Cernat pentru o parte Sămivanca & ” \\
\hline 2003 & 1749 & noiembrie & 10 & $\begin{array}{l}\text { Zapisul lui Sava Ciulacul pentru o parte din } \\
\text { Sămivanca }\end{array}$ & ” \\
\hline 2004 & 1766 & octombrie & - & Zapisul lui Ignat pentru o parte din Peresecina & ” \\
\hline 2005 & 1777 & decembrie & 24 & $\begin{array}{l}\text { Cartea lui Grigore Ghica voievod pentru hotarnica } \\
\text { moșiei Peresecina }\end{array}$ & " \\
\hline 2006 & 1810 & iunie & 16 & $\begin{array}{l}\text { Cartea Divanului pentru satele din raiaoa } \\
\text { Hotinului }\end{array}$ & " \\
\hline 2007 & 1779 & - & - & Perilipsis scrisorilor mănăstirii Trei Sfetitele & ” \\
\hline 2008 & 1814 & februarie & 14 & $\begin{array}{l}\text { Copia hotărîrii Judecătoriei Dorohoiu pentru niște } \\
\text { documente }\end{array}$ & " \\
\hline 2009 & 1665 & noiembrie & 1 & Suret de pe un zapis al lui Ștefan Petriceicu sluger ${ }^{615}$ & " \\
\hline 2010 & 1706 & iunie & 25 & Zapisul lui Ursul Costin pentru o parte de loc & " \\
\hline 2011 & 1882 & august & 6 & Mărturia dată lui Mihalache Dohatcu & ” \\
\hline 2012 & 1809 & decembrie & 7 & Jalba lui Dănilă „Haiduiul” către domn & ” \\
\hline 2013 & 1809 & decembrie & 24 & Zapisul lui Ioan pentru o parte din „Plăcintești” & " \\
\hline 2014 & 1823 & mai & 2 & $\begin{array}{l}\text { Copie după contractul de arendare a moșiei } \\
\text { Teleșeni }\end{array}$ & " \\
\hline 2015 & 1829 & ianuarie & 30 & Socoteala banilor datorați de Săndulachi „Balahma” & \# \\
\hline 2016 & 1823 & decembrie & 10 & Scrisoare către Stanco pentru niște zapise & ” \\
\hline 2017 & 1819 & aprilie & 20 & Scrisoarea lui Gheorghiadi pentru niște bani & " \\
\hline 2018 & 1822 & septembrie & 6 & Scrisoarea lui Curtiev pentru datorii & ” \\
\hline 2019 & 1818 & ianuarie & 18 & Contract de arendare a Teleneștilor & ” \\
\hline 2020 & 1817 & noiembrie & 20 & Contract de arendare a moșiei Mihalașa & ” \\
\hline
\end{tabular}

\footnotetext{
${ }^{606}$ În text, greșit: „Vasile”.

${ }^{607}$ Boga (1932a), p. 151-152, nr. XII.

${ }^{608} \mathrm{Nu}$ este clar la ce se referă această propoziție.

${ }^{609} \mathrm{Boga}$ (1938b), p. 106-120.

${ }^{610}$ Boga (1938b), p. 106-120 „Teleșeu”).

${ }^{611}$ Boga (1938b), p. 106-120 (cu data de zi: „22”).

${ }^{612}$ Boga (1937b), p. 145-148, nr. I.

${ }^{613}$ Boga (1937b), p. 150-153, nr. IV.

${ }^{614}$ În text: „Săminavca”.

${ }^{615}$ Boga (1932b), p. 319-320, nr. V (zapis pentru o parte din satul Fătcăuți).
} 


\begin{tabular}{|c|c|c|c|c|c|}
\hline 2021 & 1816 & ianuarie & 31 & Zapisul lui Gheorghe pentru o parte de „Bărăni” & " \\
\hline 2022 & 1819 & iulie & 28 & $\begin{array}{l}\text { Zapisul preotului Ghețiu pentru o parte de } \\
\text { „Bărăni” }\end{array}$ & " \\
\hline 2023 & 1777 & iulie & 31 & $\begin{array}{l}\text { Cartea lui Grigore Ghica pentru o danie a } \\
\text { mănăstirii Trei Sfetitele }\end{array}$ & " \\
\hline 2024 & 1794 & iulie & 15 & $\begin{array}{l}\text { Cartea lui Constantin Suțul voievod pentru o parte } \\
\text { din Sărățeni }\end{array}$ & ” \\
\hline 2025 & 1821 & noiembrie & 2 & $\begin{array}{l}\text { Zapisul lui Simion Costin pentru o parte din } \\
\text { Horghinești }\end{array}$ & " \\
\hline 2026 & 1822 & februarie & 22 & $\begin{array}{l}\text { Mărturia dată lui Ciornei pentru hotarele } \\
\text { Chipercenilor }\end{array}$ & ” \\
\hline 2027 & 1827 & aprilie & 27 & Mărturia lui N. C. Costin pentru satul Horghinești & ” \\
\hline 2028 & 1817 & august & 5 & Hotarnica moșiei Horghinești & ” \\
\hline 2029 & 1827 & ianuarie & 9 & Mărturia lui Ungureanu în chestia unor bani & ” \\
\hline 2030 & 1814 & noiembrie & 28 & Porunca Sărdăriei către ocolașul Culei & ” \\
\hline 2031 & 1815 & iunie & 6 & $\begin{array}{l}\text { Zapisul lui „Nani” Cărăbuș pentru o parte din } \\
\text { Puțintei }\end{array}$ & " \\
\hline 2032 & 1826 & aprilie & 7 & $\begin{array}{l}\text { Mărturia dată lui Manolachi Adam pentru un } \\
\text { schimb }\end{array}$ & ” \\
\hline 2033 & 1809 & martie & 8 & Zapisul lui Stratan pentru o parte din Nișcani & ” \\
\hline 2034 & 1804 & februarie & 20 & Cartea Divanului în pricina lui Nastase „Varbu” & " \\
\hline 2035 & 1808 & iunie & 13 & Jalba lui Ioniță Hâncul către Divan & ” \\
\hline 2036 & 1812 & martie & 2 & Jalba lui Ioniță Hâncul către Divan. & ” \\
\hline 2037 & 1809 & martie & 13 & Idem & ” \\
\hline 2038 & 1794 & ianuarie & 1 & Jalba lui Mihai Hâncul către domn & ” \\
\hline 2039 & 1751 & septembrie & 29 & $\begin{array}{l}\text { Cartea lui <Constantin> Mihai Racoviță voievod } \\
\text { pentru moșia Ciulucani }\end{array}$ & " \\
\hline 2040 & 1820 & februarie & 13 & Mărturia răzeșilor pentru hotarele moșiei Rădeni & " \\
\hline 2041 & 1820 & ianuarie & 21 & Mărturia pentru pricina lui Jărdan & ” \\
\hline 2042 & 1701 & septembrie & 9 & $\begin{array}{l}\text { Zapisul Ilenei, <fiica Săvucicăi> }{ }^{617} \text {, pentru o parte } \\
\text { din Puțintei }{ }^{618}\end{array}$ & " \\
\hline 2043 & 1740 & martie & 11 & $\begin{array}{l}\text { Dania preotului Vasile Gașpar, protopop de } \\
\text { Orheiu }^{619}\end{array}$ & " \\
\hline 2044 & $\begin{array}{l}<1734> \\
620\end{array}$ & decembrie & 20 & Zapisul de zestre al lui Patrașcu Loghin ${ }^{621}$ & " \\
\hline 2045 & 1814 & mai & 5 & Porunca Sărdăriei către căpitanul de mazili & ” \\
\hline 2046 & 1819 & martie & 17 & Socoteala datoriilor lui Cazimir & ” \\
\hline 2047 & 1811 & noiembrie & 29 & Zapisul dat lui Calmuțchi pentru moșia Moleștii & 川 \\
\hline 2048 & 1835 & august & 13 & $\begin{array}{l}\text { Cartea lui Constantin Nicolae <Mavrocordat }> \\
\text { voievod pentru o parte din Criuleni }\end{array}$ & $"$ \\
\hline 2049 & 1842 & iulie & 19 & $\begin{array}{l}\text { Scrisoarea lui A. Donici către }<\text { Dimitrachi } \\
\text { Ciolacoglu paharnic }{ }^{622}\end{array}$ & ” \\
\hline 2050 & 1820 & august & 23 & Scrisoarea lui $<$ Ciolacoglu $>{ }^{623}$ pentru niște bani & " \\
\hline 2051 & 1818 & iunie & 21 & Scrisoarea lui Vasili Cațichi pentru niște bani & ” \\
\hline 2052 & 1823 & august & 19 & $\begin{array}{l}\text { Scrisoarea lui <Zamfirachi> Rali pentru niște } \\
\text { bani }^{624}\end{array}$ & " \\
\hline
\end{tabular}

\footnotetext{
${ }^{616}$ Doc. T.. Mold., X, p. 53, nr. 33 (cu data de an: „1776”).

${ }^{617}$ În text: „Suruceancăi”.

${ }^{618}$ MEF, VI, p. 201-203, nr. 75 (cu data de an corectă: „1700”).

${ }^{619}$ În text, data de an greșită: „1748”. Boga (1929a), p. 11, nr. VII (cu data: 11 martie 1740 martie); MEF, VIII, p. 151, nr. 115.

${ }^{620}$ În text, data greșită: „1745”.

${ }^{621}$ Boga (1928a), p. 7, nr. I (cu data: „20 decembrie $1734<7243>$ ).

${ }^{622}$ În text: „Solocoglu”. Boga (1928b), p. 140, nr. CXCII. Pentru acest boier, vezi Duminică (2015), p. $124-126$.

${ }^{623}$ În text: „Chilimoglu”.

${ }^{624} \mathrm{Boga}(1928$ b), p. 95-96, nr. CXXIV.
} 


\begin{tabular}{|c|c|c|c|c|c|}
\hline 2053 & 1818 & noiembrie & 2 & Mărturia lui Gh. Druhuș pentru un zapis & $"$ \\
\hline 2054 & 1824 & martie & 25 & Zapisul lui Dudonu pentru o parte din Horghinești & " \\
\hline 2055 & 1822 & mai & 29 & $\begin{array}{l}\text { Dania lui Tudosie Costin pentru o parte din } \\
\text { Horghinești }\end{array}$ & " \\
\hline 2056 & 1821 & octombrie & 24 & $\begin{array}{l}\text { Zapisul lui Dorohan pentru o parte din } \\
\text { Horghinești }\end{array}$ & $"$ \\
\hline 2057 & 1815 & mai & 21 & Zapisul lui Gore pentru o parte din Horghinești & ” \\
\hline 2058 & 1826 & Iiunie & 10 & Mărturia vornicului de poartă Neculai & $"$ \\
\hline 2059 & 1825 & mai & 25 & Zapisul lui Dodonu pentru o parte din Horghinești & ” \\
\hline 2060 & 1817 & octombrie & 15 & Hotarnica moșiei Horghinești & 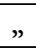 \\
\hline 2061 & 1820 & mai & 15 & $\begin{array}{l}\text { Zapisul lui Ilie Costin pentru o parte din } \\
\text { Horghinești }\end{array}$ & $"$ \\
\hline 2062 & 1785 & septembrie & 13 & Mărturie pentru hotarele satului Horghinești & ” \\
\hline 2063 & 1810 & august & 4 & Învoiala între răzeșii Scobicești și Cheptăvărești & ” \\
\hline 2064 & 1808 & septembrie & 7 & Porunca Sărdăriei către căpitanul de mazili & 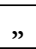 \\
\hline 2065 & 1732 & martie & 28 & $\begin{array}{l}\text { Cartea lui Grigorie Ghica voievod dată fraților } \\
\text { Panăș }{ }^{625}\end{array}$ & $"$ \\
\hline 2066 & 1798 & decembrie & 17 & $\begin{array}{l}\text { Cartea lui Alexandru Calimah voievod în pricina } \\
\text { Varzareștilor }\end{array}$ & ” \\
\hline 2067 & 1798 & iulie & 3 & Cartea de judecată pentru hotarele Volosănilor & $"$ \\
\hline 2068 & 1800 & iulie & 13 & Mărturie pentru hotarele satului Voloșeni & ” \\
\hline 2069 & 1810 & octombrie & 10 & $\begin{array}{l}\text { Cartea de judecată pentru niște cazuri de pe } \\
\text { „Băi”“626 }\end{array}$ & $"$ \\
\hline 2070 & - & - & - & Spița de neam a lui Toader Garuță & " \\
\hline 2071 & 1800 & ianuarie & 20 & Foaia de zestre a <Tudoscăi > 227 & 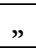 \\
\hline 2072 & 1828 & februarie & 25 & Contract de arendare a moșiei Păulești & 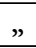 \\
\hline 2073 & 1782 & mai & 29 & $\begin{array}{l}\text { Mărturia lui Constantin Sturza pentru împărțeala } \\
\text { țiganilor }\end{array}$ & $"$ \\
\hline 2074 & 1762 & iulie & 21 & $\begin{array}{l}\text { Mărturia lui Constantin Sturza pentru împărțeala } \\
\text { țiganilor }\end{array}$ & $"$ \\
\hline 2075 & 1813 & decembrie & 15 & Schimbul făcut de Ivan Pruncul & 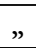 \\
\hline 2076 & $\begin{array}{l}\langle 1815> \\
628\end{array}$ & octombrie & 19 & Diata lui Alexandru Moruz voievod & $"$ \\
\hline 2077 & 1813 & decembrie & 15 & Mărturia lui Ioan Pruncul pentru schimbul făcut & " \\
\hline 2078 & 1815 & mai & 12 & Părțile din Cobâlca ale sărdăresei Maria Onofrei & ” \\
\hline 2079 & 1819 & septembrie & 9 & Actul de vînzare al moșiilor Doljoc și Dolineni & " \\
\hline 2080 & 1818 & iunie & 1 & Scrisoarea lui Filodor către Constantin ${ }^{629}$ & ” \\
\hline 2081 & 1820 & august & 2 & $\begin{array}{l}\text { Porunca Isprăvniciei către <căpitanul }>{ }^{630} \mathrm{de} \\
\text { Lipcani }\end{array}$ & $"$ \\
\hline 2082 & 1852 & aprilie & 17 & În pricina Ecaterinei Sturza ${ }^{631}$ & $"$ \\
\hline 2083 & 1849 & martie & 27 & Jurnalul în pricina Ecaterinei Sturza & ” \\
\hline 2084 & 1820 & aprilie & 24 & Contractul de arendare a tîrgușorului Telenești & $"$ \\
\hline 2085 & 1617 & august & 7 & $\begin{array}{l}\text { Copie după hotarnica moșiei Mașcăuți, < din } \\
\text { ținutul Orhei> } 632\end{array}$ & ” \\
\hline 2086 & 1816 & august & 22 & $\begin{array}{l}\text { Porunca ocîrmuirii oblastiei Basarabia în pricina lui } \\
\text { Iamandi }\end{array}$ & $"$ \\
\hline 2087 & 1818 & iunie & - & $\begin{array}{l}\text { Cartea lui Scarlat Ghica voievod pentru zestrea lui } \\
\text { Hermeziu }\end{array}$ & $"$ \\
\hline
\end{tabular}

${ }^{625} \mathrm{Boga}$ (1930b), p. 477-478, nr. I; MEF, VIII, p. 108-109, nr. 77.

${ }^{626}$ Așa în text.

${ }^{627}$ În text: „Tudoraicei”. Boga (1928a), p. 14-15, nr. VIII; Doc. T,. Mold., XI, p. 326-327, nr. 263.

${ }^{628}$ În text, data greșită: „1855”.

${ }^{629}$ Boga (1928b), p. 48-49, nr. LX.

${ }^{630}$ In text: „cazut”.

${ }^{631}$ Rezumatul nu are început.

${ }^{632}$ Boga (1938a), p. 13-16, nr. III (cu data de zi: „7”); MEF, I, p. 324-330, nr. 144 (cu data de zi: „2”). 


\begin{tabular}{|c|c|c|c|c|c|}
\hline 2088 & 1816 & iunie & 20 & $\begin{array}{l}\text { Copie după hotărîrea Divanului pentru zestrea lui } \\
\text { Hermeziu }\end{array}$ & $”$ \\
\hline 2089 & 1853 & - & - & Mărturia în pricina zestrei lui Hermeziu & ” \\
\hline 2090 & 1816 & ianuarie & 3 & Recepisa pentru primirea a cinci cai & ” \\
\hline 2091 & 1820 & decembrie & 14 & Cererea lui Hermeziu către Înaltul Sfat & 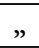 \\
\hline 2092 & 1810 & octombrie & 13 & Porunca Pîrcălăbiei către căpitanul Ilie Adam & " \\
\hline 2093 & 1846 & iunie & 2 & „Vechilimeaua”“33 dată de „Sundereci” & $"$ \\
\hline 2094 & 1773 & octombrie & 4 & Porunca Divanului către Sărdăria de Orhei & " \\
\hline 2095 & 1652 & septembrie & 18 & Cartea lui Vasilie voievod pentru satul Drăgușeni & ” \\
\hline 2096 & 1652 & mai & - & Zapisul lui Ștefan pentru o parte din Onișcani & ” \\
\hline 2097 & 1824 & decembrie & 5 & $\begin{array}{l}\text { Mărturia lui Bostan pentru Ioniță că e feciorul lui } \\
\text { Chepte }\end{array}$ & ” \\
\hline 2098 & 1809 & martie & 25 & Zapisul lui Stanciu pentru o grădină din Chișinău & $”$ \\
\hline 2099 & 1807 & august & 9 & Porunca Sărdăriei către Vasilie Mosor & " \\
\hline 2100 & 1823 & septembrie & 11 & $\begin{array}{l}\text { Porunca Isprăvniciei către ocolașul <de> Cogălnic, } \\
\text { Părlea }\end{array}$ & $"$ \\
\hline 2101 & 1824 & decembrie & 8 & Mărturia lui Postică pentru hotarele satului Biliești & ” \\
\hline 2102 & 1819 & februarie & 24 & $\begin{array}{l}\text { Scrisoarea arhimandritului Spiridoniei < din Iași > } \\
\text { către Anastasie }\end{array}$ & $"$ \\
\hline 2103 & 1805 & iunie & 27 & Jalba lui Ion Hâncul pentru moşia Pereni & ” \\
\hline 2104 & 1813 & septembrie & 21 & Referatul Sărdăriei pentru moșia Ruseștii & ” \\
\hline 2105 & 1812 & februarie & 19 & $\begin{array}{l}\text { Mărturia răzeșilor Rusești pentru moșia } \\
\text { Drăgușenilor }\end{array}$ & ” \\
\hline 2106 & 1813 & iulie & 28 & Chitanța lui Iordache Milo pentru 25 galbeni & ” \\
\hline 2107 & 1817 & august & 11 & Scrisoarea lui Rali către Vasilie pentru niște bani & " \\
\hline 2108 & 1814 & iunie & 15 & $\begin{array}{l}\text { Hotărîrea Departamentului I-iu pentru moșia } \\
\text { Cazanești }\end{array}$ & $"$ \\
\hline 2109 & 1828 & martie & 11 & $\begin{array}{l}\text { Zapisul <pîrcălabului }{ }^{634} \text { pentru o parte din moșia } \\
\text { „Mocileni” }\end{array}$ & ” \\
\hline 2110 & - & - & - & Spița neamului „Haltal” & ” \\
\hline 2111 & 1824 & ianuarie & 3 & $\begin{array}{l}\text { Vechilimeaua dată de Stefan Băț <lui> Sofroni } \\
\text { Cojocaru. }\end{array}$ & " \\
\hline 2112 & 1813 & august & 6 & Chitanța de 650 lei a lui Zamfir Rali & " \\
\hline 2113 & 1812 & septembrie & 2 & Mărturia lui Dumitrașcu pentru fata lui Apostol & " \\
\hline 2114 & 1810 & octombrie & 17 & $\begin{array}{l}\text { Porunca Sărdăriei către căpitanul de mazili al } \\
\text { ocolului Hotin }\end{array}$ & " \\
\hline 2115 & 1822 & aprilie & 28 & Mărturia lui Ioan Văluță pentru ceea ce dă fiilor săi & ” \\
\hline 2116 & 1869 & ianuarie & 15 & $\begin{array}{l}\text { Mărturia lui Costache Sturza pentru soția lui } \\
\text { Max<im> } 635\end{array}$ & " \\
\hline 2117 & - & - & - & Spița neamului Rusești & " \\
\hline 2118 & 1814 & mai & 29 & $\begin{array}{l}\text { Porunca Sărdăriei către căpitanul de mazili de la } \\
\text { ocolul Botnei }\end{array}$ & ” \\
\hline 2119 & 1813 & noiembrie & 20 & Mărturia lui Ioan dascalul pentru fata lui Toader & " \\
\hline 2120 & 1813 & iunie & 11 & $\begin{array}{l}\text { Porunca Sărdăriei către căpitanul din ocolul Botnei } \\
\text { (3 exemple) }\end{array}$ & ” \\
\hline 2121 & - & - & - & Spița neamului Cărlan & ” \\
\hline 2123 & - & - & - & Spița neamului < din moșia > Rusești & " \\
\hline 2124 & - & - & - & Spița răzeșilor de pe moșia Ulmeni & ” \\
\hline 2125 & - & - & - & Împărțeala între neamurile „Gumești” & " \\
\hline 2126 & 1822 & septembrie & 25 & Scrisoarea lui Zamfir Stamo către Curt & 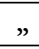 \\
\hline 2127 & 1810 & ianuarie & 2 & Zapisul lui Toader Pasat pentru moșia Bravicea & " \\
\hline
\end{tabular}

\footnotetext{
${ }^{63}$ În text: „,vochilirul”.

${ }^{634}$ În text: „lui părcapală”.

${ }^{635}$ Întregire posibilă.

${ }^{636}$ Numărul 2122 lipsește.
} 


\begin{tabular}{|c|c|c|c|c|c|}
\hline 2128 & 1810 & august & 10 & Porunca Sărdăriei Orheiu către Monolache Donici & " \\
\hline 2129 & 1729 & mai & 18 & Zapisul lui Ion Lungu pentru o parte din Vărzărești & ” \\
\hline 2130 & 1827 & noiembrie & 28 & $\begin{array}{l}\text { Hotărîrea comisiei de hotarnici pentru moșia } \\
\text { „Bocaniei” }\end{array}$ & " \\
\hline 2131 & 1824 & noiembrie & 24 & $\begin{array}{l}\text { Hotărîrea comisiei de hotarnici pentru moșia } \\
<\text { Dulejeni }>37\end{array}$ & $"$ \\
\hline 2132 & 1820 & februarie & 17 & $\begin{array}{l}\text { Învoiala între răzeșii Plămadă pentru moșia } \\
\text { Drăgușeni }\end{array}$ & $"$ \\
\hline 2133 & 1791 & decembrie & 21 & $\begin{array}{l}\text { Hotarnica moșiei Petricani, < din ținutul } \\
\text { Lăpușna }>638\end{array}$ & $"$ \\
\hline 2134 & 1804 & august & 5 & Spița neamului Rusul, începînd de la anul 1607 & ” \\
\hline 2135 & - & - & - & Spița neamului Mager & 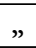 \\
\hline 2136 & 1787 & iunie & 17 & $\begin{array}{l}\text { Zapisul lui Grigorie <Clichie }>{ }^{639} \text { "Clieilici” p. o } \\
\text { parte din Milești }\end{array}$ & $"$ \\
\hline 2137 & 1816 & decembrie & 14 & $\begin{array}{l}\text { Hotărîrea Departamentului I-iu în pricina } \\
\text { Iordaniei Gomonova }\end{array}$ & " \\
\hline 2138 & 1804 & august & 5 & Spița neamului Rusul & ” \\
\hline 2139 & 1809 & aprilie & 12 & Diata lui Sava „Deban” & " \\
\hline 2140 & - & - & - & Spița neamului Rusul & ” \\
\hline 2141 & 1813 & august & 6 & Hotarnica moșiei „Boranci”641 & ” \\
\hline 2142 & 1812 & octombrie & 1 & $\begin{array}{l}\text { Porunca Sărdăriei către căpitanul de mazili al } \\
\text { ocolului <Botna } 642\end{array}$ & $"$ \\
\hline 2143 & 1800 & martie & 12 & $\begin{array}{l}\text { Raportul preotului din Orheiu pentru văduva } \\
\text { Smaranda }\end{array}$ & ” \\
\hline 2144 & 1824 & august & 18 & Jurnalul Verhovnului Sovet ${ }^{643}$ pentru moșia Milești & $"$ \\
\hline 2145 & 1801 & noiembrie & 5 & Învoiala răzeșilor de pe moșia Milești & ” \\
\hline 2146 & 1812 & februarie & 1 & Învoiala între moștenitorii familiei Vicol & " \\
\hline 2147 & 1778 & august & 12 & $\begin{array}{l}\text { Cartea lui Constantin Moruzi voievod dată lui } \\
\text { Vasilie Razul }\end{array}$ & $"$ \\
\hline 2148 & 1809 & iunie & 26 & Mărturia lui Dumbravă pentru moșia Unguraș ${ }^{644}$ & 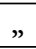 \\
\hline 2149 & 1809 & iulie & 7 & $\begin{array}{l}\text { Scrisoarea lui Iordache pentru hotarele moșiei } \\
\text { Unguraș }\end{array}$ & $"$ \\
\hline 2150 & 1819 & ianuarie & 20 & $\begin{array}{l}\text { Scrisoarea arhimandritului Spiridoniei < din Iași > } \\
\text { pentru niște cai }\end{array}$ & ” \\
\hline 2151 & 1815 & iunie & 26 & Publicația pentru vînzarea unei părți < din > Sferja & $"$ \\
\hline 2152 & 1814 & mai & 12 & Porunca Sărdăriei de Orheiu către Mărzacu & " \\
\hline 2153 & 1817 & octombrie & 26 & Contract de arendare a moșiei Nișcanii & " \\
\hline 2154 & 1786 & august & 7 & Țidulă pentru 24 stînjeni din moșia Pojoreni & 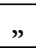 \\
\hline 2155 & 1822 & decembrie & 19 & Zapisul lui Criste pentru o parte din Isacova & " \\
\hline 2156 & 1818 & martie & 13 & Zapisul Elenei pentru o parte din Peresecina & 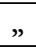 \\
\hline 2157 & 1808 & iulie & 2 & $\begin{array}{l}\text { Copia zapisului lui Trofim pentru o parte din } \\
\text { Cornova }\end{array}$ & ” \\
\hline 2158 & 1814 & iunie & 25 & $\begin{array}{l}\text { Porunca Departamentului I-iu în pricina lui } \\
\text { Săcheraș }\end{array}$ & ” \\
\hline 2159 & 1826 & mai & 24 & Spița neamului Trohin & 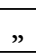 \\
\hline 2160 & 1777 & iunie & 22 & Împărțeala moșiei Peresecina & ” \\
\hline 2161 & 1818 & februarie & 15 & Chitanța lui Dimitrie Platon pentru 4.241 <lei> & 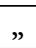 \\
\hline
\end{tabular}

${ }^{637}$ În text: „Dolajeni”. Candu (2016), p. 58-88 (studiu realizat pe temeiul unei mărturii hotarnice, din 10 noiembrie 1803 , păstrată la BAR, Doc. ist., CXIV/172).

${ }^{638}$ Boga (1938a), p. 143-150, nr. XLVI.

${ }^{639}$ În text: „Clieilici”.

${ }^{640}$ Doc. T. Mold., X, p. 219-220, nr. 172 (cu data corectă: „16 iunie 1786”).

${ }^{641}$ Poate „Borăni”.

${ }^{642}$ În text: „Buhnea”.

${ }^{643}$ Consiliul (Sfatul) Suprem al Basarabiei (Бессарабский Верховныцй Совет).

${ }^{644}$ „Unguri” (ținutul Soroca). 


\begin{tabular}{|c|c|c|c|c|c|}
\hline 2162 & 1719 & ianuarie & 10 & Mărturia lui Hariton pentru niște datorii & ” \\
\hline 2163 & 1807 & decembrie & 13 & Jalba lui Constantin Jerdan pentru moșia Unguraș & ” \\
\hline 2164 & 1817 & - & - & Socoteala lui Gheorghe Dumitriu & grecesc \\
\hline 2165 & 1813 & aprilie & 5 & Scrisoarea lui Stamo în chestia unor bani & $"$ \\
\hline 2166 & 1807 & martie & - & Învoiala între răzeșii < din > Bravicea & ” \\
\hline 2167 & 1810 & mai & 9 & Mărturia lui Gherguță pentru o vie & ” \\
\hline 2168 & 1820 & octombrie & 4 & Zapisul vatavului Ruscinschi pentru satul Purcari & ” \\
\hline 2169 & - & martie & 8 & Zapisul lui Lazar pentru o grădină & 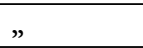 \\
\hline 2170 & 1821 & ianuarie & 8 & $\begin{array}{l}\text { Zapisul lui Grigoraș Jardan pentru o parte din } \\
\text { Ghetelova, <din ținutul Orhei> }\end{array}$ & $"$ \\
\hline 2171 & 1812 & ianuarie & 10 & Zapisul lui Iordache Păun pentru 300 galbeni & ” \\
\hline 2172 & 1812 & decembrie & 12 & Zapisul lui Toader Crețescu pentru 500 1ei & ” \\
\hline 2173 & - & - & - & Răvașul lui Toader Crețescu pentru niște bani & 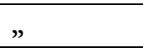 \\
\hline 2174 & 1813 & mai & 27 & Zapisul lui Ionache Păun pentru 19 stînjeni piatră & ” \\
\hline 2175 & 1815 & septembrie & 30 & $\begin{array}{l}\text { Porunca Departamentului I-iu către Sărdăria de } \\
\text { Orheiu }\end{array}$ & $"$ \\
\hline 2176 & 1816 & februarie & 12 & Zapisul lui Moldovanu pentru niște cărămizi & ” \\
\hline 2177 & 1814 & aprilie & 15 & Porunca Sărdăriei pentru clironomia lui I. Văluță & ” \\
\hline 2178 & 1811 & iunie & 18 & Zapisul lui Văluță pentru o parte din Onișcani & ” \\
\hline 2179 & 1814 & mai & 23 & $\begin{array}{l}\text { Referatul <căpitanului > }{ }^{645} \text { de ocolul Cula către } \\
\text { Sărdăria Orheiu }\end{array}$ & ” \\
\hline 2180 & 1820 & iunie & 30 & Diata lui Ioniță, < fiul lui Toader > Vuluță ${ }^{646}$ & ” \\
\hline 2181 & 1844 & octombrie & 16 & Spița neamului Drăgan din moșia Cojuşna & ” \\
\hline 2182 & 1833 & aprilie & 26 & Împărțeala moșiilor Brăviceștilor & rusesc \\
\hline 2183 & 1795 & mai & 11 & Zapisul lui Fotescu pentru spița familiei lui & românesc \\
\hline 2184 & 1801 & iulie & 18 & $\begin{array}{l}\text { Zapisul lui Andronache Hârtie pentru „Vasul } \\
\text { Tărei” } 647\end{array}$ & $"$ \\
\hline 2185 & 1803 & septembrie & 20 & Cartea Divanului în pricina lui Vasilie Fotescu & ” \\
\hline 2186 & 1809 & mai & 17 & $\begin{array}{l}\text { Zapisul lui Andronache Hartie pentru moșia } \\
\text { Mătăsenii }\end{array}$ & ” \\
\hline 2187 & 1819 & aprilie & 9 & Zapisul lui Caracaș pentru o parte din Bogheni & " \\
\hline 2188 & 1819 & ianuarie & 14 & Scrisoarea lui Vasilie Fotescul către Dumitrache ${ }^{648}$ & $"$ \\
\hline 2189 & 1820 & mai & 24 & $\begin{array}{l}\text { Zapisul lui Mândrilă pentru o parte din } \\
\text { Dumbrăviță }\end{array}$ & $"$ \\
\hline 2190 & - & - & - & Povesca Isprăvniciei către Dimitrie Fotescu & ” \\
\hline 2191 & 1801 & august & 22 & Împărțeala moșiei Mătăseni & ” \\
\hline 2192 & 1823 & ianuarie & 13 & Zapisul lui Toma Ghine pentru o parte din Bogheni & ” \\
\hline 2193 & 1823 & ianuarie & 13 & $\begin{array}{l}\text { Zapisul lui Condurache pentru o parte din } \\
\text { Mătăseni }\end{array}$ & $"$ \\
\hline 2194 & 1830 & decembrie & 14 & $\begin{array}{l}\text { Mărturia răzeșilor pentru moșia Rusești, < din } \\
\text { ținutul Orhei> }\end{array}$ & $"$ \\
\hline 2195 & 1827 & mai & 31 & Povesca Judecătoriei Orhei către Toderașcu Cărlan & ” \\
\hline 2196 & 1823 & iunie & 10 & $\begin{array}{l}\text { Mărturia lui Gheorghe Sava pentru o parte din } \\
\text { Gărlele, <din ținutul Orhei> }\end{array}$ & $"$ \\
\hline 2197 & 1820 & martie & 10 & Scrisoarea lui Rali în chestia unor bani & ” \\
\hline 2198 & 1820 & februarie & 26 & Scrisoarea lui Rali în chestia unor bani & grecesc \\
\hline 2199 & 1820 & februarie & 3 & $\begin{array}{l}\text { Scrisoarea lui Zamfirescu Rali către Dimitrie Curti } \\
\text { in chestia tovărășiei încheiate }\end{array}$ & $"$ \\
\hline 2200 & 1663 & septembrie & 13 & Hotarnica moșiei Sărbiceni $^{649}$ & $"$ \\
\hline
\end{tabular}

\footnotetext{
${ }^{645}$ În text: „căzut”.

${ }^{646}$ Boga (1929a), p. 63-64, nr. XXXIX.

${ }^{647}$ Foarte greu de presupus ce se ascunde sub aceste cuvinte (vezi și mai sus).

${ }^{648} \mathrm{Boga}(1928$ b), p. 51, nr. LXIII.

${ }^{649} \mathrm{MEF}, \mathrm{V}$, p. $83-88$, nr. 28 (cu data de an: „1662”).
} 


\begin{tabular}{|c|c|c|c|c|c|}
\hline 2201 & 1632 & august & 5 & $\begin{array}{l}\text { Suret după cartea lui Iliaș voievod, dată lui Simion } \\
\text { Pilipovschi, pentru satele: Mihalcăuți Văscăuți, } \\
\text { Zubricenii, Blescinăuții, <Marșinți }{ }^{650}\end{array}$ & românesc \\
\hline 2202 & 1611 & septembrie & 4 & $\begin{array}{l}\text { Suret după cartea lui Constantin Movilă voievod, } \\
\text { dată lui Nistor portariu, pentru satul Gvozdăuții } 651\end{array}$ & ” \\
\hline 2203 & 1611 & iulie & 19 & $\begin{array}{l}\text { Suret după cartea lui Constantin Movilă voievod, } \\
\text { dată lui Vrânceanu postelnic, pentru satul } \\
\text { Șărbiceni }\end{array}$ & $”$ \\
\hline 2204 & 1608 & mai & 12 & $\begin{array}{l}\text { Suret după cartea lui Constantin Movilă voievod, } \\
\text { dată lui Simion Pilipovschi, pentru satul } \\
\text { Șărbiceni } 653\end{array}$ & ” \\
\hline 2205 & 1811 & mai & 15 & $\begin{array}{l}\text { Cartea Divanului Moldovei în pricina moștenirei } \\
\text { familiei boierilor Buhușești }\end{array}$ & copie românească \\
\hline 2206 & 1812 & martie & 20 & $\begin{array}{l}\text { Cartea Divanului Moldovei în pricina Buhușeștilor } \\
\text { pentru moșia Bilavinții }\end{array}$ & ” \\
\hline 2207 & - & - & - & Împărțeala moșiilor familiei Buhuși & românesc \\
\hline 2208 & 1813 & decembrie & 30 & Schimbul moșiilor Buhușeștilor & 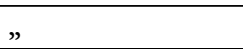 \\
\hline 2209 & - & - & - & Împărțeala moșiilor familiei Buhuș & ” \\
\hline 2210 & 1815 & octombrie & 16 & $\begin{array}{l}\text { Zapisul de vînzare al moșiei Gvozdăuții, a lui } \\
\text { Cheșcu }\end{array}$ & " \\
\hline 2211 & 1816 & martie & 30 & $\begin{array}{l}\text { Hotărîrea Departamentului I-iu în pricina lui Ion } \\
\text { Cheșcu }\end{array}$ & ” \\
\hline 2212 & 1817 & februarie & 8 & $\begin{array}{l}\text { Zapisul lui Ion Cheșcu pentru moșia Todirenii, } \\
\text { Mălăeștii }\end{array}$ & $”$ \\
\hline 2213 & 1817 & martie & 3 & Cererea lui Sandu Feodosiu pentru moșia Văzdăuții & ” \\
\hline 2214 & 1817 & martie & 14 & $\begin{array}{l}\text { Povestca Departamentului al 2-lea către Tudorache } \\
\text { Ciurea pentru moșia Văzdăuții }\end{array}$ & $"$ \\
\hline 2215 & 1817 & martie & 17 & $\begin{array}{l}\text { Răspunsul lui Tudorache Ciurea către } \\
\text { Departamentul al 2-lea pentru moșia Văzdăuții }\end{array}$ & ” \\
\hline 2216 & 1818 & martie & - & $\begin{array}{l}\text { Învoiala între Tudorache Ciurea și Sandu Feodosiu } \\
\text { pentru moșia Văzdăuții. }\end{array}$ & ” \\
\hline 2217 & 1840 & noiembrie & 14 & $\begin{array}{l}\text { Învoiala între Sandulache Tomuleț și Dimitrie } \\
<\text { Namesnicu }{ }^{654} \text { pentru o moștenire }\end{array}$ & rusesc \\
\hline 2218 & 1840 & & & Planul moșiei Văzdăuții și a moșiilor învecinate & ” \\
\hline 2219 & 1822 & iunie & 2 & $\begin{array}{l}\text { Hotărîrea Înaltului Sfat în pricina raăzeșilor din } \\
\text { moșia Șendreni și Milești }\end{array}$ & românesc \\
\hline 2220 & 1836 & septembrie & 23 & $\begin{array}{l}\text { Hotărîrea în pricina moşiilor „Hodoroncii” }{ }^{655} \text { și } \\
\text { Gvozdăuții }\end{array}$ & rusesc \\
\hline 2221 & 1814 & octombrie & 15 & $\begin{array}{l}\text { Raportul Divanului Moldovei în pricina lui Ioniță } \\
\text { Boian și Nicolae Gherghel }\end{array}$ & $”$ \\
\hline 2222 & 1809 & octombrie & 24 & $\begin{array}{l}\text { Hotărîrea Divanului Moldovei pentru moșiile lui } \\
\text { Ioniță Boian }\end{array}$ & românesc, copie \\
\hline 2223 & 1830 & septembrie & 19 & $\begin{array}{l}\text { Porunca Divanului Moldovei către Pîrcălăbia de } \\
\text { Hotin pentru moșiile lui Ioniță Boian }\end{array}$ & românesc \\
\hline 2224 & 1812 & martie & 18 & $\begin{array}{l}\text { Cartea Divanului Moldovei pentru moșiile lui I. } \\
\text { Boian }\end{array}$ & $”$ \\
\hline 2225 & 1813 & decembrie & 21 & $\begin{array}{l}\text { Zapisul lui Costache Flondor pentru moșia } \\
\text { Cobâlceni, din ținutul Hotinului }\end{array}$ & copie \\
\hline 2226 & 1814 & octombrie & 23 & $\begin{array}{l}\text { Porunca Departamentului I-iu către Părcălăbia } \\
\text { Hotinului în pricina Mariei Stroescu }\end{array}$ & românesc \\
\hline
\end{tabular}

${ }^{650} \mathrm{MEF}$, III, p. 290-293, nr. 143.

${ }^{651} \mathrm{MEF}, \mathrm{I}$, p. 275-278, nr. 122.

${ }^{652} \mathrm{MEF}, \mathrm{I}$ p. 272-274, nr. 120.

${ }^{653} \mathrm{MEF}, \mathrm{I}$, p. 225-226, nr. 98.

${ }^{654}$ În text: „Nasmeșcu”.

${ }^{655}$ Probabil, Horodiște (Horodești). 


\begin{tabular}{|c|c|c|c|c|c|}
\hline 2227 & 1815 & mai & 26 & $\begin{array}{l}\text { Referatul Pîrcălăbiei Hotinului pentru moșia Criva } \\
\text { și Gvozdăuți } \\
656\end{array}$ & ” \\
\hline 2228 & - & - & - & $\begin{array}{l}\text { Scrisoarea lui Ioan Cheșcul către Cazimir pentru } \\
\text { niște bani }\end{array}$ & ” \\
\hline 2229 & 1818 & februarie & 1 & $\begin{array}{l}\text { Scrisoarea lui Iordache Donici către Cazimir pentru } \\
\text { niște moșii, din ținutul Hotin }\end{array}$ & ” \\
\hline 2230 & 1879 & august & 7 & $\begin{array}{l}\text { Porunca Judecătoriei ținutului Hotin către } \\
\text { Dimitrie Beldiman pentru moșia Văzdăuți }\end{array}$ & ” \\
\hline 2231 & 1831 & iunie & 24 & Diata lui Ioan Stavilă & ” \\
\hline 2232 & 1859 & noiembrie & 10 & Atestaţie de spiţă a neamului Lambrino & " \\
\hline 2233 & 1817 & iunie & 24 & $\begin{array}{l}\text { Scrisoarea lui Zamfir Stamo către Gheorghiadi în } \\
\text { chestia unor datorii }\end{array}$ & $\begin{array}{l}\text { grecesc, cu trad. } \\
\text { românească }\end{array}$ \\
\hline 2234 & - & - & - & $\begin{array}{l}\text { Însemnare de lucrurile ce se vor cumpăra la } \\
\text { iarmarocul de la Lipsca }\end{array}$ & " \\
\hline 2235 & 1816 & iulie & 29 & $\begin{array}{l}\text { Scrisoarea lui Zamfir Stamo către Gh. Dimitriu în } \\
\text { chestia unor bani }\end{array}$ & ” \\
\hline 2236 & - & - & - & $\begin{array}{l}\text { Opis al documentelor moșiei Clișcăuți a mănăstirii } \\
\text { Goliei }\end{array}$ & românesc \\
\hline 2237 & 1831 & iulie & 14 & $\begin{array}{l}\text { Polița de } 200 \text { ruble argint, semnată de unii răzeși } \\
\text { din Hercești }{ }^{658} \text { și Mănzătești }\end{array}$ & rusesc \\
\hline 2238 & 1821 & decembrie & 11 & $\begin{array}{l}\text { Răvașul smotritelui }{ }^{659} \text { poștelor către poșta din } \\
\text { Gotești pentru darea unor cai }\end{array}$ & românesc \\
\hline 2239 & 1820 & iulie & 3 & Scrisoarea către Ioan Huluvei în chestia unei case & ” \\
\hline 2240 & 1837 & octombrie & 21 & Contract de arendare a moșiei Camencii & rusesc \\
\hline 2241 & 1821 & martie & 24 & $\begin{array}{l}\text { Zapisul Vărvarii, femeia lui Lazăr bărghieru, prin } \\
\text { care se angajează ca servitoare la Elenco „Gulac” }{ }^{2} 60 \\
\text { din Chișinău }\end{array}$ & $\begin{array}{l}\text { românesc (în dublu } \\
\text { exemplar) }\end{array}$ \\
\hline 2242 & 1821 & martie & 26 & $\begin{array}{l}\text { Zapisul lui Andrei Vanglovschi prin care se } \\
\text { angajează servitor la Elenca „Gulac” din Chișinău }\end{array}$ & românesc \\
\hline 2243 & - & - & - & $\begin{array}{l}\text { Opis arătător documentelor pentru moșiile: } \\
\text { Rohotinului, < Trebisăuți }{ }^{661} \text { și Malinții, din } \\
\text { județul Hotinului }\end{array}$ & ” \\
\hline 2244 & 1821 & - & - & $\begin{array}{l}\text { Polițe de diferite sume, semnate de Ștefan Casso din } \\
\text { Iași, plătibile la „Iarmarocul Sf. Mihail” din Lipsca } \\
\text { (șasesprezece bucăți) }\end{array}$ & rusesc \\
\hline 2245 & 1824 & ianuarie & 13 & Diata lui Dimitrie Gane ${ }^{662}$ & românesc \\
\hline 2246 & $\begin{array}{l}1817- \\
67\end{array}$ & & & $\begin{array}{l}\text { Diverse scrisori, în majoritate aparținînd familiei } \\
\text { „Gulac”, cu cuprins familiar. Unele din ele au și } \\
\text { cuprins de afaceri comerciale ( } 43 \text { bucăți) }\end{array}$ & rusești \\
\hline 2247 & 1817 & - & - & $\begin{array}{l}\text { Copii după contracte de arendare a diferitelor moșii } \\
\text { din Basarabia, în nouăzeci și opt (98) bucăți, toate } \\
\text { rusești }\end{array}$ & ” \\
\hline 2248 & & & & $\begin{array}{l}\text { Pecetea Judecătoriei Politicești a Basarabiei (în } \\
\text { românește) }\end{array}$ & românesc \\
\hline 2249 & & & & $\begin{array}{l}\text { Peceți ale diferitelor Judecătorii de ținuturi din } \\
\text { Basarabia (treisprezece bucăți) }\end{array}$ & rusești \\
\hline $\begin{array}{c}2249 \\
663\end{array}$ & 1856 & - & - & $\begin{array}{l}\text { Carnet, legat cu pomelnic, al morților și viilor } \\
\text { (probabil al familiei Hajdău) }\end{array}$ & românesc \\
\hline
\end{tabular}

${ }^{656}$ Gvozdăuți (Văzdăuți), sat, în ținutul Hotin.

${ }^{657}$ Boga (1929a), p. 69-70, nr. XLI.

658 „Hârcești”.

659 „comandantului”.

${ }^{660}$ Probabil: „Ciulac/Ciolac”.

${ }^{661}$ În text: „Prebicăuți” (vezi și mai sus).

${ }^{662}$ Boga (1929a), p. 58-59, nr. XXXV.

${ }^{663}$ Număr dublat. 


\begin{tabular}{|c|c|c|c|c|c|}
\hline 2250 & 1836 & aprilie & 1 & $\begin{array}{l}\text { Condica întru care se trec toate cheltuielile, ce se fac } \\
\text { de familia Hajdău }\end{array}$ & " \\
\hline 2251 & 1834 & mai & 4 & Condică de cheltuieli a familiei Hajdău & ” \\
\hline 2252 & 1826 & ianuarie & 8 & Contractul de arendare a moșiei Glodeni & ” \\
\hline 2253 & 1849 & septembrie & 14 & Condica de socoteală a familiei Hajdău & ” \\
\hline 2254 & 1839 & octombrie & 8 & Condica de venituri și cheltuieli a familiei Hajdău & ” \\
\hline 2255 & 1866 & mai & 20 & Condica de intrare și ieșire, partea a III-a & rusesc \\
\hline 2256 & & & & $\begin{array}{l}\text { Diverse copii de pe contracte de arendare a moșiilor } \\
<\text { din > Basarabia ( } 53 \text { bucăți) }\end{array}$ & rusești \\
\hline 2257 & 1828 & martie & 28 & $\begin{array}{l}\text { Zapisul lui Toader Mardari pentru vînzarea unei } \\
\text { părți din Flămânzeni }\end{array}$ & românești \\
\hline 2258 & 1848 & septembrie & 1 & Contract de arendare a moșiei „Lata”664 & " \\
\hline 2259 & 1817 & decembrie & 11 & Contract de arendare a moșiei Cozmeni & ” \\
\hline 2260 & 1835 & septembrie & 4 & $\begin{array}{l}\text { Adresa Logofeției Dreptății către serdarul Vasilie } \\
\text { Popovici în pricina moștenirii Samaracova }\end{array}$ & $\begin{array}{l}<\text { românesc>, cu trad. } \\
\text { rusească }\end{array}$ \\
\hline 2261 & 1821 & noiembrie & 25 & $\begin{array}{l}\text { Pricina hotarelor moșiei Ceabrău, din județul } \\
\text { Hotin }\end{array}$ & " \\
\hline 2262 & 1856 & august & 7 & $\begin{array}{l}\text { Copia jurnalului Tribunalului Hotin în pricina } \\
\text { moștenirii lui Chiruș }\end{array}$ & rusesc \\
\hline 2263 & 1811 & decembrie & 17 & $\begin{array}{l}\text { În pricina moșiilor paharnicului Tudorache Ciurea, } \\
\text { din ținutul Hotinului }\end{array}$ & $\begin{array}{l}\text { românesc, cu trad. } \\
\text { rusească }\end{array}$ \\
\hline 2264 & $\begin{array}{l}<1806> \\
665\end{array}$ & iulie & 29 & $\begin{array}{l}\text { În pricina moșiei logofătului Iordache } \\
\text { Cantacuzino, din județul Hotin }\end{array}$ & ” \\
\hline 2265 & 1671 & iunie & 17 & $\begin{array}{l}\text { Copie. Cartea lui Duca voievod prin care întărește } \\
\text { vînzarea făcută de Gavril Brăescul }\end{array}$ & ” \\
\hline 2266 & 1698 & iulie & 8 & $\begin{array}{l}\text { Copie. Mărturia lui Sava starostele de negustori din } \\
\text { Iași pentru moșia Ceabrăul }\end{array}$ & ” \\
\hline 2267 & 1710 & noiembrie & 20 & $\begin{array}{l}\text { Zapisul lui Leon Adam prin care vinde jumătate din } \\
\text { Ceabrău }\end{array}$ & ” \\
\hline 2268 & 1713 & februarie & 20 & $\begin{array}{l}\text { Copie. Cartea lui Nicolae Alexandru } \\
<\text { Mavrocordat }>\text { voievod, dată lui Antohie Jora, } \\
\text { pentru strîngerea de oameni la Ceabrău }\end{array}$ & ” \\
\hline 2269 & 1714 & martie & 29 & $\begin{array}{l}\text { Copie. Cartea lui Nicolae Alexandru } \\
<\text { Mavrocordat > voievod în pricina căpitanului } \\
<\text { Iosâp }>\text { cu Vasilache }<\text { călărașul }{ }^{667}\end{array}$ & ” \\
\hline 2270 & 1809 & octombrie & 24 & $\begin{array}{l}\text { Cartea Divanului, dată lui Constantin Bocan, } \\
\text { pentru partea din moșia Gvăzdăuți }\end{array}$ & ” \\
\hline 2271 & 1812 & martie & 18 & $\begin{array}{l}\text { Cartea Divanului, dată lui Tudorache Ciure, pentru } \\
\text { moșiile Mileștii și Grumăzenii, <din ținutul Hotin> }\end{array}$ & " \\
\hline 2272 & 1812 & martie & 29 & $\begin{array}{l}\text { Cartea Divanului pentru moșiile Buhușeștilor, din } \\
\text { județul Hotin }\end{array}$ & copie \\
\hline 2273 & 1812 & aprilie & 27 & $\begin{array}{l}\text { Adresa Divanului către președintele Divanului în } \\
\text { pricina moșiilor din Hotin }\end{array}$ & " \\
\hline 2274 & 1814 & decembrie & 12 & $\begin{array}{l}\text { În pricina de judecată a familiei Buhuş pentru } \\
\text { moșia din Hotin }\end{array}$ & " \\
\hline 2275 & 1821 & noiembrie & 12 & $\begin{array}{l}\text { Zapisul lui Vardalah pentru o parte din moșia } \\
\text { Drepcăuți, <din ținutul Hotin> }\end{array}$ & copie, cu trad. rusească \\
\hline 2276 & 1810 & decembrie & 2 & $\begin{array}{l}\text { Schimb de moșii între Ioniță Bocan și Teodor } \\
\text { Ciurea }\end{array}$ & românesc \\
\hline 2277 & 1801 & martie & 12 & $\begin{array}{l}\text { Cartea Divanului pentru moșia Treisteni, din } \\
\text { județul Hotin }\end{array}$ & $"$ \\
\hline
\end{tabular}

\footnotetext{
${ }^{664}$ Poate „Larga”.

${ }^{665}$ În text, greșit: „1856”.

${ }^{666}$ MEF, VI, p. 67-69, nr. 13.

667 În text: „cărăușul”. MEF, VIII, p. 27-28, nr. 9 (cu data: „29 martie 1715”).
} 


\begin{tabular}{|c|c|c|c|c|c|}
\hline 2278 & 1814 & iulie & 24 & $\begin{array}{l}\text { Mărturia lui Constantin Stroescul pentru niște } \\
\text { moșii din județul Hotin }\end{array}$ & $"$ \\
\hline 2279 & 1832 & octombrie & 25 & Mărturia cu privire la anul nașterii lui Ion Hajdău & ” \\
\hline 2280 & 1842 & iunie & 16 & Spița neamului Hajdău & rusesc \\
\hline 2281 & 1825 & martie & 20 & $\begin{array}{l}\text { Hotărîrea Judecătoriei Hotin în pricina lui Ioan } \\
\text { Moșanu cu Tudorache Ciurea }\end{array}$ & $\begin{array}{l}\text { românesc, cu trad. } \\
\text { rusească }\end{array}$ \\
\hline 2282 & 1826 & noiembrie & 27 & $\begin{array}{l}\text { Învoiala între Mihai Moșanu și Tudorache Ciure } \\
\text { pentru moșii }\end{array}$ & ” \\
\hline 2283 & 1822 & iulie & 29 & Scrisoarea lui Ion Cazimir către Toader Hajdău & copie românească \\
\hline 2284 & 1823 & februarie & 8 & Scrisoarea lui Ioan Cazimir către Toader Hajdău ${ }^{668}$ & românesc, orig. și copie \\
\hline 2285 & 1824 & iulie & 30 & $\begin{array}{l}\text { Povestca Verhavanului Sovet }{ }^{669} \text { către Toader } \\
\text { Hajdău }\end{array}$ & românesc \\
\hline 2286 & 1828 & februarie & 1 & Scrisoarea Catincăi Cazimir către Toader Hajdău ${ }^{670}$ & ” \\
\hline 2287 & 1824 & noiembrie & 1 & $\begin{array}{l}\text { Jalba lui I. Cazimir către Judecătoria ținutului } \\
\text { Hotin pentru Novoselița }\end{array}$ & " \\
\hline 2288 & 1830 & martie & 13 & Vechilime dată lui Leopold $<$ Junter $>^{671}$ & ” \\
\hline 2289 & 1830 & martie & 13 & Hotărîrea arbitrilor în chestia moșiei Albinețul & ” \\
\hline 2290 & 1827 & august & 8 & $\begin{array}{l}\text { Declarația lui Leopold <Junter > pentru moșia } \\
\text { Albineț }\end{array}$ & $"$ \\
\hline 2291 & 1827 & august & 3 & $\begin{array}{l}\text { Jalba sătenilor din Pânzăreni }{ }^{672} \text { în contra } \\
\text { arendașilor }\end{array}$ & ” \\
\hline 2292 & 1827 & august & 7 & Jalba lui Leopold Junter, posesorul moșiei Tuzora & ” \\
\hline 2293 & 1815 & octombrie & 21 & Învoiala între moștenitorii familiei Hâjdău & orig. și copie, românesc \\
\hline 2294 & 1817 & martie & 16 & Compromis între moștenitorii familiei Hajdău & românesc \\
\hline 2295 & 1817 & mai & 1 & Mărturia lui Teodor Ciurea pentru niște moșii & ” \\
\hline 2296 & 1816 & iunie & 30 & Învoiala între moștenitorii familiei Hajdău & ” \\
\hline 2297 & 1817 & martie & 21 & Dania lui Teodor Ciurea dată lui Toader Hajdău ${ }^{673}$ & " \\
\hline 2298 & 1817 & mai & 1 & Măsura moșiei Cărstineștii, din județul Hotin & ” \\
\hline 2299 & 1826 & februarie & 17 & Împărțeala făcută între fiii lui I. Moșanu & $"$ \\
\hline 2300 & 1696 & decembrie & 30 & Zapisul lui Ion Bainschi pentru siliștea „Zanba” & $\begin{array}{l}\text { copie românească, cu } \\
\text { trad. rusească }\end{array}$ \\
\hline 2301 & 1762 & - & - & $\begin{array}{l}\text { Hotărîrea Judecătoriei din Cameneț Podolsc în } \\
\text { pricina lui Starșevschi }\end{array}$ & $\begin{array}{l}\text { trad. românească, orig. } \\
\text { latin }\end{array}$ \\
\hline 2302 & 1754 & octombrie & 3 & Cartea de judecată în pricina lui Grigorie Hajdău & $\begin{array}{l}\text { românesc, cu trad. } \\
\text { rusească }\end{array}$ \\
\hline 2303 & 1771 & - & - & $\begin{array}{l}\text { Hotărîrea Judecătoriei din Cameneț Podolsc în } \\
\text { pricina lui Victor Camenețchi }\end{array}$ & $"$ \\
\hline 2304 & 1701 & februarie & 13 & $\begin{array}{l}\text { Zapisul Anghelușei Stârcea pentru moșia } \\
\text { Tulbureni }\end{array}$ & românesc \\
\hline 2305 & 1815 & mai & 31 & $\begin{array}{l}\text { Perilipsis din condica Judecătoriei Movilăului, } \\
\text { gubernia Podolia }\end{array}$ & ” \\
\hline 2306 & 1773 & februarie & 1 & Hotărîrea Judecătoriei <din > Cameneț Podolsc & ” \\
\hline 2307 & 1655 & mai & 20 & $\begin{array}{l}\text { Copie. Zapisul Antimiei <și a surorii sale, Vasilca, } \\
\text { soția lui Toderașco> Jora pentru împărțeala făcută } \\
\text { între moștenitorii <lui Gânscă } 675\end{array}$ & ” \\
\hline 2308 & 1810 & septembrie & 5 & $\begin{array}{l}\text { Cartea Divanului cu privire la moșiile din județul } \\
\text { Hotin }\end{array}$ & ” \\
\hline 2309 & 1745 & mai & 29 & Împărțeala între moștenitorii lui Sandul Sturza & ” \\
\hline
\end{tabular}

\footnotetext{
${ }^{668}$ Boga (1928b), p. 140, nr. CXCII.

${ }^{669}$ Consiliul (Sfatul) Suprem al Basarabiei (Бессарабский Верховныцй Совет).

${ }^{670} \mathrm{Boga}$ (1928b), p. 119-120, nr. CLIX.

${ }^{671}$ Numele a fost citit în trei feluri: ,Juter”, „Jutcă” și „Junter”.

${ }^{672}$ Probabil satul Pânzărești, din ținutul Iași.

${ }^{673}$ Boga (1929a), p. 88-90, nr. CXV.

${ }^{674}$ Doc. T..Mold., X, p. 115-116, nr. 79.

${ }^{675}$ În text, greșit: „lui Jora”. Boga (1932a), p. 157, nr. XX.
} 


\begin{tabular}{|c|c|c|c|c|c|}
\hline 2310 & 1645 & august & 14 & Suret de pe carte lui Vasilie voievod dată lui „Colac” & $"$ \\
\hline 2311 & 1763 & ianuarie & 8 & Cartea de judecată în pricina lui Grigorie Hajdău & ” \\
\hline 2312 & - & - & - & Spița neamului Hajdău & ” \\
\hline 2313 & 1814 & august & 28 & Lista moșiilor familiei Calmuțchi & 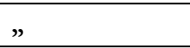 \\
\hline 2314 & 1615 & martie & 24 & Suret după împărțeala familiei Vartic ${ }^{676}$ & ” \\
\hline 2315 & 1643 & mai & 14 & Copie după zapisul Grapinei „Prodăneni” & " \\
\hline 2316 & 1809 & aprilie & 15 & $\begin{array}{l}\text { Mărturia moștenitorilor Sturzești pentru moșia din } \\
\text { Hotin }\end{array}$ & $"$ \\
\hline 2317 & 1676 & - & - & Extras din condicile judecătoriei leșești & ” \\
\hline 2318 & 1811 & aprilie & 12 & $\begin{array}{l}\text { Adresa Divanului către președintele Divanului } \\
\text { pentru moșiile din județul Hotin }\end{array}$ & $"$ \\
\hline 2319 & 1665 & mai & 27 & $\begin{array}{l}\text { Copie. Învoiala între moștenitorii familiei } \\
\text { Hajdău } 677\end{array}$ & $"$ \\
\hline 2320 & 1696 & decembrie & 30 & $\begin{array}{l}\text { Zapisul lui Ion Bainschi pentru siliștea Zelena, <din } \\
\text { ținutul Hotin> }\end{array}$ & copie \\
\hline 2321 & 1819 & februarie & 19 & Spița de neam a familiei Hajdău ${ }^{678}$ & românesc \\
\hline 2322 & 1818 & martie & 4 & Copie. Învoiala între Diacon și T. Hajdău & 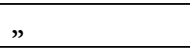 \\
\hline 2323 & - & - & - & Spița neamului Donici & rusesc \\
\hline 2324 & 1606 & aprilie & 6 & $\begin{array}{l}\text { Cartea lui Eremia Movilă voievod, dată lui Dimitrie } \\
<\text { Ponici }>^{679} \text {, pentru moșia Sficicouți, < ținutul } \\
\text { Soroca, precum și pentru alte sate }>680\end{array}$ & trad. rusească \\
\hline 2325 & 1621 & noiembrie & 3 & $\begin{array}{l}\text { Cartea lui Radul voievod, dată lui D. Donici, p. } \\
\text { satul Svițcăuțí }\end{array}$ & $"$ \\
\hline 2326 & 1635 & aprilie & 30 & $\begin{array}{l}\text { Cartea lui Vasilie voievod, dată lui D. Donici, p. } \\
\text { satul Svițcăuțí }^{682}\end{array}$ & $"$ \\
\hline 2327 & 1741 & ianuarie & 30 & $\begin{array}{l}\text { Cartea lui Grigorie Ghica voievod, dată logofătului } \\
\text { Buzilă, pentru moșia Costinești }\end{array}$ & $”$ \\
\hline 2328 & 1765 & februarie & 9 & $\begin{array}{l}\text { Cartea lui Grigorie Ghica voievod, dată lui } \\
\text { „Calestin”, pentru o parte din Zaluceni }\end{array}$ & $"$ \\
\hline 2329 & 1837 & februarie & 10 & $\begin{array}{l}\text { Învoiala între Negoiță Radu şi Teodor Ciure pentru } \\
\text { venitul moșiei }\end{array}$ & românesc \\
\hline 2330 & 1811 & martie & 22 & Învoiala între Teodor Ciure și familia Hajdău & $"$ \\
\hline 2331 & 1844 & iunie & 2 & $\begin{array}{l}\text { Certificatul Valeriei Hajdău privitor la niște lucruri } \\
\text { trecute pe la vama Sculeni }\end{array}$ & rusesc \\
\hline 2332 & 1817 & martie & 15 & Învoiala între familiile Hajdău, Diacon și Megevschi & românesc \\
\hline 2333 & 1812 & martie & 28 & Mărturia privitoare la statutul moșiei Cărstinești & ” \\
\hline 2334 & 1665 & februarie & 23 & $\begin{array}{l}\text { Copie. Cartea lui Dabija voievod pentru satul } \\
\text { satele: Ionășeni, „Debinești”, Dragomănești }\end{array}$ & $"$ \\
\hline 2335 & 1832 & septembrie & 6 & Mărturia cu privire la zestrea spătarului Ioniță Gane & " \\
\hline 2336 & 1817 & martie & 18 & Venitul moșiei Crâstinești, din județul Hotin & ” \\
\hline 2337 & 1817 & iunie & 16 & Adresa Pîrcălăbiei Hotin către Iordache Mărzac & ” \\
\hline 2338 & 1817 & iunie & 17 & Scrisoarea lui T. Ciure către Costache Chiruș & ” \\
\hline 2339 & 1842 & august & 23 & $\begin{array}{l}\text { Adeverința lui Gh. Ciomărtan pentru moșia } \\
\text { Cărstinești }\end{array}$ & ” \\
\hline 2340 & 1818 & februarie & 8 & Scrisoarea lui T. Ciure către Costache Chiruș & ” \\
\hline 2341 & - & - & - & $\begin{array}{l}\text { Socoteala banilor cheltuiți cu ocazia venirei } \\
\text { împăratului }\end{array}$ & ” \\
\hline
\end{tabular}

\footnotetext{
${ }^{676}$ Boga (1932a), p. 144-145, nr. IV (Vasile, fiul lui Gavrilaș Vartic, și sora sa, Antimia, soția lui Miron Barnovschi). ${ }^{677} \mathrm{MEF}, \mathrm{V}, \mathrm{p} .129-130$, nr. 50.

${ }^{678}$ Onea (1994), p. 89-92 (genealogia a fost descoperită în Fondul 220 de la Arhivele din Chișinău de Vasile Malanețchi și xeroxată de Flavius Solomon). Spița a fost publicată și de Constantinov \& Ciobanu (2017), p. 54-57, însă, chiar dacă „spița neamului Hâjdeu" apare în titlu, articolul vorbește despre altceva.

${ }^{679}$ În text, greșit: „Ponici”.

${ }^{680} \mathrm{Boga}$ (1929d), p. 4-5, nr. II; MEF, I, p. 212-214, nr. 91.

${ }^{681} \mathrm{MEF}$, III, p. 154-155, nr. 77.

${ }^{682} \mathrm{MEF}$, III, p. $323-324$, nr. 160.
} 


\begin{tabular}{l||l|l|l|l|l}
\hline 2342 & 1818 & februarie & 20 & Adeverința lui Iordache Dimitriu pentru 1.289 lei & ” \\
\hline 2343 & 1806 & august & 18 & $\begin{array}{l}\text { Diploma dată lui Grigore Turcovici prin care este } \\
\text { avansat la gradul de ștabs rotmistru }\end{array}$ & rusesc \\
\hline 2344 & 1834 & noiembrie & 19 & $\begin{array}{l}\text { Contract încheiat între Grigorie Irinopoleos și } \\
\text { Constantin „Gortopolo” pentru moșia Bogdănești }\end{array}$ & românesc \\
\hline 2345 & - & - & - & $\begin{array}{l}\text { Diverse foi volante rusești, contracte rusești și două } \\
\text { opise de diverse documente }\end{array}$ & ”, \\
\hline
\end{tabular}

Proces verbal

Încheiat, azi, 10 iulie 1926

Subsemnatul, Eugen Ionescu Dârzeu, Prim-Președinte al Tribunalului Lăpuşna, am primit documentele cuprinse în original, în opisul de față, și subsemnatul, Leon T. Boga, Director Regional al Arhivelor Statului, am luat în primire documentele cuprinse în opisul de faţă şi urmează a se păstra la Direcțiunea Regională a Arhivelor Statului din Chişinău.

Documentele cuprise în prezentul opis sînt cele găsite în ziua de 6 iunie 1926, în două lăzi și un geamantan, neinventariate, în podul Palatului de Justiţie, de subsemnatul Eugen Ionescu Dârzeu, PrimPreședinte al Tribunalului Lăpuşna.

Prim-Președinte

Director Regional 